\title{
Saturation of Impurity-Rich Phases in a Cerium-Substituted Pyrochlore-Rich Titanate Ceramic: Part 1. Experimental Results
}

F. J. Ryerson, B. Ebbinghaus, O. Kirkorian, R. VanKonynenburg U.S. Department of Energy

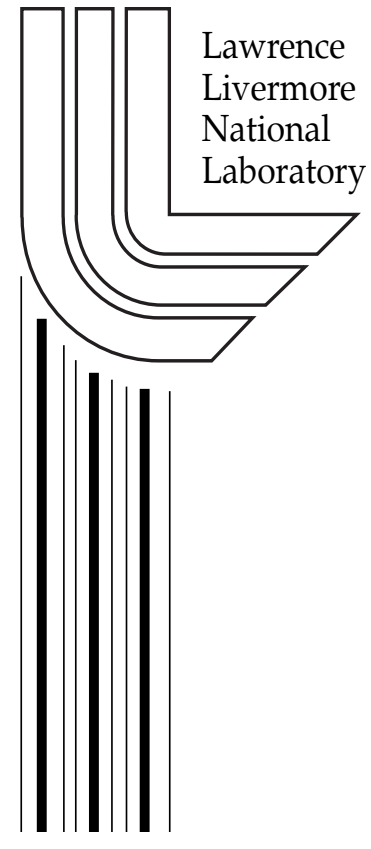

May 25, 2000 


\section{DISCLAIMER}

This document was prepared as an account of work sponsored by an agency of the United States Government. Neither the United States Government nor the University of California nor any of their employees, makes any warranty, express or implied, or assumes any legal liability or responsibility for the accuracy, completeness, or usefulness of any information, apparatus, product, or process disclosed, or represents that its use would not infringe privately owned rights. Reference herein to any specific commercial product, process, or service by trade name, trademark, manufacturer, or otherwise, does not necessarily constitute or imply its endorsement, recommendation, or favoring by the United States Government or the University of California. The views and opinions of authors expressed herein do not necessarily state or reflect those of the United States Government or the University of California, and shall not be used for advertising or product endorsement purposes.

This work was performed under the auspices of the U.S. Department of Energy by the University of California, Lawrence Livermore National Laboratory under Contract No. W-7405-Eng-48.

This report has been reproduced directly from the best available copy.

Available to DOE and DOE contractors from the Office of Scientific and Technical Information

P.O. Box 62, Oak Ridge, TN 37831

Prices available from (423) 576-8401

http:/ / apollo.osti.gov/bridge/

Available to the public from the National Technical Information Service

U.S. Department of Commerce 5285 Port Royal Rd., Springfield, VA 22161 http://www.ntis.gov/

OR Lawrence Livermore National Laboratory Technical Information Department's Digital Library http://www.llnl.gov/tid/Library.html 
Saturation of impurity-rich phases in a cerium-substituted pyrochlore-rich titanate ceramic:

Part 1. Experimental Results *

by

F.J. Ryerson ${ }^{1}$, Bartley Ebbinghaus ${ }^{2}$, Oscar Kirkorian ${ }^{2}$, Richard VanKonynenburg ${ }^{2}$,

1. Earth and Environmental Sciences

Lawrence Livermore National Laboratory

Livermore, CA 94550

2. Chemistry and Material Sciences

Lawrence Livermore National Laboratory

Livermore, CA 94550

ॠThis work was performed under the auspices of the U.S. Department of Energy by University of California Lawrence Livermore National Laboratory under contract No. W-7405-Eng-48 
Abstract. The saturation of impurity-rich accessory phases in a Ce-analog baseline ceramic formulation for the immobilization of excess plutonium has been tested by synthesizing an impurity-rich baseline compositions at $1300^{\circ} \mathrm{C} 1350^{\circ} \mathrm{C}$ and $1400^{\circ} \mathrm{C}$ in air. Impurity oxides are added at the $10 \mathrm{wt} \%$ level. The resulting phases assemblages are typically rich in pyrochlore, Hf-zirconolite (hafnolite), brannerite and rutile, but in many instances also contain an accessory mineral enriched in the impurity oxide. The concentration of that oxide in coexisting pyrochlore sets the saturation limit for solid solution of the component in question. In most cases, the accessory phase does not contain significant amounts of $\mathrm{Ce}, \mathrm{Gd}$ or $\mathrm{U}$. Exceptions are the stabilization of a Ca-lanthanide phosphate and a phosphate glass when $\mathrm{P}_{2} \mathrm{O}_{5}$ is added to the formulation. $\mathrm{P}_{2} \mathrm{O}_{5}$ addition is also very effective in reducing the modal amount of pyrochlore in the form relative to brannerite. Addition of the sodium-aluminosilicate, $\mathrm{NaAlSiO}_{4}$, also results in the formation of a grain boundary melt at run conditions, but the fate of this phase on cooling is not well determined. At temperatures above $1300^{\circ} \mathrm{C}$, addition of 10 wt $\% \mathrm{Fe}_{2} \mathrm{O}_{3}$ also leads to melting. Substitution of cations of different valences can also be associated with model-dependent changes in the oxidation state of uranium via charge transfer reactions. A set of simple components is suggested for the description of pyrochlores in both impurity-free and impurity-rich formulations.

\section{Introduction}

A primary goal of the Plutonium Immobilization Project is to determine the phase equilibria for the baseline ceramic formulation (Ebbinghaus et al. 1999) as a function of potential processing conditions and variations in chemistry. These variables will effect the partitioning of the various elements among the phases which constitute the wasteform, and may also lead to the formation of additional phases which may or may not include either plutonium or neutron absorbers. In a companion document, we considered the effect of changing oxidation state on the phase equilibria of cerium- and thorium-substituted analogs with and without alumina (Ryerson and Ebbinghaus, 2000). Here we assess the effects of potential wastestream impurities on the phase assemblage in a Ce-substituted analog.

The baseline formulation (Table 1) is designed to produce a pyrochlore of composition $\left(\mathrm{Ca}_{0.89} \mathrm{Gd}_{0.22} \mathrm{Hf}_{0.23} \mathrm{U}_{0.44} \mathrm{Pu}_{0.22}\right) \mathrm{Ti}_{2} \mathrm{O}_{7}$, and rutile of composition $\left(\mathrm{Hf}_{0.2} \mathrm{Ti}_{0.8}\right) \mathrm{O}_{2}$. The target phase 
assemblage comprises $95 \mathrm{wt} \%$ pyrochlore and $5 \mathrm{wt} \%$ rutile. While plutonium is the element of major interest, the formulation also contains hafnium, gadolinium and uranium to act as both neutron absorbers in the wasteform itself, or in possible dissolution products (Ebbinghaus et al, 1999). When synthesized under relatively oxidizing conditions (air or argon) in the temperature range $1300-1400^{\circ} \mathrm{C}$ both the Pu-bearing and Ce-analog materials have been shown to crystallize a hafnium-rich analog of zirconolite, $\mathrm{CaHfTi}_{2} \mathrm{O}_{7}$ (referred to here as "hafnolite"), and brannerite, (nominally, $\mathrm{UTi}_{2} \mathrm{O}_{6}$ ) in addition to pyrochlore and rutile. The appearance of these phases may be attributed to variations in the oxidation states of cerium, plutionium and uranium, as well as to the presence of additional impurity elements that may stabilize these phases.

Fortunately, both zirconolite/hafnolite and brannerite are known to be chemically durable, and their appearance in the wasteform may not have deleterious effects upon it ability to immobilize plutonium (cf., Bourcier et al., 1999). However, potential waste streams can contain a broad array of chemical constituents, and the ability of a pyrochlorebrannerite-hafnolite-rutile assemblage to incorporate other elements without the formation of additional phases (subsequently referred to as "accessory phases") depends upon the solubilities of such elements in pyrochlore, brannerite, hafnolite, and rutile. These solubility limits can be determined by measuring the amount of a particular element in each of the primary phases when they coexist with an accessory phase in which the impurity element can be considered as essential structural constituent. For instance, the solubility of nickel oxide in pyrochlore in a NiO-rich composition is fixed when pyrochlore coexists $\mathrm{NiTiO}_{3}$. Here we have imposed the saturation of a number of such accessory phases on a Ce-analog of the baseline composition by adding $\sim 10 \mathrm{wt} \%$ of the impurity oxide to the composition (Table 1). 
Table 1. "As-made" starting compositions

\begin{tabular}{|c|c|c|c|c|c|c|c|c|c|c|c|c|c|}
\hline & M1 & M2 & M3 & M4 & M5 & M6 & M7 & M8 & M9 & M10 & M11 & $\mathrm{M} 12$ & M13 \\
\hline $\mathrm{Na}_{2} \mathrm{O}$ & 0.00 & 0.00 & 0.00 & 0.00 & 0.00 & 0.00 & 0.00 & 0.00 & 0.00 & 0.00 & 0.00 & 0.00 & 0.00 \\
\hline $\mathrm{CaO}$ & 10.48 & 9.34 & 9.32 & 9.33 & 10.33 & 9.32 & 9.32 & 9.93 & 19.36 & 9.30 & 9.30 & 9.51 & 13.12 \\
\hline $\mathrm{TiO}_{2}$ & 36.90 & 33.59 & 33.60 & 33.65 & 37.45 & 33.57 & 33.55 & 35.77 & 33.58 & 33.63 & 33.46 & 34.25 & 34.17 \\
\hline $\mathrm{HfO}_{2}$ & 11.20 & 10.06 & 10.10 & 9.95 & 11.10 & 10.06 & 10.02 & 10.73 & 10.07 & 10.01 & 9.94 & 10.20 & 10.20 \\
\hline $\mathrm{Gd}_{2} \mathrm{O}_{3}$ & 8.33 & 7.44 & 7.46 & 7.47 & 8.28 & 7.45 & 7.52 & 7.93 & 7.48 & 7.47 & 7.44 & 7.61 & 7.60 \\
\hline $\mathrm{UO}_{2}$ & 24.85 & 22.12 & 22.23 & 22.19 & 24.61 & 22.17 & 22.24 & 23.63 & 22.14 & 22.19 & 22.11 & 22.63 & 22.62 \\
\hline $\mathrm{CeO}_{2}$ & 8.23 & 7.41 & 7.37 & 7.39 & 8.21 & 7.37 & 7.35 & 0.00 & 7.38 & 7.37 & 7.36 & 7.54 & 7.50 \\
\hline $\mathrm{P}_{2} \mathrm{O}_{5}$ & 0.00 & 10.05 & 0.00 & 0.00 & 0.00 & 0.00 & 0.00 & 0.00 & 0.00 & 0.00 & 0.00 & 0.00 & 0.00 \\
\hline $\mathrm{CaF}_{2}$ & 0.00 & 0.00 & 9.92 & 0.00 & 0.00 & 0.00 & 0.00 & 0.00 & 0.00 & 0.00 & 0.00 & 0.00 & 0.00 \\
\hline $\mathrm{Fe}_{2} \mathrm{O}_{3}$ & 0.00 & 0.00 & 0.00 & 10.02 & 0.00 & 0.00 & 0.00 & 0.00 & 0.00 & 0.00 & 4.54 & 0.00 & 0.00 \\
\hline $\mathrm{MgO}$ & 0.00 & 0.00 & 0.00 & 0.00 & 0.00 & 10.05 & 0.00 & 0.00 & 0.00 & 0.00 & 0.00 & 2.88 & 0.00 \\
\hline $\mathrm{Al}_{2} \mathrm{O}_{3}$ & 0.00 & 0.00 & 0.00 & 0.00 & 0.00 & 0.00 & 10.00 & 0.00 & 0.00 & 0.00 & 5.86 & 5.38 & 4.79 \\
\hline $\mathrm{SiO}_{2}$ & 0.00 & 0.00 & 0.00 & 0.00 & 0.00 & 0.00 & 0.00 & 0.00 & 0.00 & 10.01 & 0.00 & 0.00 & 0.00 \\
\hline $\mathrm{NiO}$ & 0.00 & 0.00 & 0.00 & 0.00 & 0.00 & 0.00 & 0.00 & 0.00 & 0.00 & 0.00 & 0.00 & 0.00 & 0.00 \\
\hline $\mathrm{Ga}_{2} \mathrm{O}_{3}$ & 0.00 & 0.00 & 0.00 & 0.00 & 0.00 & 0.00 & 0.00 & 0.00 & 0.00 & 0.00 & 0.00 & 0.00 & 0.00 \\
\hline $\mathrm{Cr}_{2} \mathrm{O}_{3}$ & 0.00 & 0.00 & 0.00 & 0.00 & 0.00 & 0.00 & 0.00 & 0.00 & 0.00 & 0.00 & 0.00 & 0.00 & 0.00 \\
\hline $\mathrm{MnO}_{2}$ & 0.00 & 0.00 & 0.00 & 0.00 & 0.00 & 0.00 & 0.00 & 0.00 & 0.00 & 0.00 & 0.00 & 0.00 & 0.00 \\
\hline $\mathrm{CuO}$ & 0.00 & 0.00 & 0.00 & 0.00 & 0.00 & 0.00 & 0.00 & 0.00 & 0.00 & 0.00 & 0.00 & 0.00 & 0.00 \\
\hline $\mathrm{ZnO}$ & 0.00 & 0.00 & 0.00 & 0.00 & 0.00 & 0.00 & 0.00 & 0.00 & 0.00 & 0.00 & 0.00 & 0.00 & 0.00 \\
\hline $\mathrm{MoO}_{3}$ & 0.00 & 0.00 & 0.00 & 0.00 & 0.00 & 0.00 & 0.00 & 0.00 & 0.00 & 0.00 & 0.00 & 0.00 & 0.00 \\
\hline $\mathrm{WO}_{3}$ & 0.00 & 0.00 & 0.00 & 0.00 & 0.00 & 0.00 & 0.00 & 0.00 & 0.00 & 0.00 & 0.00 & 0.00 & 0.00 \\
\hline $\mathrm{Nb} 2 \mathrm{O}_{5}$ & 0.00 & 0.00 & 0.00 & 0.00 & 0.00 & 0.00 & 0.00 & 0.00 & 0.00 & 0.00 & 0.00 & 0.00 & 0.00 \\
\hline $\mathrm{ThO}_{2}$ & 0.00 & 0.00 & 0.00 & 0.00 & 0.00 & 0.00 & 0.00 & 12.02 & 0.00 & 0.00 & 0.00 & 0.00 & 0.00 \\
\hline Total & 100.00 & 100.00 & 100.00 & 100.00 & 100.00 & 100.00 & 100.00 & 100.00 & 100.00 & 100.00 & 100.00 & 100.00 & 100.00 \\
\hline
\end{tabular}


Table 1 (cont.). "As-made" starting compositions

\begin{tabular}{|c|c|c|c|c|c|c|c|c|c|c|c|c|}
\hline & M14 & M15 & M16 & M17 & M18 & M19 & M20 & M21 & $\mathrm{M} 22$ & P229 & $\mathrm{P} 232$ & P243 \\
\hline $\mathrm{Na}_{2} \mathrm{O}$ & 0.00 & 2.31 & 4.50 & 0.00 & 0.00 & 0.00 & 0.00 & 0.00 & 0.00 & 0.00 & 0.00 & 0.00 \\
\hline $\mathrm{CaO}$ & 9.66 & 9.39 & 8.46 & 9.35 & 9.32 & 9.32 & 9.32 & 9.31 & 9.34 & 11.56 & 10.85 & 10.65 \\
\hline $\mathrm{TiO}_{2}$ & 34.34 & 33.96 & 30.40 & 33.52 & 33.54 & 33.55 & 33.56 & 33.63 & 33.54 & 32.49 & 30.51 & 29.94 \\
\hline $\mathrm{HfO}_{2}$ & 10.18 & 10.12 & 9.10 & 10.01 & 10.02 & 10.11 & 10.01 & 10.08 & 10.03 & 9.65 & 9.07 & 8.90 \\
\hline $\mathrm{Gd}_{2} \mathrm{O}_{3}$ & 15.61 & 7.51 & 6.76 & 7.48 & 7.43 & 7.46 & 7.45 & 7.44 & 7.44 & 7.24 & 6.80 & 6.68 \\
\hline $\mathrm{UO}_{2}$ & 22.68 & 22.33 & 20.11 & 22.22 & 22.19 & 22.24 & 22.23 & 22.22 & 22.23 & 21.57 & 20.26 & 27.89 \\
\hline $\mathrm{CeO}_{2}$ & 7.53 & 7.45 & 6.68 & 7.36 & 7.37 & 7.36 & 7.36 & 7.35 & 7.37 & 6.88 & 6.46 & 6.34 \\
\hline $\mathrm{P}_{2} \mathrm{O}_{5}$ & 0.00 & 0.00 & 0.00 & 0.00 & 0.00 & 0.00 & 0.00 & 0.00 & 0.00 & 0.00 & 0.00 & 0.00 \\
\hline $\mathrm{CaF}_{2}$ & 0.00 & 0.00 & 0.00 & 0.00 & 0.00 & 0.00 & 0.00 & 0.00 & 0.00 & 0.00 & 0.00 & 0.00 \\
\hline $\mathrm{Fe}_{2} \mathrm{O}_{3}$ & 0.00 & 0.00 & 0.00 & 0.00 & 0.00 & 0.00 & 0.00 & 0.00 & 0.00 & 0.00 & 0.00 & 0.00 \\
\hline $\mathrm{MgO}$ & 0.00 & 0.00 & 0.00 & 0.00 & 0.00 & 0.00 & 0.00 & 0.00 & 0.00 & 0.00 & 0.00 & 0.00 \\
\hline $\mathrm{Al}_{2} \mathrm{O}_{3}$ & 0.00 & 2.61 & 5.31 & 0.00 & 0.00 & 0.00 & 0.00 & 0.00 & 0.00 & 0.00 & 0.00 & 0.00 \\
\hline $\mathrm{SiO}_{2}$ & 0.00 & 4.32 & 8.68 & 0.00 & 0.00 & 0.00 & 0.00 & 0.00 & 0.00 & 0.00 & 0.00 & 0.00 \\
\hline $\mathrm{NiO}$ & 0.00 & 0.00 & 0.00 & 10.05 & 0.00 & 0.00 & 0.00 & 0.00 & 0.00 & 0.00 & 0.00 & 0.00 \\
\hline $\mathrm{Ga}_{2} \mathrm{O}_{3}$ & 0.00 & 0.00 & 0.00 & 0.00 & 0.00 & 9.97 & 0.00 & 0.00 & 0.00 & 0.00 & 0.00 & 0.00 \\
\hline $\mathrm{Cr}_{2} \mathrm{O}_{3}$ & 0.00 & 0.00 & 0.00 & 0.00 & 10.13 & 0.00 & 0.00 & 0.00 & 0.00 & 0.00 & 0.00 & 0.00 \\
\hline $\mathrm{MnO}_{2}$ & 0.00 & 0.00 & 0.00 & 0.00 & 0.00 & 0.00 & 10.08 & 0.00 & 0.00 & 0.00 & 0.00 & 0.00 \\
\hline $\mathrm{CuO}$ & 0.00 & 0.00 & 0.00 & 0.00 & 0.00 & 0.00 & 0.00 & 9.99 & 0.00 & 0.00 & 0.00 & 0.00 \\
\hline $\mathrm{ZnO}$ & 0.00 & 0.00 & 0.00 & 0.00 & 0.00 & 0.00 & 0.00 & 0.00 & 10.05 & 0.00 & 0.00 & 0.00 \\
\hline $\mathrm{MoO}_{3}$ & 0.00 & 0.00 & 0.00 & 0.00 & 0.00 & 0.00 & 0.00 & 0.00 & 0.00 & 10.61 & 0.00 & 0.00 \\
\hline $\mathrm{WO}_{3}$ & 0.00 & 0.00 & 0.00 & 0.00 & 0.00 & 0.00 & 0.00 & 0.00 & 0.00 & 0.00 & 16.05 & 0.00 \\
\hline $\mathrm{Nb}_{2} \mathrm{O}_{5}$ & 0.00 & 0.00 & 0.00 & 0.00 & 0.00 & 0.00 & 0.00 & 0.00 & 0.00 & 0.00 & 0.00 & 9.61 \\
\hline $\mathrm{ThO}_{2}$ & 0.00 & 0.00 & 0.00 & 0.00 & 0.00 & 0.00 & 0.00 & 0.00 & 0.00 & 0.00 & 0.00 & 0.00 \\
\hline Total & 100.00 & 100.00 & 100.00 & 100.00 & 100.00 & 100.00 & 100.00 & 100.00 & 100.00 & 100.00 & 100.00 & 100.00 \\
\hline
\end{tabular}




\section{Starting materials and experimental methods}

The goal of this investigation was to assess the effects of impurities in the waste stream on the phase equilibria of the baseline composition. This allows us to make relatively small batches, 1-2 g, of starting materials from mixtures of hydroxides, nitrates, hydratednitrates, carbonates, ammoniates and oxides (Appendix A). As many of the starting materials were extremely hygroscopic, we determined the useful oxide yield of each reagent by loss on ignition. Starting materials were ground by hand under ethanol in an alumina mortar and pestle. The resulting slurry was dried under a heat lamp producing a paste; due to the hygroscopic nature of the starting materials, a fully dry powder was never obtained at this stage of the preparation procedure. The paste was then transferred to a Pt crucible and calcined in air at $1000^{\circ} \mathrm{C}$ for at least 3 hours. This calcine was then reground by hand under ethanol in an alumina mortar and pestle prior to the addition of a polyvinyl alcohol solution to act as a binder. The calcine-polyvinyl alcohol slurry was dried under a heat lamp and then ground dry in an alumina mortar and pestle to obtain a free-flowing powder. Individual samples were hand-pressed in a stainless steel die and piston to produce disks approximately $2 \mathrm{~mm}$ thick, with an outside diameter of $<5 \mathrm{~mm}$, weighing $\sim 50 \mathrm{mg}$.

A bottom-loading Deltech furnace was used to anneal samples equilibrated in air. Samples were loaded in open Pt crucibles that were then placed on the lower platen of the furnace and hydraulically lifted into the furnace that was already at run temperature. Temperature was monitored using a Pt-Rh thermocouple placed within $5 \mathrm{~mm}$ of the sample. Samples reached run conditions within 2-4 minutes after insertion, and run duration was always in excess of 24 hours. Runs were quenched by lowering the platen and removing the crucibles that then cooled in air, reaching room temperature in less than five minutes. 


\section{Sample characterization}

The sintered disks were mounted in epoxy and then polished with alumina grits prior to final polishing with colloidal silica. The polished mounts were then carbon coated for SEM and electron probe analysis. Compositional analysis was performed on a JEOL-733 electron probe using wavelength dispersive analysis. The probe was operated at an accelerating voltage of $15 \mathrm{KV}$ with a beam current (measured in a Faraday cup embedded in the standard holder) of 5-100 na; lower currents were used on beam sensitive materials such as silica glass. X-ray intensities were reduced to oxide concentrations using the ZAF method as revised by Armstrong et al. (1995). The standards used in these analyses are given in Appendix B. Two notable x-ray interferences were observed. The $\mathrm{Ce}_{\mathrm{L} \beta 1}$ line interferes with the $\mathrm{Gd}_{\mathrm{L \alpha 1}}$ requiring the use of the $\mathrm{Gd}_{\mathrm{L} \beta 1}$ line, and in the Th-bearing samples, the $T h_{M \beta 1}$ interferes with the $U_{M \alpha 1-1}$ requiring use of the $U_{M \beta 1}$ line.

\section{Results}

In many of the experiments presented here, the addition of $10 \mathrm{wt} \%$ of a waste stream impurity oxide resulted in the formation of an accessory phase coupled with limited solution of the impurity element in the pyrochlore-brannerite-hafnolite-rutile phase assemblage (Table 2). We have divided the elements into two groups depending upon whether there is "appreciable" dissolution of the impurity element in pyrochlore. Weight fractions of phases in runs performed at $1350^{\circ} \mathrm{C}$ were determined by linear regression of

the average phase compositions and the "as-made" bulk compositions of the samples (Table 3). 
Table 2. Run Results

\begin{tabular}{|c|c|c|c|c|}
\hline Run \# & $\begin{array}{c}\text { Starting } \\
\text { Composition } \\
\end{array}$ & Variation & $\mathrm{T}(\mathrm{C})$ & Phases \\
\hline $1 / 1$ & M1 & $\mathrm{Hf}-\mathrm{Ce}-\mathrm{U}$ & 1300 & pyr, brn, rut \\
\hline $1 / 2$ & M1 & $\mathrm{Hf}-\mathrm{Ce}-\mathrm{U}$ & 1400 & pyr, brn, rut \\
\hline $1 / 3$ & M1 & $\mathrm{Hf}-\mathrm{Ce}-\mathrm{U}$ & 1350 & pyr, rut \\
\hline $2 / 1$ & M2 & $\mathrm{Hf}-\mathrm{Ce}-\mathrm{U}+\mathrm{P}$ & 1300 & brn, rut, CLP, P-glass \\
\hline $2 / 2$ & M2 & $\mathrm{Hf}-\mathrm{Ce}-\mathrm{U}+\mathrm{P}$ & 1400 & brn, rut, P-glass \\
\hline $2 / 3$ & M2 & Hf-Ce-U + P & 1350 & brn, rut, CLP, P-glass \\
\hline $3 / 1$ & M3 & $\mathrm{Hf}-\mathrm{Ce}-\mathrm{U}+\mathrm{CaF}_{2}$ & 1300 & pyr, pv, hfn \\
\hline $3 / 2$ & M3 & $\mathrm{Hf}-\mathrm{Ce}-\mathrm{U}+\mathrm{CaF}_{2}$ & 1400 & pyr, pv \\
\hline $3 / 3$ & M3 & $\mathrm{Hf}-\mathrm{Ce}-\mathrm{U}+\mathrm{CaF}_{2}$ & 1350 & pyr, pv \\
\hline $4 / 1$ & M4 & $\mathrm{Hf}-\mathrm{Ce}-\mathrm{U}+\mathrm{Fe}_{2} \mathrm{O}_{3}$ & 1300 & pyr, brn, hfn, ilm \\
\hline $4 / 2$ & M4 & $\mathrm{Hf}-\mathrm{Ce}-\mathrm{U}+\mathrm{Fe}_{2} \mathrm{O}_{3}$ & 1400 & melted \\
\hline $4 / 3$ & M4 & $\mathrm{Hf}-\mathrm{Ce}-\mathrm{U}+\mathrm{Fe}_{2} \mathrm{O}_{3}$ & 1350 & melted \\
\hline $5 / 1$ & M5 & Hf-Ce-U & 1300 & pyr, brn, rut \\
\hline $5 / 2$ & M5 & Hf-Ce-U & 1400 & pyr, brn, rut \\
\hline $5 / 3$ & M5 & $\mathrm{Hf}-\mathrm{Ce}-\mathrm{U}$ & 1350 & pyr, brn, rut \\
\hline $6 / 1$ & M6 & $\mathrm{Hf}-\mathrm{Ce}-\mathrm{U}+\mathrm{MgO}$ & 1300 & pyr, hfn, pv, MgTi-1 \\
\hline $6 / 2$ & M6 & $\mathrm{Hf}-\mathrm{Ce}-\mathrm{U}+\mathrm{MgO}$ & 1400 & pyr, pv, MgTi-1, MgTi-2 \\
\hline $6 / 3$ & M6 & $\mathrm{Hf}-\mathrm{Ce}-\mathrm{U}+\mathrm{MgO}$ & 1350 & pyr, pv, MgTi-1, MgTi-2 \\
\hline $7 / 1$ & M7 & $\mathrm{Hf}-\mathrm{Ce}-\mathrm{U}+\mathrm{Al}_{2} \mathrm{O}_{3}$ & 1300 & pyr, brn, hfn, cor, rut \\
\hline $7 / 2$ & M7 & $\mathrm{Hf}-\mathrm{Ce}-\mathrm{U}+\mathrm{Al}_{2} \mathrm{O}_{3}$ & 1400 & pyr, brn, hfn, psd \\
\hline $7 / 3$ & M7 & $\mathrm{Hf}-\mathrm{Ce}-\mathrm{U}+\mathrm{Al}_{2} \mathrm{O}_{3}$ & 1350 & pyr, brn, hfn, psb \\
\hline $8 / 1$ & M8 & Hf-Th-U & 1300 & pyr, brn, rut \\
\hline $8 / 2$ & M8 & Hf-Th-U & 1400 & pyr, brn, rut \\
\hline $8 / 3$ & M8 & Hf-Th-U & 1350 & pyr, brn, rut \\
\hline $9 / 1$ & M9 & $\mathrm{Hf}-\mathrm{Ce}-\mathrm{U}+\mathrm{CaO}$ & 1300 & pyr, pv \\
\hline $9 / 2$ & M9 & $\mathrm{Hf}-\mathrm{Ce}-\mathrm{U}+\mathrm{CaO}$ & 1400 & pyr, pv \\
\hline $9 / 3$ & M9 & $\mathrm{Hf}-\mathrm{Ce}-\mathrm{U}+\mathrm{CaO}$ & 1350 & pyr, pv \\
\hline $10 / 1$ & M10 & $\mathrm{Hf}-\mathrm{Ce}-\mathrm{U}+10 \% \mathrm{SiO}_{2}$ & 1300 & brn, rut, glass \\
\hline $10 / 2$ & M10 & $\mathrm{Hf}-\mathrm{Ce}-\mathrm{U}+10 \% \mathrm{SiO}_{2}$ & 1350 & brn, hfO ${ }_{2}$, glass \\
\hline $11 / 2$ & M11 & $\mathrm{Hf}-\mathrm{Ce}-\mathrm{U}+10 \% \mathrm{FeAl}_{2} \mathrm{O}_{4}$ & 1300 & py, hfn, psd \\
\hline $11 / 1$ & M11 & $\mathrm{Hf}-\mathrm{Ce}-\mathrm{U}+10 \% \mathrm{FeAl}_{2} \mathrm{O}_{4}$ & 1350 & py, hfn, psd \\
\hline $11 / 3$ & M11 & $\mathrm{Hf}-\mathrm{Ce}-\mathrm{U}+10 \% \mathrm{FeAl}_{2} \mathrm{O}_{4}$ & 1400 & melted \\
\hline
\end{tabular}

All runs performed in air.

$\mathrm{Py}=$ pyrochlore, brn=brannerite, ru=rutile, $\mathrm{hfn}=$ hafnolite, $\mathrm{pv}=$ perovskite, $\mathrm{CLP}=$ calciumlanthanide phosphate, $\mathrm{P}$-glass=phosphorus-rich glass, $\mathrm{MgTi}-1=\mathrm{MgTiO}_{3}$, MgTi-2 $=\mathrm{Mg}_{2} \mathrm{TiO}_{4}, \mathrm{psb}=$ psuedobrookite, cor=corundum, $\mathrm{CTA}=$ calcium-lanthanide titanium aluminate, $\mathrm{Ga}="$ galonite", $\operatorname{croxy}=\mathrm{Cr}_{\mathrm{x}} \mathrm{O}_{\mathrm{y}}, \mathrm{Ni}-\mathrm{Ti}=\mathrm{NiTiO}_{3}, \mathrm{Ca}-\mathrm{Mo}=$ calcium molybdate, $\mathrm{Ca}-\mathrm{W}=$ calcium tungstate 
Table 2 (cont.). Run Results

\begin{tabular}{|c|c|c|c|c|}
\hline Run \# & $\begin{array}{c}\text { Starting } \\
\text { Composition }\end{array}$ & Variation & $\mathrm{T}(\mathrm{C})$ & Phases \\
\hline $12 / 2$ & M12 & $\mathrm{Hf}-\mathrm{Ce}-\mathrm{U}+10 \% \mathrm{MgAl}_{2} \mathrm{O}_{4}$ & 1300 & py, hfn, psb \\
\hline $12 / 1$ & M12 & $\mathrm{Hf}-\mathrm{Ce}-\mathrm{U}+10 \% \mathrm{MgAl}_{2} \mathrm{O}_{4}$ & 1350 & py, psb \\
\hline $12 / 3$ & M12 & $\mathrm{Hf}-\mathrm{Ce}-\mathrm{U}+10 \% \mathrm{MgAl}_{2} \mathrm{O}_{4}$ & 1400 & melted \\
\hline $13 / 2$ & M13 & $\mathrm{Hf}-\mathrm{Ce}-\mathrm{U}+10 \% \mathrm{CaAl}_{2} \mathrm{O}_{4}$ & 1300 & py, hfn, CTA, cor, rut \\
\hline $13 / 1$ & M13 & $\mathrm{Hf}-\mathrm{Ce}-\mathrm{U}+10 \% \mathrm{CaAl}_{2} \mathrm{O}_{4}$ & 1350 & py, hfn,CTA \\
\hline $13 / 3$ & M13 & $\mathrm{Hf}-\mathrm{Ce}-\mathrm{U}+10 \% \mathrm{CaAl}_{2} \mathrm{O}_{4}$ & 1400 & py, hfn,CTA \\
\hline $14 / 2$ & M14 & $\mathrm{Hf}-\mathrm{Ce}-\mathrm{U}+10 \% \mathrm{Gd}_{2} \mathrm{O}_{3}$ & 1300 & py, brn, rut \\
\hline $14 / 1$ & M14 & $\mathrm{Hf}-\mathrm{Ce}-\mathrm{U}+10 \% \mathrm{Gd}_{2} \mathrm{O}_{3}$ & 1350 & py, brn, rut \\
\hline $14 / 3$ & M14 & $\mathrm{Hf}-\mathrm{Ce}-\mathrm{U}+10 \% \mathrm{Gd}_{2} \mathrm{O}_{3}$ & 1400 & py, brn, rut \\
\hline $15 / 2$ & M15 & $\mathrm{Hf}-\mathrm{Ce}-\mathrm{U}+10 \% \mathrm{NaAlSiO}_{4}$ & 1300 & py, hfn, rut, glass \\
\hline $15 / 1$ & M15 & $\mathrm{Hf}-\mathrm{Ce}-\mathrm{U}+10 \% \mathrm{NaAlSiO}$ & 1350 & py, hfn, glass \\
\hline $16 / 2$ & M16 & Hf-Ce-U +20\% NaAlSiO & 1300 & py, hfn, qlass \\
\hline $16 / 1$ & M16 & Hf-Ce-U $+20 \%$ NaAlSiO & 1350 & py, hfn, qlass \\
\hline $17 / 2$ & M17 & $\mathrm{Hf}-\mathrm{Ce}-\mathrm{U}+10 \% \mathrm{NiO}$ & 1300 & py, hfn, Ni-Pv \\
\hline $17 / 1$ & M17 & $\mathrm{Hf}-\mathrm{Ce}-\mathrm{U}+10 \% \mathrm{NiO}$ & 1350 & py, hfn, Ni-Pv \\
\hline $17 / 3$ & M17 & $\mathrm{Hf}-\mathrm{Ce}-\mathrm{U}+10 \% \mathrm{NiO}$ & 1400 & melted \\
\hline $18 / 2$ & M18 & $\mathrm{Hf}-\mathrm{Ce}-\mathrm{U}+10 \% \mathrm{Cr}_{2} \mathrm{O}_{3}$ & 1300 & py, hfn, rut, crxoy \\
\hline $18 / 1$ & M18 & $\mathrm{Hf}-\mathrm{Ce}-\mathrm{U}+10 \% \mathrm{Cr}_{2} \mathrm{O}_{3}$ & 1350 & py, hfn, rut, crxoy \\
\hline $18 / 3$ & M18 & $\mathrm{Hf}-\mathrm{Ce}-\mathrm{U}+10 \% \mathrm{Cr}_{2} \mathrm{O}_{3}$ & 1400 & py, hfn, rut, crxoy \\
\hline $19 / 2$ & M19 & Hf-Ce-U $+10 \% \mathrm{Ga}_{2} \mathrm{O}_{3}$ & 1300 & py, hfn, Ga \\
\hline $19 / 1$ & M19 & $\mathrm{Hf}-\mathrm{Ce}-\mathrm{U}+10 \% \mathrm{Ga}_{2} \mathrm{O}_{3}$ & 1350 & py, hfn, Ga \\
\hline $20 / 2$ & M20 & $\mathrm{Hf}-\mathrm{Ce}-\mathrm{U}+10 \% \mathrm{MnO}_{2}$ & 1300 & py, pv \\
\hline $20 / 1$ & M20 & $\mathrm{Hf}-\mathrm{Ce}-\mathrm{U}+10 \% \mathrm{MnO}_{2}$ & 1350 & py, pv \\
\hline $20 / 3$ & M20 & $\mathrm{Hf}-\mathrm{Ce}-\mathrm{U}+10 \% \mathrm{MnO}_{2}$ & 1400 & py, pv \\
\hline $21 / 2$ & M21 & $\mathrm{Hf}-\mathrm{Ce}-\mathrm{U}+10 \% \mathrm{CuO}$ & 1300 & py, rut \\
\hline $21 / 1$ & M21 & $\mathrm{Hf}-\mathrm{Ce}-\mathrm{U}+10 \% \mathrm{CuO}$ & 1350 & py, rut \\
\hline $22 / 2$ & M22 & $\mathrm{Hf}-\mathrm{Ce}-\mathrm{U}+10 \% \mathrm{ZnO}$ & 1300 & py, hfn \\
\hline $22 / 1$ & M22 & $\mathrm{Hf}-\mathrm{Ce}-\mathrm{U}+10 \% \mathrm{ZnO}$ & 1350 & py, rut \\
\hline P229 & P229 & $\mathrm{Hf}-\mathrm{Ce}-\mathrm{U}+10 \% \mathrm{MoO}_{3}$ & 1350 & py, brn, Ca-Mo \\
\hline $\mathrm{P} 232$ & $\mathrm{P} 232$ & Hf-Ce- $U+10 \% \mathrm{WO}_{3}$ & 1350 & py, brn, rut, Ca-W \\
\hline P243 & P243 & $\mathrm{Hf}-\mathrm{Ce}-\mathrm{U}+10 \% \mathrm{Nb}_{2} \mathrm{O}_{5}$ & 1350 & py, brn, rut \\
\hline
\end{tabular}

All runs performed in air.

Py=pyrochlore, brn=brannerite, $r u=r u t i l e, h f n=h a f n o l i t e, p v=$ perovskite, $C L P=$ calciumlanthanide phosphate, $\mathrm{P}$-glass=phosphorus-rich glass, $\mathrm{MgTi}-1=\mathrm{MgTiO}_{3}$, MgTi-2= $\mathrm{Mg}_{2} \mathrm{TiO}_{4}$, psb=psuedobrookite, cor=corundum, CTA=calcium-lanthanide titanium aluminate, $\mathrm{Ga}="$ galonite", $\mathrm{croxy}=\mathrm{Cr}_{\mathrm{x}} \mathrm{O}_{\mathrm{y}}, \mathrm{Ni}-\mathrm{Ti}=\mathrm{NiTiO}_{3}, \mathrm{Ca}-\mathrm{Mo}=$ calcium molybdate, $\mathrm{Ca}-\mathrm{W}=$ calcium tungstate 
Table 3. Phase fractions based on linear regression of bulk and phase compositions

\begin{tabular}{|c|c|c|c|c|c|c|c|c|c|c|c|c|c|c|c|c|}
\hline & $1 / 3$ & \pm & $2 / 3$ & \pm & $3 / 3$ & \pm & $4 / 1$ & \pm & $5 / 3$ & \pm & $6 / 3$ & \pm & $7 / 3$ & \pm & $8 / 3$ & \pm \\
\hline Py & 1.049 & 0.074 & 0.659 & 0.037 & 0.918 & 0.059 & 0.418 & 0.079 & 0.79 & 0.035 & 0.813 & 0.028 & 0.522 & 0.207 & 0.733 & 0.036 \\
\hline $\mathrm{Brn}$ & 0 & 0 & 0 & 0 & 0 & 0 & 0.066 & 0.043 & 0.187 & 0.031 & 0 & 0 & 0.187 & 0.156 & 0.282 & 0.034 \\
\hline $\mathrm{Hfn}$ & 0 & 0 & 0 & 0 & 0 & 0 & 0.41 & 0.117 & 0 & 0 & 0 & 0 & 0.142 & 0.091 & 0 & 0 \\
\hline $\mathrm{Ru}$ & 0.021 & 0.041 & 0.105 & 0.026 & 0 & 0 & 0 & 0 & 0.052 & 0.01 & 0 & 0 & 0 & 0 & -0.004 & 0.013 \\
\hline $\mathrm{Pv}$ & 0 & 0 & 0 & 0 & 0.09 & 0.044 & 0 & 0 & 0 & 0 & -0.012 & 0.029 & 0 & 0 & 0 & 0 \\
\hline CTA & 0 & 0 & 0 & 0 & 0 & 0 & 0 & 0 & 0 & 0 & 0 & 0 & 0 & 0 & 0 & 0 \\
\hline $\mathrm{MgTiO}_{3}$ & 0 & 0 & 0 & 0 & 0 & 0 & 0 & 0 & 0 & 0 & 0.07 & 0.046 & 0 & 0 & 0 & 0 \\
\hline $\mathrm{MgTi}_{2} \mathrm{O}_{4}$ & 0 & 0 & 0 & 0 & 0 & 0 & 0 & 0 & 0 & 0 & 0.155 & 0.053 & 0 & 0 & 0 & 0 \\
\hline $\mathrm{NiTiO}_{3}$ & 0 & 0 & 0 & 0 & 0 & 0 & 0 & 0 & 0 & 0 & 0 & 0 & 0 & 0 & 0 & 0 \\
\hline Galonite & 0 & 0 & 0 & 0 & 0 & 0 & 0 & 0 & 0 & 0 & 0 & 0 & 0 & 0 & 0 & 0 \\
\hline Psb & 0 & 0 & 0 & 0 & 0 & 0 & 0 & 0 & 0 & 0 & 0 & 0 & 0.129 & 0.039 & 0 & 0 \\
\hline Fe-psb & 0 & 0 & 0 & 0 & 0 & 0 & 0 & 0 & 0 & 0 & 0 & 0 & 0 & 0 & 0 & 0 \\
\hline Mg-psb & 0 & 0 & 0 & 0 & 0 & 0 & 0 & 0 & 0 & 0 & 0 & 0 & 0 & 0 & 0 & 0 \\
\hline Ilmenite & 0 & 0 & 0 & 0 & 0 & 0 & 0.085 & 0.034 & 0 & 0 & 0 & 0 & 0 & 0 & 0 & 0 \\
\hline CLP & 0 & 0 & 0.106 & 0.072 & 0 & 0 & 0 & 0 & 0 & 0 & 0 & 0 & 0 & 0 & 0 & 0 \\
\hline P-glass & 0 & 0 & 0.135 & 0.082 & 0 & 0 & 0 & 0 & 0 & 0 & 0 & 0 & 0 & 0 & 0 & 0 \\
\hline Si-glass & 0 & 0 & 0 & 0 & 0 & 0 & 0 & 0 & 0 & 0 & 0 & 0 & 0 & 0 & 0 & 0 \\
\hline $\mathrm{Ca}-\mathrm{Mo}$ & 0 & 0 & 0 & 0 & 0 & 0 & 0 & 0 & 0 & 0 & 0 & 0 & 0 & 0 & 0 & 0 \\
\hline $\mathrm{Ca}-\mathrm{W}$ & 0 & 0 & 0 & 0 & 0 & 0 & 0 & 0 & 0 & 0 & 0 & 0 & 0 & 0 & 0 & 0 \\
\hline $\mathrm{Hf}-\mathrm{Ti}$ & 0 & 0 & 0 & 0 & 0 & 0 & 0 & 0 & 0 & 0 & 0 & 0 & 0 & 0 & 0 & 0 \\
\hline
\end{tabular}


Table 3 (cont.). Phase fractions based on linear regression of bulk and phase compositions

\begin{tabular}{|c|c|c|c|c|c|c|c|c|c|c|c|c|c|c|c|c|}
\hline & $9 / 3$ & \pm & $10 / 1$ & \pm & $11 / 1$ & \pm & $12 / 1$ & \pm & $13 / 1$ & \pm & $15 / 1$ & \pm & $16 / 1$ & \pm & $17 / 1$ & \pm \\
\hline Py & 0.797 & 0.07 & 0 & 0 & 0.651 & 0.096 & 0.886 & 0.069 & 0.84 & 0.079 & 0.791 & 0.063 & 0.556 & 0.078 & 0.85 & 0.076 \\
\hline $\mathrm{Brn}$ & 0 & 0 & 0.376 & 0.055 & 0 & 0 & 0 & 0 & 0 & 0 & 0 & 0 & 0 & 0 & 0 & 0 \\
\hline Hfn & 0 & 0 & 0 & 0 & 0.157 & 0.115 & 0 & 0 & 0.1 & 0.077 & -0.002 & 0.047 & -0.043 & 0.055 & 0.01 & 0.077 \\
\hline $\mathrm{Ru}$ & 0 & 0 & -0.048 & 0.029 & 0 & 0 & 0 & 0 & 0 & 0 & 0 & 0 & 0 & 0 & 0 & 0 \\
\hline $\mathrm{Pv}$ & 0.231 & 0.049 & 0 & 0 & 0 & 0 & 0 & 0 & 0 & 0 & 0 & 0 & 0 & 0 & 0 & 0 \\
\hline CTA & 0 & 0 & 0 & 0 & 0 & 0 & 0 & 0 & 0.056 & 0.033 & 0 & 0 & 0 & 0 & 0 & 0 \\
\hline $\mathrm{MgTiO}_{3}$ & 0 & 0 & 0 & 0 & 0 & 0 & 0 & 0 & 0 & 0 & 0 & 0 & 0 & 0 & 0 & 0 \\
\hline $\mathrm{MgTi}_{2} \mathrm{O}_{4}$ & 0 & 0 & 0 & 0 & 0 & 0 & 0 & 0 & 0 & 0 & 0 & 0 & 0 & 0 & 0 & 0 \\
\hline $\mathrm{NiTiO}_{3}$ & 0 & 0 & 0 & 0 & 0 & 0 & 0 & 0 & 0 & 0 & 0 & 0 & 0 & 0 & 0.155 & 0.033 \\
\hline Galonite & 0 & 0 & 0 & 0 & 0 & 0 & 0 & 0 & 0 & 0 & 0 & 0 & 0 & 0 & 0 & 0 \\
\hline Psb & 0 & 0 & 0 & 0 & 0 & 0 & 0 & 0 & 0 & 0 & 0 & 0 & 0 & 0 & 0 & 0 \\
\hline Fe-psb & 0 & 0 & 0 & 0 & 0.195 & 0.033 & 0 & 0 & 0 & 0 & 0 & 0 & 0 & 0 & 0 & 0 \\
\hline Mg-psb & 0 & 0 & 0 & 0 & 0 & 0 & 0.094 & 0.048 & 0 & 0 & 0 & 0 & 0 & 0 & 0 & 0 \\
\hline Ilmenite & 0 & 0 & 0 & 0 & 0 & 0 & 0 & 0 & 0 & 0 & 0 & 0 & 0 & 0 & 0 & 0 \\
\hline CLP & 0 & 0 & 0 & 0 & 0 & 0 & 0 & 0 & 0 & 0 & 0 & 0 & 0 & 0 & 0 & 0 \\
\hline P-glass & 0 & 0 & 0 & 0 & 0 & 0 & 0 & 0 & 0 & 0 & 0 & 0 & 0 & 0 & 0 & 0 \\
\hline Si-glass & 0 & 0 & 0.696 & 0.068 & 0 & 0 & 0 & 0 & 0 & 0 & 0.199 & 0.052 & 0.476 & 0.068 & 0 & 0 \\
\hline Ca-Mo & 0 & 0 & 0 & 0 & 0 & 0 & 0 & 0 & 0 & 0 & 0 & 0 & 0 & 0 & 0 & 0 \\
\hline $\mathrm{Ca}-\mathrm{W}$ & 0 & 0 & 0 & 0 & 0 & 0 & 0 & 0 & 0 & 0 & 0 & 0 & 0 & 0 & 0 & 0 \\
\hline Hf-Ti & 0 & 0 & 0 & 0 & 0 & 0 & 0 & 0 & 0 & 0 & 0 & 0 & 0 & 0 & 0 & 0 \\
\hline
\end{tabular}


Table 3 (cont.). Phase fractions based on linear regression of bulk and phase compositions

\begin{tabular}{|c|c|c|c|c|c|c|c|c|c|c|c|c|c|c|c|c|}
\hline & $18 / 1$ & \pm & $19 / 1$ & \pm & $20 / 1$ & \pm & $21 / 1$ & \pm & $22 / 1$ & \pm & P229 & & $\mathrm{P} 232$ & & $\mathrm{P} 243$ & \\
\hline Py & 0.777 & 0.044 & 0.611 & 0.086 & 1.075 & 0.029 & 1.002 & 0.069 & 1.003 & 0.073 & 0.576 & 0.069 & 0.781 & 0.094 & 0.667 & 0.152 \\
\hline $\mathrm{Bm}$ & 0 & 0 & 0 & 0 & 0 & 0 & 0 & 0 & 0 & 0 & 0.359 & 0.056 & 0.17 & 0.073 & 0.479 & 0.156 \\
\hline $\mathrm{Hfn}$ & 0.018 & 0.039 & 0.277 & 0.115 & 0 & 0 & 0 & 0 & 0 & 0 & 0 & 0 & 0 & 0 & 0 & 0 \\
\hline $\mathrm{Ru}$ & 0.143 & 0.03 & 0 & 0 & 0 & 0 & 0.043 & 0.04 & 0.034 & 0.041 & 0 & 0 & 0 & 0 & 0 & 0 \\
\hline $\mathrm{Pv}$ & 0 & 0 & 0 & 0 & -0.024 & 0.021 & 0 & 0 & 0 & 0 & 0 & 0 & 0.047 & 0.018 & -0.057 & 0.065 \\
\hline CTA & 0 & 0 & 0 & 0 & 0 & 0 & 0 & 0 & 0 & 0 & 0 & 0 & 0 & 0 & 0 & 0 \\
\hline $\mathrm{MgTiO}_{3}$ & 0 & 0 & 0 & 0 & 0 & 0 & 0 & 0 & 0 & 0 & 0 & 0 & 0 & 0 & 0 & 0 \\
\hline $\mathrm{MgTi}_{2} \mathrm{O}_{4}$ & 0 & 0 & 0 & 0 & 0 & 0 & 0 & 0 & 0 & 0 & 0 & 0 & 0 & 0 & 0 & 0 \\
\hline $\mathrm{NiTiO}_{3}$ & 0 & 0 & 0 & 0 & 0 & 0 & 0 & 0 & 0 & 0 & 0 & 0 & 0 & 0 & 0 & 0 \\
\hline Galonite & 0 & 0 & 0.1 & 0.073 & 0 & 0 & 0 & 0 & 0 & 0 & 0 & 0 & 0 & 0 & 0 & 0 \\
\hline Psb & 0 & 0 & 0 & 0 & 0 & 0 & 0 & 0 & 0 & 0 & 0 & 0 & 0 & 0 & 0 & 0 \\
\hline Fe-psb & 0 & 0 & 0 & 0 & 0 & 0 & 0 & 0 & 0 & 0 & 0 & 0 & 0 & 0 & 0 & 0 \\
\hline Mg-psb & 0 & 0 & 0 & 0 & 0 & 0 & 0 & 0 & 0 & 0 & 0 & 0 & 0 & 0 & 0 & 0 \\
\hline Ilmenite & 0 & 0 & 0 & 0 & 0 & 0 & 0 & 0 & 0 & 0 & 0 & 0 & 0 & 0 & 0 & 0 \\
\hline CLP & 0 & 0 & 0 & 0 & 0 & 0 & 0 & 0 & 0 & 0 & 0 & 0 & 0 & 0 & 0 & 0 \\
\hline P-glass & 0 & 0 & 0 & 0 & 0 & 0 & 0 & 0 & 0 & 0 & 0 & 0 & 0 & 0 & 0 & 0 \\
\hline Si-glass & 0 & 0 & 0 & 0 & 0 & 0 & 0 & 0 & 0 & 0 & 0 & 0 & 0 & 0 & 0 & 0 \\
\hline Ca-Mo & 0 & 0 & 0 & 0 & 0 & 0 & 0 & 0 & 0 & 0 & 0.137 & 0.012 & 0 & 0 & 0 & 0 \\
\hline $\mathrm{Ca}-\mathrm{W}$ & 0 & 0 & 0 & 0 & 0 & 0 & 0 & 0 & 0 & 0 & 0 & 0 & 0.061 & 0.021 & 0 & 0 \\
\hline Hf-Ti & 0 & 0 & 0 & 0 & 0 & 0 & 0 & 0 & 0 & 0 & 0 & 0 & 0 & 0 & 0.02 & 0.049 \\
\hline
\end{tabular}




\subsection{Insoluble Impurities}

\subsubsection{The baseline assemblage}

Two Ce-analog baseline mixtures were synthesized in order to compare the resulting phase assemblage as a function of starting materials (Plate 1). The first, M1, was made from a combination of nitrates, ammoniates and oxides, while the second, M5, was made strictly from oxides and carbonates. Runs were performed in air at $1300^{\circ} \mathrm{C}, 1350^{\circ} \mathrm{C}$ and $1400^{\circ} \mathrm{C}$ and produce the assemblage pyrochlore+rutile \pm brannerite (Table 3). Brannerite was found in all of the runs synthesized from oxides, and in all but the $1350^{\circ} \mathrm{C}$ run from the M1 compositions. Its absence in run "1/3" may simply be the result of small variations in bulk chemistry, kinetics, or difficulties associated in detecting phases with low modal abundance

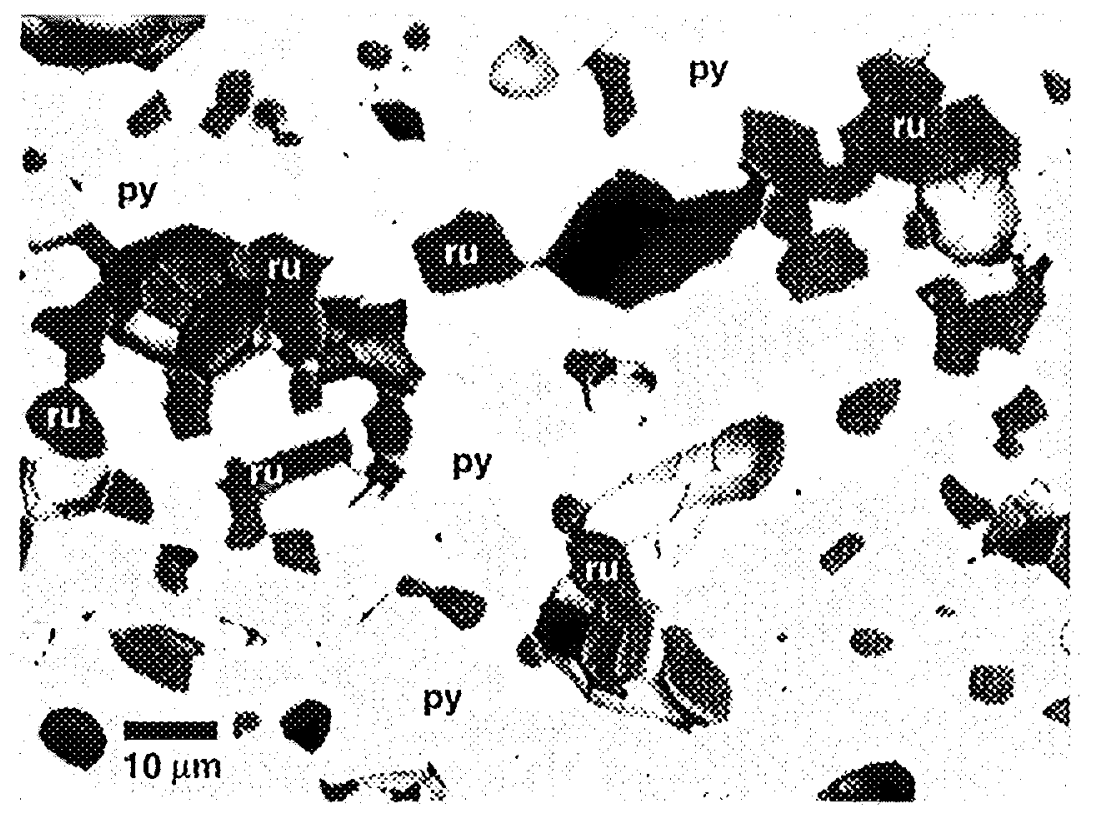

Plate 1a. Backscattered electron image of Ce-analog baseline formulation sintered at $1350^{\circ} \mathrm{C}$ in air (1/3). Phase assemblage includes pyrochlore (py) and rutile (ru). 
The compositions of the individual phases do not show significant variation as a function of either starting material or run temperature (Tables $\mathrm{C} 1$ and $\mathrm{C} 2$ ). The typical pyrochlore composition (see sample 1/3, Table C1) is $\left.\mathrm{Ca}_{1.02} \mathrm{Ce}_{0.25} \mathrm{Gd}_{0.23} \mathrm{Hf}_{0.16} \mathrm{U}_{0.35}\right)\left(\mathrm{Ti}_{1.93} \mathrm{Hf}_{0.06} \mathrm{Al}_{0.02}\right) \mathrm{O}_{6.74}$, in which Ce replaces $\mathrm{Pu}$, is somewhat different from that in the nominal baseline formulation, $\left(\mathrm{Ca}_{0.89} \mathrm{Gd}_{0.22} \mathrm{Hf}_{0.23} \mathrm{U}_{0.44} \mathrm{Pu}_{0.22}\right) \mathrm{Ti}_{2} \mathrm{O}_{7}$. The observed $\mathrm{Ce} / \mathrm{Gd}$ ratio in pyrochlore, 1.02 , is equal, within error, to that in the bulk composition, 1.04, and is consistent with the modal predominance of this phase. The observed analog pyrochlore composition is higher in calcium than that used in the target formulation, however. Mass balance, therefore requires the presence of a phase with lower calcium content, explaining the common occurrence of brannerite. The observed pyrochlore is also slightly lower in titanium and uranium than that of the baseline model.

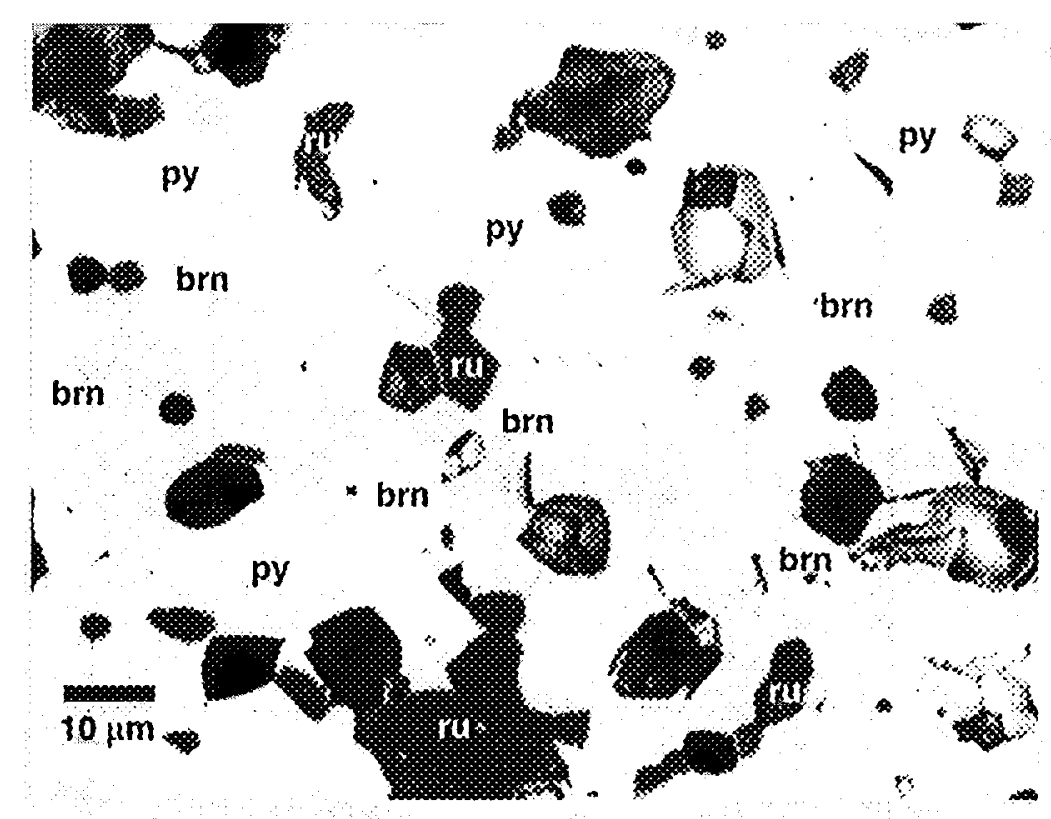

Plate 1b. Backscattered electron image of Ce-analog baseline formulation sintered at $1350^{\circ} \mathrm{C}$ in air (5/3). Phase assemblage includes pyrochlore (py), brannerite (brn) and rutile (ru). Materials synthesized from oxide and carbonates only.

Brannerite displays little run-to-run variation in chemistry, and has an average composition of $\left(\mathrm{Ca}_{0.11} \mathrm{Ce}_{0.22} \mathrm{Gd}_{0.15} \mathrm{Hf}_{0.12} \mathrm{U}_{0.43}\right) \mathrm{Ti}_{1.95} \mathrm{O}_{5.7}$; the Ti-site is essentially full. The average rutile composition, $\left(\mathrm{U}_{0.01} \mathrm{Hf}_{0.09} \mathrm{Ti}_{0.9}\right) \mathrm{O}_{2}$, is somewhat depleted in hafnium relative to the target composition used in the formulation, $\left(\mathrm{Hf}_{0.2} \mathrm{Ti}_{0.8}\right) \mathrm{O}_{2}$. The disparity can be resolved 
by minor variation in the modal abundance and also by the presence of brannerite in most runs.

Using the average phase compositions given above, and the "as-made" composition of M1, the modal phase proportions determined by linear regression are $75 \pm 8 \mathrm{wt} \%$ pyrochlore, $24 \pm 7 \mathrm{wt} \%$ brannerite and $2 \pm 1 \mathrm{wt} \%$ rutile. These proportions are substantially different from the target concentrations, reflecting the disparity between target and observed phase compositions.

Both pyrochlore and brannerite are oxygen deficient for stoichiometries based upon $\mathrm{Ce}^{+3}$ and $\mathrm{U}^{+4}$. For instance, if uranium and cerium are assumed to be present as +4 and +3 cations, respectively, then the average pyrochlore has only 6.7 oxygens per 4 cations, rather than the ideal 7 oxygen per formula unit (pfu). These disparities can be resolved if some combination of $\mathrm{U}$ and $\mathrm{Ce}$ are present in a higher oxidation state. Unfortunately, a unique valence distribution cannot be determined from chemical analysis alone.

Fortner et al. (1999) have determined the valence of $\mathrm{Ce}$ and $\mathrm{U}$ in a ceramic formulation similar to that presented here by XANES and EXAFS spectroscopy. They find that cerium exists in a mixed oxidation state $\left(\mathrm{Ce}^{+4} / \Sigma \mathrm{Ce} \sim 0.33\right)$ and that uranium is present largely as the pentavalent species (personal communication, 1999). It is likely, however, that addition of other components will perturb the valence states of these cations even at constant external conditions. By assuming a fixed $\mathrm{Ce}^{+4} / \Sigma \mathrm{Ce}$ ratio, we calculate the "average valence" of uranium based on the ideal $4 / 7$ and $3 / 6$ stoichiometries of pyrochlore/hafnolite and brannerite, respectively. As various combinations of valence states can satisfy the ideal stoichiometry, the result obtained is not unique, nor does it resolve the distribution of uranium among $\mathrm{U}^{+4}, \mathrm{U}^{+5}$ and $\mathrm{U}^{+6}$.

If we assume that $\mathrm{Ce}^{+4} / \Sigma \mathrm{Ce} \sim 0.33$, we obtain average valence for uranium (expressed as $\mathrm{x}$ in $\mathrm{UO}_{\mathrm{x}}$ ) of $2.62 \pm 0.08(2 \delta)$, which is equivalent to $\mathrm{U}^{+5.24}$, for our experiments on the 
impurity-free baseline composition (Tables 4 and 5). The agreement between this calculation and the spectroscopic determinations of Fortner et al. (1999), suggests, that while our calculation cannot provide a unique valence determination, it does, however, allow simple comparison between different materials, and can act as monitor of the effects of minor element addition.

\subsubsection{The baseline assemblage with $10 \mathrm{wt} \% \mathrm{Al}_{2} \mathrm{O}_{3}$}

The addition of $\mathrm{Al}_{2} \mathrm{O}_{3}$ to the baseline formulation stabilizes hafnolite and an Al-rich accessory mineral (Table 2). At $1300^{\circ} \mathrm{C}$ the Al-rich phase is corundum in equilibrium with rutile. At higher temperatures, these phases react to form $\mathrm{Al}$-psuedobrookite, $\mathrm{Al}_{2} \mathrm{TiO}_{5}$. The individual phases are $5-10 \mu \mathrm{m}$ in diameter with brannerite and Al-psuedobrookite being

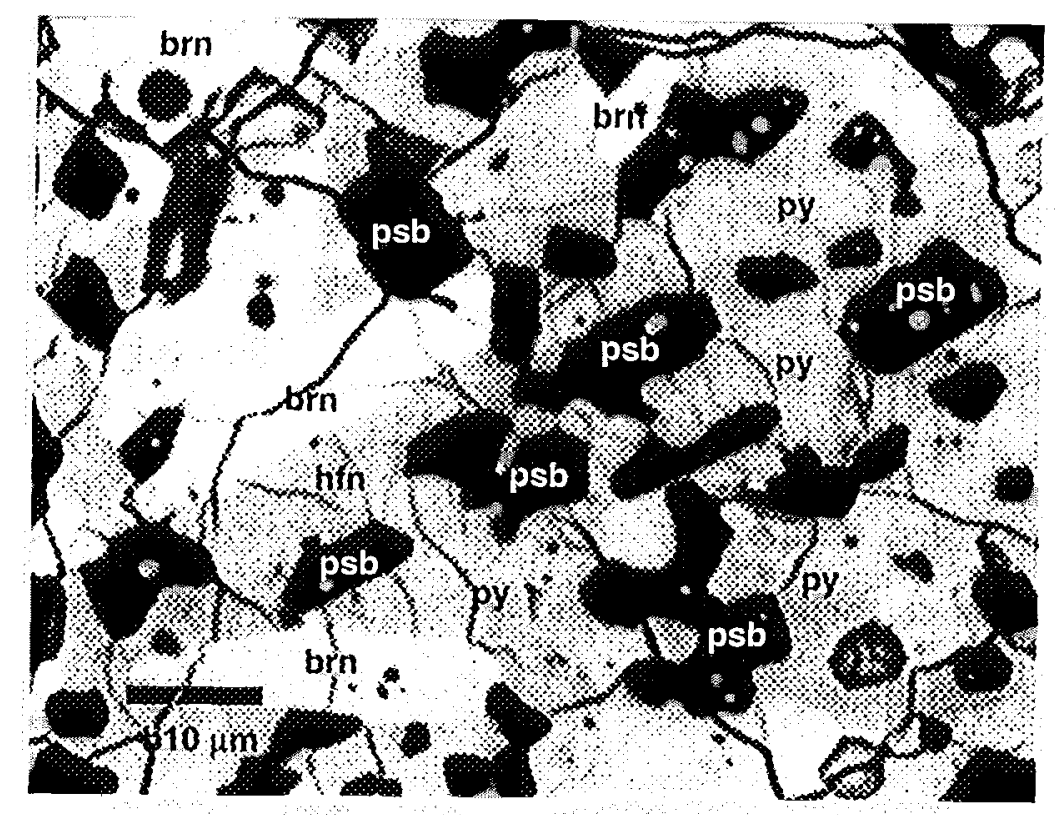

Plate 2. Baseline formulation with $10 \mathrm{wt} \% \mathrm{Al}_{2} \mathrm{O}_{3}$ added. Sintered at $1350^{\circ} \mathrm{C}$ in air (7/3). Phase assemblage includes pyrochlore (py), brannerite (brn), hafnolite (hfn) and rutile (ru).

somewhat elongate (Plate 2). The phases fractions for the $1350^{\circ} \mathrm{C}$ run are given in Table 3 , and indicate that pyrochlore remains the most abundant phase $(\sim 52 \mathrm{wt} \%)$. Both corundum and $\mathrm{Al}$-psuedobrookite are essentially free of constituents other than $\mathrm{Al}_{2} \mathrm{O}_{3}$ and $\mathrm{TiO}_{2}$ (Table C3). Hafnolite contains $\sim 4 \mathrm{wt} \% \mathrm{Al}_{2} \mathrm{O}_{3}$ and has the structural formula $\left(\mathrm{Ca}_{0.78} \mathrm{Gd}_{0.18}\right)(\mathrm{Al}-$ 
$\left.{ }_{0.09} \mathrm{Ce}_{0.10} \mathrm{Hf}_{0.68} \mathrm{U}_{0.15}\right)\left(\mathrm{Ti}_{1.75} \mathrm{Al}_{0.25}\right) \mathrm{O}_{6.92}$ at $1350^{\circ} \mathrm{C}$. The close approach to 7 oxygens per 4 cations is consistent with uranium and cerium being in the +4 and +3 oxidation states, respectively.

The compositions of pyrochlore and brannerite (Table 6) are virtually identical to those in the baseline formulation, and contain insignificant amounts of $\mathrm{Al}_{2} \mathrm{O}_{3}$. Pyrochlore contains only $\sim 0.4 \mathrm{wt} \% \mathrm{Al}_{2} \mathrm{O}_{3}$ and brannerite $\sim 1.4 \mathrm{wt} \%$. The structural formula for pyrochlore at $1350^{\circ} \mathrm{C}$ is $\left(\mathrm{Ca}_{1.05} \mathrm{Ce}_{0.26} \mathrm{Gd}_{0.21} \mathrm{Hf}_{0.09} \mathrm{U}_{0.38}\right)\left(\mathrm{Ti}_{1.91} \mathrm{Hf}_{0.06} \mathrm{Al}_{0.03}\right) \mathrm{O}_{6.7}$ and that of brannerite is $\mathrm{Ca}_{0.08} \mathrm{Ce}_{0.24} \mathrm{Gd}_{0.13} \mathrm{Hf}_{0.09} \mathrm{U}_{0.46} \mathrm{Ti}_{1.90} \mathrm{Al}_{0.11} \mathrm{O}_{5.68}$, and as is the case with the impurityfree baseline sample they are oxygen deficient which is mostly likely indicative of uranium in an oxidation state greater than +4 . If $\mathrm{Ce}^{+4} / \Sigma \mathrm{Ce}=0.33$, the average uranium valence, $\mathrm{UO}_{\mathrm{x}}$, is close to $x=2.7$ and is within error of the value obtained for the impurity-free baseline formulation, consistent with the overall similarity in phase composition and the low concentrations of $\mathrm{Al}_{2} \mathrm{O}_{3}$ in brannerite and pyrochlore.

The low concentrations of $\mathrm{Al}_{2} \mathrm{O}_{3}$ in pyrochlore and brannerite indicate that even small amounts of $\mathrm{Al}_{2} \mathrm{O}_{3}$ in the waste stream will result in either the formation or hafnolite on an Al-rich accessory phase. For instance, if the desired phase assemblage was formulated to produce a pyrochlore-rutile assemblage, molar ratio above 0.08 moles $\mathrm{Al}_{2} \mathrm{O}_{3} /$ mole of $\mathrm{PuO}_{2}$ would result in the stabilization of Al-psuedobrookite at $1350^{\circ} \mathrm{C}$. However, the Al-rich accessory phases do not alter the ratio of $\mathrm{Pu}$ to neutron absorbers in pyrochlore or brannerite, and they contain no plutonium. As such, its presence will have negligible effect on the wasteform performance.

\subsubsection{The baseline assemblage with $10 \mathrm{wt} \% \mathrm{Fe}_{2} \mathrm{O}_{3}$}

For materials synthesized at $1300^{\circ} \mathrm{C}$ the addition of $10 \mathrm{wt} \% \mathrm{Fe}_{2} \mathrm{O}_{3}$ yields results similar to those observed for the $\mathrm{Al}_{2} \mathrm{O}_{3}$. Iron stabilizes hafnolite, and a Fe-rich accessory phase, ilmenite (Table 2). With the exception of a small amount of $\mathrm{HfO}_{2}$, ilmenite contains only iron and titanium. However, pyrochlore and brannerite do contain significant iron and 
are somewhat different in composition from those in the baseline composition (Table C4). Pyrochlore has the structural formula $\left(\mathrm{Ca}_{1.09} \mathrm{Ce}_{0.25} \mathrm{Gd}_{0.14} \mathrm{Fe}_{0.07} \mathrm{U}_{0.45}\right)\left(\mathrm{Ti}_{1.85} \mathrm{Hf}_{0.07} \mathrm{Al}_{0.04} \mathrm{Fe}_{0.07}\right) \mathrm{O}_{6.43}$ and contains $\sim 2.4$ wt\% FeO. Brannerite, $\left(\mathrm{Ca}_{0.11} \mathrm{Ce}_{0.24} \mathrm{Gd}_{0.10} \mathrm{Hf}_{0.04} \mathrm{U}_{0.49}\right)\left(\mathrm{Ti}_{1.84} \mathrm{Al}_{0.01} \mathrm{Fe}_{0.17}\right) \mathrm{O}_{5.39}$ and contains $-3 \mathrm{wt} \% \mathrm{FeO}$. Of the primary phases hafnolite contains the highest concentration of iron at $\sim 11 \mathrm{wt} \%$. The concentration of iron in hafnolite, $\left(\mathrm{Ca}_{0.62} \mathrm{Ce}_{0.17} \mathrm{Gd}_{0.17} \mathrm{U}_{0.05}\right)\left(\mathrm{Fe}_{0.56} \mathrm{Hf}_{0.32} \mathrm{U}_{0.12}\right)\left(\mathrm{Ti}_{1.90} \mathrm{Al}_{0.03} \mathrm{Fe}_{0.07}\right) \mathrm{O}_{5.94}$, alters the nominal phase proportions such that the weight fractions of both pyrochlore and hafnolite are $\sim 40 \mathrm{wt} \%$ of the sample (Table 3). The presence of iron also appears to alter the partitioning of neutron absorbing elements relative to that in the impurity-free $\mathrm{Ce}$-analog, as the $\mathrm{Ce} / \mathrm{Gd}$ ratio in the pyrochlore in this run is 1.7 while that in the baseline composition is $\sim 1$.

When calculated as $\mathrm{Ce}^{+3}, \mathrm{U}^{+4}$ and $\mathrm{Fe}^{+2}$, pyrochlore, hafnolite and brannerite are quite oxygen deficient, 6.5 oxygens/4 cations and 5.9 oxygens per 4 cations, respectively, and the deficiency correlates with iron concentration. However, if $\mathrm{Fe}$ is cast as $\mathrm{Fe}^{+3}$ values of $\mathrm{UO}_{\mathrm{x}}$ close to those of the baseline formulation and $\mathrm{Al}_{2} \mathrm{O}_{3}$-doped run products are obtained, suggesting that the iron is present primarily as $\mathrm{Fe}^{+3}$ in these materials. This is not the case for the ilmentie-hematite phase $\left(\mathrm{FeTiO}_{3}-\mathrm{Fe}_{2} \mathrm{O}_{3}\right)$ in which the $\mathrm{Fe}^{+3} / \Sigma \mathrm{Fe}=0.41$. the substitution of $\mathrm{Fe}^{+3}$ for quadravalent cations may enhance the solubility of lanthanides in pyrochlore via $\mathrm{Ca}^{+2}+\mathrm{U}^{+4}=2 \mathrm{Gd}^{+3}$.

Stewart et al. (1999) added Fe along with a suite of other divalent cations ( $\mathrm{Mg}, \mathrm{Co}, \mathrm{Ni}$, $\mathrm{Cu}, \mathrm{Zn}, \sim 16 \mathrm{wt} \%$ total) to the baseline formulation. Instead of ilmenite, they observed an ulvöspinel-rich spinel solid solution $\left(\mathrm{M}_{2} \mathrm{TiO}_{4}\right.$, where $\mathrm{M}$ is a divalent cation). The difference between the two sets of experiments can be explained by the ability of $\mathrm{Fe}$ to exist as $\mathrm{Fe}^{+2}$ and/or $\mathrm{Fe}^{+3}$ rather than to be wholly divalent. As such, $\mathrm{Fe}^{+3}$ stabilizes the ilmenite solid solution by increasing the activity of $\mathrm{Fe}_{2} \mathrm{O}_{3}$, while divalent cations favor ulvöspinel. Ilmenite is also stabilized by the higher $\mathrm{Ti} / \mathrm{Fe}$ ratio of our materials. 
A more serious concern with respect to the addition of $\mathrm{Fe}$ is that samples synthesized at $1350^{\circ} \mathrm{C}$ and $1400^{\circ} \mathrm{C}$ both melted and could not be recovered for analysis. The presence of a eutectic in the pyrochlore-brannerite-hafnolite-ilmenite field at these temperatures limits the compositional range for successful synthesis. If the composition of pyrochlore is taken as a limit on the $\mathrm{Fe}$ content, then the limiting ratio of $\mathrm{Fe}$ could be as low as 0.56 moles for $\mathrm{FeO} /$ mole of $\mathrm{PuO}_{2}$. Perhaps a more realistic estimate can be obtained by eliminating ilmenite from the assemblage and combining pyrochlore, hafnolite and brannerite in a 0.4:0.4:0.2 weight ratio yielding an composition with a ratio of moles $\mathrm{FeO}$ per mole of $\mathrm{PuO}_{2}$ equal to 1.6. An absolute upper limit is given by the composition of hafnolite in which the moles for $\mathrm{FeO} /$ mole of $\mathrm{PuO}_{2}$ is 3.74 .

\subsubsection{The baseline assemblage with $10 \mathrm{wt} \% \mathrm{MgO}$}

The assemblages resulting from the addition of $\mathrm{MgO}$ vary with synthesis temperature (Table 2). At $1300^{\circ} \mathrm{C}$ pyrochlore, hafnolite, perovskite and $\mathrm{MgTiO}_{3}$ coexist. At $1350^{\circ} \mathrm{C}$ hafnolite disappears and is replaced by $\mathrm{Mg}_{2} \mathrm{TiO}_{4}$ (Plate 3). Finally at $1400^{\circ} \mathrm{C}$ perovskite is no longer part of the assemblage. However, regression analysis indicates that only pyrochlore, which is always greater than $80 \mathrm{wt} \%$ of the sample (Table 3) and the $\mathrm{Mg}$ titanates are present in non-negligible amounts. In addition to $\mathrm{Mg}$ and $\mathrm{Ti}$, the Mg-titanates contain only $\mathrm{HfO}_{2}$ in detectable amounts.

The average pyrochlore formula from the $1350^{\circ} \mathrm{C}$ run is $\left(\mathrm{Ca}_{1.01} \mathrm{Ce}_{0.26} \mathrm{Gd}_{0.24} \mathrm{U}_{0.46}\right)\left(\mathrm{Ti}_{1.51} \mathrm{Hf}_{0.30} \mathrm{Mg}_{0.22}\right) \mathrm{O}_{6.53}$ (Table C5). The Ca content is similar to that in previous experiments, and since pyrochlore is the only modally significant lanthanidebearing phase, the $\mathrm{Ce} / \mathrm{Gd}$ ratio approximates that of the starting material. The $\mathrm{Hf}$ concentration of pyrochlore is somewhat higher than that of materials containing either brannerite or hafnolite.

The Ti content of both pyrochlore and hafnolite are significantly lower than that in the impurity-free or $\mathrm{Al}$-doped runs (Table $\mathrm{C} 1, \mathrm{C} 2, \mathrm{C} 3$ and $\mathrm{C}$ ). If, due to its small cationic 


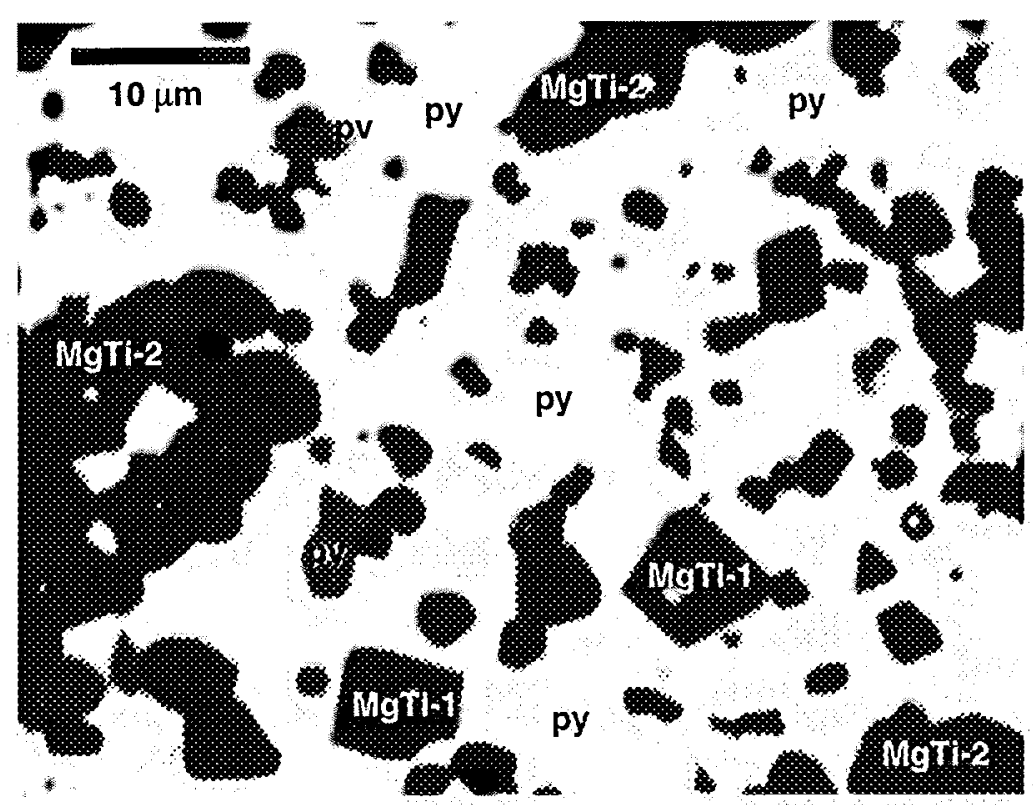

Plate 3. Backscattered electon image of baseline formulation with $10 \mathrm{wt} \% \mathrm{MgO}$ added. Sintered at $1350^{\circ} \mathrm{C}$ in air (6/3). Phase assemblage includes pyrochlore (py), perovskite (pv) and two magnesium titanates, $\mathrm{MgTiO}_{3}(\mathrm{MgTi}-1)$ and $\mathrm{Mg}_{2} \mathrm{TiO}_{4}(\mathrm{MgTi}-2)$.

radius, $\mathrm{Mg}^{+2}$ substitutes for Ti on the Ti-site, then the Ti-site will be charge deficient. One way to maintain charge compensation is to oxidize either $U$ and/or Ce on the A-site. This appears to be the case. For $\mathrm{Ce}^{+4} / \Sigma \mathrm{Ce}=0.33$, the average uranium valence of pyrochlore is $\sim \mathrm{UO}_{2.9}$ as opposed to $\mathrm{UO}_{2.6}$ in the impurity-free baseline formulation run products. A similar calculation for the hafnolite yields $\mathrm{UO}_{2.7}$ at $1300^{\circ} \mathrm{C}$ (Table C5). Another product of the low Ti content is that the A-site is now free of Hf that resides only on the Ti-site. This could effect the partitioning of hafnium and explain the elevated hafnium concentration levels in the pyrochlores produced here. The addition of $\mathrm{MgO}$ may also effect the partitioning of uranium by coupled substitutions such as,

$$
\mathrm{Mg}^{+2}+\mathrm{U}^{+6}=2 \mathrm{Ti}^{+4}
$$

Indeed, the hafnolite in the $1300^{\circ} \mathrm{C}$ run contains $22.7 \mathrm{wt} \% \mathrm{UO}_{2}$, about 3 times more than in the hafnolites from the Al-doped run products. 
Stewart et al. (1999) added Mg along with a suite of other divalent cations (Mg, Co, $\mathrm{Ni}, \mathrm{Cu}, \mathrm{Zn}, \sim 16 \mathrm{wt} \%$ total) to a Ce-analog formulation and observed an ulvöspinel spinel solid solution, $\mathrm{M}_{2} \mathrm{TiO}_{4}$, where $\mathrm{M}$ is a divalent cation. The $\mathrm{Mg}_{2} \mathrm{TiO}_{4}$ observed here is equivalent to that phase. As the Mg-titanates contain no significant nuclides and the pyrochlore composition is not substantially altered by the presence of $\mathrm{Mg}$, it appears that $\mathrm{MgO}$ may be accommodated in unlimited concentrations. The major effects are the stabilization of hafnolite and the Mg-titanates and to a lesser extent perovskite. Incorporation of $\mathrm{MgO}$ in these phases may also effect the valence states of $\mathrm{U}, \mathrm{Ce}$ and, by extension, $\mathrm{Pu}$.

\subsubsection{The baseline assemblage with $10 \mathrm{wt} \% \mathrm{NiO}$}

The addition of $\mathrm{NiO}$ results in a phase assemblage that is largely pyrochlore and $\mathrm{NiTiO}_{3}$ with minor hafnolite at $1300^{\circ} \mathrm{C}$ and $1350^{\circ} \mathrm{C}$ (Table 2, 3 and $\mathrm{C} 6$, Plate 4). The $\mathrm{NiTiO}_{3}$ is the major repository of $\mathrm{Ni}$ and also contains $\sim 4 \mathrm{wt} \% \mathrm{HfO}_{2}$, but no other neutron

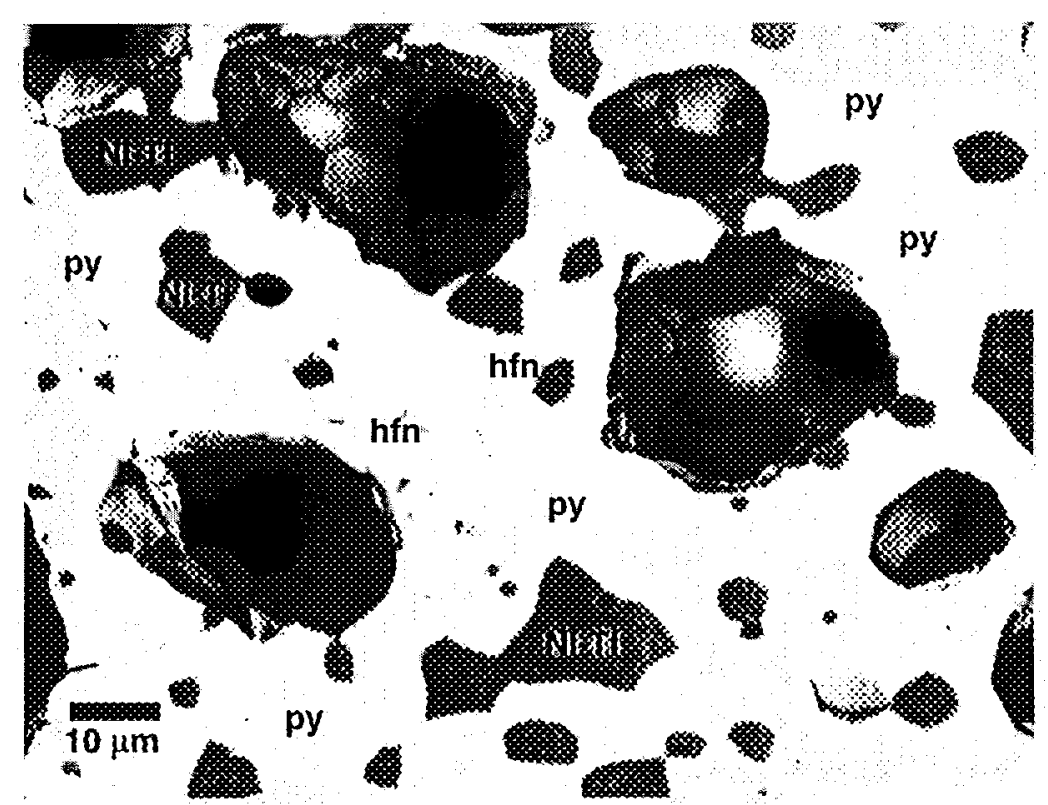

Plate 4. Baseline formulation with $10 \mathrm{wt} \% \mathrm{NiO}$ added. Sintered at $1350^{\circ} \mathrm{C}$ in air (17/1). Phase assemblage includes pyrochlore (py), hafnolite (hfn), and Ni-titanate (Ni-Ti). 
absorbers or cerium. Hafnolite also contains $\mathrm{NiO}(\sim 6 \mathrm{wt} \%)$, but is modally insignificant (Table 3). The pyrochlore formula $\left(1350^{\circ} \mathrm{C}\right)$ resembles that in previous runs and is given by the formula, $\left(\mathrm{Ca}_{1.00} \mathrm{Ni}_{0.13} \mathrm{Ce}_{0.24} \mathrm{Gd}_{0.23} \mathrm{Hf}_{0.01} \mathrm{U}_{0.39}\right)\left(\mathrm{Ti}_{1.79} \mathrm{Hf}_{0.21}\right) \mathrm{O}_{6.63}$. As there are no other lanthanide-bearing phases present, the $\mathrm{Gd} / \mathrm{Ce}$ ratio is that of the starting material. Nickel addition may also effect valence states as it increases the divalent cations content of the Asite in pyrochlore and the $\mathrm{B}$-site in hafnolite. The $\mathrm{UO}_{\mathrm{x}}$ values at $1350^{\circ} \mathrm{C}$, assuming $\mathrm{Ce}^{+4} / \Sigma \mathrm{Ce}=0.33$ are $\mathrm{x}=2.85$ and $\mathrm{x}=2.7$, respectively, for pyrochlore and hafnolite. Oxidation of uranium or cerium maintains charge balance. As such, the only real effect of adding $\mathrm{Ni}$ to the sample is to produce radionuclide and neutron absorber-free $\mathrm{NiTiO}_{3}$, and therefore does not limit the composition of the wasteform.

\subsubsection{The baseline assemblage with $10 \mathrm{wt} \% \mathrm{CuO}$}

The results from experiments at $1300^{\circ} \mathrm{C}$ and $1350^{\circ} \mathrm{C}$ in which $\mathrm{CuO}$ was added are equivocal, as it appears to have almost completely volatilized, producing the baseline assemblage pyrochlore plus rutile (Table 2, 3 and C7). Minor amounts of $\mathrm{CuO}$ are

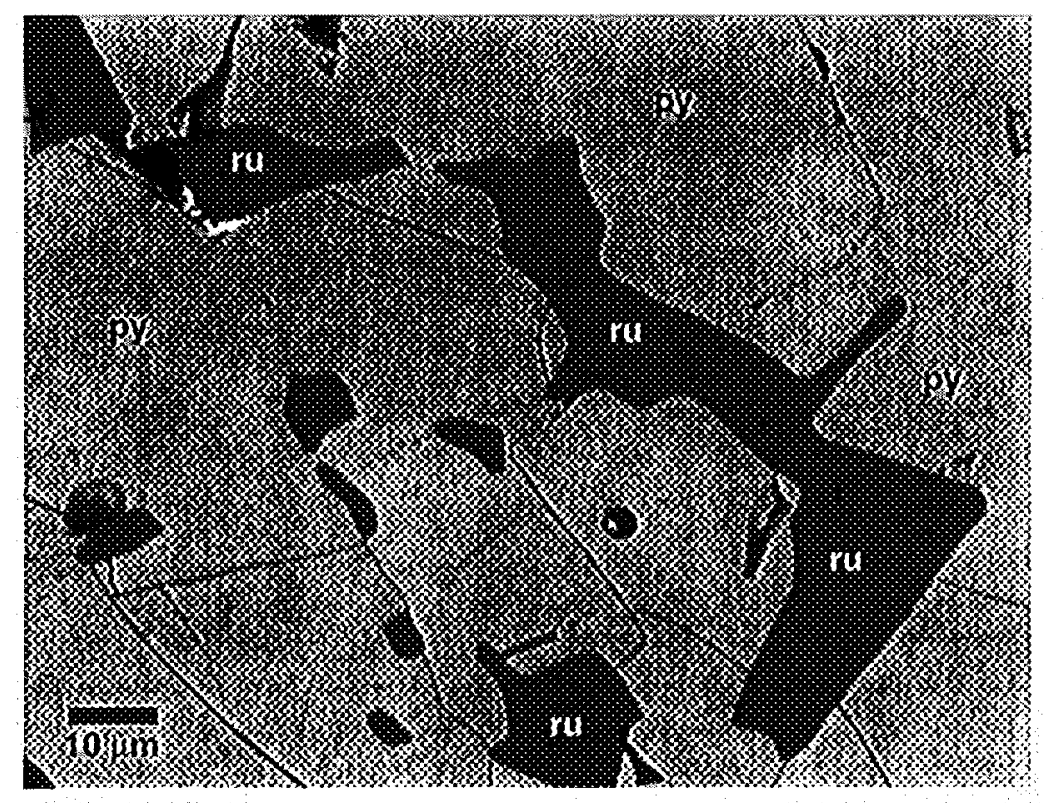

Plate 5. Baseline formulation with $10 \mathrm{wt} \% \mathrm{CuO}$ added. Sintered at $1350^{\circ} \mathrm{C}$ in air (21/1). Phase assemblage includes pyrochlore (py) and rutile (ru). 
detectable in pyrochlore at the 1-2 wt\% level, but are close to detection limits in rutile (Table $\mathrm{C} 7$ ). One noticeable feature of the $\mathrm{CuO}$-bearing runs is the relatively large grain size (Plate 5); pyrochlore grains are in excess of $30 \mu \mathrm{m}$ in diameter relative to $10 \mu \mathrm{m}$ or less in most other runs. This suggests that $\mathrm{CuO}$ may have acted as a flux during sintering of these materials. In fact, a run at $1400^{\circ} \mathrm{C}$ melted. Given the intended processing range of 1300 $1350^{\circ} \mathrm{C}$ it is likely that $\mathrm{CuO}$ will not limit the composition of the wasteform as it will be lost to volatilization. However, caution should be exercised for production sized material where rapid sintering of the outer portions of a puck could inhibit volatile loss from the interior, enhancing the potential for melting. Otherwise, the pyrochlore and rutile compositions and the values of $\mathrm{UO}_{\mathrm{x}}$ required for stoichiometry, $\mathrm{x}=2.68$, are virtually indistinguishable from the baseline formulation run products (Tables $\mathrm{C} 1$ and $\mathrm{C} 7$ )

\subsubsection{The baseline assemblage with $10 \mathrm{wt} \% \mathrm{ZnO}$}

The results of $\mathrm{ZnO}$-bearing runs are quite similar to those from the Cu-bearing experiments (Table 2, 3 and C8). The $\mathrm{Zn}$-bearing runs have grain sizes near $30 \mu \mathrm{m}$, similar to those in the Cu-bearing runs (Plate 6), suggesting that $\mathrm{ZnO}$ may also act as a flux during sintering. At $1350^{\circ} \mathrm{C}$ the assemblage is pyrochlore plus rutile. The concentration of $\mathrm{ZnO}$ in both phases is close to the detection limit. However, at $1300^{\circ} \mathrm{C}$ the assemblage is pyrochlore plus hafnolite. Pyrochlore contains $\sim 2 \mathrm{wt} \% \mathrm{ZnO}$ and hafnolite greater than $7 \mathrm{wt} \%$. Clearly, $\mathrm{Zn}$ stabilizes hafnolite at the expense of rutile. It is also clear that the volatilization of $\mathrm{Zn}$ increases between $1300^{\circ} \mathrm{C}$ and $1350^{\circ} \mathrm{C}$.

Using the normal structural assignments, zinc enters the A-site in pyrochlore and the B-site in hafnolite. Like $\mathrm{Ni}$ and $\mathrm{Mg}$ addition, the zinc increases the number of divalent cations on these sites requiring charge excess on adjacent sites, or in a system of fixed composition, increases in cation valence. The later is the case here, as the average uranium

valence for the $1300^{\circ} \mathrm{C} \mathrm{Zn-bearing} \mathrm{runs,} \mathrm{UO}_{2.87}$ and $\mathrm{UO}_{2.85}$ in pyrochlore and hafnolite, respectively, are higher than those of the $1350^{\circ} \mathrm{C}$ runs where $\mathrm{Zn}$ has been volatilized. 


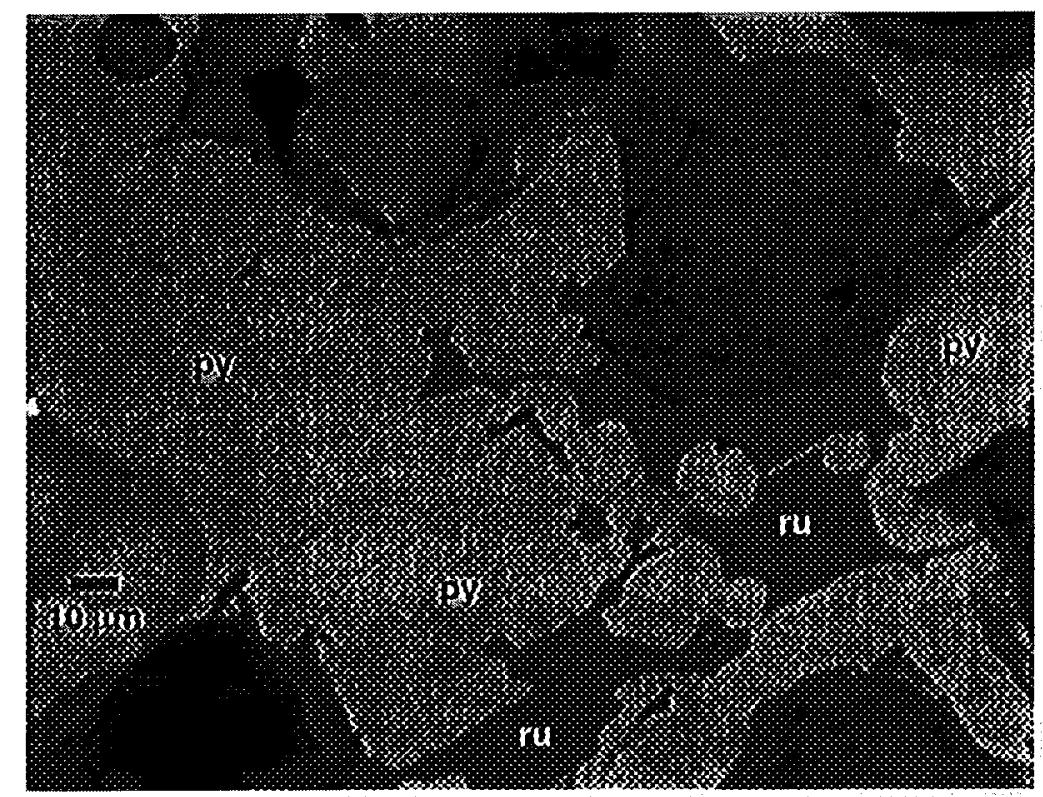

Plate 6. Backscattered electron image of baseline formulation with $10 \mathrm{wt} \% \mathrm{ZnO}$ added. Sintered at $1350^{\circ} \mathrm{C}$ in air (2/3). Phase assemblage includes pyrochlore (py) and rutile (ru).

The $1350^{\circ} \mathrm{C}$ run does not contain a Zn-rich accessory phase, and as such pyrochlore and hafnolite are not buffered with respect to $\mathrm{Zn}$-concentration. This is also the case in the experiments of Stewart et al. (1999) where $\mathrm{Zn}$ was added with a suite of other divalent cations $(\mathrm{Mg}, \mathrm{Co}, \mathrm{Ni}, \mathrm{Cu}$ and $\mathrm{Zn}, \sim 16 \mathrm{wt} \%$ total) which resulted in a pyrochlore, hafnolite, perovskite, ulvöspinel assemblage. Ulvöspinel was the high $\mathrm{Zn}$-phase and the concentration of $\mathrm{Zn}$ in hafnolite was $0.11 \mathrm{Zn}$ per 4 cations as opposed to $0.39 \mathrm{Zn}$ per 4 cations. Hence, it appears that zinc addition has little effect on the phase assemblage, other than to stabilize hafnolite when added alone, or hafnolite and spinel when added with an excess of other divalent cations.

\subsubsection{The baseline assemblage with $10 \mathrm{wt} \% \mathrm{Cr}_{2} \mathrm{O}_{3}$}

The addition of $\mathrm{Cr}_{2} \mathrm{O}_{3}$ stabilizes hafnolite and is also strongly incorporated in rutile (Table 2, 3 and C9, Plate 7). Also present is a poorly characterized sub-mircon size Cr-rich phase; due to the inability to obtain quantitative analyses of this phase, it was not included 
in the regression in Table 3, it is however a minor constituent based upon SEM characterization (Plate 7). Regression analysis indicates that hafnolite is present only at the wt\% level. This is reflected in the pyrochlore composition in which the Ce/Gd ratio is that of the starting material as it is the only lanthanide-bearing phase in the assemblage.

Along with chromium, the rutiles in these experiments also contain significant uranium. For instance, the structural formula for the rutile from the $1350^{\circ} \mathrm{C}$ run is $\mathrm{U}_{0.04} \mathrm{Cr}_{0.11} \mathrm{Hf}_{.07} \mathrm{Ti}_{0.77} \mathrm{O}_{1.94}$. Uranium incorporation can be accomplished by substitutions such as,

$$
\begin{gathered}
\mathrm{U}^{+5}+\mathrm{Cr}^{+3} \Leftrightarrow 2 \mathrm{Ti}^{+4} \\
\mathrm{U}^{+6}+2 \mathrm{Cr}^{+3} \Leftrightarrow 3 \mathrm{Ti}^{+4}
\end{gathered}
$$

The change in rutile chemistry is also reflected in that of pyrochlore composition which has $\sim 1.75 \mathrm{Ti}$ per 4 cations here as opposed to $\sim 1.9 \mathrm{Ti}$ per 4 cations in rutile-saturated impurity-free run products. The incorporation of additional species in rutile decreases the

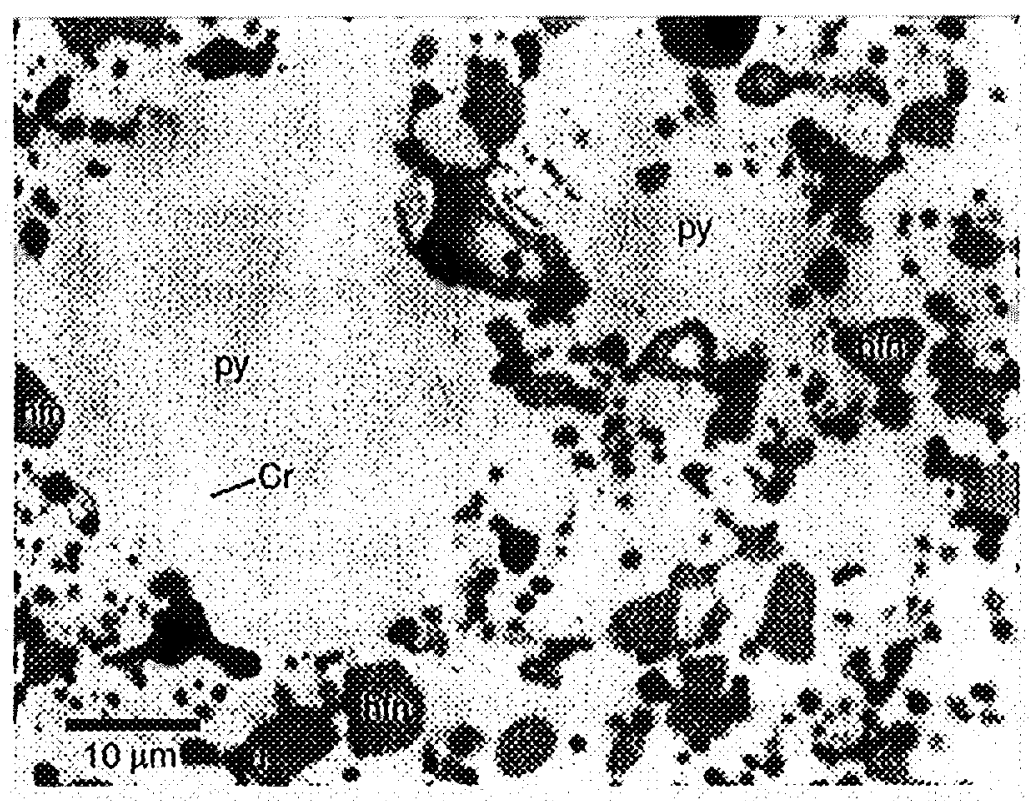

Plate 7. Backscattered electron image of baseline formulation with $10 \mathrm{wt} \% \mathrm{Cr}_{2} \mathrm{O}_{3}$ added. Sintered at $1350^{\circ} \mathrm{C}$ in air (18/1). Phase assemblage includes pyrochlore (py) and hafnolite (hfn), rutile (ru) and $\mathrm{CrxOy}(\mathrm{Cr})$. 
activity of $\mathrm{TiO}_{2}$ in the rutile solid solution and, hence, the entire assemblage, resulting in lower $\mathrm{TiO}_{2}$ contents in the coexisting phases. The reduction of $\mathrm{Ti}$ on the Ti-site also results in a charge deficit (Table C9) which can be compensated by oxidation of uranium and cerium. This is reflected in uranium valences of $\sim \mathrm{UO}_{2.9}$ in pyrochlores from $\mathrm{Cr}$-doped runs relative to $\mathrm{UO}_{2.62}$ in the impurity-free baseline run products.

Stewart et al. (1999) added $\mathrm{Cr}_{2} \mathrm{O}_{3}$ along with $\mathrm{Al}, \mathrm{Mn}, \mathrm{Fe}$, and $\mathrm{Ga}$ to a Pu-bearing baseline formulation and obtained a pyrochlore-hafnolite-magnetoplumbite-loveringite assemblage in air at $1350^{\circ} \mathrm{C}$. Chromium partitioned into hafnolite relative to pyrochlore, but was most strongly enriched in magnetoplumbite and loveringite. Formation of these phases requires additional components be present (iron and gallium in particular). The absence of such elements here explains the presence of $\mathrm{Cr}$-oxide. Cr-oxide buffers the $\mathrm{Cr}_{2} \mathrm{O}_{3}$ activity at values greater than those imposed by magnetoplumbite and loveringite. This is refelected in higher chromium contents in the hafnolites from our experiments, 0.34 Cr per 4 cations versus $0.14 \mathrm{Cr}$ per 4 cations in the run products of Stewart et al. (1999). So, while the addition of $\mathrm{Cr}_{2} \mathrm{O}_{3}$ alone does not significantly alter the composition of pyrochlore or result in the formation of radionuclide-bearing accessory phases, the presence of other trivalent cations can stabilize more complex Cr-bearing phases. Fortunately, neither the magnetoplumbite nor loveringite produced by Stewart et al. (1999) for such compositions contain significant plutonium or uranium.

\subsubsection{The baseline assemblage with $10 \mathrm{wt} \% \mathrm{FeAl}_{2} \mathrm{O}_{4}$}

Ryerson (1984) has described Synroc formulations for US Defense waste immobilization in which zirconolite and perovskite coexist with mixed transition metal aluminate spinels. To evaluate the potential effects of spinel saturation on the current formulation aluminate components were added to the baseline composition.

At $1300^{\circ} \mathrm{C}$ and $1350^{\circ} \mathrm{C}$ the addition of $10 \mathrm{wt} \% \mathrm{FeAl}_{2} \mathrm{O}_{4}$ yields the assemblage pyrochlore, hafnolite and Fe-psuedobrookite (Table 2, 3 and C10). Pyrochlore contains 1- 
$1.5 \mathrm{wt} \% \mathrm{FeO}$ with trace $\mathrm{Al}_{2} \mathrm{O}_{3}$. The average structural formula is $\left(\mathrm{Ca}_{1.02} \mathrm{Fe}_{0.05} \mathrm{Ce}_{0.25} \mathrm{Gd}_{0.24} \mathrm{Hf}_{0.06} \mathrm{U}_{0.38}\right)\left(\mathrm{Ti}_{1.85} \mathrm{Hf}_{0.07} \mathrm{Al}_{0.03} \mathrm{Fe}_{0.05}\right) \mathrm{O}_{6.63}$, maintaining the Ce/Gd ratio $(\sim 1)$ of the starting materials. Hafnolite, with the structural formula $\left(\mathrm{Ca}_{0.60} \mathrm{Ce}_{0.14} \mathrm{Gd}_{0.24}\right.$ $\left.\mathrm{U}_{0.02}\right)\left(\mathrm{Al}_{0.13} \mathrm{Fe}_{0.31} \mathrm{Hf}_{0.47} \mathrm{U}_{0.10}\right)\left(\mathrm{Al}_{0.16} \mathrm{Ti}_{1.84}\right) \mathrm{O}_{6.76}$, is stabilized through incorporation of both $\mathrm{Fe}$ and $\mathrm{Al}$ at the $\sim 3.5 \mathrm{wt} \%$ and the $\sim 5 \mathrm{wt} \%$ levels, respectively (Table 13). This is not unexpected since both $\mathrm{Fe}$ and $\mathrm{Al}$ alone stabilize hafnolite. Both pyrochlore and hafnolite have less than 7 oxygens per 4 cations when calculated on the basis of $\mathrm{Fe}^{+2}, \mathrm{Ce}^{+3}$ and $\mathrm{U}^{+4}$.

If we assume $\mathrm{Fe}^{+3}, \mathrm{Ce}^{+4} / \Sigma \mathrm{Ce}=0.33$, ideal stoichiometries for pyrochlore and hafnolite are obtained for $\mathrm{UO}_{2.7}$ and $\mathrm{UO}_{2.51}$, respectively at $1350^{\circ} \mathrm{C}$. These values are indistinguishable from those obtained in the $\mathrm{Al}$ - and $\mathrm{Fe}$-doped runs suggesting that the $\mathrm{Fe}$ valence in all runs is $\mathrm{Fe}^{+3}$.

Stewart et al. (1999) have added $\mathrm{Fe}$ and $\mathrm{Al}$ together with $\mathrm{Cr}, \mathrm{Mn}$ and $\mathrm{Ga}$ to both $\mathrm{Ce}-$ analog and $\mathrm{Pu}$-bearing formulations. In air and $\mathrm{Ar}$ at $1350^{\circ} \mathrm{C}$ loveringite was the saturating accessory phase enriched in both Fe and Al. The chemically more complex loveringite,

$$
\left(\mathrm{Ca}_{2.1} \mathrm{Gd}_{0.35} \mathrm{Hf}_{0.73} \mathrm{U}_{0.45} \mathrm{Ce}_{0.45}\right)\left(\mathrm{Al}_{3.02} \mathrm{Cr}_{1.67} \mathrm{Mn}_{0.81} \mathrm{Fe}_{1.74} \mathrm{Ga}_{4.16} \mathrm{Ti}_{7.5}\right) \mathrm{O}_{23}
$$

is clearly stabilized by the presence of $\mathrm{Ga}, \mathrm{Cr}, \mathrm{Mn}$, etc. In the absence of additional di- and trivalent cations we observe $\mathrm{Fe}-\mathrm{Al}$ psuedobrookite $\left(\mathrm{Al}_{1.6} \mathrm{Fe}_{0.4}\right) \mathrm{TiO}_{5}$ which is free of $\mathrm{Ce}, \mathrm{Gd}$ and $\mathrm{U}$. In more complex compositions the effect of $\mathrm{Fe}-\mathrm{Al}$ additions will depend upon the other cations present and the chemical durability of phases like loveringite.

\subsubsection{The baseline assemblage with $10 \mathrm{wt} \% \mathrm{MgAl}_{2} \mathrm{O}_{4}$}

At $1300^{\circ} \mathrm{C}$ and $1350^{\circ} \mathrm{C}$ the addition of $10 \mathrm{wt} \% \mathrm{MgAl}_{2} \mathrm{O}_{4}$ yields assemblages containing pyrochlore and Mg-psuedobrookite (Table 2, 3 and C11, Plate 8). Hafnolite is also found in the $1300^{\circ} \mathrm{C}$ experiment and contains $\sim 1.5 \mathrm{wt} \% \mathrm{MgO}$. Pyrochlore contains less than 1 wt $\%$ MgO, and has the structural formula 
$\left(\mathrm{Ca}_{0.98} \mathrm{Ce}_{0.25} \mathrm{Gd}_{0.22} \mathrm{U}_{0.37}\right)\left(\mathrm{Ti}_{1.90} \mathrm{Hf}_{0.16} \mathrm{Al}_{0.03} \mathrm{Mg}_{0.09}\right) \mathrm{O}_{6.68}$ with the nominal $\mathrm{Ce} / \mathrm{Gd}$ ratio of the starting material.

Mg-psuedobrookite, $\mathrm{Mg}_{0.5} \mathrm{Al}_{1.0} \mathrm{Ti}_{1.5} \mathrm{O}_{5}$, like the Fe-psuedobrookite from the previous section has virtually no $\mathrm{Ce}$ or $\mathrm{Gd}$, but does contain $\mathrm{HfO}_{2}$ at the $\sim 3$ wt\% level. $\mathrm{Mg}-\mathrm{Al}$ psuedobrookite clearly buffers the $\mathrm{Mg}$ content of pyrochlore at a lower value than $\mathrm{Mg}_{2} \mathrm{TiO}_{4}$ or $\mathrm{MgTiO}_{3}$ in the $\mathrm{MgO}$-doped runs. As such, the Ti-site has $\sim 1.9 \mathrm{Ti}$ per 4 cations requiring little $\mathrm{Mg}$ on the Ti-site, which precludes a charge deficiency on this site. This is reflected in lower $\mathrm{UO}_{\mathrm{x}}$ values, $\mathrm{x}=2.76$.

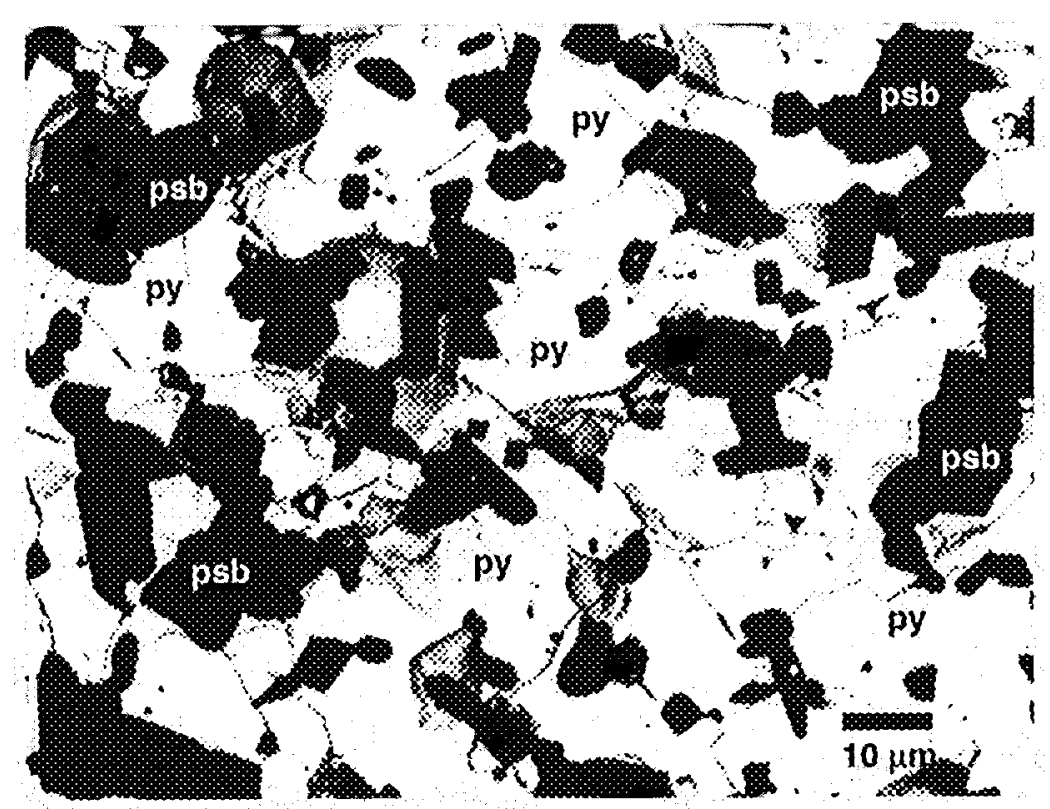

Plate 8. Backscattered electron image of baseline formulation with $10 \mathrm{wt} \% \mathrm{MgAl}_{2} \mathrm{O}_{4}$ added. Sintered at $1350^{\circ} \mathrm{C}$ in air (12/1). Phase assemblage includes pyrochlore (py) and psuedobrookite $(\mathrm{psb})$

\subsubsection{The baseline assemblage with $10 \mathrm{wt} \% \mathrm{CaAl}_{2} \mathrm{O}_{4}$}

As is the case with the addition of $\mathrm{Al}_{2} \mathrm{O}_{3}$ alone, the addition of $\mathrm{CaAl}_{2} \mathrm{O}_{4}$ to the baseline formulation leads to the stabilization of hafnolite and a number of aluminate phases (Table 2, 3, C12, Plate 9). Pyrochlore is present in all runs and has the structural formula $\left(1350^{\circ} \mathrm{C}\right)\left(\mathrm{Ca}_{1.13} \mathrm{Ce}_{0.22} \mathrm{Gd}_{0.18} \mathrm{Hf}_{0.11} \mathrm{U}_{0.36}\right)\left(\mathrm{Al}_{0.03} \mathrm{Hf}_{0.03} \mathrm{Ti}_{1.95}\right) \mathrm{O}_{6.6}$. Hafnolite is also present in runs 
conducted at both $1300^{\circ} \mathrm{C}$ and $1350^{\circ} \mathrm{C}$ and contains $\sim 3.5 \mathrm{wt} \% \mathrm{Al}_{2} \mathrm{O}_{3}$. Brannerite does not appear in any of these runs, which may be a result of the increased Ca concentration.

The elevated $\mathrm{Ca}$ activity is apparent in the pyrochlore chemistry which has greater than $1 \mathrm{Ca}$ per 4 cations in these materials. Like the addition of other divalent cations, addition of $\mathrm{Ca}$ to the A-site in pyrochlore requires oxidation of uranium or cerium to maintain stoichiometry, reflected here as $\mathrm{UO}_{2.85}$ assuming $\mathrm{Ce}^{+4} / \Sigma \mathrm{Ce}=0.33$.

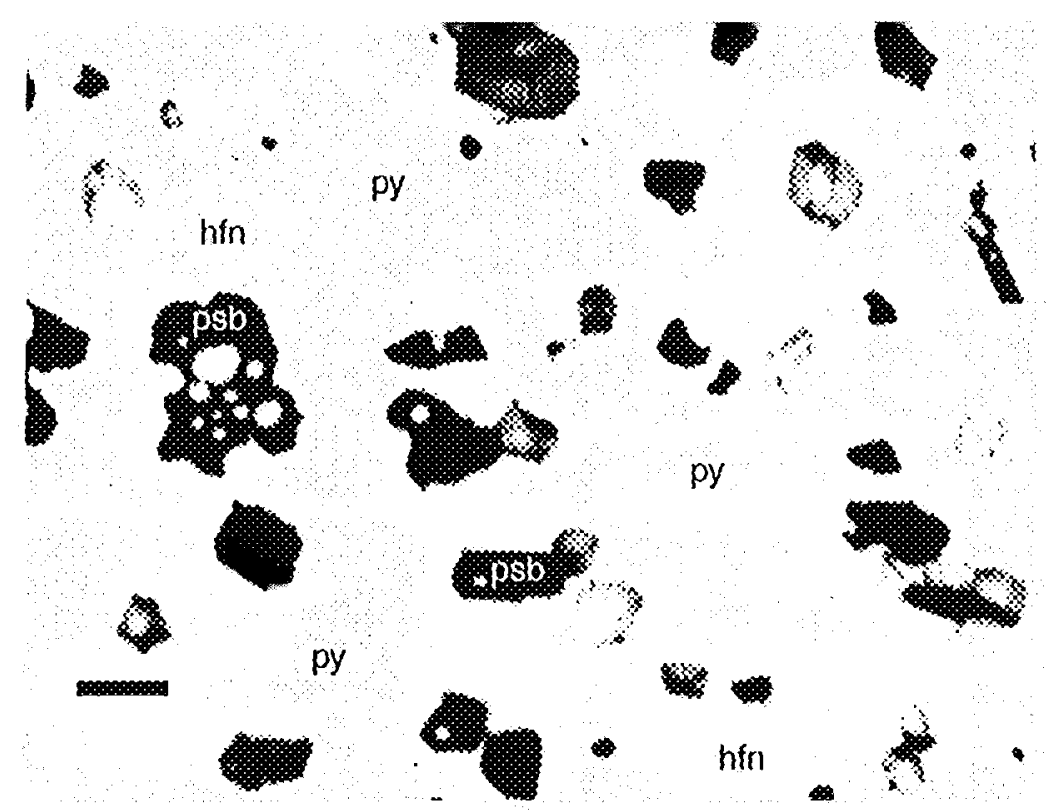

Plate 9. Backscattered electron image of baseline formulation with $10 \mathrm{wt} \% \mathrm{CaAl}_{2} \mathrm{O}_{4}$ added. Sintered at $1350^{\circ} \mathrm{C}$ in air (13/1). Phase assemblage includes pyrochlore (py) and hafnolite (hfn) and psuedobrookite (psb).

The aluminate assemblage varies with temperature (Table 2). At $1300^{\circ} \mathrm{C}$ corundum and rutile coexist with a calcium-lanthanide aluminotitanate. At $1350^{\circ} \mathrm{C}$ the calciumlanthanide aluminotitanate (CTA) is the only Al-rich phase present. The nominal CTA stoichiometry is 12 cations/19 oxygens, $\left(\mathrm{Ca}_{0.76} \mathrm{Ce}_{2.35} \mathrm{Gd}_{0.04}\right)\left(\mathrm{Al}_{8.2} \mathrm{Ti}_{275}\right) \mathrm{O}_{19}$ (in the $1350^{\circ} \mathrm{C}$ experiment) and is similar to the magnetoplumbite structure analogs found in wasteforms formulated for US Defense wastes (Ryerson, 1984, Morgan et al., 1981). Unlike many of the titanate phases encountered here, CTA appears to preferentially incorporate the light lanthanide elements, and contains little gadolinium $(<1 \mathrm{wt} \%)$. CTA also contains no 
uranium. If cerium is an adequate analog for plutonium in this phase, then these results indicate that a Pu-bearing phase with virtually no neutron absorbers will be produced by the addition of calcium and aluminum together. In this connection, Stewart et al. (1999) found no detectable $\mathrm{Pu}$ in magnetoplumbite in a Pu-bearing formulation with enriched levels of $\mathrm{Al}, \mathrm{Cr}, \mathrm{Mn}, \mathrm{Fe}$ and $\mathrm{Ga}$ synthesized in air at $1350^{\circ} \mathrm{C}$. The compositions required to eliminate CTA from the wasteform can be estimated using the compositions of pyrochlore and hafnolite from our $1350^{\circ} \mathrm{C}$ run. For instance a CTA-free material with $10 \mathrm{wt} \%$ hafnolite and $90 \%$ pyrochlore would have an $\mathrm{Al}_{2} \mathrm{O}_{3} / \mathrm{PuO}_{2}$ ratio of $0.13 ; 20 \%$ hafnolite and $80 \%$ pyrochlore yields $\mathrm{Al}_{2} \mathrm{O}_{3} / \mathrm{PuO}_{2}=0.21$.

\subsubsection{The baseline assemblage with $10 \mathrm{wt} \% \mathrm{MoO}_{3}$}

A single experiment conducted in air at $1350^{\circ} \mathrm{C}$ to which $10 \mathrm{wt} \% \mathrm{MoO}_{3}$ was added (Table 2, 3, C13) resulted in the assemblage pyrochlore-brannerite and the Ca-molybdate, powellite. The Ca-molybdate is nominally $\mathrm{CaMoO}_{4}$ which contains $\sim 1$ wt $\%$ each $\mathrm{CeO}_{2}$ and $\mathrm{Gd}_{2} \mathrm{O}_{3}$ and insignificant uranium. Molybdenum is also slightly soluble in pyrochlore and contains $1.73 \mathrm{wt} \%$ and has the structural formula, $\mathrm{Ca}_{1.06} \mathrm{Ce}_{0.21} \mathrm{Gd}_{0.26} \mathrm{Hf}_{0.12} \mathrm{U}_{0.36}\left(\mathrm{Ti}_{1.81} \mathrm{Hf}_{0.13} \mathrm{Mo}_{0.06}\right) \mathrm{O}_{6.76}$. The number of $\mathrm{Ti}$ cations/4 total cations, 1.81 , is lower than that in the baseline assemblage, $\sim 1.9$, and is likely due to the incorporation of Mo on the Ti-site. Substitution of $\mathrm{Mo}^{+6}$ for Ti results in excess charge on the Ti-site. This can be balanced by reduction in the valence of $\mathrm{Ce}$ and $\mathrm{U}$ on the A-site. As such the valence of uranium here is $\mathrm{UO}_{2.57}$. Brannerite contains negligible molybdenum.

The composition of a $\mathrm{CaMoO}_{4}$-free assemblage is fixed by the solubility of $\mathrm{Mo}$ in pyrochlore. The molar ratio $\mathrm{MoO}_{4} / \mathrm{CeO}_{2}$ in this pyrochlore is 0.27 ; at higher Mo contents, a molybdate is likely to form. However, since the phase contains little of the plutoniumanalog element, Ce, it is unlikely to degrade the durability of the waste form. 


\subsubsection{The baseline assemblage with $10 \mathrm{wt} \% \mathrm{WO}_{3}$}

The addition of $10 \mathrm{wt} \% \mathrm{WO}_{3}$ to the baseline assemblage has an effect similar to that of $\mathrm{MoO}_{3}$, resulting in the stabilization of scheelite, $\mathrm{CaWO}_{4}$, coexisting with rutile, brannerite and pyrochlore at $1350^{\circ} \mathrm{C}$ in air (Table 2, 3, C14). However, unlike molybdenum, tungsten has significant solubility in pyrochlore which contains $14.37 \mathrm{wt} \% \mathrm{WO}_{3}$. Stewart et al. (1999) observed a similar preference of pyrochlore for tungsten relative to molybdenum in experiments where pyrochlore coexisted with a powellite-scheelite solid solution. The pyrochlore structural formula is $\left(\mathrm{Ca}_{1.08} \mathrm{Ce}_{0.19} \mathrm{Gd}_{0.22} \mathrm{Hf}_{0.15} \mathrm{U}_{0.36}\right)\left(\mathrm{Ti}_{1.68} \mathrm{Hf}_{0.02} \mathrm{~W}_{0.31}\right)$ $\mathrm{O}_{7.02}$. Unlike many of the pyrochlores discussed above, the Ti content of this pyrochlore is well below that of the baseline, and the number of oxygens/4 cations is close to the ideal stoichiometry of 7. The low Ti content is due to the incorporation of $\mathrm{W}$ on the Ti-site. The ideal stoichiometry is obtained by casting uranium as $\mathrm{U}^{+4}$ and $\mathrm{Ce}$ as $\mathrm{Ce}^{+3}$. The apparent reduction of uranium and cerium is the result of the excess charge on the Ti-site resulting from the exchange of $\mathrm{W}^{+6}$ for $\mathrm{Ti}^{+4}$. This is balanced by a charge deficit on the B-site which can be achieved by reduction of uranium. The presence of rutile in this sample compared to its absence in the Mo-doped runs is also a product of tungsten occupying the Ti-site in pyrochlore. This produces excess Ti which stabilizes rutile. Brannerite also incorporates some tungsten (Table C14).

The high concentrations of tungsten in pyrochlore allow very loose limits to be placed on the amount of tungsten that can be safely incorporated in the ceramic. $\mathrm{A}^{\mathrm{W}} \mathrm{WO}_{3} / \mathrm{CeO}_{2}$ ratio of 1.68 would yield a $\mathrm{CaWO}_{3}$-free ceramic containing only pyrochlore.

\subsubsection{The baseline assemblage with $10 \mathrm{wt} \% \mathrm{P}_{2} \mathrm{O}_{5}$}

Phosphorus, a potential glass-former, was added to the baseline formulation at the 10 wt\% level and sintered at $1300^{\circ} \mathrm{C}, 1350^{\circ} \mathrm{C}$ and $1400^{\circ} \mathrm{C}$ (Table 2, 3, C15; Plate 10). $\mathrm{P}_{2} \mathrm{O}_{5}$ has a profound effect on the wasteform mineralogy at these concentration levels, eliminating the characteristic phase, pyrochlore, from the assemblage. Instead, the 
assemblage found in these compositions is brannerite - rutile - Ca-lanthanide-phosphate (CLP) \pm phosphate glass. The phosphate glass clearly penetrates the grain edge junctions of the coexisting solid phases at each temperature. Ca-lanthanide-phosphate, CLP, has the nominal formula $\mathrm{Ca}_{6.2} \mathrm{Ce}_{0.4} \mathrm{Gd}_{0.4} \mathrm{Ti}_{0.2} \mathrm{P}_{4.8} \mathrm{O}_{20}$. CLP is missing from the assemblage at $1400^{\circ} \mathrm{C}$, indicating that the CLP liquidus lies between $1350^{\circ} \mathrm{C}$ and $1400^{\circ} \mathrm{C}$.

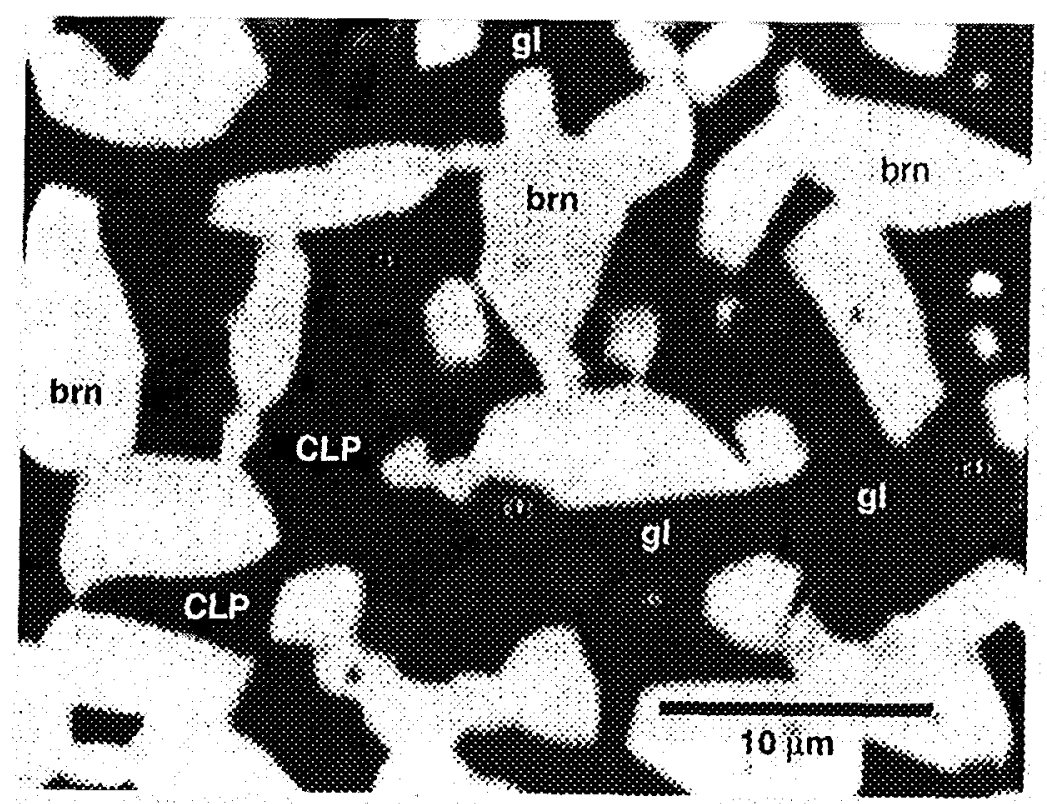

Plate 10. Backscattered electron image of baseline formulation with 10 wt $\% \quad \mathrm{P}_{2} \mathrm{O}_{5}$ added. Sintered at $1350^{\circ} \mathrm{C}$ in air (2/3). Phase assemblage includes brannerite (brn) and a calcium-lanthanide phosphate (CLP), rutile (ru) and phosphaste glass (gl).

In the absence of pyrochlore, the phosphorus-bearing phases become the major hosts for the $\mathrm{Pu}$-analog element, cerium. The phosphate glass contains $16-18 \mathrm{wt} \% \quad \mathrm{Ce}_{2} \mathrm{O}_{3}$ compared with $\sim 7 \mathrm{wt} \%$ in brannerite and CLP. Both phosphorus-bearing phases have $\mathrm{Ce} / \mathrm{Gd}$ ratios close to unity, but are essentially devoid of uranium and hafnium which are largely concentrated in brannerite.

The effect of $\mathrm{P}_{2} \mathrm{O}_{5}$ addition can be represented by its reaction with the endmember pyrochlore components, $\mathrm{CaUTi}_{2} \mathrm{O}_{7}$ and $\mathrm{Ln}_{2} \mathrm{Ti}_{2} \mathrm{O}_{7}$ (where $\mathrm{Ln}$ is a lanthanide), 


$$
\begin{gathered}
6 \mathrm{CaUTi}_{2} \mathrm{O}_{7}+1 / 2 \mathrm{Ln}_{2} \mathrm{Ti}_{2} \mathrm{O}_{7}+2.5 \mathrm{P}_{2} \mathrm{O}_{5} \Leftrightarrow \mathrm{Ca}_{6} \mathrm{Ln}_{1} \mathrm{P}_{5} \mathrm{O}_{20}+6 \mathrm{UTi}_{2} \mathrm{O}_{6}+\mathrm{TiO}_{2} \\
(\mathrm{Py})+(\mathrm{Py})+\left(\mathrm{P}_{2} \mathrm{O}_{5}\right) \Leftrightarrow(\mathrm{CLP})+(\text { brn })+\text { (rut) }
\end{gathered}
$$

in which $\mathrm{P}_{2} \mathrm{O}_{5}$ reacts with pyrochlore to form CLP and additional brannerite. The reaction demonstrates that each mole of $\mathrm{P}_{2} \mathrm{O}_{5}$ consumes more than twice as many moles of pyrochlore. In these experiments the amount of $\mathrm{P}_{2} \mathrm{O}_{5}$ added was sufficient to consume all of the pyrochlore present. Smaller $\mathrm{P}_{2} \mathrm{O}_{5}$ additions would result in a pyrochlore-branneriterutile-CLP $\pm \mathrm{P}$-glass assemblage. However, the due to the absence of pyrochlore in these runs, we are unable to determine the $\mathrm{P}_{2} \mathrm{O}_{5}$ concentration in pyrochlore when it coexist $\mathrm{s}$ with a phosphorus-rich accessory mineral. However, $\mathrm{P}_{2} \mathrm{O}_{5}$ in phosphorus-rich-accessory mineral-saturated brannerite is below detection. Assuming that pyrochlore concentrates similar quantities of $\mathrm{P}_{2} \mathrm{O}_{5}$, yields the conservative approximation that any addition of $\mathrm{P}_{2} \mathrm{O}_{5}$ will result in the stabilization of a phosphorus-rich accessory mineral. This is supported by the work of Stewart et al. (1999) who were unable to detect $\mathrm{P}_{2} \mathrm{O}_{5}$ in pyrochlore, hafnolite and brannerite coexisiting with a silicate that contained $3 \mathrm{wt} \% \mathrm{P}_{2} \mathrm{O}_{5}$.

\subsubsection{The baseline assemblage with $10 \mathrm{wt} \% \mathrm{SiO}_{2}$}

The addition of $\mathrm{SiO}_{2}$ at the $10 \mathrm{wt} \%$ level also results also results in a pyrochlore-free assemblage at $1300^{\circ} \mathrm{C}$ and $1350^{\circ} \mathrm{C}$ (Table 2,3, C16). Here the absence of pyrochlore is explained by its dissolution in a compositionally unusual high- $\mathrm{TiO}_{2}$ silicate glass. The glass contains only $15 \mathrm{wt} \% \mathrm{SiO}_{2}$ and $32 \mathrm{wt} \% \mathrm{TiO}_{2}$. In addition the glass is high in lanthanides, hafnium and uranium (Table C16). The conesiting brannerite is slightly higher in $\mathrm{HfO}_{2}$ than the baseline run products, but otherwise very similar. Neither brannerite nor rutile contain detectable $\mathrm{SiO}_{2}$. 


\subsubsection{The baseline assemblage with 10 and $20 \mathrm{wt} \% \mathrm{NaAlSiO}_{4}$}

Sodium is a difficult element to immoblize in a titanate assemblage, typically requiring the addition of pentavlent cations such as niobium to allow coupled substitution such as,

$$
\mathrm{Na}+\mathrm{Nb} \Leftrightarrow \mathrm{Ca}+\mathrm{Ti}
$$

which promote sodium incorporation in titanate minerals (cf, Vance et al., 1991). The alternative is to add silica and alumina to fix sodium as an alkali alumino-silicate mineral and/or glass, as proposed for the immobilization of Savannah River wastes in a Synroc assemblage (Ryerson, 1984). The component phases of Synroc are not stable in assemblages with high silica activity, (e.g., in equilibrium with quartz, cf, Nesbitt et al, 1981). Since, nepheline, $\mathrm{NaAlSiO}_{4}$ is also unstable in assemblages with high silica activities, it is a reasonable component to use in simulating the effects of alkali aluminosilicate additions to this $\mathrm{Pu}$-disposition ceramic. Here, in an attempt to generate sufficient quenched melt to analyze with the electron probe, we have prepared starting materials with 10 and $20 \mathrm{wt} \% \mathrm{NaAlSiO}_{4}$ (Table 2, 3, $\mathrm{C17}$ and $\mathrm{C} 18$ ).

Samples containing $10 \mathrm{wt} \% \mathrm{NaAlSiO}_{4}$ result in pyrochlore-rutile-melt assemblages at $1300^{\circ} \mathrm{C}$ and $1350^{\circ} \mathrm{C}$ (Plate 11). These samples also contain small $(\sim 1 \times 10 \mu \mathrm{m})$ laths of hafnolite (Plate 12). The hafnolite is euhedral and in spite of its size relative to the coexisting pyrochlore and rutile appears to be a part of the stable phase assemblage. Dendritic quench crystals are also obvious in some parts of the sample (Plate 12). With the addition of $20 \mathrm{wt} \% \mathrm{NaAlSiO}_{4}$, rutile is no longer present, and the quenched assemblage consists of pyrochlore and hafnolite. These phases coexist with quenched melt containing abundant dendritic quench crystals (Plate 12). 


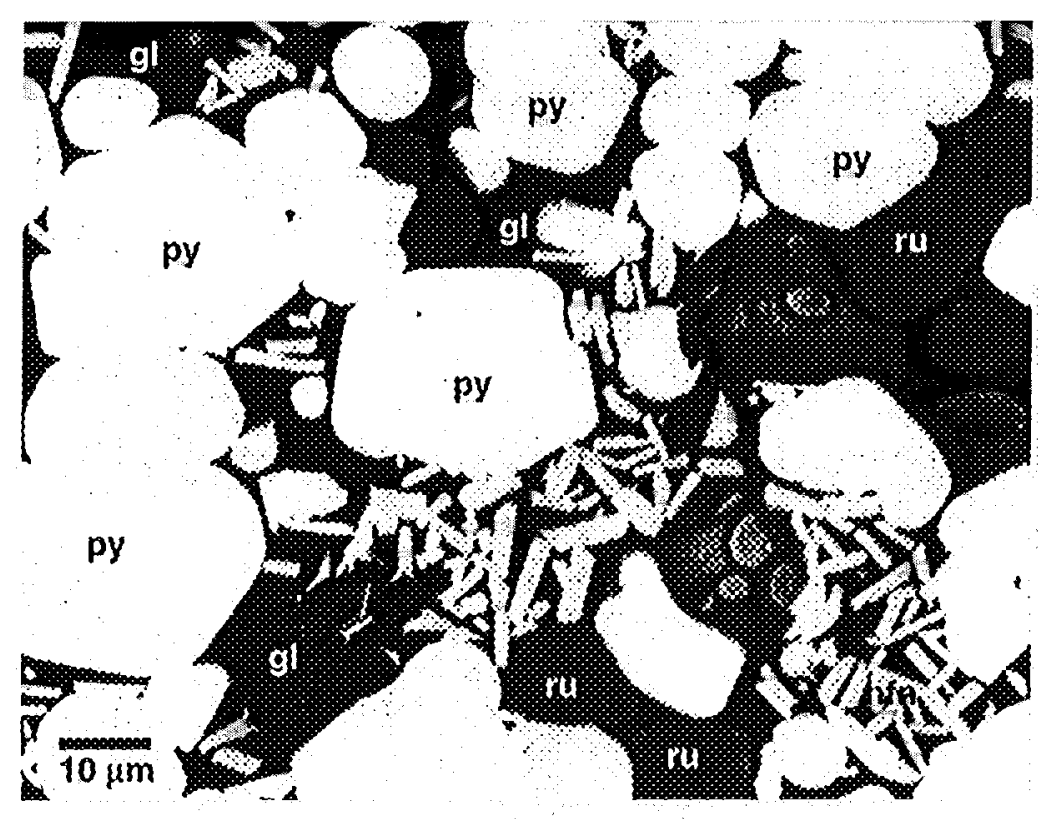

Plate 11. Backscattered electron image of baseline formulation plus $10 \mathrm{wt} \% \mathrm{NaAlSiO}_{4}$ sintered at $1350^{\circ} \mathrm{C}$ in air (15/1). Phase assemblage contains pyrochlore (py), hafnolite (hfn, as small laths) rutile (ru) and silicate glass (gl).

The pyrochlore composition is relatively consistent among these 4 experiments, although different from that in the baseline assemblage, as it contains $\sim 1 \mathrm{wt} \% \mathrm{Na}_{2} \mathrm{O}$. The nominal structural formula for these pyrochlores is $\mathrm{Na}_{0.14} \mathrm{Ca}_{0.89} \mathrm{Ce}_{0.25} \mathrm{Gd}_{0.24} \mathrm{Hf}_{0.1} \mathrm{U}_{0.38}\left(\mathrm{Ti}_{1.87} \mathrm{Hf}_{0.12}\right) \mathrm{O}_{6.65}$ compared to that in the baseline material, $\mathrm{Ca}_{1.04} \mathrm{Ce}_{0.23} \mathrm{Gd}_{0.23} \mathrm{Hf}_{0.21} \mathrm{U}_{0.39}\left(\mathrm{Ti}_{1.89} \mathrm{Al}_{.01}\right) \mathrm{O}_{6.7}$. Based upon the decreased calcium content of the Na-bearing pyrochlore, it appears that sodium replaces calcium in the structure. Given the similarity in the other cation concentrations, the exact substitution is difficult to determine. It is possible that $\mathrm{Na}$ is accommodated through a change in the oxidation state of either cerium or uranium,

$$
\begin{aligned}
& \mathrm{Na}^{+}+\mathrm{U}^{+5} \Leftrightarrow \mathrm{Ca}^{+2}+\mathrm{U}^{+4} \\
& \text { or } \\
& \mathrm{Na}^{+}+\mathrm{Ce}^{+4} \Leftrightarrow \mathrm{Ca}^{+2}+\mathrm{Ce}^{+3}
\end{aligned}
$$


Values of $\mathrm{UO}_{\mathrm{x}}$ are all more oxidized than $\mathrm{UO}_{2.8}$ which is consistent with these reactions (Table $\mathrm{C} 17$ and $\mathrm{C} 18$ ). None of the pyrochlores contains detectable $\mathrm{SiO}_{2}$, and the $\mathrm{Ce} / \mathrm{Gd}$ ratios are all close to unity, the same as the ratio in the starting material.

The hafnolites contain $\sim 2.5-3.0$ wt $\% \mathrm{Al}_{2} \mathrm{O}_{3}$. This is slightly lower than the $\mathrm{Al}_{2} \mathrm{O}_{3}$ concentrations in hafnolites from the experiments in which they coexist with corundum or Al-psuedobrookite (section 4.1.2). Like the other hafnolites observed, the lanthanides are fractionated with a $\mathrm{Ce} / \mathrm{Gd}$ ratio of $\sim 0.5$.

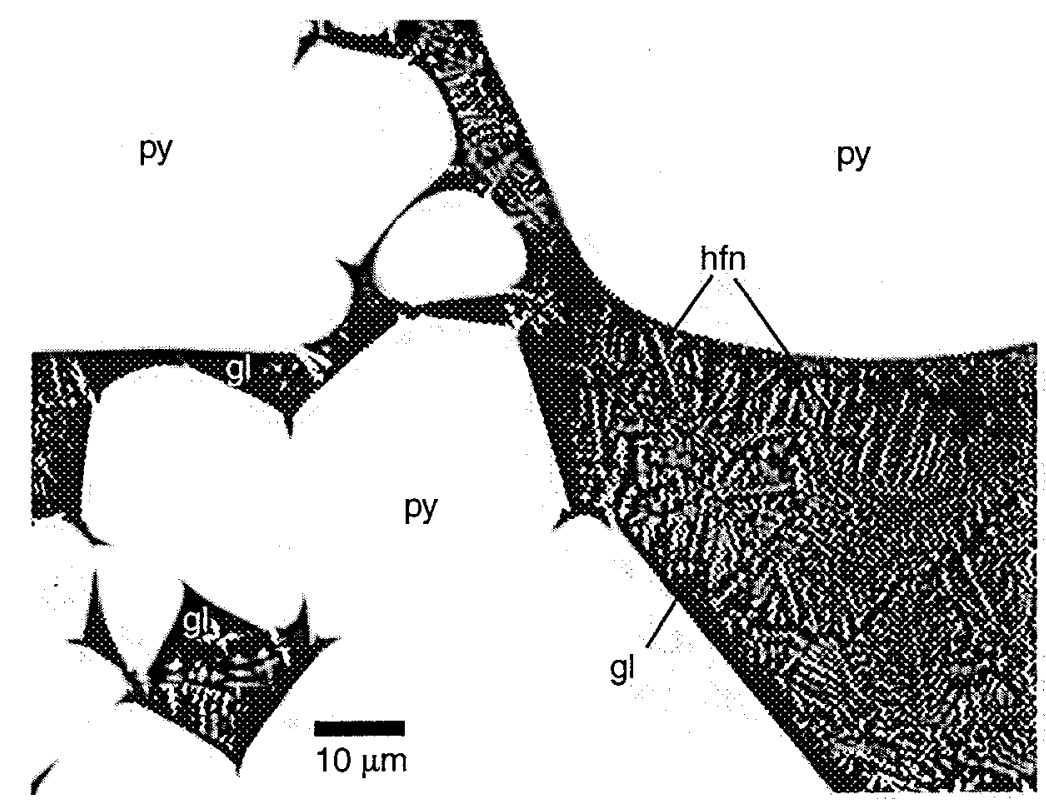

Plate 12. Backscattered electron image of baseline formulation plus $20 \mathrm{wt} \% \mathrm{NaAlSiO}_{4}$ sintered at $1350^{\circ} \mathrm{C}$ in air (16/1). Phase assemblage contains pyrochlore (py), hafnolite (hfn, as small quench crystals), and silicate glass (gl).

Analysis of the glass phase is complicated by the presence of quench material (Plate 12). This is especially true for the samples containing $20 \mathrm{wt} \% \mathrm{NaAlSiO}_{4}$ (Plate 12). Nevertheless, by focussing analyses on regions with low concentrations of quench crystals, clear trends in melt composition as a function of temperature are revealed. The glass composition at $1350^{\circ} \mathrm{C}$ is rather unusual, containing only $15 \mathrm{wt} \% \mathrm{SiO}_{2}$ and $43 \mathrm{wt} \% \mathrm{TiO}_{2}$ (Table C18). The $1350^{\circ} \mathrm{C}$ glass also contains significant amounts of $\mathrm{Ce}, \mathrm{Gd}, \mathrm{Hf}$ and $\mathrm{U}$. Relative to the $1350^{\circ} \mathrm{C}$ glass composition, that of the $1300^{\circ} \mathrm{C}$ run is higher in $\mathrm{Na}, \mathrm{Al}$, and 
$\mathrm{Si}$, but lower in $\mathrm{Ti}, \mathrm{Ce}, \mathrm{Gd}, \mathrm{Hf}$ and $\mathrm{U}$. The Ce/Gd ratio is $>2$ in the glass, reflecting the strong factionation of the lanthanides by hafnolite. Partition coefficients between pyrochlore and melt, $\mathrm{D}^{\mathrm{py} / \mathrm{melt}}(=\mathrm{wt} \%$ in pyrochlore/wt\% in melt) are less than unity for $\mathrm{Na}$, $\mathrm{Al}$ and $\mathrm{Si}$, and greater than unity for $\mathrm{Ce}, \mathrm{Gd}, \mathrm{Hf}$ and $\mathrm{U}(\mathrm{Ti}$ is complicated by the appearance of rutile which buffers its concentration in the melt). The compositional trends with temperature are exactly what one would predict from simple mineral-melt fractionation - depletion of pyrochlore-compatible elements and the enrichment of pyrochlore-incompatible elements. Most importantly, the trend indicates that the silicate melt will become increasingly depleted in radionuclide and neutron absorbers during slow cooling and continued crystallization of the melt. Analysis of the melt compositions from the $20 \mathrm{wt} \% \mathrm{NaAlSiO}_{4}$ runs leads to identical conclusions.

Much like the silicate melt bearing materials described in section $4.1 .15\left(10 \mathrm{wt} \% \mathrm{SiO}_{2}\right.$ added to the baseline formulation), the titanate phase assemblage is incapable of accommodating more than trace levels of silica, and at least in these "quench experiments" we have not observed silicate mineral phases such as titanite, $\mathrm{CaTiSiO}_{5}$, that could conceivably coexist with Ti-rich mineral assemblages. Given the proposed processing conditions (Ebbinghaus et al., 1999), any silica in the wasteform will result in the presence of a silicate melt during sintering. The compositional evolution of this melt during cooling observed here suggests that the eventual glass phase may be low in radionuclides and neutron absorbers, however, and may not have a deleterious effect on the chemical durability of the form. Time-temperature-transformation studies of the melt composition and crystallization are needed to validate and quantify these effects.

Interestingly, in the absence of silica, this titanate assemblage can accommodate sodium without the addition of pentavalent cations such as niobium or tantalum. This is facilitated by charge-transfer reactions involving uranium and cerium (and presumably $\mathrm{Pu}$ in the full radioactive equivalent of the Ce-analogs). Using the pyrochlore composition 
from run 15-1, the molar $\mathrm{Na}_{2} \mathrm{O} / \mathrm{PuO}_{2}$ limit precluding the formation of an accessory phase is 0.29 .

\subsubsection{The baseline assemblage with added calcium}

$\mathrm{CaO}$ is a major component of the wasteform. However, the activity of $\mathrm{CaO}$ is not buffered by a specific phase as is the case for $\mathrm{TiO}_{2}$, which is fixed by the presence of rutile in the baseline assemblage. While addition of $\mathrm{TiO}_{2}$ will result in more modal rutile, variations in $\mathrm{CaO}$ concentration will qualitatively change the phase assemblage (Table 2, 3). This is clearly the case in experiments where $10 \mathrm{wt} \% \mathrm{CaO}$ was added to the baseline and results in the phase assemblage pyrochlore and perovskite (Plate 13) at $1300^{\circ} \mathrm{C}, 1350^{\circ} \mathrm{C}$ and $1400^{\circ} \mathrm{C}$. Neither rutile nor brannerite is observed in any of the runs.

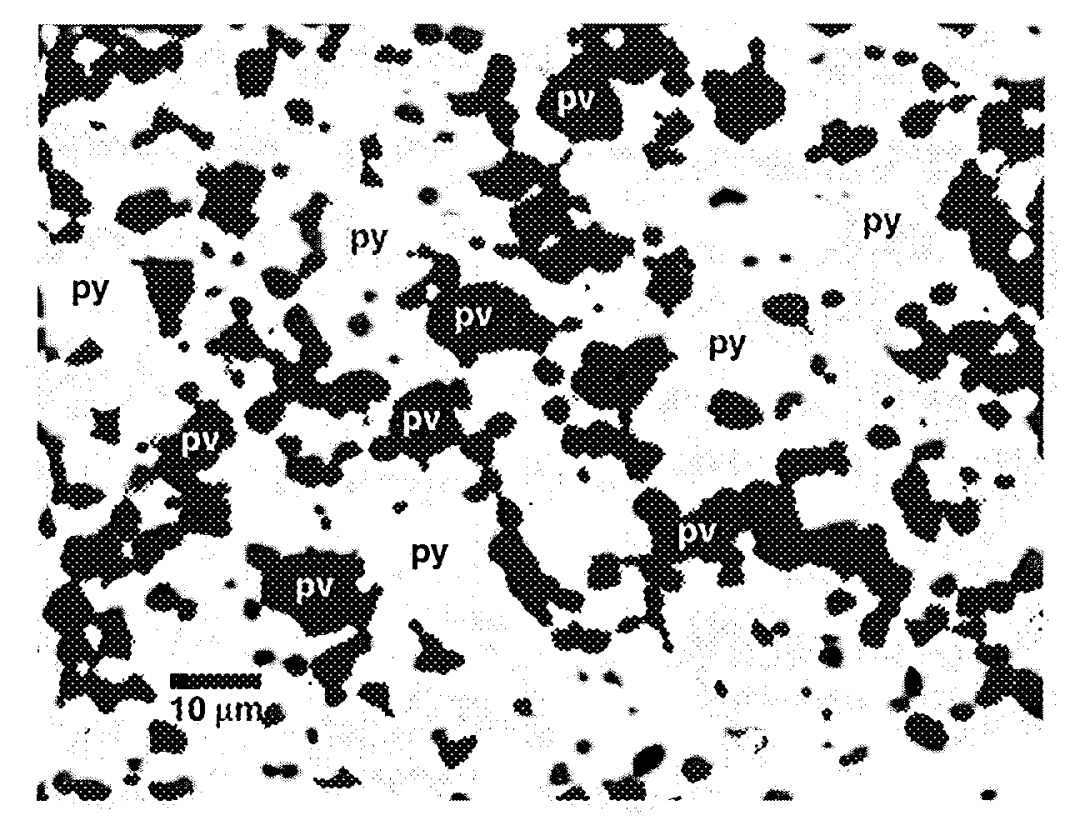

Plate 13a. Backscattered electron image of baseline formulation plus $10 \mathrm{wt} \% \mathrm{CaO}$ sintered at $1350^{\circ} \mathrm{C}$ in air (3/3). Phase assemblage contains pyrochlore (py), perovskite (pv).

The qualitative changes observed in the phase assemblage due to variations in the activity of $\mathrm{CaO}$ are also reflected in quantitative changes in the pyrochlore chemistry (Table C19). For instance, the structural formula for the pyrochlore in the $1350^{\circ} \mathrm{C}$ run on the CaO-doped material is $\mathrm{Ca}_{1.21} \mathrm{Ce}_{0.20} \mathrm{Gd}_{0.19} \mathrm{U}_{0.43}\left(\mathrm{Ti}_{1.58} \mathrm{Hf}_{0.39} \mathrm{Al}_{0.1}\right) \mathrm{O}_{6.59}$ compared to 
$\mathrm{Ca}_{1.04} \mathrm{Gd}_{0.23} \mathrm{Hf}_{0.11} \mathrm{U}_{0.39} \mathrm{Ce}_{0.23}\left(\mathrm{Ti}_{1.89} \mathrm{Hf}_{0.10} \mathrm{Al}_{.01}\right) \mathrm{O}_{6.7}$ in the undoped baseline material at the same temperature. The number of $\mathrm{Ca}$ per 4 total cations exceeds the more typical value of $\sim 1$ in most other runs. As the overall structural formula for pyrochlore, $\mathrm{A}_{2} \mathrm{Ti}_{2} \mathrm{O}_{7}$, possesses 2 equivalent A-sites there is no structural constraint precluding more than one $\mathrm{Ca}$ per formula unit. Rather, in these high variance assemblages, the typical single Ca per formula unit reflects the bulk composition rather than a limit imposed by phase equilibria or crystal chemistry. The Ce/Gd molar ratio in pyrochlore remains close to unity in all runs, despite the change in the Ca-content. The high $\mathrm{Ca}$ content is also reflected in uranium valences greater that $\mathrm{UO}_{2.87}$ (Table $\left.\mathrm{C} 19\right)$.

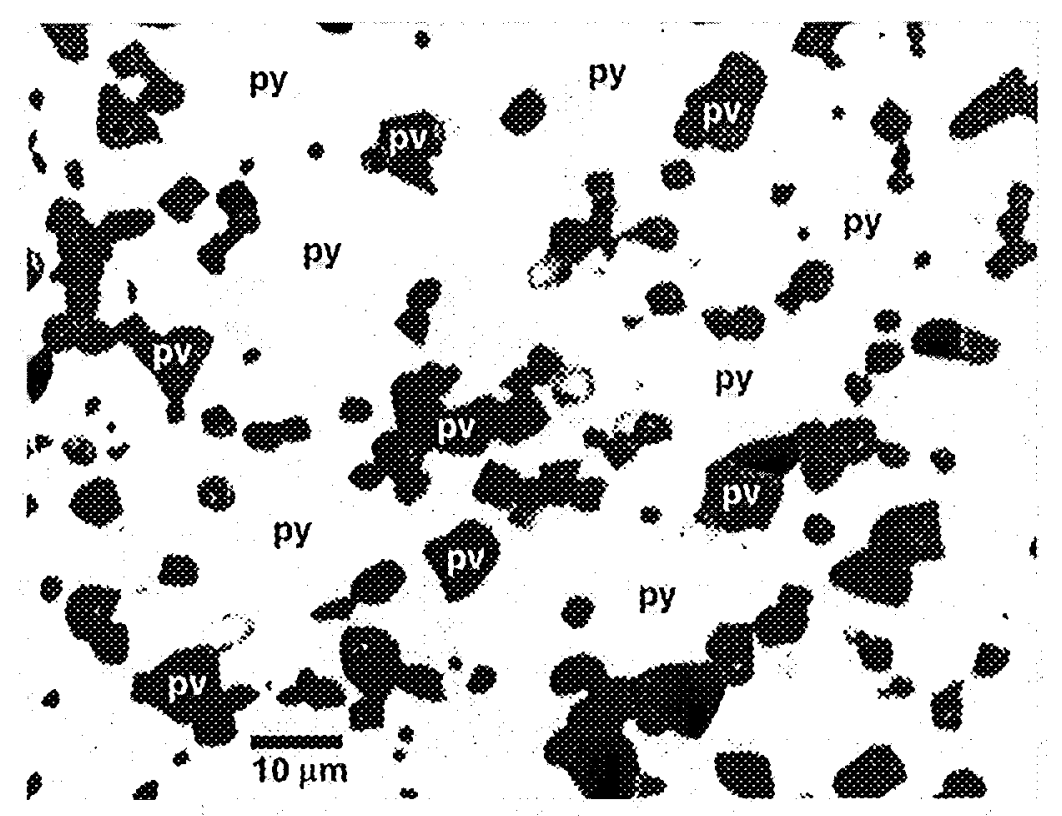

Plate 13b. Backscattered electron image of baseline formulation plus $10 \mathrm{wt} \% \mathrm{CaF}_{2}$ sintered at $1350^{\circ} \mathrm{C}$ in air (3/3). Phase assemblage contains pyrochlore (py), perovskite (pv).

Perovskite has somewhat lower lanthanide concentrations than the coexisting pyrochlore and is virtually free of uranium (Table $\mathrm{C} 19$ ). At $1350^{\circ} \mathrm{C}$ the nominal perovskite formula is $\left(\mathrm{Ca}_{0.87} \mathrm{Ce}_{0.06} \mathrm{Gd}_{0.05} \mathrm{Hf}_{0.01}\right) \mathrm{Ti}_{1.01} \mathrm{O}_{3.08}$. The excess oxygen (calculated for $\mathrm{Ce}^{+3}$ ) may indicate the presence of minor cation vacancies in these perovskites. 
Calcium was also added to the baseline formulation as $\mathrm{CaF}_{2}(10 \mathrm{wt} \%)$ in an attempt to saturate the assemblage in fluorite. Microprobe analysis failed to detect any fluorinebearing phase however, indicating that fluorine was lost due to volatilization at high temperature (Table $\mathrm{C} 20$ ). The primary phase assemblage in the $\mathrm{CaF}_{2}$-doped experiments is pyrochlore and perovskite, and is similar to those observed in $\mathrm{CaO}$-doped runs (Table 2). The only exception is the presence of hafnolite in the $1300^{\circ} \mathrm{C}(3 / 1$, Table $\mathrm{C} 20)$. In addition, $\mathrm{CaF}_{2}$ appears to have enhanced densification and grain growth relative to $\mathrm{CaO}$ (Plate 13), presumably resulting from rapid grain boundary transport due to the escaping molten or vapor phase.

The chemistry of pyrochlore in the $\mathrm{CaF}_{2}$-doped materials differs somewhat from those in the $\mathrm{CaO}$-doped samples. For instance, the structural formula for the pyrochlore produced in the $1350^{\circ} \mathrm{C} \quad \mathrm{CaF}_{2}$-doped experiment is $\mathrm{Ca}_{1.17}\left(\mathrm{Ce}_{0.19} \mathrm{Gd}_{0.17} \mathrm{Hf}_{0.11} \mathrm{U}_{0.38}\right)\left(\mathrm{Ti}_{1.83} \mathrm{Hf}_{0.16}\right) \mathrm{O}_{6.65}$. The Ca concentration is again greater than 1 as a result of increased $\mathrm{CaO}$-activity. However, the $\mathrm{Hf} / \mathrm{Ti}$ ratio of this pyrochlore is lower than that in the CaO-doped samples. As the compositions of the perovskites in both materials is essentially the same (Table $\mathrm{C} 19$ and $\mathrm{C} 20$ ), the variation in the $\mathrm{Hf} / \mathrm{Ti}$ ratio can only result in a change in bulk composition. However, the "as-made" compositions have the same Hf/Ti ratio (Table 1). The presence of hafnolite in some runs may resolve this paradox, if hafnolite nucleation was somehow enhanced by the presence of a fluorine-rich volatile phase early in the experiment. If this early hafnolite failed to re-equilibrate, it would effectively decrease the Hf/Ti ratio in the remainder of the sample. Comparison of the structural formulas for the $\mathrm{CaO}-$ and $\mathrm{CaF}_{2}$-doped runs demonstrates that the variation in this $\mathrm{Hf} / \mathrm{Ti}$ ratio is accommodated on the Ti-site, with the concentration of $\mathrm{Hf}$ on the Asite remaining constant. This observation may be valuable in predicting the change in pyrochlore chemistry with variations in $\mathrm{Hf} / \mathrm{Ti}$. 


\subsubsection{The baseline assemblage with $10 \mathrm{wt} \% \mathrm{MnO}_{2}$}

The addition of $\mathrm{MnO}_{2}$ to the baseline formulation also results in the stabilization of perovskite at the expense of brannerite and rutile (Tables 2 and C21, Plate 14). Unlike the addition of $\mathrm{CaO}$ in which $\mathrm{CaO}$ is concentrated in and thereby stabilizes perovskite, manganese is actually partitioned into pyrochlore (Table C21). At $1350^{\circ} \mathrm{C}$ the pyrochlore stoichiometry is $\left(\mathrm{Ca}_{0.72} \mathrm{Gd}_{0.19} \mathrm{Ce}_{0.19} \mathrm{Mn}_{0.46} \mathrm{Hf}_{0.12} \mathrm{U}_{0.34}\right)\left(\mathrm{Ti}_{1.87} \mathrm{Hf}_{0.12} \mathrm{Al}_{0.01}\right) \mathrm{O}_{6.62}$. Notably, the Tisite occupancy is $\sim 2$ cations/ 4 total cations which essentially precludes the incorporation of $\mathrm{Mn}$ on that site. Unlike all of the previous samples discussed, however, the $\mathrm{Ca}$ concentration on the A-site is much less than 1 , equaling $0.72 \mathrm{Ca}$ per 4 total cations. Similarly, the concentrations of $\mathrm{Ce}$ and Gd are lower in these pyrochlores than in the baseline formulation processed under identical conditions; 0.19 vs $0.25 \mathrm{Ce}$ per 4 cations

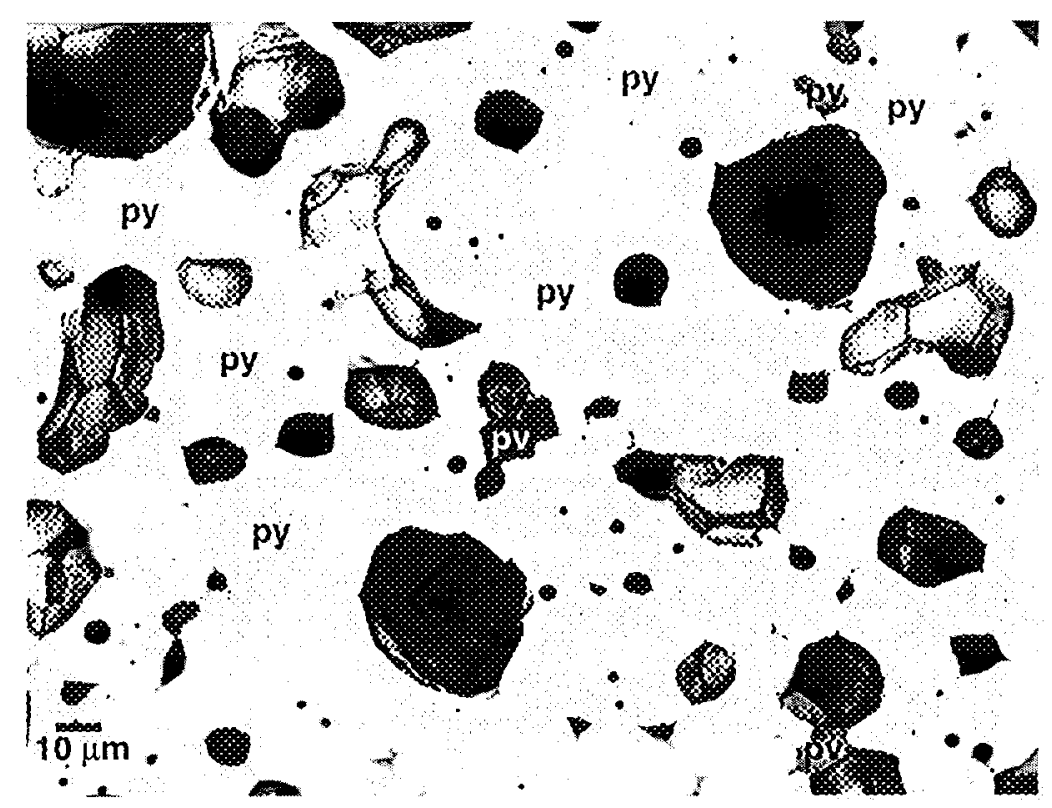

Plate 14. Backscattered electron image of a baseline formulation plus $10 \mathrm{wt} \% \mathrm{MnO}_{2}$, sintered at $1350 \mathrm{C}$ in air (20/1). Assemblage includes pyrochlore (py) and perovskite (pv).

and 0.19 vs $0.23 \mathrm{Gd} / 4$ cations for the $\mathrm{Mn}$-doped and baseline formulations, respectively (Tables 4, 5 and $\mathrm{C} 21$ ). The decreased $\mathrm{Ca}$ and lanthanide concentrations are balanced by the incorporation of manganese. Clearly, the strong affinity of manganese for pyrochlore 
releases $\mathrm{Ca}$ and lanthanides to the matrix that in turn stabilize perovskite. The $\mathrm{Ce} / \mathrm{Gd}$ molar ratio of the Mn-doped pyrochlore is not significantly different from those of the baseline. The uranium content is also similar.

When calculated on the basis of $\mathrm{Ce}^{+4} / \Sigma \mathrm{Ce}=0.33$ and $\mathrm{Mn}^{+2}$, the average uranium valence is greater than $\mathrm{UO}_{3}$. This requires that all uranium be hexavalent or $\mathrm{Ce}^{+4} / \Sigma \mathrm{Ce}$ greater than 0.33 . Alternatively, $\mathrm{Mn}$ could be present in a higher valence state that would allow more typical values of $\mathrm{UO}_{\mathrm{x}}$ and $\mathrm{Ce}^{+4} / \Sigma \mathrm{Ce}$.

The perovskites in the $\mathrm{Mn}$-doped runs are very similar to those observed in the $\mathrm{CaO}$ doped experiments (section 4.1.17 and Table C19 and C20). The T-site is essentially filled by $\mathrm{Ti}$, with small amounts of $\mathrm{Hf}$ and $\mathrm{Al}$, and uranium is barely detectable. The $\mathrm{Ce} / \mathrm{Gd}$ molar ratio is slightly less than one. The only significant difference in the perovskites from the Mn-doped runs is the decreased $\mathrm{Ca}$ content that is compensated by the presence of manganese.

Like the pyrochlores described for other formulations, those in the Mn-doped runs are oxygen deficient for stoichiometries calculated on the basis of $\mathrm{Ce}^{+3}, \mathrm{U}^{+4} \mathrm{Mn}^{+2}$ and no cation vacancies. Unfortunately, given the number of possible combinations of valence states that could be used to reconcile the non-stoichiometry, no unique solution can be obtained based upon the observed chemistry alone. For instance, at $1350^{\circ} \mathrm{C}$ conversion of all the uranium to $\mathrm{U}^{+6}$ and cerium and manganese as +3 and +2 , respectively yields close-to-ideal stoichiometry, $6.90 \mathrm{O} / 4$ cations. Other combinations including $\mathrm{U}^{+4}, \mathrm{U}^{+5}, \mathrm{Ce}^{+4}$ and $\mathrm{Mn}^{+3}$ would yield equivalent results. The uncertainty in valence states propagates into similar uncertainties regarding pyrochlore components and the reactions that describe phase changes due to manganese addition. Possible reactions include the following in which rutile and pyrochlore components are consumed and perovskite and Mn-bearing pyrochlores are produced,

$$
\mathrm{Gd}_{2} \mathrm{Ti}_{2} \mathrm{O}_{7}+2 \mathrm{MnO}+3 \mathrm{TiO}_{2} \Leftrightarrow \mathrm{Mn}_{2} \mathrm{Ti}_{2} \mathrm{O}_{7}+3 \mathrm{Gd}_{2 / 3} \square_{1 / 3} \mathrm{TiO}_{3}+1 / 2 \mathrm{O}_{2}
$$




$$
\mathrm{Ce}_{2} \mathrm{Ti}_{2} \mathrm{O}_{7}+2 \mathrm{MnO}+3 \mathrm{TiO}_{2} \Leftrightarrow \mathrm{Mn}_{2} \mathrm{Ti}_{2} \mathrm{O}_{7}+3 \mathrm{Ce}_{2 / 3} \square_{1 / 3} \mathrm{TiO}_{3}+1 / 2 \mathrm{O}_{2}
$$

where $\square$ represents a vacancy. Reactions 18.1 and 18.2 illustrate the consumption of trivalent lanthanide pyrochlore to produce non-stoichiometric lanthanide perovskite and a trivalent manganese pyrochlore, and involve no change in valence. Oxygen is involved due to the non-stoichiometry of the perovskite components.

$$
\mathrm{CaCe}^{+4} \mathrm{Ti}_{2} \mathrm{O}_{7}+\mathrm{TiO}_{2}+\mathrm{MnO} \Leftrightarrow \mathrm{Mn}^{+2} \mathrm{Ce}^{+4} \mathrm{Ti}_{2} \mathrm{O}_{7}+\mathrm{CaTiO}_{3}
$$

Reaction 18.3 illustrates the consumption of a $\mathrm{Ca}$-quadravalent $\mathrm{Ce}$ pyrochlore to produce and $\mathrm{Mn}$-Ce pyrochlore and a stoichiometric Ca-Ti perovskite molecule. Reactions 18.1, 18.2 and 18.3 are consistent with the reduction in $\mathrm{Ca}$ and lanthanides in pyrochlore and with the stabilization of perovskite resulting from $\mathrm{MnO}$ addition.

Other endmember reactions involve changes in the valence of uranium with addition of manganese. For instance, reaction 18.4 illustrates the consumption of a pentavalent uranium-bearing pyrochlore component, $\left(\mathrm{Ca}_{1.33} \mathrm{U}_{0.66}{ }^{+5}\right) \mathrm{Ti}_{2} \mathrm{O}_{7}$, to produce a quadravalent uranium-bearing pyrochlore and perovskite.

$$
\begin{aligned}
\left(\mathrm{Ca}_{1.33} \mathrm{U}_{0.66}{ }^{+5}\right) \mathrm{Ti}_{2} \mathrm{O}_{7}+0.66 \mathrm{MnO} & +0.66 \mathrm{TiO}_{2} \Leftrightarrow \\
& 0.66\left(\mathrm{MnU}^{+4}\right) \mathrm{Ti}_{2} \mathrm{O}_{7}+1.33 \mathrm{CaTiO}_{3}+0.167 \mathrm{O}_{2} \quad 18.4
\end{aligned}
$$

This reaction also mimics the relatively small change in uranium concentration of pyrochlore with $\mathrm{Mn}$ addition and the decrease in calcium. As in the previous reactions, rutile is consumed and perovskite created. The release of a calcium-rich component in the reactions above, also explains the absence of brannerite in these samples, as calcium reacts with brannerite to form additional pyrochlore. 
Since there is no Mn-rich accessory phase in these assemblages, the impurity limit for manganese will be an issue of desired loading levels as opposed to accessory phase formation.

\subsubsection{The baseline assemblage with $10 \mathrm{wt} \% \mathrm{Gd}_{2} \mathrm{O}_{3}$}

The addition of $10 \mathrm{wt} \% \mathrm{Gd}_{2} \mathrm{O}_{3}$ to the baseline formulation changes the $\mathrm{Ce} / \mathrm{Gd}$ molar ratio of the mixture from $\sim 1$ to $\sim 0.5$, but has no effect on the nature of the baseline phase assemblage (Tables 2 and C22, Plate 15). Experiments at $1300^{\circ} \mathrm{C}$ and $1350^{\circ} \mathrm{C}$ both yield the assemblage pyrochlore - brannerite - rutile. When cast in the lowest potential valence state, the pyrochlore formula from the $1350^{\circ} \mathrm{C}$ run is $\left(\mathrm{Ca}_{0.93} \mathrm{Ce}_{0.19} \mathrm{Gd}_{0.42} \mathrm{Hf}_{0.22} \mathrm{U}_{0.33}\right)\left(\mathrm{Ti}_{1.91} \mathrm{Hf}_{0.22}\right) \mathrm{O}_{6.76}$ which is typically oxygen deficient. This composition yields the ideal $4 / 7$ stoichiometry if $\mathrm{Ce}^{+4} / \Sigma \mathrm{Ce}=0.33$ and the average uranium

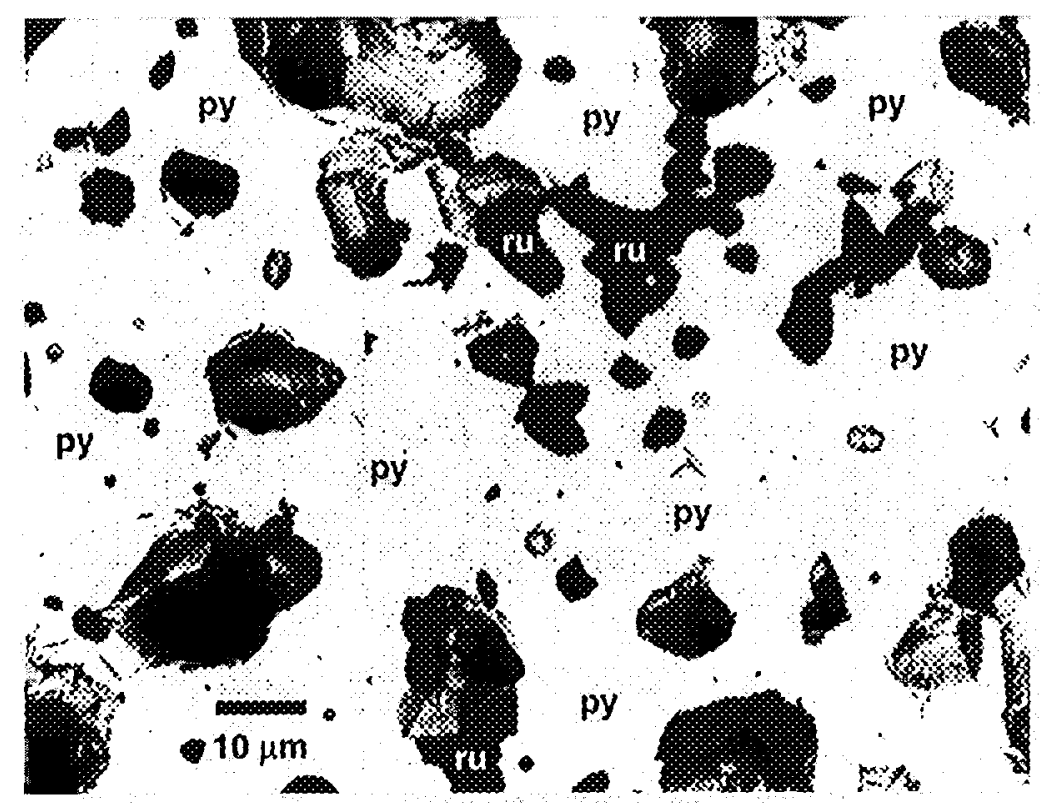

Plate 15 . Baseline formulation with $10 \mathrm{wt} \% \mathrm{Gd}_{2} \mathrm{O}_{3}$ added. Sintered at $1350^{\circ} \mathrm{C}$ in air (14/1). Phase assemblage includes pyrochlore (py) and rutile (ru).

valence is 5.262 (equivalent to $\mathrm{UO}_{\mathrm{x}}$ where $=2.631$ ). The $\mathrm{Ce} / \mathrm{Gd}$ molar ratio in this pyrochlore is 0.46 , and closely tracks the change in the overall bulk composition. As is the case in the baseline formulation without additives, brannerite displays a preference for the 
heavier (smaller radius) lanthanides, and has a $\mathrm{Ce} / \mathrm{Gd}$ molar ratio of 0.67 in the $1350^{\circ} \mathrm{C}$ experiment. The nominal brannerite formula is $\left(\mathrm{Ca}_{0.07} \mathrm{Ce}_{0.17} \mathrm{Gd}_{0.24} \mathrm{Hf}_{0.09} \mathrm{U}_{0.43}\right)\left(\mathrm{Ti}_{1.96} \mathrm{Hf}_{0.02}\right) \mathrm{O}_{5.718}$ which is oxygen deficient, and the ideal $3 / 6$ stoichiometry is obtained if $\mathrm{Ce}^{+4} / \Sigma \mathrm{Ce}=0.33$ and the average uranium valence is $\mathrm{UO}_{2.59}$.

\subsubsection{The baseline assemblage with $10 \mathrm{wt} \% \mathrm{Ga}_{2} \mathrm{O}_{3}$}

The addition of $10 \mathrm{wt} \% \mathrm{Ga}_{2} \mathrm{O}_{3}$ to the baseline formulation stabilizes hafnolite and a calcium-gallium titanate with the nominal formula $\mathrm{CaGa}_{2} \mathrm{Ti}_{3} \mathrm{O}_{10}$ (Tables 2 and $\mathrm{C} 23$, Plate 16). Brannerite and rutile were not observed. The structural formula for pyrochlore is $\left(\mathrm{Ca}_{1.09} \mathrm{Ce}_{0.25} \mathrm{Gd}_{0.21} \mathrm{Hf}_{0.05} \mathrm{U}_{0.42}\right)\left(\mathrm{Ti}_{1.85} \mathrm{Ga}_{0.10} \mathrm{Hf}_{0.05}\right) \mathrm{O}_{6.64}$ and it is typically oxygen deficient when based on the lowest potential oxidation states. This composition yields the ideal $4 / 7$ stoichiometry if $\mathrm{Ce}^{+4} / \Sigma \mathrm{Ce}=0.33$ and the average uranium valence is $\mathrm{UO}_{2.77}$. The $\mathrm{Ce} / \mathrm{Gd}$ molar ratio is $\sim 1.2$, and the $\mathrm{Ga}_{2} \mathrm{O}_{3}$ concentration is $2-2.5 \mathrm{wt} \%$. The pyrochlore in these runs

is similar to that in the additive-free baseline with the exception of an approximately $50 \%$ decrease in the $\mathrm{HfO}_{2}$ concentration presumably due in part to replacement by gallium.

The lower Hf concentration in pyrochlore may also be due to the presence of hafnolite which is relatively enriched in Hf. The structural formula for the hafnolite produced at $1350^{\circ} \mathrm{C}$ is,

$$
\left(\mathrm{Ca}_{0.62} \mathrm{Gd}_{0.24} \mathrm{Ce}_{0.14}\right)\left(\mathrm{Ga}_{0.59} \mathrm{Ce}_{0.05} \mathrm{Hf}_{0.29} \mathrm{U}_{0.13}\right)\left(\mathrm{Ti}_{1.88} \mathrm{Hf}_{0.1}\right) \mathrm{O}_{6.89}
$$

Hafnolite contains less uranium than the coexisting pyrochlore (Table C23) and the ideal 4/7 stoichiometry requires an average uranium valence of $\mathrm{UO}_{2.15}$. Hafnolite is also enriched in gallium relative to pyrochlore containing as much as $\sim 15 \mathrm{wt} \% \mathrm{Ga}_{2} \mathrm{O}_{3}$ at $1300^{\circ} \mathrm{C}$, and displays a strong preference for the heavy lanthanides with a Ce/Gd molar ratio of 0.57 .

The accessory phase, $\mathrm{CaGa}_{2} \mathrm{Ti}_{3} \mathrm{O}_{10}$, contains greater than $30 \mathrm{wt} \% \mathrm{Ga}_{2} \mathrm{O}_{3}$. It also contains $\sim 5 \mathrm{wt} \% \mathrm{Ce}_{2} \mathrm{O}_{3}$ and $\sim 7 \mathrm{wt} \% \mathrm{UO}_{2}$, but only $\sim 5 \mathrm{wt} \% \mathrm{Gd}_{2} \mathrm{O}_{3}$ and $\mathrm{HfO}_{2}$. However, 
given the ability of both pyrochlore and hafnolite to accommodate gallium, we do not expect this phase to form under any realistic compositional or processing scenario. For instance, an assemblage with $80 \mathrm{wt} \%$ pyrochlore and $20 \mathrm{wt} \%$ hafnolite with a $\mathrm{Ga}_{2} \mathrm{O}_{3} / \mathrm{PuO}_{2}$ ratio of 0.43 would yield no Ga-rich accessory phase. We note, however, that in more complex compositions other Ga-rich phases may form at lower Ga concentrations. For instance Stewart et al. (1999) synthesized a baseline formulation containing $\mathrm{Al}, \mathrm{Cr}, \mathrm{Mn}, \mathrm{Fe}$ $\pm \mathrm{V}$ and $\mathrm{Ga}$. When sintered in either $\mathrm{Ar}$ or air at $1350^{\circ} \mathrm{C}$ these materials resulted in the assemblage pyrochlore - hafnolite - perovskite saturated with a Ga-rich accessory titanate phase tentatively identified as loveringite. The concentration of $\mathrm{Ga}$ in the coexisting pyrochlore and hafnolite were roughly $50 \%$ of what we have observed here, consistent with the lower concentration of $\mathrm{Ga}$ in loveringite relative to $\mathrm{CaGa}_{2} \mathrm{Ti}_{3} \mathrm{O}_{10}$.

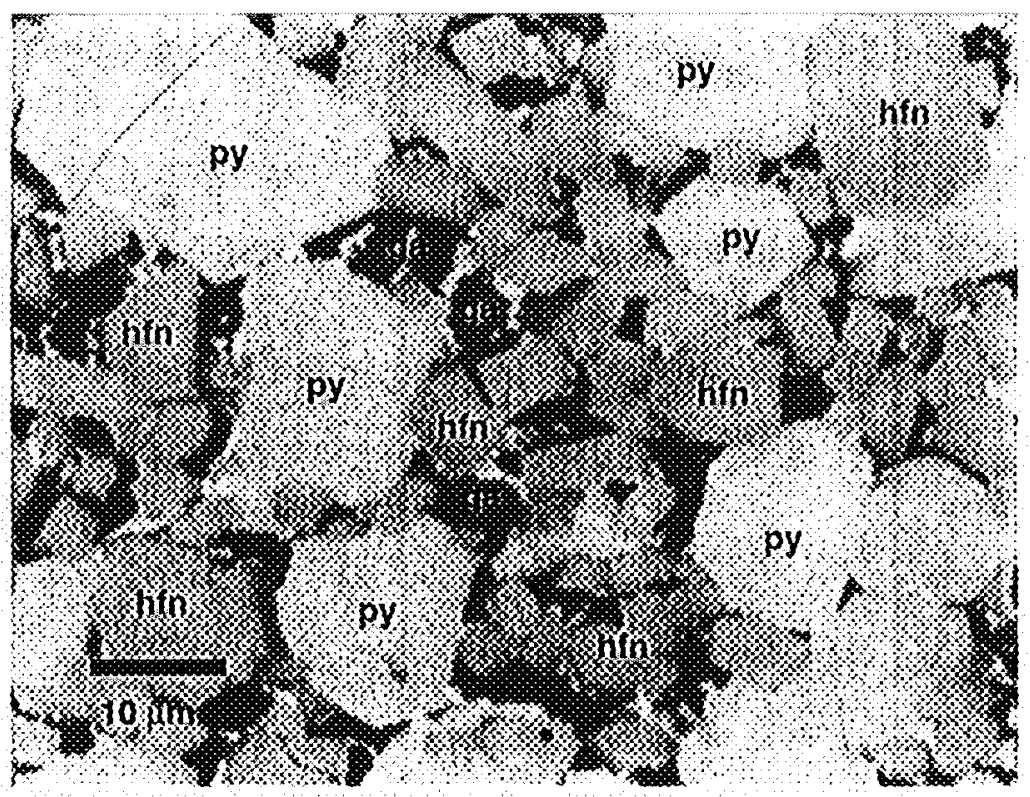

Plate 16. Backscattered electron image of baseline formulation plus $10 \mathrm{wt} \% \mathrm{Ga}_{2} \mathrm{O}_{3}$ sintered at $1350^{\circ} \mathrm{C}$ in air (19/1). Phase assemblage contains pyrochlore (py), hafnolite (hfn) and "galonite" (ga). 


\subsubsection{The baseline assemblage with $10 \mathrm{wt} \% \mathrm{Nb}_{2} \mathrm{O}_{5}$}

The addition of $10 \mathrm{wt} \% \mathrm{Nb}_{2} \mathrm{O}_{5}$ to the baseline formulation yields an assemblage

consisting of pyrochlore - brannerite - rutile - $\mathrm{HfTiO}_{4}$ (Tables 2 and C24). The absence of a niobium-rich accessory phase is explained by the ability of pyrochlore to accommodate $\mathrm{Nb}$ on the T-site. The pyrochlore observed here at $1350^{\circ} \mathrm{C}$ has $\sim 13.5 \mathrm{wt} \% \mathrm{Nb}_{2} \mathrm{O}_{5}$ and the structural formula, $\left(\mathrm{Ca}_{1.11} \mathrm{Ce}_{0.21} \mathrm{Gd}_{0.22} \mathrm{Hf}_{0.1} \mathrm{U}_{0.37}\right)\left(\mathrm{Ti}_{1.43} \mathrm{Hf}_{0.08} \mathrm{Nb}_{0.49}\right) \mathrm{O}_{6.92}$. The molar Ce/Gd ratio is $\sim 1$.

This pyrochlore does not display the pronounced oxygen deficiency observed in most of the other pyrochlores described here. As such, an average uranium valence state of only $\mathrm{UO}_{2.11}$ is required to yield the ideal $4 / 7$ stoichiometry (for $\mathrm{Ce}^{+4} / \Sigma \mathrm{Ce}=0.33$ ). This may be related to the excess charge on the T-site associated with incorporation of pentavalent $\mathrm{Nb}$ that can be charge-balanced by reducing the charge on the A-site (Table C24). In this connection, brannerite has substantially less niobium, and a lower excess charge on the Tsite. The average uranium valence required for $3 / 6$ stoichiometry is $\mathrm{UO}_{2.57}$.

Rutile contains only minor niobium, $\sim 2 \mathrm{wt} \%$. Other than the small amount of niobium accommodated in the hafnium-titanate, $\sim 2 \mathrm{wt} \%$, no other mechanism provides a means to explain the presence of this phase. As such, it may represent unreacted starting materials.

\subsection{Discussion}

The pyrochlore compositions presented here can be used to define a set of endmember components that describe its compositional variability and can be used in formulating additives for the potential wastestream compositions. The coordinate transformation is accomplished by writing a series of mass-balance equations expressing the concentrations of the initial components, in this case normalized cations, in terms of the new components. Inversion of this matix then yields a series of equations expressing the new components in terms of the initial components. Once established, the solubility limits observed for the 
various accessory phases can be expressed in terms of this new component set. This recasting of the solubility limits may help to minimize the effects of coupled substitutions.

The endmember components proposed here (Table 4) were chosen based on the following critieria:

1.) Pyrochlore stoichiometry, $\mathrm{A}_{2} \mathrm{~T}_{2} \mathrm{O}_{7}$ in which the $2 \mathrm{~A}$-sites are equivalent and coupled substitutions involving the $\mathrm{A}$ and $\mathrm{T}$ sites are allowed. This insures that coupled substitutions are realistically simulated.

2.) Multiple oxidation states for cerium and uranium. The compositional trends and results from other work at different oxygen fugacities indicate that both elements are present in more than one oxidation state.

3.) Isolation of each impurity element in a single component. This allows the amount of additive required to accommodate each impurity element in pyrochlore to be easily calculated.

4.) Minimization of negative concentrations for the components chosen. Components that yield negative concentrations when applied to the observed compositions are valid, though of little practical use in determining the amounts of additives required by a particular wastestream composition.

5.) While a particular set of components may yield positive concentrations for some compositions, but result in some negative concentrations for others. We have attempted to maximize the positive concentrations for the components that include the major elements, $\mathrm{Al}, \mathrm{Ca}, \mathrm{Ti}, \mathrm{Ce}, \mathrm{Gd}, \mathrm{Hf}$, and $\mathrm{U}$.

Table 4. Pyrochlore endmember components

$\begin{array}{ll}\mathrm{NaUTi}_{2} \mathrm{O}_{7} & \mathrm{Ca}_{2} \mathrm{Nb}_{2} \mathrm{O}_{7} \\ \mathrm{CaUTiMgO}_{7} & \mathrm{Ca}_{2} \mathrm{TiMoO}_{7} \\ \mathrm{Ti}_{2} \mathrm{Al}_{2} \mathrm{O}_{7} & \mathrm{Ca}_{2} \mathrm{Ta}_{2} \mathrm{O}_{7} \\ \mathrm{Cr}_{2} \mathrm{Ti}_{2} \mathrm{O}_{7} & \mathrm{Ca}_{2} \mathrm{TiWO}_{7} \\ \mathrm{Mn}_{2} \mathrm{Ti}_{2} \mathrm{O}_{7} & \mathrm{Gd}_{2} \mathrm{Ti}_{2} \mathrm{O}_{7} \\ \mathrm{Fe}_{2} \mathrm{Ti}_{2} \mathrm{O}_{7} & \mathrm{Ce}_{2} \mathrm{Ti}_{2} \mathrm{O}_{7} \\ \mathrm{CoTi}_{3} \mathrm{O}_{7} & \mathrm{CaHfTi}_{2} \mathrm{O}_{7} \\ \mathrm{NiTi}_{3} \mathrm{O}_{7} & \mathrm{CaCeTiHfO}_{7} \\ \mathrm{CuTi}_{3} \mathrm{O}_{7} & \mathrm{CaUTi}_{2} \mathrm{O}_{7} \\ \mathrm{ZnTi}_{3} \mathrm{O}_{7} & \mathrm{Ca}_{1.5} \mathrm{U}_{0.5} \mathrm{Ti}_{2} \mathrm{O}_{7} \\ \mathrm{Ti}_{2} \mathrm{Ga}_{2} \mathrm{O}_{7} & \end{array}$


These criteria are actually quite restrictive. For instance, for the baseline composition we have chosen the $\mathrm{Ti}_{2} \mathrm{Al}_{2} \mathrm{O}_{7}, \mathrm{Gd}_{2} \mathrm{Ti}_{2} \mathrm{O}_{7}, \mathrm{Ce}_{2} \mathrm{Ti}_{2} \mathrm{O}_{7}, \mathrm{CaCeTiHfO}_{7}, \mathrm{CaHfTi}_{2} \mathrm{O}_{7}, \mathrm{CaUTi}_{2} \mathrm{O}_{7}$, and $\mathrm{Ca}_{1.5} \mathrm{U}_{0.5} \mathrm{Ti}_{2} \mathrm{O}_{7}$ as components. Here $\mathrm{Ce}_{2} \mathrm{Ti}_{2} \mathrm{O}_{7}$ accommodates $\mathrm{Ce}^{+3}$ and $\mathrm{CaCeTiHfO}_{7}$ accommodates $\mathrm{Ce}^{+4}$. These components restrict the concentration of $\mathrm{Ce}^{+4}$ in pyrochlore to be less than that of $\mathrm{Hf}$ that is also present as $\mathrm{CaHfTi}_{2} \mathrm{O}_{7}$. Similarly, uranium is present as $\mathrm{U}^{+4}$ in $\mathrm{CaUTi}_{2} \mathrm{O}_{7}$ and $\mathrm{U}^{+6}$ in $\mathrm{Ca}_{1.5} \mathrm{U}_{0.5} \mathrm{Ti}_{2} \mathrm{O}_{7}$. A $\mathrm{U}^{+5}$-bearing component is a linear combination of $\mathrm{U}^{+4}$ and $\mathrm{U}^{+6}$-bearing components. When applied to all of the runs containing only the major elements $\mathrm{Al}, \mathrm{Ca}, \mathrm{Ti}, \mathrm{Ce}, \mathrm{Gd}, \mathrm{Hf}$, and $\mathrm{U}$ only 4 negative concentrations out of 144 are obtained (Table 5). The negative concentrations are from the pyrochlores produced from the $\mathrm{CaO}$-doped, $\mathrm{Ca}$-perovskite-saturated experiments that have

Table 5. Pyrochlore component mole fractions for baseline compositions without

\begin{tabular}{|c|c|c|c|c|c|c|c|}
\hline & $\mathrm{Ti}_{2} \mathrm{Al}_{2} \mathrm{O}$ & $\mathrm{Gd}_{2} \mathrm{Ti}_{2} \mathrm{O}_{3}$ & $\mathrm{Ce}_{2} \mathrm{Ti}_{2} \mathrm{O}_{3}$ & $\mathrm{CaCeTiHfO}_{7}$ & $\mathrm{CaHfTi}_{2} \mathrm{O}_{7}$ & $\mathrm{CaUTi}_{2} \mathrm{O}_{7}$ & $\mathrm{Ca}_{1.5} \mathrm{U}_{0.5} \mathrm{Ti}_{2} \mathrm{O}_{7}$ \\
\hline $1 / 1$ & 0.004 & 0.112 & 0.056 & 0.125 & 0.070 & 0.135 & 0.498 \\
\hline $1 / 2$ & 0.000 & 0.116 & 0.059 & 0.127 & 0.101 & 0.180 & 0.417 \\
\hline $1 / 3$ & 0.008 & 0.116 & 0.087 & 0.072 & 0.149 & 0.120 & 0.448 \\
\hline $5 / 1$ & 0.002 & 0.117 & 0.057 & 0.120 & 0.065 & 0.182 & 0.456 \\
\hline $5 / 2$ & 0.003 & 0.115 & 0.061 & 0.106 & 0.119 & 0.172 & 0.423 \\
\hline $5 / 3$ & 0.006 & 0.116 & 0.050 & 0.129 & 0.094 & 0.168 & 0.436 \\
\hline $7 / 1$ & 0.013 & 0.109 & 0.084 & 0.098 & 0.033 & 0.099 & 0.561 \\
\hline $7 / 2$ & 0.015 & 0.132 & 0.039 & 0.145 & 0.043 & 0.142 & 0.479 \\
\hline $7 / 3$ & 0.014 & 0.106 & 0.092 & 0.081 & 0.068 & 0.104 & 0.533 \\
\hline $3 / 1$ & 0.003 & 0.087 & 0.012 & 0.174 & 0.045 & 0.086 & 0.593 \\
\hline $3 / 2$ & 0.005 & 0.089 & 0.006 & 0.173 & 0.094 & 0.108 & 0.525 \\
\hline $3 / 3$ & 0.006 & 0.086 & 0.009 & 0.171 & 0.091 & 0.103 & 0.533 \\
\hline $9 / 1$ & 0.001 & 0.096 & -0.105 & 0.420 & -0.034 & 0.225 & 0.396 \\
\hline $9 / 2$ & 0.000 & 0.055 & -0.069 & 0.345 & -0.053 & 0.214 & 0.487 \\
\hline $13 / 1$ & 0.013 & 0.092 & 0.087 & 0.048 & 0.093 & 0.025 & 0.639 \\
\hline $13 / 2$ & 0.008 & 0.093 & 0.085 & 0.060 & 0.057 & 0.042 & 0.654 \\
\hline $14 / 1$ & 0.003 & 0.211 & 0.050 & 0.090 & 0.126 & 0.130 & 0.389 \\
\hline $14 / 2$ & 0.003 & 0.210 & 0.036 & 0.122 & 0.093 & 0.123 & 0.413 \\
\hline Avg. & 0.007 & 0.115 & 0.065 & 0.111 & 0.083 & 0.145 & 0.472 \\
\hline Dev. & 0.006 & 0.007 & 0.018 & 0.024 & 0.037 & 0.032 & 0.050 \\
\hline
\end{tabular}

the highest $\mathrm{Ca}$ concentrations, suggesting that another set of components might be a more appropriate choice for such compositions. Aluminum is cast at $\mathrm{Ti}_{2} \mathrm{Al}_{2} \mathrm{O}_{7}$ in which $\mathrm{Ti}$ resides on the A-site and $\mathrm{Al}$ on the T-site. Structurally, this is probably not the best choice 
of components for $\mathrm{Al}$ as $\mathrm{Ti}$ has a small ionic radius compared with other cations found on the A-site. Nevertheless, we feel that is a conservative choice that would tend to result in excess $\mathrm{TiO}_{2}$ that is easily accommodated in rutile. $\mathrm{Ce}_{2} \mathrm{Al}_{2} \mathrm{O}_{7}$ is another possible choice for an Al-rich component, but yields almost identical results due to the low concentrations of $\mathrm{Al}$ in pyrochlore.

We note that our initial choice of components included $\mathrm{Ce}_{2} \mathrm{Ti}_{2} \mathrm{O}_{7}, \mathrm{CaCeTi}_{2} \mathrm{O}_{7}$, $\mathrm{CaUTi}_{2} \mathrm{O}_{7}, \mathrm{Ca}_{1.5} \mathrm{U}_{0.5} \mathrm{Ti}_{2} \mathrm{O}_{7}$ which appeared to be less restrictive in terms of fixing the oxidation states of cerium and uranium. Unfortunately, this set of components is not linearly independent and are related by the following equation,

$$
\mathrm{CaCeTi}_{2} \mathrm{O}_{7}+1 / 2 \mathrm{CaUTi}_{2} \mathrm{O}_{7}=\mathrm{Ca}_{1.5} \mathrm{U}_{0.5} \mathrm{Ti}_{2} \mathrm{O}_{7}+1 / 2 \mathrm{Ce}_{2} \mathrm{Ti}_{2} \mathrm{O}_{7}
$$

The divalent transition metals, $\mathrm{M}$, have been cast as $\mathrm{MTi}_{3} \mathrm{O}_{7}$ and include $\mathrm{CoTi}_{3} \mathrm{O}_{7}$, $\mathrm{NiTi}_{3} \mathrm{O}_{7}, \mathrm{ZnTi}_{3} \mathrm{O}_{7}$, etc. This requires $\mathrm{Ti}$ on the A-site, but again represents a conservative choice as it would result in excess $\mathrm{TiO}_{2}$. Iron, chromium and manganese are all considered to be trivalent under proposed processing conditions and are cast as $\mathrm{Fe}_{2} \mathrm{Ti}_{2} \mathrm{O}_{7}, \mathrm{Cr}_{2} \mathrm{Ti}_{2} \mathrm{O}_{7}$ and $\mathrm{Mn}_{2} \mathrm{Ti}_{2} \mathrm{O}_{7}$. Our analysis of the compositions of pyrochlores in Mg-doped runs suggests that $\mathrm{Mg}$ resides on the $\mathrm{T}$-site. The $\mathrm{Mg}$-component used is $\mathrm{CaUTiMgO}_{7}$ in which $\mathrm{Mg}$ is charged balanced by $\mathrm{U}^{+6}$. Gallium is treated like aluminum and yields $\mathrm{Ti}_{2} \mathrm{Ga}_{2} \mathrm{O}_{7}$. The highfield strength elements $\mathrm{Nb}, \mathrm{Ta}, \mathrm{Mo}$ and $\mathrm{W}$ reside on the T-site and are charge balanced by replacing tri- with divalent cations on the A-site, $\mathrm{Ca}_{2} \mathrm{Nb}_{5} \mathrm{O}_{7}, \mathrm{Ca}_{2} \mathrm{Ta}_{5} \mathrm{O}_{7}, \mathrm{Ca}_{2} \mathrm{TiMoO}_{7}$, $\mathrm{Ca}_{2} \mathrm{TiWO}_{7}$. Sodium is cast as $\mathrm{NaUTi}_{2} \mathrm{O}_{7}$ in which $\mathrm{U}^{+5}$ and $\mathrm{Na}^{+}$substitute on the A-site. This is based upon our measurements of Na-bearing, but $\mathrm{Nb} / \mathrm{Ta}$-free compositions. Coupled substitution involving $\mathrm{Na}$ and $\mathrm{Nb} / \mathrm{Ta}$ for $\mathrm{Ca}$ and $\mathrm{Ti}$ have been demonstrated elsewhere, and could be used as alternate components for $\mathrm{Na}$. It is our expectation that $\mathrm{Na}$ will typically be more abundant on a molar basis than $\mathrm{Nb}+\mathrm{Ta}$, and components like $\mathrm{NaCe}^{+4} \mathrm{TiNbO}_{7}$ would commonly result in negative concentrations. Conversely, uranium 
will always be more abundant than sodium resulting in positive concentrations for $\mathrm{NaUTi}_{2} \mathrm{O}_{7}$.

The concentrations of endmember components for impurity-free runs ( $\mathrm{Al}, \mathrm{Ca}, \mathrm{Ti}, \mathrm{Ce}, \mathrm{Gd}$, Hf, and U only) are given in Table 5, and yield a well-defined average for the perovskitefree samples. The major component is $\mathrm{Ca}_{1.5} \mathrm{U}_{0.5} \mathrm{Ti}_{2} \mathrm{O}_{7}$ with a mole fraction of $0.47 \pm 0.05$, followed by roughly equal amounts of $\mathrm{Gd}_{2} \mathrm{Ti}_{2} \mathrm{O} 7, \mathrm{CaCeTiHfO}_{7}, \mathrm{CaUTi}_{2} \mathrm{O}_{7}$ with mole fractions of $0.11-0.15 . \mathrm{Ce}_{2} \mathrm{Ti}_{2} \mathrm{O}_{7}$ and $\mathrm{CaHfTi}_{2} \mathrm{O}_{7}$ have mole fractions of 0.065 and 0.083 , respectively, and $\mathrm{Ti}_{2} \mathrm{Al}_{2} \mathrm{O}_{7}$ is negligible. This corresponds to an average baseline pyrochlore composition of $\mathrm{Ca}_{1.05} \mathrm{Ce}_{0.24} \mathrm{Gd}_{0.23} \mathrm{U}_{0.39} \mathrm{Hf}_{0.09} \mathrm{Ti}_{1.89} \mathrm{Al}_{0.01} \mathrm{Hf}_{0.10} \mathrm{O}_{7}$. The variations in pyrochlore component compositions produced by impurity additions (Table 6) are easily reconciled in terms of pyrochlore crystal-chemistry.

Sodium is associated with hexavalent uranium in the molecule $\mathrm{NaUTi}_{2} \mathrm{O}_{7}$. The major effect of sodium addition is to consume the quadravelent uranium-bearing component, $\mathrm{CaUTi}_{2} \mathrm{O}_{7}$. This is equivalent to oxidation of uranium that was discussed earlier.

The addition of calcium (as either oxide or fluoride) is reflected as an increase in $\mathrm{CaCeTiHfO}_{7}$ and decreases in $\mathrm{Ce}_{2} \mathrm{Ti}_{2} \mathrm{O}_{7}$ and $\mathrm{CaHfTi}_{2} \mathrm{O}_{7}$ that in some cases yield small negative concentrations. By fixing cerium and hafnium in $\mathrm{CaCeTiHfO}_{7}$ the remaining components are relatively depleted, corresponding to a decrease in the concentrations of $\mathrm{Ce}_{2} \mathrm{Ti}_{2} \mathrm{O}_{7}$ and $\mathrm{CaHfTi}_{2} \mathrm{O}_{7}$. We have tried a number of other possible component sets in combination with assumptions regarding the valence states of cerium and uranium, and find no improvement over the components presented here for high-Ca pyrochlores.

The addition of $\mathrm{Mg}$ yields $\mathrm{CaUTiMgO}_{7}$ with corresponding decreases in the other uranium-bearing components, $\mathrm{CaUTi}_{2} \mathrm{O}_{7}$ and $\mathrm{Ca}_{1.5} \mathrm{U}_{0.5} \mathrm{Ti}_{2} \mathrm{O}_{7}$. The fixation of $\mathrm{Ca}$ in $\mathrm{CaUTiMgO}_{7}$ may also lead to small negative concentrations of $\mathrm{Ce}_{2} \mathrm{Ti}_{2} \mathrm{O}_{7}$ and $\mathrm{CaHfTi}_{2} \mathrm{O}_{7}$ for reasons outlined for high-Ca samples above. 
Table 6. Pyrochlore mole fractions of impurity runs on $\mathrm{Ce}-\mathrm{Hf}-\mathrm{U}$ formulation with and without added impurities

\begin{tabular}{|c|c|c|c|c|c|c|c|c|c|c|c|c|c|c|c|c|c|c|c|c|c|}
\hline & $\mathrm{NaUTi}_{2} \mathrm{O}_{1}$ & CaUTiMgO, & $\mathrm{Ti}_{1} \mathrm{Al}_{2} \mathrm{O} 7$ & $\mathrm{Cr}_{2} \mathrm{~T}_{i_{2}} \mathrm{O}_{7}$ & $\mathrm{Mn}_{1} \mathrm{~T}_{2} \mathrm{O}_{1}$ & $\mathrm{Fe}_{2} \mathrm{Ti}_{2} \mathrm{O}_{7}$ & $\mathrm{CoTi}_{1} \mathrm{O}$ & $\mathrm{NiTi}, \mathrm{O}_{7}$ & $\mathrm{CuTi}, \mathrm{O}$ & $\mathrm{ZnTi}_{3}, \mathrm{O}$ & $\mathrm{Ti}_{2} \mathrm{Ga}_{2} \mathrm{O}$, & $\mathrm{Ca}_{2} \mathrm{Nb}_{2} \mathrm{O}_{7}$ & $\mathrm{Ca}_{2} \mathrm{TiMOO}_{1}$ & $\mathrm{Ca}_{2} \mathrm{Ta}_{2} \mathrm{O}_{7}$ & $\mathrm{Ca}_{3} \mathrm{TiWO}_{1}$ & $\mathrm{Gd}_{2} \mathrm{Ti}_{2} \mathrm{O}_{7}$ & $\mathrm{Ce}_{2} \mathrm{~T}_{2} \mathrm{O}$ & $\mathrm{CaHfT}_{2} \mathrm{O}$, & $\mathrm{CaCeTiHfO}_{7}$ & $\mathrm{CaUTi}_{2} \mathrm{O}, \mathrm{C}_{1}$ & $\overline{\mathrm{I}_{6} \mathrm{~T}_{2} \mathrm{O}_{7}}$ \\
\hline $1 / 1$ & 0.000 & 0.000 & 0.004 & 0.000 & 0.000 & 0.000 & 0.000 & -0.000 & 0.000 & -0.000 & 0.000 & 0.000 & 0.000 & 0.000 & 0.000 & 0.112 & 0.055 & 0.068 & 0.127 & 0.140 & 0.494 \\
\hline $1 / 2$ & 0.000 & 0.000 & 0.000 & 0.000 & 0.000 & 0.000 & 0.000 & -0.000 & 0.000 & -0.000 & 0.000 & 0.000 & 0.000 & 0.000 & 0.000 & 0.116 & 0.059 & 0.101 & 0.127 & 0.180 & 0.417 \\
\hline $1 \beta$ & 0.000 & 0.000 & 0.008 & 0.000 & 0.000 & 0.000 & 0.000 & -0.000 & 0.000 & -0.000 & 0.000 & 0.000 & 0.000 & 0.000 & 0.000 & 0.116 & 0.085 & 0.146 & 0.075 & 0.131 & 0.440 \\
\hline $5 / 1$ & 0.000 & 0.000 & 0.002 & 0.000 & 0.000 & 0.000 & 0.000 & -0.000 & 0.000 & -0.000 & 0.000 & 0.000 & 0.000 & 0.000 & 0.000 & 0.117 & 0.057 & 0.064 & 0.121 & 0.185 & 0.454 \\
\hline $5 / 2$ & 0.000 & 0.000 & 0.003 & 0.000 & 0.000 & 0.000 & 0.000 & -0.000 & 0.000 & -0.000 & 0.000 & 0.000 & 0.000 & 0.000 & 0.000 & 0.115 & 0.060 & 0.118 & 0.108 & 0.176 & 0.420 \\
\hline $5 / 3$ & 0.000 & 0.000 & 0.006 & 0.000 & 0.000 & 0.000 & 0.000 & -0.000 & 0.000 & -0.000 & 0.000 & 0.000 & 0.000 & 0.000 & 0.000 & 0.116 & 0.048 & 0.091 & 0.132 & 0.177 & 0.430 \\
\hline $7 / 1$ & 0.000 & 0.000 & 0.013 & 0.000 & 0.000 & 0.000 & 0.000 & -0.000 & 0.000 & -0.000 & 0.000 & 0.000 & 0.000 & 0.000 & 0.000 & 0.109 & 0.081 & 0.027 & 0.104 & 0.119 & 0.548 \\
\hline 72 & 0.000 & 0.000 & 0.015 & 0.000 & 0.000 & 0.000 & 0.000 & -0.000 & 0.000 & -0.000 & 0.000 & 0.000 & 0.000 & 0.000 & 0.000 & 0.132 & 0.036 & 0.036 & 0.153 & 0.164 & 0.464 \\
\hline 73 & 0.000 & 0.000 & 0.014 & 0.000 & 0.000 & 0.000 & 0.000 & -0.000 & 0.000 & -0.000 & 0.000 & 0.000 & 0.000 & 0.000 & 0.000 & 0.106 & 0.089 & 0.061 & 0.088 & 0.125 & 0.519 \\
\hline $3 / 1$ & 0.000 & 0.000 & 0.003 & 0.000 & 0.000 & 0.000 & 0.000 & -0.000 & 0.000 & -0.000 & 0.000 & 0.000 & 0.000 & 0.000 & 0.000 & 0.087 & 0.011 & 0.044 & 0.175 & 0.090 & 0.591 \\
\hline $3 / 2$ & 0.000 & 0.000 & 0.005 & 0.000 & 0.000 & 0.000 & 0.000 & -0.000 & 0.000 & -0.000 & 0.000 & 0.000 & 0.000 & 0.000 & 0.000 & 0.089 & 0.004 & 0.091 & 0.175 & 0.114 & 0.521 \\
\hline $3 / 3$ & 0.000 & 0.000 & 0.006 & 0.000 & 0.000 & 0.000 & 0.000 & -0.000 & 0.000 & -0.000 & 0.000 & 0.000 & 0.000 & 0.000 & 0.000 & 0.086 & 0.007 & 0.088 & 0.174 & 0.111 & 0.528 \\
\hline $9 / 1$ & 0.000 & 0.000 & 0.001 & 0.000 & 0.000 & 0.000 & 0.000 & -0.000 & 0.000 & -0.000 & 0.000 & 0.000 & 0.000 & 0.000 & 0.000 & 0.096 & -0.105 & -0.035 & 0.420 & 0.228 & 0.395 \\
\hline $9 / 2$ & 0.000 & 0.000 & 0.000 & 0.000 & 0.000 & 0.000 & 0.000 & -0.000 & 0.000 & -0.000 & 0.000 & 0.000 & 0.000 & 0.000 & 0.000 & 0.055 & -0.069 & -0.053 & 0.345 & 0.214 & 0.487 \\
\hline $13 / 1$ & 0.000 & 0.000 & 0.013 & 0.000 & 0.000 & 0.000 & 0.000 & -0.000 & 0.000 & -0.000 & 0.000 & 0.000 & 0.000 & 0.000 & 0.000 & 0.092 & 0.083 & 0.087 & 0.055 & 0.044 & 0.626 \\
\hline $13 / 2$ & 0.000 & 0.000 & 0.008 & 0.000 & 0.000 & 0.000 & 0.000 & -0.000 & 0.000 & -0.000 & 0.000 & 0.000 & 0.000 & 0.000 & 0.000 & 0.093 & 0.083 & 0.052 & 0.064 & 0.055 & 0.645 \\
\hline $14 / 1$ & 0.000 & 0.000 & 0.003 & 0.000 & 0.000 & 0.000 & 0.000 & -0.000 & 0.000 & -0.000 & 0.000 & 0.000 & 0.000 & 0.000 & 0.000 & 0.211 & 0.049 & 0.124 & 0.092 & 0.135 & 0.386 \\
\hline 1422 & 0.000 & 0.000 & 0.003 & 0.000 & 0.000 & 0.000 & 0.000 & -0.000 & 0.000 & -0.000 & 0.000 & 0.000 & 0.000 & 0.000 & 0.000 & 0.210 & 0.036 & 0.092 & 0.123 & 0.127 & 0.410 \\
\hline $6 / 1$ & 0.000 & 0.153 & 0.001 & 0.000 & 0.000 & 0.000 & 0.000 & -0.000 & 0.000 & -0.000 & 0.000 & 0.000 & 0.000 & 0.000 & 0.000 & 0.122 & -0.037 & -0.056 & 0.346 & 0.164 & 0.307 \\
\hline 62 & 0.000 & 0.218 & 0.000 & 0.000 & 0.000 & 0.000 & 0.000 & -0.000 & 0.000 & -0.000 & 0.000 & 0.000 & 0.000 & 0.000 & 0.000 & 0.118 & 0.028 & 0.072 & 0.197 & 0.106 & 0.260 \\
\hline $6 / 3$ & 0.000 & 0.215 & 0.001 & 0.000 & 0.000 & 0.000 & 0.000 & -0.000 & 0.000 & -0.000 & 0.000 & 0.000 & 0.000 & 0.000 & 0.000 & 0.118 & -0.005 & 0.032 & 0.270 & 0.122 & 0.246 \\
\hline $12 / 1$ & 0.000 & 0.091 & 0.013 & 0.000 & 0.000 & 0.000 & 0.000 & -0.000 & 0.000 & -0.000 & 0.000 & 0.000 & 0.000 & 0.000 & 0.000 & 0.110 & 0.122 & 0.150 & 0.009 & 0.051 & 0.454 \\
\hline 122 & 0.000 & 0.081 & 0.010 & 0.000 & 0.000 & 0.000 & 0.000 & -0.000 & 0.000 & -0.000 & 0.000 & 0.000 & 0.000 & 0.000 & 0.000 & 0.105 & 0.115 & 0.111 & 0.021 & 0.062 & 0.495 \\
\hline $17 / 1$ & 0.000 & 0.000 & 0.002 & 0.000 & 0.000 & 0.000 & 0.000 & 0.127 & 0.000 & -0.000 & 0.000 & 0.000 & 0.000 & 0.000 & 0.000 & 0.114 & -0.049 & -0.125 & 0.342 & 0.185 & 0.401 \\
\hline 1772 & 0.000 & 0.000 & 0.000 & 0.000 & 0.000 & 0.000 & 0.000 & 0.111 & 0.000 & -0.000 & 0.000 & 0.000 & 0.000 & 0.000 & 0.000 & 0.112 & -0.009 & -0.092 & 0.274 & 0.135 & 0.469 \\
\hline $18 / 1$ & 0.000 & 0.000 & 0.003 & 0.055 & 0.000 & 0.000 & 0.000 & -0.000 & 0.000 & -0.000 & 0.000 & 0.000 & 0.000 & 0.000 & 0.000 & 0.128 & 0.007 & -0.060 & 0.249 & 0.182 & 0.436 \\
\hline 182 & 0.000 & 0.000 & 0.004 & 0.054 & 0.000 & 0.000 & 0.000 & -0.000 & 0.000 & -0.000 & 0.000 & 0.000 & 0.000 & 0.000 & 0.000 & 0.130 & 0.028 & -0.015 & 0.213 & 0.055 & 0.512 \\
\hline $19 / 1$ & 0.000 & 0.000 & 0.000 & 0.000 & 0.000 & 0.000 & 0.000 & -0.000 & 0.000 & -0.000 & 0.049 & 0.000 & 0.000 & 0.000 & 0.000 & 0.104 & 0.047 & -0.058 & 0.154 & 0.128 & 0.575 \\
\hline 192 & 0.000 & 0.000 & 0.002 & 0.000 & 0.000 & 0.000 & 0.000 & -0.000 & 0.000 & -0.000 & 0.053 & 0.000 & 0.000 & 0.000 & 0.000 & 0.080 & 0.057 & -0.093 & 0.155 & 0.094 & 0.652 \\
\hline 2011 & 0.000 & 0.000 & 0.005 & 0.000 & 0.230 & 0.000 & 0.000 & -0.000 & 0.000 & -0.000 & 0.000 & 0.000 & 0.000 & 0.000 & 0.000 & 0.095 & 0.028 & 0.092 & 0.132 & 0.256 & 0.162 \\
\hline 2012 & 0.000 & 0.000 & 0.007 & 0.000 & 0.233 & 0.000 & 0.000 & -0.000 & 0.000 & -0.000 & 0.000 & 0.000 & 0.000 & 0.000 & 0.000 & 0.092 & 0.029 & 0.081 & 0.137 & 0.234 & 0.188 \\
\hline $21 / 1$ & 0.000 & 0.000 & 0.003 & 0.000 & 0.000 & 0.000 & 0.000 & -0.000 & 0.091 & -0.000 & 0.000 & 0.000 & 0.000 & 0.000 & 0.000 & 0.122 & -0.002 & 0.022 & 0.230 & 0.191 & 0.345 \\
\hline $21 / 2$ & 0.000 & 0.000 & 0.002 & 0.000 & 0.000 & 0.000 & 0.000 & -0.000 & 0.063 & -0.000 & 0.000 & 0.000 & 0.000 & 0.000 & 0.000 & 0.123 & 0.008 & -0.018 & 0.225 & 0.187 & 0.408 \\
\hline $22 / 1$ & 0.000 & 0.000 & 0.004 & 0.000 & 0.000 & 0.000 & 0.000 & -0.000 & 0.000 & 0.018 & 0.000 & 0.000 & 0.000 & 0.000 & 0.000 & 0.123 & 0.056 & 0.134 & 0.121 & 0.181 & 0.362 \\
\hline 2221 & 0.000 & 0.000 & 0.000 & 0.000 & 0.000 & 0.000 & 0.000 & -0.000 & 0.000 & 0.116 & 0.000 & 0.000 & 0.000 & 0.000 & 0.000 & 0.089 & 0.032 & -0.071 & 0.166 & 0.083 & 0.585 \\
\hline P229 & 0.000 & 0.000 & 0.000 & 0.000 & 0.000 & 0.000 & 0.000 & -0.000 & 0.000 & -0.000 & 0.000 & 0.000 & 0.057 & 0.000 & 0.000 & 0.128 & 0.040 & 0.115 & 0.132 & 0.184 & 0.345 \\
\hline P232 & 0.000 & 0.000 & 0.000 & 0.000 & 0.000 & 0.000 & 0.000 & -0.000 & 0.000 & -0.000 & 0.000 & 0.000 & 0.000 & 0.000 & 0.309 & 0.111 & 0.086 & 0.153 & 0.015 & 0.384 & -0.058 \\
\hline $\mathrm{P} 243$ & 0.000 & 0.000 & 0.000 & 0.000 & 0.000 & 0.000 & 0.000 & -0.000 & 0.000 & -0.000 & 0.000 & 0.087 & 0.000 & 0.000 & 0.000 & 0.105 & 0.049 & -0.175 & 0.392 & 0.195 & 0.348 \\
\hline $15 / 1$ & 0.141 & 0.000 & 0.006 & 0.000 & 0.000 & 0.000 & 0.000 & -0.000 & 0.000 & -0.000 & 0.000 & 0.000 & 0.000 & 0.000 & 0.000 & 0.122 & 0.058 & 0.085 & 0.131 & 0.022 & 0.433 \\
\hline $15 / 2$ & 0.148 & 0.000 & 0.005 & 0.000 & 0.000 & 0.000 & 0.000 & -0.000 & 0.000 & -0.000 & 0.000 & 0.000 & 0.000 & 0.000 & 0.000 & 0.110 & 0.070 & 0.045 & 0.121 & 0.012 & 0.490 \\
\hline 161 & 0.163 & 0.000 & 0.005 & 0.000 & 0.000 & 0.000 & 0.000 & -0.000 & 0.000 & -0.000 & 0.000 & 0.000 & 0.000 & 0.000 & 0.000 & 0.136 & 0.042 & 0.066 & 0.185 & 0.001 & 0.400 \\
\hline 162 & 0.179 & 0.000 & 0.004 & 0.000 & 0.000 & 0.000 & 0.000 & -0.000 & 0.000 & -0.000 & 0.000 & 0.000 & 0.000 & 0.000 & 0.000 & 0.115 & 0.087 & 0.067 & 0.098 & -0.048 & 0.496 \\
\hline
\end{tabular}


Magnesium is the only divalent cation we believe to be incorportated on the T-site. The effect of adding other divalent cations is best illustrated by the Ni-bearing runs. Here nickel is incorporated as $\mathrm{NiTi}_{3} \mathrm{O}_{7}$, which requires $3 \mathrm{Ti} / \mathrm{Ni}$ atoms. The relatively high Ti content of this component depletes the amount of $\mathrm{Ti}$ available to the other components, and is reflected in negative concentrations for the remaining components with the highest Ti/M ratios, $\mathrm{Ce}_{2} \mathrm{Ti}_{2} \mathrm{O}_{7}$ and $\mathrm{CaHfTi}_{2} \mathrm{O}_{7} \cdot \mathrm{Gd}_{2} \mathrm{Ti}_{2} \mathrm{O}_{7}$ is unaffected as it is the only Gd-bearing molecule formulated. Minor improvement, i.e., smaller negative concentrations, can be obtained by casting $\mathrm{Ni}$ as $\mathrm{NiCeTi}_{2} \mathrm{O}_{7}, \mathrm{NiHfTi}_{2} \mathrm{O}_{7}$ or $\mathrm{NiUTi}_{2} \mathrm{O}_{7}$ where the ratio of $\mathrm{Ti}$ to $\mathrm{Ni}$ is lower. However, if these components are to be used in formulating additives, $\mathrm{NiTi}_{3} \mathrm{O}_{7}$ is the preferred component as it will result in an excess of Ti that is buffered by rutile. The other divalent cations will yield similar results.

Similar patterns are also produced by the addition of trivalent cations such as $\mathrm{Cr}, \mathrm{Fe}$, $\mathrm{Mn}$ and $\mathrm{Ga}$ where $\mathrm{M}_{2} \mathrm{Ti}_{2} \mathrm{O}_{7}$ components fix Ti and can yield concentrations for $\mathrm{Ce}_{2} \mathrm{Ti}_{2} \mathrm{O}_{7}$ and $\mathrm{CaHfTi}_{2} \mathrm{O}_{7}$. Molecules based on more complicated substitutions, including substitution of trivalent cations on the T-site help to reduce the concentrations of negative components but are not as conservative with respect to the production of excess $\mathrm{TiO}_{2}$. For instance, casting $\mathrm{Fe}$ as $\mathrm{FeCe}^{+4}(\mathrm{FeTi}) \mathrm{O}_{7}$ virtually eliminates negative concentrations for the Fe-bearing runs presented here.

The high-field strength cations $\mathrm{Mo}, \mathrm{W}$ and $\mathrm{Nb}$ all tie up $\mathrm{Ca}$ and to a lesser extent $\mathrm{Ti}$. Since divalent cations are required to charge balance $\mathrm{U}^{+6}$ on the A-site, incorporation of these elements should convert $\mathrm{Ca}_{1.5} \mathrm{U}_{0.5} \mathrm{Ti}_{2} \mathrm{O}_{7}$ to $\mathrm{CaUTi}_{2} \mathrm{O}_{7}$. This is best illustrated by comparing the component concentrations for Mo- and W-bearing runs (Table 6). Tungsten is more compatible than molybdenum in pyrochlore and $\mathrm{Ca}_{1.5} \mathrm{U}_{0.5} \mathrm{Ti}_{2} \mathrm{O}_{7}$ is completely consumed in the W-bearing materials. $\mathrm{CaCeTiHfO}_{7}$ is also decreased in the $\mathrm{W}$ bearing samples as it is the only Ca-bearing component not specifically tied to a single quadravlent cation other than Ti. $\mathrm{Ca}_{2} \mathrm{Nb}_{2} \mathrm{O}_{7}$ ties up $\mathrm{Ca}$, but no Ti; addition of niobium 
consumes $\mathrm{CaHfTi}_{2} \mathrm{O}_{7}$ and increases the concentration of $\mathrm{CaCeTiHfO}_{7}$. Another possible substitution for niobium could be as a replacement for $\mathrm{Ti}$ in $\mathrm{Ca}_{15} \mathrm{U}_{0.5} \mathrm{Ti}_{2} \mathrm{O}_{7}$, $\mathrm{Ca}_{1.5} \mathrm{U}_{0.5} \mathrm{TiNbO}_{7}$. in which $\mathrm{U}^{+6}$ is reduced to $\mathrm{U}^{+4}$. The consumption of $\mathrm{U}^{+4}$ species is also apparent when we apply these components (Table 4) to the impurity-bearing samples made by ANSTO (Vance et al., 1999) (Table 7) in which $\mathrm{Nb} /$ Ta-bearing materials have negative concentrations for $\mathrm{Ca}_{1.5} \mathrm{U}_{0.5} \mathrm{Ti}_{2} \mathrm{O}_{7}$.

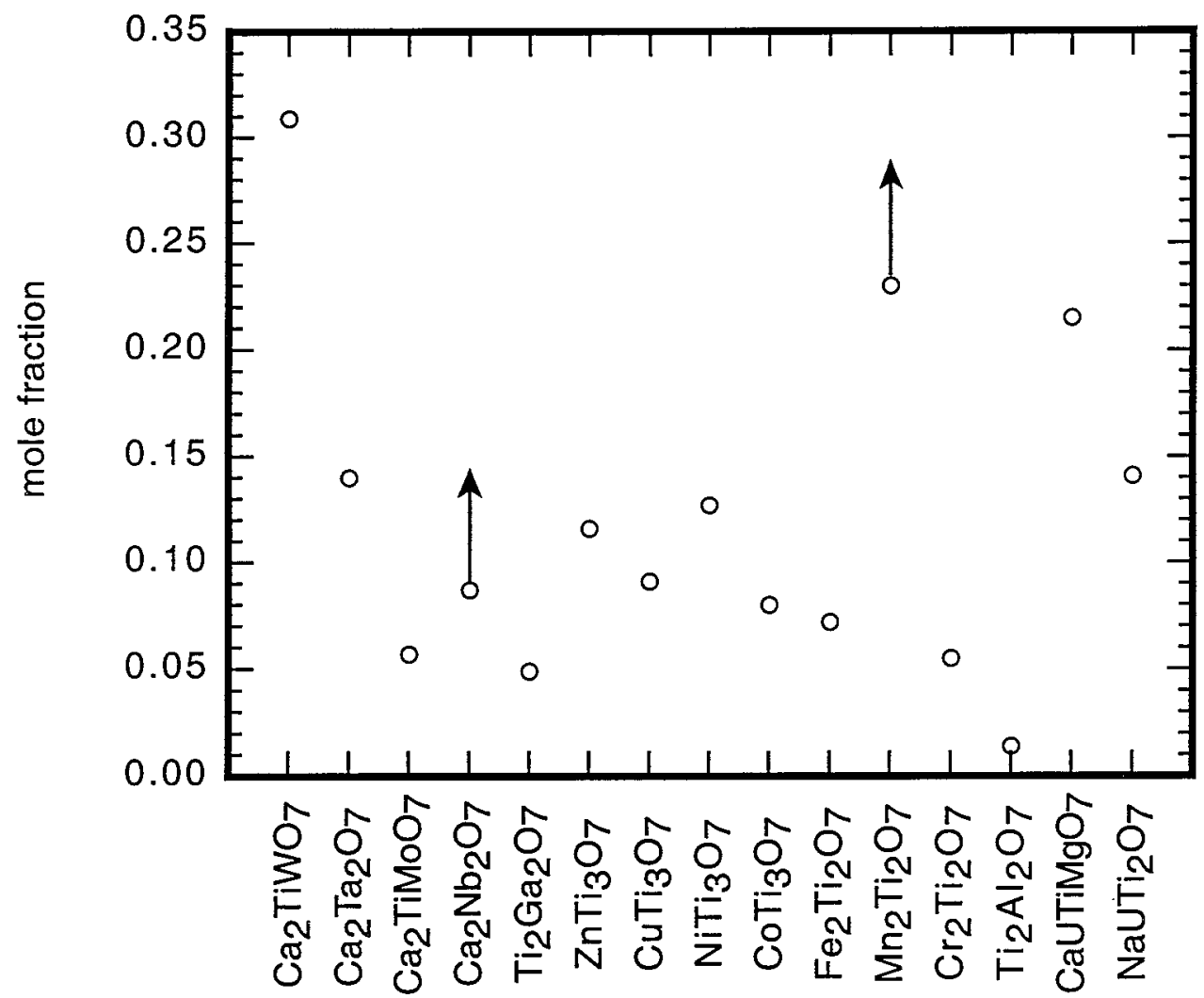

\section{Pyrochlore component}

Figure 1. Saturation limits for various pyrochlore components in accessory phase saturated assemblages synthesized at $1350^{\circ} \mathrm{C}$ in air. The components with "up arrows" are not saturated with an accessory phase, and represent lower bounds.

The components in Table 4 have also been applied to pyrochlores from impuritybearing Pu-Hf-Ce ceramics synthesized at LLNL (Ebbinghaus et al, 2000) (Table 8). We treat plutonium in a fashion identical to cerium, replacing $\mathrm{Ce}_{2} \mathrm{Ti}_{2} \mathrm{O}_{7}$ with $\mathrm{Pu}_{2} \mathrm{Ti}_{2} \mathrm{O}_{7}$, etc. The 
results of the transformation for these compositions is excellent with few negative concentrations and none on absolute magnitude greater than 0.033 . It is also interesting to note that the negative concentrations are observed almost exclusively for $\mathrm{Pu}_{2} \mathrm{Ti}_{2} \mathrm{O}_{7}$. This is consistent with $\mathrm{Pu}$ being present in a higher oxidation state than $\mathrm{Ce}$ at the same redox conditions.

The saturation limits for the components in Table 4 in the nominal baseline pyrochlore, $\mathrm{Ca}_{1.05} \mathrm{Ce} / \mathrm{Pu}_{0.24} \mathrm{Gd}_{0.23} \mathrm{U}_{0.39} \mathrm{Hf}_{0.09} \mathrm{Ti}_{1.89} \mathrm{Al}_{0.01} \mathrm{Hf}_{0.10} \mathrm{O}_{7}$, are plotted in Figure 1. In cases where the saturation limits were not exceeded a limiting value established from the highest concentration measured is given (denoted by "up" arrows on figure). The composition of additives for a particular wastestream can then be established as follows:

1.) Impurity fraction. Cast each of the impurities in its appropriate component and determine the additives required to convert metals to these components.

2.) Baseline fraction. Determine additives to required to convert $\mathrm{Pu}$ to the nominal baseline pyrochlore composition.

3.) Using the masses of the impurity and baseline fractions, determine the mole fraction of each impurity and compare to limits in Figure 1. If a solubility limit is exceeded, dilute mixture with additional baseline fraction additives to comply with limits.

4.) Add rutile component to mixture to obtain desired rutile/pyrochlore ratio. 
Table 7. Pyrochlore nole fractions of impurity runs on Ce-Hf-U and Pu-Hf-U formulation with and without added impurities (Vance et al , 1999)

\begin{tabular}{|c|c|c|c|c|c|c|c|c|c|c|c|c|c|c|c|c|c|c|c|c|c|}
\hline & $\mathrm{NaUTi}_{2} \mathrm{O}_{7}$ & CaUTi & $\mathrm{I}_{2} \mathrm{Al}_{2} \mathrm{O}_{7}$ & $\mathrm{r}_{2} \mathrm{Ti}_{2} \mathrm{O}_{7}$ & $\mathrm{Mn}_{2} \mathrm{Ti}_{2} \mathrm{O}_{7}$ & $\mathrm{Fe}_{2} \mathrm{Ti}_{2} \mathrm{O}_{2}$ & $\mathrm{CoTi}_{3} \mathrm{O}$ & $\mathrm{NiT}_{3} \mathrm{O}_{2}$ & $\mathrm{CuTi}, \mathrm{O}$, & $\mathrm{ZnTi}_{\mathrm{i}} \mathrm{O}_{3}$ & $\mathrm{~T}_{3_{1} \mathrm{Ga}_{2} \mathrm{O}}$ & & 5.8 & $\mathrm{Ca}_{3} \mathrm{Ta}_{\mathrm{O}}$ & & $\overline{\mathrm{Gd}_{2} \mathrm{I}}$ & $\overline{\mathrm{Ce}_{2}}$ & Catf & CaCeTiHfo, & $\mathrm{CaUTi}_{2} \mathrm{O}_{7} \mathrm{C}$ & sos \\
\hline $\mathrm{F}-1$ & 0.000 & 0.060 & 0.000 & 0.000 & 0.000 & 0.000 & 0.080 & 0.030 & 0.000 & 0.000 & 0.000 & 0.000 & 0.000 & 0.000 & 0.000 & 0.125 & 0.000 & -0.020 & 0.230 & 0.385 & 0.130 \\
\hline F-2 Ar bright & 0.000 & 0.060 & 0.000 & 0.000 & 0.030 & 0.020 & 0.080 & 0.030 & 0.000 & 0.000 & 0.000 & 0.000 & 0.000 & 0.000 & 0.000 & 0.135 & -0.025 & -0.080 & 0.270 & 0.420 & 0.080 \\
\hline F-2 Air & 0.000 & 0.050 & 0.000 & 0.000 & 0.025 & 0.015 & 0.060 & 0.000 & 0.000 & 0.000 & 0.000 & 0.000 & 0.000 & 0.000 & 0.000 & 0.110 & -0.038 & 0.095 & 0.205 & 0.355 & 0.150 \\
\hline F-3 & 0.000 & 0.000 & 0.015 & 0.015 & 0.065 & 0.040 & 0.000 & 0.000 & 0.000 & 0.000 & 0.015 & 0.000 & 0.000 & 0.000 & 0.000 & 0.115 & 0.013 & -0.085 & 0.205 & 0.400 & 0.200 \\
\hline F-4 Ar & 0.000 & 0.000 & 0.015 & 0.015 & 0.055 & 0.045 & 0.000 & 0.000 & 0.000 & 0.000 & 0.020 & 0.000 & 0.000 & 0.000 & 0.000 & 0.110 & 0.015 & .0 .060 & 0.180 & 0.485 & 0.130 \\
\hline F-4 Air & 0.000 & 0.000 & 0.015 & 0.015 & 0.055 & 0.020 & 0.000 & 0.000 & 0.000 & 0.000 & 0.015 & 0.000 & 0.000 & 0.000 & 0.000 & 0.105 & -0.007 & -0.175 & 0.275 & 0.365 & 0.330 \\
\hline $\mathrm{F}-43.7 \% \mathrm{H} 2$ & 0.000 & 0.000 & 0.015 & 0.040 & 0.085 & 0.000 & 0.000 & 0.000 & 0.000 & 0.000 & 0.000 & 0.000 & 0.000 & 0.000 & 0.000 & 0.115 & 0.028 & 0.195 & 0.065 & 0.895 & -0.430 \\
\hline F-5 Ar & 0.000 & 0.000 & 0.000 & 0.000 & 0.000 & 0.000 & 0.000 & 0.000 & 0.000 & 0.000 & 0.000 & 0.000 & 0.000 & 0.000 & 0.000 & 0.125 & 0.025 & 0.080 & 0.200 & 0.365 & 0.190 \\
\hline F.5 Air & 0.000 & 0.000 & 0.000 & 0.000 & 0.000 & 0.000 & 0.000 & 0.000 & 0.000 & 0.000 & 0.000 & 0.000 & 0.000 & 0.000 & 0.000 & 0.110 & 0.015 & 0.030 & 0.210 & 0.295 & 0.310 \\
\hline F-5 3.7\%H2 & 0.000 & 0.000 & 0.000 & 0.000 & 0.000 & 0.000 & 0.000 & 0.000 & 0.000 & 0.000 & 0.000 & 0.000 & 0.000 & 0.000 & 0.000 & 0.110 & 0.062 & 0.295 & 0.045 & 0.650 & -0.200 \\
\hline F-6 Ar & 0.000 & 0.000 & 0.000 & 0.000 & 0.000 & 0.000 & 0.000 & 0.000 & 0.000 & 0.000 & 0.000 & 0.110 & 0.000 & 0.140 & 0.000 & 0.125 & 0.108 & 0.105 & 0.025 & 0.465 & -0.090 \\
\hline F-6 Air & 0.000 & 0.000 & 0.000 & 0.000 & 0.000 & 0.000 & 0.000 & 0.000 & 0.000 & 0.000 & 0.000 & 0.105 & 0.000 & 0.135 & 0.000 & 0.115 & 0.085 & 0.100 & 0.060 & 0.430 & -0.020 \\
\hline $\mathrm{F}-63.7 \% \mathrm{H} 2$ & 0.000 & 0.000 & 0.000 & 0.000 & 0.000 & 0.000 & 0.000 & 0.000 & 0.000 & 0.000 & 0.000 & 0.075 & 0.000 & 0.105 & 0.000 & 0.095 & 0.148 & 0.265 & -0.085 & 0.560 & -0.180 \\
\hline $\mathrm{F}-7 \mathrm{Ar}$ & 0.000 & 0.000 & 0.000 & 0.000 & 0.000 & 0.000 & 0.000 & 0.000 & 0.000 & 0.000 & 0.000 & 0.000 & 0.060 & 0.000 & 0.140 & 0.125 & 0.105 & 0.220 & 0.020 & 0.410 & -0.080 \\
\hline F-7 Air & 0.000 & 0.000 & 0.000 & 0.000 & 0.000 & 0.000 & 0.000 & 0.000 & 0.000 & 0.000 & 0.000 & 0.000 & 0.040 & 0.000 & 0.150 & 0.105 & 0.063 & 0.175 & 0.075 & 0.400 & 0.000 \\
\hline $\mathrm{F}-73.7 \% \mathrm{H} 2$ & 0.000 & 0.000 & 0.000 & 0.000 & 0.000 & 0.000 & 0.000 & 0.000 & 0.000 & 0.000 & 0.000 & 0.000 & 0.007 & 0.000 & 0.040 & 0.105 & 0.149 & 0.329 & -0.109 & 0.562 & .0 .104 \\
\hline $\mathrm{F}-8 \mathrm{Ar} *$ & 0.000 & 0.110 & 0.000 & 0.000 & 0.050 & 0.035 & 0.050 & 0.000 & 0.000 & 0.000 & 0.000 & 0.000 & 0.000 & 0.000 & 0.000 & 0.125 & 0.020 & 0.050 & 0.190 & 0.265 & 0.130 \\
\hline F-8 Air* & 0.000 & 0.090 & 0.000 & 0.000 & 0.035 & 0.025 & 0.050 & 0.000 & 0.000 & 0.000 & 0.000 & 0.000 & 0.000 & 0.000 & 0.000 & 0.125 & 0.030 & -0.020 & 0.190 & 0.215 & 0.290 \\
\hline $\mathrm{F}-9 \mathrm{Ar}^{*}$ & 0.000 & 0.000 & 0.000 & 0.025 & 0.065 & 0.040 & 0.000 & 0.000 & 0.000 & 0.000 & 0.000 & 0.000 & 0.000 & 0.000 & 0.000 & 0.105 & 0.055 & 0.000 & 0.130 & 0.335 & 0.250 \\
\hline F-9 Air* & 0.000 & 0.000 & 0.015 & 0.025 & 0.055 & 0.040 & 0.000 & 0.000 & 0.000 & 0.000 & 0.000 & 0.000 & 0.000 & 0.000 & 0.000 & 0.105 & 0.028 & -0.065 & 0.195 & 0.340 & 0.280 \\
\hline $\mathrm{F}-10 \mathrm{Ar} * *$ & 0.000 & 0.000 & 0.000 & 0.000 & 0.000 & 0.000 & 0.000 & 0.000 & 0.000 & 0.000 & 0.000 & 0.000 & 0.000 & 0.000 & 0.000 & 0.115 & -0.005 & 0.220 & 0.230 & 0.395 & 0.050 \\
\hline F-10 Air** & 0.000 & 0.000 & 0.000 & 0.000 & 0.000 & 0.000 & 0.000 & 0.000 & 0.000 & 0.000 & 0.000 & 0.000 & 0.000 & 0.000 & 0.000 & 0.120 & -0.023 & 0.205 & 0.255 & 0.345 & 0.110 \\
\hline $\mathrm{F}-11 \mathrm{Ar}^{*}$ & 0.000 & 0.000 & 0.000 & 0.000 & 0.000 & 0.000 & 0.000 & 0.000 & 0.000 & 0.000 & 0.000 & 0.120 & 0.000 & 0.130 & 0.000 & 0.120 & 0.103 & 0.135 & -0.005 & 0.400 & -0.020 \\
\hline $\mathrm{F}-11 \mathrm{Air} *$ & 0.000 & 0.000 & 0.000 & 0.000 & 0.000 & 0.000 & 0.000 & 0.000 & 0.000 & 0.000 & 0.000 & 0.125 & 0.000 & 0.135 & 0.000 & 0.115 & 0.095 & 0.130 & 0.000 & 0.415 & -0.030 \\
\hline $\mathrm{F}-12 \mathrm{Ar}^{*}$ & 0.000 & 0.040 & 0.000 & 0.000 & 0.000 & 0.020 & 0.000 & 0.000 & 0.000 & 0.000 & 0.000 & 0.000 & 0.040 & 0.000 & 0.160 & 0.130 & 0.090 & 0.180 & 0.020 & 0.345 & -0.030 \\
\hline F-12 Air* & 0.000 & 0.040 & 0.000 & 0.000 & 0.000 & 0.010 & 0.000 & 0.000 & 0.000 & 0.000 & 0.000 & 0.000 & 0.020 & 0.000 & 0.150 & 0.120 & 0.080 & 0.160 & 0.050 & 0.275 & 0.090 \\
\hline F-14 1250 & 0.000 & 0.000 & 0.020 & 0.000 & 0.000 & 0.000 & 0.000 & 0.000 & 0.000 & 0.000 & 0.000 & 0.000 & 0.000 & 0.000 & 0.000 & 0.115 & 0.080 & 0.150 & 0.040 & 0.315 & 0.290 \\
\hline F-14 1300 & 0.000 & 0.000 & 0.025 & 0.000 & 0.000 & 0.000 & 0.000 & 0.000 & 0.000 & 0.000 & 0.000 & 0.000 & 0.000 & 0.000 & 0.000 & 0.115 & 0.063 & 0.175 & 0.045 & 0.460 & 0.120 \\
\hline F-14 1350 & 0.000 & 0.000 & 0.015 & 0.000 & 0.000 & 0.000 & 0.000 & 0.000 & 0.000 & 0.000 & 0.000 & 0.000 & 0.000 & 0.000 & 0.000 & 0.120 & 0.055 & 0.170 & 0.070 & 0.430 & 0.160 \\
\hline $\mathrm{F} \cdot 15+\mathrm{Al}$ & 0.000 & 0.000 & 0.025 & 0.000 & 0.000 & 0.000 & 0.000 & 0.000 & 0.000 & 0.000 & 0.000 & 0.000 & 0.000 & 0.000 & 0.000 & 0.130 & 0.050 & 0.030 & 0.110 & 0.390 & 0.280 \\
\hline $\mathrm{F}-15+\mathrm{B}$ & 0.000 & 0.000 & 0.015 & 0.000 & 0.000 & 0.000 & 0.000 & 0.000 & 0.000 & 0.000 & 0.000 & 0.000 & 0.000 & 0.000 & 0.000 & 0.140 & 0.023 & 0.095 & 0.115 & 0.415 & 0.210 \\
\hline F-15+Na\&K & 0.170 & 0.000 & 0.010 & 0.000 & 0.000 & 0.000 & 0,000 & 0.000 & 0.000 & 0.000 & 0,000 & 0.000 & 0.000 & 0.000 & 0.000 & 0.125 & $\begin{array}{c}-0.038 \\
-0.038\end{array}$ & 0.025 & 0.245 & 0.300 & 0.180 \\
\hline
\end{tabular}


Table 8. Pyrochlore mole fractions of impurity runs on Ce-Hf-U and Pu-Hf-U formulation with and without added impurities (Ebbinghaus et al., 1999)

\begin{tabular}{|c|c|c|c|c|c|c|c|c|c|c|c|c|c|c|c|c|c|c|c|c|c|}
\hline GF 368 A ir* & & & & & & & & & & & & & & & & & & & & & \\
\hline$M \mathrm{MF}^{2688} \mathrm{~A} *$ & 0.000 & 0.000 & 0.000 & 0. & 0.000 & 0.000 & 0.000 & 0.000 & 0.00 & 0.000 & 0.0 & 0.000 & 0.000 & 0.000 & 0.000 & 0.05 & -0.033 & 0.007 & 0.261 & 0.229 & 0.444 \\
\hline $\mathrm{ME} 3688 \mathrm{Ar}^{*}$ & 0.001 & 0.000 & 0.000 & 0.000 & 0.000 & 0.000 & 0.000 & 0.000 & 0.000 & 0.000 & 0.002 & 0.000 & 0.000 & 0.000 & 0.000 & 0.089 & -0.002 & 0.023 & 0.223 & 0.159 & 0.506 \\
\hline ME3688 CO2* & 0.000 & 0.000 & 0.000 & 0.000 & 0.000 & 0.000 & 0.000 & 0.000 & 0.000 & 0.000 & 0.002 & 0.000 & 0.000 & 0.000 & 0.000 & 0.086 & -0.010 & -0.008 & 0.247 & 0.145 & 0.540 \\
\hline ME3692 Air* & 0.000 & 0.146 & 0.000 & 0.000 & 0.000 & 0.000 & 0.000 & 0.000 & 0.000 & 0.000 & 0.000 & 0.000 & 0.000 & 0.000 & 0.000 & 0.121 & 0.005 & 0.130 & 0.132 & 0.271 & 0.195 \\
\hline $\mathrm{ME} 3692 \mathrm{Ar}^{*}$ & 0.000 & 0.132 & 0.000 & 0.000 & 0.000 & 0.000 & 0.000 & 0.000 & 0.000 & 0.000 & 0.002 & 0.000 & 0.000 & 0.000 & 0.000 & 0.123 & 0.005 & 0.129 & 0.148 & 0.246 & 0.217 \\
\hline $\mathrm{ME} 3692 \mathrm{CO}^{*}$ & 0.000 & 0.1 & 0.000 & 0.000 & .000 & 0.000 & 0.000 & 0.000 & 0.000 & 0.000 & 0.001 & 0.000 & 0.000 & 0.000 & 0.000 & 0.119 & 0.040 & 0.115 & 0.136 & 0.175 & 0.278 \\
\hline ME3707 Air* & 0.000 & 0.000 & 0.000 & 0.000 & 0.234 & 0.000 & 0.000 & 0.000 & 0.000 & 0.000 & 0.001 & 0.000 & 0.000 & 0.000 & 0.000 & 0.085 & 0.079 & 0.169 & 0.031 & 0.252 & 0.149 \\
\hline ME3707 Ar* & 0.001 & 0.000 & 0.000 & 0.000 & 0.242 & 0.000 & 0.000 & 0.000 & 0.000 & 0.000 & 0.001 & 0.000 & 0.000 & 0.000 & 0.000 & 0.085 & 0.085 & 0.180 & 0.027 & 0.292 & 0.089 \\
\hline $\mathrm{ME} 3707 \mathrm{CO} 2 \mathrm{r}^{*}$ & 0.000 & 0.000 & 0.000 & 0.000 & 0.245 & 0.000 & 0.000 & 0.000 & 0.000 & 0.000 & 0.000 & 0.000 & 0.000 & 0.000 & 0.000 & 0.085 & 0.078 & 0.180 & 0.030 & 0.297 & 0.085 \\
\hline ME3717 Airr* & 0.000 & 0.000 & 0.000 & 0.063 & 0.000 & 0.000 & 0.000 & 0.000 & 0.000 & 0.000 & 0.002 & 0.000 & 0.000 & 0.000 & 0.000 & 0.119 & 0.077 & 0.075 & 0.095 & 0.203 & 0.367 \\
\hline ME3717Ar* & 0.000 & 0.000 & 0.000 & 0055 & $\mathrm{~cm}$ & 0.000 & 0.000 & 0.000 & 0.000 & 0.000 & 0.000 & 0.000 & 0.000 & 0.000 & 0.000 & 0.105 . & 0.095 & 0.119 & 0.047 & 0.201 & 0.378 \\
\hline ME3717 CO2* & 0.000 & 0.000 & 0.000 & 0.052 & 0.000 & 0.000 & 0.000 & 0.000 & 0.000 & 0.000 & 0.000 & 0.000 & 0.000 & 0.000 & 0.000 & 0.110 & 0.110 & 0.135 & 0.030 & 0.191 & 0.372 \\
\hline
\end{tabular}




\section{Conclusions}

The elements added to the baseline formulation can be divided into two somewhat arbitrary groups - those for which the solubility limits in the baseline phase assemblage are sufficiently low such that expected impurity levels stabilize an accessory mineral, and a second group for which the solubility limits are high enough to allow the element to be accommodated as a solid solution component within the four primary phases. The first group includes $\mathrm{Fe}_{2} \mathrm{O}_{3}, \mathrm{MgO}, \mathrm{Al}_{2} \mathrm{O}_{3}, \mathrm{FeAl}_{2} \mathrm{O}_{4}, \mathrm{MgAl}_{2} \mathrm{O}_{4}, \mathrm{CaAl}_{2} \mathrm{O}_{4}, \mathrm{NiO}, \mathrm{Cr}_{2} \mathrm{O}_{3}, \mathrm{Ga}_{2} \mathrm{O}_{3}$, $\mathrm{MoO}_{3}, \mathrm{WO}_{3}$ which all result in the formation of a crystalline accessory phase at synthesis conditions between $1300-1400^{\circ} \mathrm{C}$. In addition, these components can also have significant solubility in one of the baseline phases; divalent and trivalent cations typically stabilizing hafnolite, while penta- and higher valence cations stabilize pyrochlore. $\mathrm{Fe}_{2} \mathrm{O}_{3}$ may be the most troublesome impurity as it leads to melting at $1350^{\circ} \mathrm{C}$ at the $10 \mathrm{wt} \%$ level. $\mathrm{SiO}_{2}$, $\mathrm{NaAlSiO}_{4}$ and $\mathrm{P}_{2} \mathrm{O}_{5}$ result in the formation of a grain boundary melt at synthesis conditions, and $\mathrm{P}_{2} \mathrm{O}_{5}$ also stabilizes a crystalline, Ca-lanthanide phosphate. $\mathrm{CaO}, \mathrm{MnO}_{2}$ and $\mathrm{Nb}_{2} \mathrm{O}_{5}$ additions do not result in the formation of new phases. $\mathrm{Nb}_{2} \mathrm{O}_{5}$ is highly soluble in pyrochlore and no solubility limit was observed for the compositions investigated here. $\mathrm{CaO}$ reacts with brannerite to form perovskite. $\mathrm{MnO}$ is enriched in pyrochlore, displacing $\mathrm{CaO}$ which again reacts with brannerite to form perovskite.

\section{References}

Armstrong, J.T. CITZAF: a package of correction programs for the quantitative electron microbeam analysis of thick polished materials, thin films and particles. Microbeam Anal., 4, 177-200, 1995.

Ebbinghaus, B.B., C. Cicero-Herman, L. Gray and H. Shaw, Plutonium immobilizaiton project: Baseline Formulation, Lawrence Livermore National Laboratory, 1999.

Lumpkin, G.R., K.P. Hart, P.J. McGlinn, and T.E. Payne, Retention of actinides in natural pyrochlores and zirconolites, Radiochimica Acta, 66/67, 460-474, 1994. 
Morgan PED, Clarke DR, Jantzen CM, Harker AB, High-Alumina Tailored Nuclear Waste Ceramics, Journal of the American Ceramic Society 64: (5) 249-258 1981

Nesbitt HW, Bancroft GM, Fyfe WS, Karkhanis SN, Nishijima, A, Thermodynamic Stability And Kinetics Of Perovskite Dissolution, Nature 289: (5796) 358-362 1981

Ringwood, A.E., S.E. Kesson, N.G. Ware, W. Hibberson, and A. Major, Immobilization of high level nuclear reactor waste in SYNROC, Nature, 278, 219-223, 1979.

Ryerson, F.J., Phase equilibria in nuclear waste ceramics: The effect of oxygen fugacity, $J$. Am. Ceram. Soc, 67, 75-82, 1984.

Subramanian, M.A., G. Aravamudan, and G.V. Subba Rao, Oxide pyrochlores-A review, Progress in Solid State Chemistry, 15, 55-143, 1983. 
Appendix A. Starting Materials

Table 2. Starting materials

\begin{tabular}{|c|c|}
\hline $\mathrm{Al}_{2} \mathrm{O}_{3}$ & $\mathrm{Al}(\mathrm{OH})_{3}$ \\
\hline $\mathrm{CaO}$ & $\mathrm{CaCO}_{3}, \mathrm{CaF}_{2}$ \\
\hline $\mathrm{TiO}_{2}$ & $\mathrm{TiO}_{2}$ (rutile) \\
\hline $\mathrm{HfO}_{2}$ & $\mathrm{HfO}_{2}$ \\
\hline $\mathrm{CeO}_{2}$ & $\left(\mathrm{NH}_{4}\right)_{2} \mathrm{Ce}\left(\mathrm{NO}_{3}\right)_{6}, \mathrm{CeO}_{2}$ \\
\hline $\mathrm{Gd}_{2} \mathrm{O}_{3}$ & $\mathrm{Gd}\left(\mathrm{NO}_{3}\right)_{3} \cdot 6 \mathrm{H}_{2} \mathrm{O}, \mathrm{Gd}_{2} \mathrm{O}_{3}$ \\
\hline $\mathrm{Fe}_{2} \mathrm{O}_{3}$ & $\mathrm{Fe}_{2} \mathrm{O}_{3}$ \\
\hline $\mathrm{MnO}_{2}$ & $\mathrm{MnO}_{2}$ \\
\hline $\mathrm{MgO}$ & $\mathrm{MgO}$ \\
\hline $\mathrm{SiO}_{2}$ & $\mathrm{SiO}_{2}$ \\
\hline $\mathrm{Na}_{2} \mathrm{O}$ & $\mathrm{Na}_{2} \mathrm{CO}_{3}$ \\
\hline $\mathrm{NiO}$ & $\mathrm{NiO}$ \\
\hline $\mathrm{Cr}_{2} \mathrm{O}_{3}$ & $\mathrm{Cr}_{2} \mathrm{O}_{3}$ \\
\hline $\mathrm{Ga}_{2} \mathrm{O}_{3}$ & $\mathrm{Ga}_{2} \mathrm{O}_{3}$ \\
\hline $\mathrm{CuO}$ & $\mathrm{CuO}$ \\
\hline $\mathrm{ZnO}$ & $\mathrm{ZnO}$ \\
\hline $\mathrm{P}_{2} \mathrm{O}_{5}$ & $\mathrm{NH}_{4} \mathrm{H}_{2} \mathrm{PO}_{4}$ \\
\hline $\mathrm{UO}_{2}$ & $\mathrm{UO}_{2}\left(\mathrm{NO}_{3}\right)_{2} 6 \mathrm{H}_{2} \mathrm{O}, \mathrm{UO}_{2}$ \\
\hline
\end{tabular}




\begin{tabular}{ll} 
Appendix B. & Probe standards \\
\hline $\mathrm{MgO}$ & Natural Olivine \\
$\mathrm{Na}_{2} \mathrm{O}$ & Natural Albite \\
$\mathrm{Al}_{2} \mathrm{O}_{3}$ & Corundum \\
$\mathrm{SiO}_{2}$ & Natural Diopside \\
$\mathrm{P}_{2} \mathrm{O}_{5}$ & Natural Apatite \\
$\mathrm{CaO}$ & Natural Wollastonite \\
$\mathrm{TiO}_{2}$ & Rutile \\
$\mathrm{Cr}_{2} \mathrm{O}_{3}$ & Natural Chromite \\
$\mathrm{MnO}$ & Natural Spessartine Garnet \\
$\mathrm{NiO}$ & Synthetic Ni-olivine \\
$\mathrm{Ga}_{2} \mathrm{O}_{3}$ & Gadolinium Gallium Garnet \\
$\mathrm{Nb}_{2} \mathrm{O}_{5}$ & Nb metal \\
$\mathrm{MoO}_{3}$ & CaMoO \\
$\mathrm{HfO}_{2}$ & Hf metal \\
$\mathrm{Ce}_{2} \mathrm{O}_{3}$ & CeO \\
$\mathrm{Gd}_{2} \mathrm{O}_{3}$ & $\mathrm{Gadolinium}$ Gallium Garne \\
$\mathrm{WO}_{3}$ & W metal \\
$\mathrm{UO}_{2}$ & Synthetic $\mathrm{UO}_{2}$
\end{tabular}


Table C1. Microprobe analyses (wt\%) and structural formulae for the Ce-analog with no additives

\begin{tabular}{|c|c|c|c|c|c|c|c|c|c|c|c|c|c|c|c|c|}
\hline Run: & $\begin{array}{r}1-1 \\
\text { Pyrochlore } \\
\end{array}$ & $1300 \mathrm{C}$ & $\begin{array}{r}1-1 \\
\text { Brannerite }\end{array}$ & $1300 \mathrm{C}$ & $\begin{array}{r}1-1 \\
\text { Rutile }\end{array}$ & $1300 \mathrm{C}$ & $\begin{array}{r}1-2 \\
\text { Pyrochlore } \\
\end{array}$ & $1400 \mathrm{C}$ & $\begin{array}{r}1-2 \\
\text { Brannerite } \\
\end{array}$ & $1400 \mathrm{C}$ & $\begin{array}{r}1-2 \\
\text { Rutile }\end{array}$ & $1400 \mathrm{C}$ & $\begin{array}{r}1-3 \\
\text { Pyrochlore }\end{array}$ & $\begin{array}{r}1350 \mathrm{C} \\
9\end{array}$ & $\begin{array}{r}1-3 \\
\text { Rutile }\end{array}$ & $\begin{array}{r}1350 \mathrm{C} \\
3 \\
\end{array}$ \\
\hline & $\mathrm{wt} \%$ & std dev & $\mathrm{wt} \%$ & std dev & wt\% & std dev & wt $\%$ & std dev & wt\% & std dev & $\mathrm{w} 1 \%$ & std dev & wt\% & std dev & w1 \% & std dev \\
\hline $\mathrm{Al}, \mathrm{O}_{2}$ & 0.08 & 0.01 & 0.41 & 0.03 & 0.55 & 0.03 & 0.00 & 0.00 & 0.00 & 0.00 & 0.61 & 0.03 & 0.16 & 0.01 & 0.69 & 0.03 \\
\hline $\mathrm{CaO}$ & 13.25 & 0.18 & 2.19 & 1.22 & 0.14 & 0.04 & 12.62 & 0.14 & 1.34 & 0.04 & 0.07 & 0.03 & 12.53 & 1.17 & 0.01 & 0.01 \\
\hline TiO, & 32.86 & 0.22 & 40.62 & 1.05 & 78.12 & 0.99 & 32.58 & 0.40 & 39.73 & 0.13 & 75.93 & 0.30 & 33.86 & 1.27 & 78.30 & 0.95 \\
\hline $\mathrm{CeO}_{2}$ & 8.53 & 0.24 & 10.19 & 0.38 & 0.10 & 0.02 & 8.75 & 0.12 & 9.66 & 0.02 & 0.08 & 0.02 & 8.87 & 0.60 & 0.04 & 0.02 \\
\hline $\mathrm{Gd}, \mathrm{O}_{2}$ & 8.95 & 0.14 & 7.57 & 0.21 & 0.09 & 0.04 & 9.17 & 0.35 & 6.75 & 0.30 & 0.09 & 0.06 & 9.30 & 0.95 & 0.00 & 0.00 \\
\hline HFO, & 8.98 & 0.32 & 6.43 & 0.53 & 18.34 & 0.60 & 10.47 & 0.20 & 6.41 & 0.09 & 19.41 & 0.29 & 10.23 & 0.47 & 18.50 & 0.85 \\
\hline प्, & 22.97 & 0.59 & 28.80 & 0.56 & 2.21 & 0.10 & .22 .82 & 0.31 & 30.64 & 0.02 & 2.68 & 0.05 & 20.95 & 1.91 & 2.39 & 0.20 \\
\hline Total & $95.62-$ & & 96.20 . & & 99.54 & 0.87 & 96.41 & & $94.51-$ & & 98.89 & & $95.89-$ & & $99.93-$ & \\
\hline $\mathrm{Al}$ & 0.008 & 0.001 & 0.030 & 0.002 & 0.010 & 0.000 & 0.000 & 0.000 & 0.000 & 0.000 & 0.011 & 0.000 & 0.015 & 0.002 & 0.012 & 0.001 \\
\hline $\mathrm{Ca}$ & 1.076 & 0.012 & 0.146 & 0.080 & 0.002 & 0.001 & 1.034 & 0.008 & 0.094 & 0.003 & 0.001 & 0.000 & 1.012 & 0.041 & 0.000 & 0.000 \\
\hline $\mathrm{Ti}$ & 1.873 & 0.015 & 1.915 & 0.069 & 0.899 & 0.003 & 1.873 & 0.015 & 1.960 & 0.010 & 0.891 & 0.002 & 1.925 & 0.059 & 0.898 & 0.006 \\
\hline $\mathrm{Ce}$ & 0.237 & 0.006 & 0.234 & 0.010 & 0.001 & 0.000 & 0.245 & 0.004 & 0.232 & 0.000 & 0.000 & 0.000 & 0.245 & 0.006 & 0.000 & 0.000 \\
\hline $\mathrm{Gd}$ & 0.225 & 0.003 & 0.157 & 0.003 & 0.000 & 0.000 & 0.232 & 0.008 & 0.147 & 0.006 & 0.000 & 0.000 & 0.232 & 0.012 & 0.000 & 0.000 \\
\hline $\mathrm{Hf}$ & 0.194 & 0.007 & 0.115 & 0.008 & 0.080 & 0.003 & 0.228 & 0.004 & 0.120 & 0.002 & 0.086 & 0.001 & 0.221 & 0.005 & 0.081 & 0.004 \\
\hline U & 0.387 & 0.009 & 0.402 & 0.011 & 0.008 & 0.000 & 0.388 & 0.005 & 0.447 & 0.001 & 0.009 & 0.000 & 0.351 & 0.018 & 0.008 & 0.001 \\
\hline Catatoms & 4.000 & 0.000 & 3.000 & 0.000 & 1.000 & 0.000 & $4.000-$ & & $3.000-$ & & 1.000 & & 4.000 & 0.000 & 1.000 & 0.000 \\
\hline Oxygen & 6.690 . & & $5.643-$ & & 1.992 . & & 6.728 - & & 5.717 & & 1.993. & & 6.743 & 0.046 & 1.994 & 0.000 \\
\hline
\end{tabular}

$\underset{\substack{C a \\ \text { Gad }}}{C}$ Sum
Charge

\begin{tabular}{|c|c|c|c|c|c|c|c|c|}
\hline $\mathrm{Ca}$ & 1.076 & 0.146 & 0.002 & 1.034 & 0.094 & 0.001 & 1.012 & 0.000 \\
\hline $\mathrm{Ce}(+3)$ & 0.158 & 0.156 & 0.000 & 0.163 & 0.155 & 0.000 & 0.163 & 0.000 \\
\hline $\mathrm{Ce}(+4)$ & 0.079 & 0.078 & 0.000 & 0.082 & 0.077 & 0.000 & 0.082 & 0.000 \\
\hline $\mathrm{Gd}$ & 0.225 & 0.157 & 0.000 & 0.232 & 0.147 & 0.000 & 0.232 & 0.000 \\
\hline $\mathrm{Hf}$ & 0.075 & 0.061 & 0.000 & 0.101 & 0.080 & 0.000 & 0.160 & 0.000 \\
\hline U & 0.387 & 0.402 & 0.008 & 0.388 & 0.447 & 0.009 & 0.351 & 0.008 \\
\hline Sum & 2.000 & 1.000 & 0.011 & 2.000 & 1.000 & 0.011 & 2.000 & 0.008 \\
\hline Charge & 6.008 & 4.031 & 0.053 & 5.999 & 4.002 & 0.061 & 6.014 & 0.050 \\
\hline $\mathrm{Ti}$ & 1.873 & 1.915 & 0.899 & 1.873 & 1.960 & 0.891 & 1.925 & 0.898 \\
\hline $\mathrm{Hf}$ & 0.119 & 0.054 & 0.080 & 0.127 & 0.040 & $\begin{array}{l}0.086 \\
0.086\end{array}$ & $\begin{array}{l}1.925 \\
0.061\end{array}$ & $\begin{array}{l}0.088 \\
0.081\end{array}$ \\
\hline Al & 0.008 & 0.030 & 0.010 & 0.000 & 0,000 & 0.011 & 0.015 & 0.012 \\
\hline Sum & 2.000 & 2.000 & 2.000 & 2.000 & 2.000 & 2.000 & 2.000 & 2.000 \\
\hline Charge & 7.992 & 7.970 & 3.947 & 8.000 & 8.000 & 3.943 & 7.985 & 3.954 \\
\hline UOx & 2.7 & 2.793 & 3 & 2.595 & 2.55 & 2.8 & 2.615 & 2.8 \\
\hline Model Oxygens & 7.000 & 6.000 & 2.000 & 7.000 & 6.001 & 2.000 & 7.000 & 2.000 \\
\hline
\end{tabular}


Table C2. Microprobe analyses of $\mathrm{Ce}$-analog made from oxides with no additives

\begin{tabular}{|c|c|c|c|c|c|c|c|c|c|c|c|c|}
\hline & $5-1$ & 1300 & 5-1 & 1300 & $5-1$ & 1300 & $5-2$ & 1400 & $5-2$ & 1400 & $5-2$ & 1400 \\
\hline & Pyrochlore & & Brannerite & & Rutile & & Pyrochlore & & Brannerite & & Rutile & \\
\hline & & std dev & & std dev & $w 1 \%$ & std dev & & std dev & & std dev & $w t \%$ & std dev \\
\hline $\mathrm{Al}_{\mathrm{C}, \mathrm{O}_{2}}$ & $\begin{array}{r}0.05 \\
1289\end{array}$ & 0.01 & 0.28 & 0.06 & 0.43 & 0.02 & 0.06 & 0.01 & 0.28 & 0.01 & 0.43 & 0.03 \\
\hline $\mathrm{CaO}$ & 12.89 & 0.51 & 1.42 & 0.12 & 0.05 & 0.02 & 12.90 & 0.09 & 1.34 & 0.07 & 0.08 & 0.05 \\
\hline TiO, & 33.08 & 1.32 & 40.28 & 0.44 & 77.02 & 0.39 & 33.71 & 0.21 & 41.49 & 0.45 & 78.20 & 0.36 \\
\hline $\mathrm{CeO}$, & 8.42 & 0.36 & 9.83 & 0.65 & 0.10 & 0.02 & 8.34 & 0.19 & 9.34 & 0.52 & 0.09 & 0.04 \\
\hline $\mathrm{Gd}, \mathrm{O}_{2}$ & 9.20 & 0.42 & 7.34 & 0.61 & 0.01 & 0.01 & 9.29 & 0.20 & 7.21 & 0.34 & 0.10 & 0.06 \\
\hline $\mathrm{HfO}$, & 8.34 & 0.22 & 6.40 & 0.26 & 19.58 & 0.24 & 10.58 & 0.18 & 6.39 & 0.54 & $\begin{array}{l}0.80 \\
19.83\end{array}$ & 0.29 \\
\hline $\mathrm{UO}_{2}$ & 24.47 & 1.05 & 30.68 & 0.32 & 2.02 & 0.14 & $\begin{array}{r}23.27 \\
\end{array}$ & 0.20 & 31.31 & 0.43 & $\begin{array}{r}2.12 \\
\end{array}$ & 0.11 \\
\hline Total & $96.44-$ & & $96.23-$ & & $99.21-$ & & $98.16-$ & & 97.37 - & & 100.85 & \\
\hline $\mathrm{Al}$ & 0.004 & 0.001 & 0.021 & 0.004 & 0.008 & 0.000 & 0.006 & 0.001 & 0.021 & 0.001 & 0.008 & 0.001 \\
\hline $\mathrm{Ca}$ & 1.052 & 0.036 & 0.097 & 0.007 & 0.001 & 0.000 & 1.032 & 0.007 & $\begin{array}{l}0.091 \\
0.091\end{array}$ & 0.005 & 0.001 & 0.001 \\
\hline $\mathrm{Ti}$ & 1.879 & 0.064 & 1.941 & 0.006 & 0.897 & 0.002 & 1.892 & 0.007 & 1.968 & 0.008 & 0.896 & 0.002 \\
\hline $\mathrm{Ce}$ & 0.235 & 0.008 & 0.231 & 0.014 & 0.001 & 0.000 & 0.228 & 0.005 & 0.216 & 0.012 & 0.001 & 0.000 \\
\hline $\mathrm{Gd}$ & 0.233 & 0.009 & 0.156 & 0.013 & 0.000 & 0.000 & 0.230 & 0.005 & 0.151 & 0.006 & 0.000 & 0.000 \\
\hline $\mathrm{Hf}$ & 0.186 & 0.010 & 0.117 & 0.005 & 0.087 & 0.001 & 0.226 & 0.004 & 0.115 & 0.010 & 0.086 & 0.001 \\
\hline U & 0.412 & 0.016 & 0.437 & 0.007 & 0.007 & 0.000 & 0.386 & 0.004 & 0.439 & 0.003 & $\begin{array}{l}0.007 \\
0.007\end{array}$ & 0.000 \\
\hline Catatoms & 4.000 & 0.000 & 3.000 & 0.000 & 1.000 & 0.000 & 4.000 & & $3.000-$ & & $1.000-$ & \\
\hline Oxyger & $6.712-$ & & 5.699 . & & $1.995=$ & & $6.736-$ & & $5.716-$ & & $1.994-$ & \\
\hline
\end{tabular}

\begin{tabular}{lll} 
Ca & 1.000 & 1.000 \\
Gd & 0.000 & 0.000 \\
\hline Sum & 1.000 & 1.000
\end{tabular}

$\begin{array}{lll}\text { Charge } & 1.000 & 1.000 \\ 2.000 & \end{array}$

\begin{tabular}{|c|c|c|c|c|c|c|}
\hline $\mathrm{Ca}$ & 0.052 & 0.146 & 0.001 & 0.032 & 0.146 & 0.001 \\
\hline $\mathrm{Ce}(+3)$ & 0.235 & 0.231 & 0.001 & 0.228 & 0.216 & 0.001 \\
\hline Gd & 0.233 & 0.157 & 0.000 & 0.230 & 0.157 & 0.000 \\
\hline Hf & 0.106 & 0.079 & 0.007 & 0.106 & 0.103 & 0.006 \\
\hline $\mathrm{U}(+4)$ & 0.199 & 0.187 & 0.001 & 0.087 & 0.220 & 0.001 \\
\hline $\mathrm{U}(+6)$ & 0.213 & 0.250 & 0.006 & 0.299 & 0.219 & 0.006 \\
\hline Sum & 1.037 & 1.042 & 1.042 & 0.982 & 1.042 & 1.042 \\
\hline Charge & 4.004 & 4.005 & 4.005 & 4.005 & 4.005 & 4.005 \\
\hline $\mathrm{Ti}$ & 1.879 & 1.941 & 0.897 & 1.892 & 1.968 & 0.896 \\
\hline $\mathrm{Hf}$ & 0.117 & 0.038 & 0.080 & 0.102 & 0.012 & 0.080 \\
\hline $\mathrm{Al}$ & 0.004 & 0.021 & 0.008 & 0.006 & 0.021 & 0.008 \\
\hline Sum & 2.000 & 2.000 & 2.000 & 2.000 & 2.000 & 2.000 \\
\hline Charge & 7.996 & 7.970 & 3.947 & 7.994 & 7.970 & 3.947 \\
\hline Model Oxygen & 7.000 & 6.000 & 2.001 & 7.000 & 6.000 & 2.000 \\
\hline
\end{tabular}


Table 8. Microprobe analyses of Ce-analog made from oxides with no additives

\begin{tabular}{|c|c|c|c|c|c|c|}
\hline & $5-3$ & 1350 & $5-3$ & 1350 & $5-3$ & 1350 \\
\hline & Pyrochlore & & Brannerite & & Rutile & \\
\hline $\mathrm{Al}, \mathrm{O}_{2}$ & 0.14 & slager & 047 & 002 & 0.55 & s.ter \\
\hline $\mathrm{CaO}$ & 12.93 & 0.10 & 1.47 & 0.14 & 0.02 & 0.01 \\
\hline TiO, & 32.94 & 0.37 & 41.50 & 0.34 & 77.23 & 0.22 \\
\hline $\mathrm{CeO}$, & 8.26 & 0.17 & 9.10 & 0.82 & 0.01 & 0.01 \\
\hline $\mathrm{Gd}_{2} \mathrm{O}_{2}$ & 9.24 & 0.20 & 7.30 & 0.15 & 0.00 & 0.00 \\
\hline $\mathrm{HFO}$, & 10.36 & 0.19 & 6.72 & 0.06 & 19.88 & 0.15 \\
\hline UO, & 23.36 & 0.51 & 31.33 & 0.35 & 2.08 & 0.19 \\
\hline Total & 97.23 & & 97.89 & & $99.75-$ & \\
\hline Al & 0.012 & 0.001 & 0.035 & 0.001 & 0.010 & 0.000 \\
\hline $\mathrm{Ca}$ & 1.045 & 0.004 & 0.099 & 0.006 & 0.000 & 0.000 \\
\hline $\mathrm{Ti}$ & 1.868 & 0.014 & 1.950 & 0.008 & 0.892 & 0.005 \\
\hline $\mathrm{Ce}$ & 0.228 & 0.005 & 0.207 & 0.014 & 0.000 & 0.000 \\
\hline Gd & 0.231 & 0.006 & 0.153 & 0.004 & 0.000 & 0.000 \\
\hline Hf & 0.223 & 0.004 & 0.119 & 0.001 & 0.090 & 0.005 \\
\hline U & 0.392 & 0.009 & 0.437 & 0.003 & & \\
\hline Catatoms & 4.000 & 0.000 & 3.000 & 0.000 & 1.000 & 0.000 \\
\hline Oxygen & 6.719 & & 5.704 . & & $1.995-$ & \\
\hline
\end{tabular}

\begin{tabular}{llll}
$\mathrm{Ca}$ & 1.000 & & \\
$\mathrm{Gd}$ & 0.000 & & \\
\hline Sum & 1.000 & & \\
Charge & 2.000 & 0.146 & 0.000 \\
$\mathrm{Ca}$ & 0.045 & 0.207 & 0.000 \\
$\mathrm{Ce}(+3)$ & 0.228 & 0.157 & 0.000 \\
$\mathrm{Gd}$ & 0.231 & 0.105 & 0.010 \\
$\mathrm{Hf}$ & 0.106 & 0.195 & 0.001 \\
$\mathrm{U}(+4)$ & 0.116 & 0.242 & 0.006 \\
\hline $\mathrm{U}(+6)$ & 0.276 & 1.042 & 1.042 \\
Sum & 1.002 & 4.005 & 4.005 \\
Charge & 4.012 & 1.950 & 0.892 \\
Ti & 1.868 & 0.015 & 0.080 \\
Hf & 0.120 & 2.035 & 2.010 \\
Al & 0.012 & 7.970 & 3.947 \\
Sum & 2.000 & 6.000 & 2.001
\end{tabular}


Table C3. Microprobe analyses (w1\%) of the $\mathrm{Ce}$-analog with $10 \% \mathrm{Al}_{2} \mathrm{O}_{2}$ added

\begin{tabular}{|c|c|c|c|c|c|c|c|c|c|c|c|c|c|c|c|c|}
\hline & 7.1 & 1300 & $7-1$ & 1300 & $7-1$ & 1300 & $7-1$ & 1300 & $7-1$ & 1300 & $7-2$ & 1400 & 7.2 & 1400 & $7-2$ & 1400 \\
\hline & Pyrochlore & std dev & Hafnolite & std dev & Brannerite & $\operatorname{stdey}$ & Corundum & $\operatorname{std} d \mathrm{~d}$ & $\begin{array}{l}\text { Rutile } \\
\text { Rut\% }\end{array}$ & stdd dev & Pyrochlore & std dev & Hafnolite & std dey & Rutile & std dev \\
\hline$\overline{\mathrm{Al}_{1} \mathrm{O}_{2}}$ & 0.30 & 0.15 & 3.81 & 0.45 & 1.13 & $\frac{s e d}{0.02}$ & 100.50 & Stad 0.27 & $\frac{W c \%}{2.14}$ & 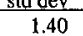 & $\begin{array}{l}\text { Wito } \\
0.34\end{array}$ & $\frac{s a \mathrm{dev}}{0.02}$ & 3.82 & 0.58 & 0.98 & $\frac{\text { sta dev }}{0.15}$ \\
\hline $\mathrm{CaO}$ & 13.59 & 0.09 & 10.01 & 0.45 & 1.29 & 0.02 & 0.16 & 0.17 & 0.17 & 0.06 & 13.08 & 0.09 & 9.62 & 0.51 & 0.56 & 0.57 \\
\hline $\mathrm{TiO}$ & 34.27 & 0.42 & 32.75 & 0.13 & 39.87 & 0.29 & 0.55 & 0.42 & 83.12 & 0.57 & 32.84 & 0.16 & 31.61 & 0.54 & 84.34 & 0.83 \\
\hline $\mathrm{CeO}$ & 9.84 & 0.39 & 3.95 & 0.79 & 10.69 & 0.11 & 0.10 & 0.13 & 0.18 & 0.01 & 8.15 & 0.16 & 3.68 & 0.65 & 0.50 & 0.35 \\
\hline $\mathrm{Gd}_{2} \mathrm{O}_{2}$ & 8.94 & 0.13 & 7.58 & 0.28 & 6.79 & 0.13 & 0.14 & 0.13 & 0.10 & 0.01 & 10.70 & 0.27 & 9.36 & 0.23 & 0.24 & 0.18 \\
\hline $\mathrm{HfO}$, & 6.22 & 0.82 & 31.46 & 2.91 & 4.30 & 0.11 & 0.18 & 0.04 & 11.03 & 0.28 & 8.81 & 0.24 & 31.62 & 2.49 & 9.91 & 0.04 \\
\hline $\mathrm{UO}_{2}$ & 23.98 & 1.27 & 9.08 & 2.30 & 32.38 & 0.26 & 0.30 & 0.34 & 3.38 & 0.16 & 23.85 & 0.25 & 9.72 & 1.79 & 4.34 & 0.91 \\
\hline Total & 97.14 - & & 98.64 - & & 96.44 - & & 101.93 & 0.96 & 100.13 & 1.03 & 97.76 & 0.51 & 99.43 & 0.70 & 100.87 & 1.36 \\
\hline $\mathrm{Al}$ & 0.026 & 0.013 & 0.328 & 0.039 & 0.085 & 0.001 & 1.987 & 0.011 & 0.036 & 0.023 & 0.030 & 0.002 & 0.336 & 0.056 & 0.017 & 0.002 \\
\hline $\mathrm{Ca}$ & 1.072 & 0.012 & 0.783 & 0.035 & 0.088 & 0.002 & 0.003 & 0.003 & 0.003 & 0.001 & 1.049 & 0.006 & 0.754 & 0.039 & 0.009 & 0.009 \\
\hline $\mathrm{Ti}$ & 1.896 & 0.013 & 1.797 & 0.009 & 1.902 & 0.006 & 0.007 & 0.005 & 0.903 & 0.024 & 1.847 & 0.005 & 1.753 & 0.026 & 0.916 & 0.016 \\
\hline $\mathrm{Ce}$ & 0.265 & 0.009 & 0.106 & 0.021 & 0.248 & 0.003 & 0.001 & 0.001 & 0.001 & 0.000 & 0.224 & 0.004 & 0.097 & 0.018 & 0.003 & 0.002 \\
\hline $\mathrm{Gd}$ & 0.218 & 0.003 & 0.183 & 0.006 & 0.143 & 0.002 & 0.001 & 0.001 & 0.000 & 0.000 & 0.265 & 0.006 & 0.229 & 0.007 & 0.001 & 0.001 \\
\hline $\mathrm{Hf}$ & 0.131 & 0.016 & 0.655 & 0.061 & 0.078 & 0.002 & 0.001 & 0.000 & 0.045 & 0.000 & 0.189 & 0.006 & 0.679 & 0.049 & 0.041 & 0.000 \\
\hline u & 0.393 & 0.024 & 0.148 & 0.037 & 0.457 & 0.005 & 0.001 & 0.001 & 0.011 & 0.001 & 0.396 & 0.004 & 0.153 & 0.028 & 0.014 & 0.003 \\
\hline $\begin{array}{l}\text { Catatoms } \\
\text { Oxygen }\end{array}$ & $\begin{array}{l}4.000 \\
6.674 .\end{array}$ & 0.000 & $\begin{array}{l}4.000 \\
6.909-\end{array}$ & 0.000 & $\begin{array}{l}3.000 \\
5.675\end{array}$ & 0.000 & $\begin{array}{l}2.000 \\
3.003-\end{array}$ & 0.000 & $\begin{array}{l}1.000 \\
1.978\end{array}$ & 0.000 & $\begin{array}{l}4.000 \\
6.692\end{array}$ & $\begin{array}{l}0.000 \\
0.006\end{array}$ & $\begin{array}{l}4.000 \\
6.916\end{array}$ & $\begin{array}{l}0.000 \\
0.018\end{array}$ & $\begin{array}{l}1.000 \\
1.981\end{array}$ & $\begin{array}{l}0.000 \\
0.011\end{array}$ \\
\hline $\begin{array}{l}\mathrm{Ca} \\
\mathrm{Gd} \\
\end{array}$ & $\begin{array}{l}1.000 \\
0.000 \\
\end{array}$ & & $\begin{array}{l}0.783 \\
0.183 \\
\end{array}$ & & & & & & & & $\begin{array}{l}1.000 \\
0.000\end{array}$ & & $\begin{array}{l}0.754 \\
0.229 \\
\end{array}$ & & & \\
\hline $\begin{array}{l}\text { Sum } \\
\text { Charge }\end{array}$ & $\begin{array}{l}1.000 \\
2.000\end{array}$ & & $\begin{array}{l}0.966 \\
2.116\end{array}$ & & & & & & & & $\begin{array}{l}1.000 \\
2000\end{array}$ & & 0.982 & & & \\
\hline & & & & & & & & & & & & & & & & \\
\hline $\mathrm{Ca}$ & 0.072 & & 0.000 & & 0.146 & & & & & & 0.049 & & 0.000 & & & \\
\hline $\mathrm{Ce}(+3)$ & 0.265 & & 0.106 & & 0.248 & & & & & & 0.224 & & 0.097 & & & \\
\hline $\mathrm{Gd}$ & 0.218 & & 0.000 & & 0.157 & & & & & & 0.265 & & 0.000 & & & \\
\hline $\mathrm{HF}$ & 0.106 & & 0.655 & & 0.065 & & & & & & 0.106 & & 0.679 & & & \\
\hline $\mathrm{U}(+4)$ & 0.174 & & 0.057 & & 0.212 & & & & & & 0.168 & & 0.069 & & & \\
\hline$\underline{U}+6)$ & 0.219 & & 0.091 & & 0.245 & & & & & & 0.228 & & 0.084 & & & \\
\hline $\begin{array}{l}\text { Sum } \\
\text { Charge }\end{array}$ & $\begin{array}{l}1.053 \\
4.026\end{array}$ & & $\begin{array}{l}0.908 \\
3.710\end{array}$ & & $\begin{array}{l}1.073 \\
4.085\end{array}$ & & & & & & 1.040 & & $\begin{array}{l}0.929 \\
3786\end{array}$ & & & \\
\hline $\mathrm{Ti}$ & 1896 & & 1707 & & 1007 & & 0,007 & & 0.903 & & 1847 & & 173 & & 0.916 & \\
\hline $\mathrm{Hf}$ & 0.078 & & 0.000 & & 0.013 & & 0.001 & & 0.045 & & $\begin{array}{l}1.1241 \\
0.123\end{array}$ & & 0.000 & & 0.080 & \\
\hline Al & 0.026 & & 0.328 & & 0.085 & & 1.987 & & 0.036 & & 0.030 & & 0.336 & & 0.017 & \\
\hline Sum & 2.000 & & 2.125 & & 2.000 & & 1.995 & & 2.000 & & 2.000 & & 2.089 & & 2.000 & \\
\hline Charge & 7.974 & & 8.174 & & 7.915 & & 5.991 & & 3.904 & & 7.970 & & 8.020 & & 4.034 & \\
\hline Model Oxygen & 7.000 & & 7.000 & & 6.000 & & 2.996 & & 1.952 & & 7.000 & & 7.000 & & 2.017 & \\
\hline
\end{tabular}


Table C3. Microprobe analyses (w1\%) of the Ce-analog with $10 \% \mathrm{Al}_{2} \mathrm{O}_{2}$ added

\begin{tabular}{|c|c|c|c|c|c|c|c|c|c|c|}
\hline & $7-2$ & 1400 & $7-3$ & 1350 & $7-3$ & 1350. & $7-3$ & 1350 & $7-3$ & $\frac{1350}{2}$ \\
\hline & $\begin{array}{r}\text { Brannerite? } \\
\text { wt\% }\end{array}$ & std dev & $\begin{array}{r}\text { Pyrochlore } \\
\text { wt\% }\end{array}$ & $\begin{array}{r}4 \\
\text { std dev } \\
\end{array}$ & $\begin{array}{r}\text { Brannerite } \\
\text { wt\% }\end{array}$ & $\begin{array}{r}3 \\
\text { std dev } \\
\end{array}$ & $\begin{array}{r}\text { Hafnolite } \\
\text { wt } \%\end{array}$ & $\begin{array}{r}3 \\
\text { std dev }\end{array}$ & $\begin{array}{r}\text { Psuedobrookite } \\
\text { wt\% }\end{array}$ & $\begin{array}{r}2 \\
\text { std dev }\end{array}$ \\
\hline $\mathrm{Al}, \mathrm{O}_{2}$ & 0.00 & 0.00 & 0.32 & 0.01 & 1.44 & 0.05 & 4.35 & 0.18 & 56.74 & 1.75 \\
\hline $\mathrm{CaO}$ & 3.22 & 0.93 & 13.41 & 0.11 & 1.25 & 0.05 & 10.13 & 0.54 & 0.02 & 0.02 \\
\hline $\mathrm{TiO}_{2}$ & 20.55 & 2.28 & 34.77 & 0.35 & 40.27 & 0.09 & 33.43 & 0.11 & 42.09 & 2.11 \\
\hline $\mathrm{CeO}_{2}$ & 19.50 & 1.65 & 9.89 & 0.35 & 10.28 & 0.18 & 4.25 & 0.56 & 0.00 & 0.00 \\
\hline $\mathrm{Gd}_{\mathrm{O}} \mathrm{O}_{3}$ & 3.23 & 0.74 & 8.72 & 0.22 & 6.30 & 0.24 & 7.40 & 0.40 & 0.00 & 0.00 \\
\hline $\mathrm{HfO}$, & 5.60 & 0.53 & 7.10 & 0.07 & 5.08 & 0.13 & 30.43 & 2.36 & 0.00 & 0.00 \\
\hline $\mathrm{UO}_{2}$ & 43.21 & 1.99 & 23.62 & 0.72 & 32.68 & 0.26 & 9.55 & 1.41 & 0.00 & \\
\hline Total & 95.29 & 3.56 & $97.83-$ & & $97.30-$ & & 99.52 - & & 98.85 & 0.33 \\
\hline $\mathrm{Al}$ & 0.000 & 0.000 & 0.028 & 0.001 & 0.107 & 0.004 & 0.368 & 0.013 & 2.036 & 0.053 \\
\hline $\mathrm{Ca}$ & 0.269 & 0.072 & 1.051 & 0.005 & 0.084 & 0.003 & 0.775 & 0.025 & 0.001 & 0.001 \\
\hline $\mathrm{Ti}$ & 1.211 & 0.157 & 1.912 & 0.013 & 1.897 & 0.002 & 1.799 & 0.006 & 0.964 & 0.053 \\
\hline $\mathrm{Ce}$ & 0.559 & 0.037 & 0.265 & 0.008 & 0.236 & 0.003 & 0.112 & 0.010 & 0.000 & 0.000 \\
\hline $\mathrm{Gd}$ & 0.084 & 0.018 & 0.211 & 0.004 & 0.131 & 0.005 & 0.175 & 0.006 & 0.000 & 0.000 \\
\hline $\mathrm{Hf}$ & 0.125 & 0.009 & 0.148 & 0.002 & 0.091 & 0.002 & 0.616 & 0.039 & 0.000 & 0.000 \\
\hline U & 0.753 & 0.020 & 0.384 & 0.013 & 0.456 & 0.004 & 0.155 & 0.016 & 0.000 & 0.000 \\
\hline Catatoms & $3.000-$ & & 4.000 & .0 .000 & 3.000 & 0.000 & 4.000 & 0.000 & 3.000 & 0.000 \\
\hline Oxyzen & $5.410-$ & & $6.697-$ & & 5.680 & & 6.897 - & & 4.982 & \\
\hline $\begin{array}{l}\mathrm{Ca} \\
\mathrm{Gd}\end{array}$ & & & $\begin{array}{l}1.000 \\
0.000\end{array}$ & & & & $\begin{array}{l}0.775 \\
0.175\end{array}$ & & & \\
\hline $\begin{array}{l}\text { Sum } \\
\text { Charge }\end{array}$ & & & $\begin{array}{l}1.000 \\
2.000\end{array}$ & & & & $\begin{array}{l}0.950 \\
2.075\end{array}$ & & & \\
\hline $\mathrm{Ca}$ & 0.269 & & 0.051 & $\cdots$ & 0.084 & & 0.000 & & & \\
\hline $\mathrm{Ce}(+3)$ & 0.559 & & 0.265 & & 0.236 & & 0.112 & & & \\
\hline Gd & 0.084 & & 0.211 & & 0.131 & & 0.000 & & & \\
\hline $\mathrm{Hf}$ & 0.000 & & 0.106 & & 0.091 & & 0.616 & & & \\
\hline$U(+4)$ & 0.163 & & 0.116 & & 0.136 & & 0.052 & & & \\
\hline $\mathrm{U}(+6)$ & 0.590 & & 0.268 & & 0.320 & & 0.103 & & & \\
\hline $\begin{array}{l}\text { Sum } \\
\text { Charge }\end{array}$ & $\begin{array}{l}3.792 \\
4.005\end{array}$ & & $\begin{array}{l}2.914 \\
4.027\end{array}$ & & $\begin{array}{l}2.658 \\
4.005\end{array}$ & & $\begin{array}{l}3.111 \\
3.625\end{array}$ & & & \\
\hline $\mathrm{Ti}$ & 1211 & & 1912 & & 1897 & & 1799 & & 0.96 & \\
\hline $\begin{array}{l}11 \\
\mathbf{H f}\end{array}$ & $\begin{array}{l}1.111 \\
0.125\end{array}$ & & $\begin{array}{l}1.012 \\
0.060\end{array}$ & & 0.000 & & 0.000 & & 0.000 & \\
\hline Al & 0.000 & & 0.028 & & 0.107 & & 0.368 & & 2,036 & \\
\hline Sum & $\begin{array}{l}1.336 \\
5.345\end{array}$ & & 2.000 & & 2.004 & & 2.167 & & $\begin{array}{l}2.999 \\
9.962\end{array}$ & \\
\hline Charge & 5.345 & & 7.972 & & 7.908 & & 8.301 & & 9.962 & \\
\hline Model Oxygen & 6.000 & & 7.000 & & 6.000 & & 7.000 & & 4.981 & \\
\hline
\end{tabular}


Table C4. Microbrobe analyses ( $w t \%$ and structural formulae for the $\mathrm{Ce}$-analog with $10 \mathrm{wt} \% \mathrm{Fe}_{2} \mathrm{O}_{2}$ added

\begin{tabular}{|c|c|c|c|c|c|c|c|c|}
\hline & 4-1. & 1300 & $4-1$ & 1300 & $4-1$ & 1300 & $4-1$ & 1300 \\
\hline & $\begin{array}{l}\text { Pvrochlore } \\
\text { wit } \%\end{array}$ & sed dey & Hafnolite & and de & Brannerite & ad day & Ilmenite & std dev \\
\hline$\overline{\mathrm{Al}, \mathrm{O}_{2}}$ & 0.05 & 0.00 & 0.37 & 0.01 & $\begin{array}{l}\mathrm{w} \% \\
0.16 \\
\end{array}$ & $\frac{-01}{0.01}$ & $\frac{\mathrm{W}+1 \%}{1.97}$ & 0.04 \\
\hline $\mathrm{CaO}$ & 13.87 & 0.12 & 8.40 & 0.14 & 1.56 & 0.34 & 0.14 & 0.04 \\
\hline $\mathrm{TiO}_{2}$ & 33.92 & 0.26 & 36.66 & 0.33 & 38.18 & 0.25 & 39.04 & 0.51 \\
\hline $\mathrm{FeO}$ & 2.35 & 0.10 & 10.98 & 0.13 & 3.07 & 0.09 & 51.81 & 0.29 \\
\hline $\mathrm{CeO}$ & 9.44 & 0.34 & 6.57 & 0.18 & 10.30 & 0.23 & 0.09 & 0.04 \\
\hline $\mathrm{Gd}_{2} \mathrm{O}_{3}$ & 6.18 & 0.10 & 7.39 & 0.40 & 4.74 & 0.14 & 0.06 & 0.03 \\
\hline HFO, & 3.51 & 0.08 & 16.41 & 0.53 & 2.33 & 0.11 & 1.43 & 0.08 \\
\hline & 27.61 & 0.44 & 10.82 & 0.39 & 34.38 & 0.33 & 0.12 & 0.05 \\
\hline Total & $96.92-$ & & 97.58 - & & 94.72 - & & 94.66 & 0.48 \\
\hline $\mathrm{Al}$ & 0.004 & 0.000 & 0.030 & 0.001 & 0.012 & 0.000 & 0.061 & 0.001 \\
\hline $\mathrm{Ca}$ & 1.080 & 0.004 & 0.619 & 0.009 & 0.107 & 0.023 & 0.004 & 0.001 \\
\hline Ti & 1.854 & 0.012 & 1.897 & 0.014 & 1.841 & 0.014 & 0.776 & 0.007 \\
\hline $\mathrm{Fe}$ & 0.143 & 0.006 & 0.632 & 0.005 & 0.165 & 0.005 & 1.146 & 0.006 \\
\hline $\mathrm{Ce}$ & 0.251 & 0.009 & 0.165 & 0.005 & 0.242 & 0.005 & 0.001 & 0.000 \\
\hline $\mathrm{Gd}$ & 0.149 & 0.002 & 0.169 & 0.009 & 0.101 & 0.003 & 0.001 & 0.000 \\
\hline $\mathrm{Hf}$ & 0.073 & 0.001 & 0.322 & 0.012 & 0.043 & 0.002 & 0.011 & 0.001 \\
\hline U & 0.446 & 0.007 & 0.166 & 0.006 & 0.491 & 0.005 & 0.001 & 0.000 \\
\hline Catatoms & 4.000 & 0.000 & 4.000 & 0.000 & 3.000 & 0.000 & 2.000 & 0.000 \\
\hline Oxygen & $6.432-$ & & 5.935 - & & 5.386 & & 1.673 & \\
\hline $\mathrm{Ca}$ & 1.000 & & 0.619 & & & & & \\
\hline $\mathrm{Ce}$ & 0.000 & & 0.165 & & & & & \\
\hline $\mathrm{Fe}$ & 0.000 & & 0.000 & & & & & \\
\hline $\mathrm{Gd}$ & 0.000 & & 0.169 & & & & & \\
\hline Hf & 0.000 & & 0.000 & & & & & \\
\hline $\mathrm{U}$ & 0.000 & & 0.047 & & & & & \\
\hline Sum & 1.000 & & 1.000 & & & & & \\
\hline Charge & 2.000 & & 2.427 & & & & & \\
\hline $\mathrm{Al}$ & 0.000 & & 0.000 & & 0.000 & & 0.000 & \\
\hline Ca & 0.000 & & 0.000 & & 0.107 & & 0.000 & \\
\hline $\mathrm{Fe}(+2)$ & 0.074 & & 0.558 & & 0.000 & & 0.961 & \\
\hline $\mathrm{Ce}(+3)$ & 0.251 & & 0.000 & & 0.242 & & 0.000 & \\
\hline $\mathrm{Gd}$ & 0.149 & & 0.000 & & 0.101 & & 0.000 & \\
\hline $\mathrm{Hf}$ & 0.000 & & 0.322 & & 0.000 & & 0.000 & \\
\hline $\mathrm{U}(+4)$ & 0.000 & & 0.000 & & 0.013 & & 0.000 & \\
\hline$U(+6)$ & 0.446 & & 0.119 & & 0.478 & & 0.000 & \\
\hline Sum & 0.920 & & 1.000 & & 0.000 & & 0.000 & \\
\hline Charge & 3.998 & & 3.680 & & 0.000 & & 0.000 & \\
\hline $\mathrm{Ti}$ & 1.854 & & 1.897 & & 1.841 & & 0.776 & \\
\hline $\mathrm{Hf}$ & 0.073 & & 0.000 & & 0.000 & & 0.011 & \\
\hline Al & 0.004 & & 0.030 & & 0.012 & & 0.061 & \\
\hline $\mathrm{Fe}(+3)$ & 0.069 & & 0.073 & & 0.147 & & 0.185 & \\
\hline Sum & 2.000 & & 2.000 & & 2.000 & & 0.848 & \\
\hline Charge & 7,927 & & 7.897 & & 7.841 & & 3.768 & \\
\hline Model Oxygen & 6.976 & & 6.723 & & 6.000 & & 1.994 & \\
\hline
\end{tabular}


Table CS. Microprobe compositions (wt\%) and structural formulae for a Ce-analog with $10 \mathrm{wt} \% \mathrm{MgO}$ added

\begin{tabular}{|c|c|c|c|c|c|c|c|c|c|c|c|c|c|c|}
\hline & $6-1$ & 1300 & $6-1$ & 1300 & $6-1$ & 1300 & 6-1 & 1300 & 6-2 & 1400 & 6-2 & 1400 & 6-2 & 1400 \\
\hline & $\begin{array}{l}\text { Pvrochlore } \\
\text { wt\% }\end{array}$ & std dev & $\begin{array}{r}\text { Perovskite } \\
\text { w1\% }\end{array}$ & std dev & $\begin{array}{l}\text { Hafnolite } \\
\text { wt } \%\end{array}$ & std dev & $\begin{array}{c}\text { MeTiO3 } \\
\text { wt\% }\end{array}$ & std dev & $\begin{array}{r}\text { Pyrochlore } \\
w 1 \%\end{array}$ & std dev & $\begin{array}{c}\mathrm{Mg} 2 \mathrm{TiO} \\
\mathrm{wt} \%\end{array}$ & std dey & $\begin{array}{l}\text { MgTiOz } \\
\text { Mwt }\end{array}$ & std dev \\
\hline $\mathrm{MgO}$ & 1.29 & 0.06 & 1.76 & 0.07 & 3.91 & 0.09 & 33.88 & 0.17 & 1.89 & 0.02 & 47.50 & 0.22 & 32.04 & $\begin{array}{c}\text { sid dov } \\
0.22\end{array}$ \\
\hline $\mathrm{Al} 2 \mathrm{O} 3$ & 0.02 & 0.01 & 0.24 & 0.02 & 0.05 & 0.00 & 0.14 & 0.00 & 0.00 & 0.00 & 0.82 & 0.02 & 0.00 & 0.00 \\
\hline $\mathrm{CaO}$ & 12.51 & 0.07 & 30.98 & 0.35 & 6.79 & 0.15 & 0.30 & 0.05 & 11.86 & 0.07 & 0.02 & 0.04 & 0.11 & 0.04 \\
\hline TiO2 & 25.06 & 0.78 & 49.40 & 0.38 & 19.97 & 0.38 & 64.79 & 0.38 & 27.24 & 0.19 & $\begin{array}{r}0.02 \\
48.36\end{array}$ & 0.21 & $\begin{array}{r}0.11 \\
64.29\end{array}$ & 0.33 \\
\hline $\mathrm{CeO} 2$ & 9.35 & 0.40 & 6.11 & 0.62 & 5.69 & 0.25 & 0.10 & 0.05 & 8.98 & 0.18 & $\begin{array}{r}0.00 \\
0.00\end{array}$ & 0.00 & 0.00 & 0.00 \\
\hline $\mathrm{Gd} 2 \mathrm{O} 3$ & 9.25 & 0.65 & 10.00 & 1.20 & 8.73 & 0.75 & 0.14 & 0.03 & 9.23 & 0.13 & 0.00 & 0.00 & 0.00 & 0.00 \\
\hline $\mathrm{HfO} 2$ & 12.73 & 1.85 & 1.51 & 0.15 & 30.17 & 2.42 & 4.06 & 0.11 & 12.18 & 0.24 & 0.97 & 0.06 & 2.88 & 0.07 \\
\hline UO2 & 26.55 & 0.33 & 0.28 & 0.08 & 22.71 & $\begin{array}{l}1.72 \\
\text { n }\end{array}$ & 0.09 & 0.05 & 26.36 & 0.26 & 0.00 & $\begin{array}{l}0.00 \\
\end{array}$ & 0.00 & 0.00 \\
\hline Total & $96.74-$ & & 100.28 & 0.31 & $98.03-$ & & 103.50 & & 97.74 & 0.35 & 97.66 & 0.32 & 99.32 & 0.45 \\
\hline $\mathrm{Mg}$ & 0.153 & 0.007 & 0.066 & 0.003 & 0.498 & 0.008 & 1000 & 0.001 & 0.218 & 0.002 & 1.959 & 0.003 & 0.984 & 0.003 \\
\hline Al & 0.001 & 0.000 & 0.007 & 0.001 & 0.005 & 0.001 & 0.003 & 0.000 & 0.000 & 0.000 & 0.027 & 0.001 & $\begin{array}{l}0.000 \\
0.00\end{array}$ & 0.000 \\
\hline $\mathrm{Ca}$ & 1.068 & 0.009 & 0.837 & 0.006 & 0.621 & 0.010 & 0.006 & 0.001 & 0.983 & 0.004 & 0.000 & 0.001 & 0.003 & 0.001 \\
\hline $\mathrm{Ti}$ & 1.501 & 0.036 & 0.937 & 0.004 & 1.283 & 0.014 & 0.965 & 0.003 & 1.585 & 0.010 & 1.006 & 0.003 & 0.996 & 0.003 \\
\hline $\mathrm{Ce}$ & 0.273 & 0.010 & 0.056 & 0.006 & 0.178 & 0.009 & 0.001 & 0.000 & 0.254 & 0.005 & 0.000 & 0.000 & 0.000 & 0.000 \\
\hline Gd & 0.244 & 0.016 & 0.084 & 0.010 & 0.247 & 0.019 & 0.001 & 0.000 & 0.237 & 0.004 & 0.000 & 0.000 & 0.000 & 0.000 \\
\hline $\mathrm{Hf}$ & 0.290 & 0.044 & 0.011 & 0.001 & 0.736 & 0.065 & 0.023 & 0.001 & 0.269 & 0.005 & 0.008 & 0.000 & 0.017 & 0.000 \\
\hline U & 0.471 & 0.008 & 0.002 & 0.000 & 0.432 & 0.030 & 0.000 & 0.000 & 0.454 & 0.005 & 0.000 & 0.000 & 0.000 & 0.000 \\
\hline $\begin{array}{l}\text { Catatoms } \\
\text { Oxygen }\end{array}$ & $\begin{array}{l}4.000 \\
6.520\end{array}$ & 0.000 & $\begin{array}{l}2.000 \\
3.023\end{array}$ & 0.000 & $\begin{array}{l}4.000 \\
6.666-\end{array}$ & 0.000 & 2.000 & 0.000 & 4.000 & & $3.000-$ & & $2.000-$ & \\
\hline $\mathrm{Ca}_{3}$ & 1000 & & & & 0601 & & & & 0093 & & & & & \\
\hline $\begin{array}{l}\mathrm{Ca} \\
\mathrm{Gd}\end{array}$ & $\begin{array}{l}1.000 \\
0.000\end{array}$ & & & & $\begin{array}{l}0.621 \\
0.247\end{array}$ & & & & $\begin{array}{l}0.983 \\
0.017\end{array}$ & & & & & \\
\hline $\mathrm{Ce}(+3)$ & 0.000 & & & & 0.132 & & & & 0.000 & & & & & \\
\hline $\mathrm{U}(+4)$ & 0.000 & & & & 0.000 & & & & 0.000 & & & & & \\
\hline Sum & 1.000 & & & & 1.000 & & & & 1.000 & & & & & \\
\hline Charge & 2.000 & & & & 2.379 & & & & 2.017 & & & & & \\
\hline $\mathrm{Mg}$ & 0.000 & & 0.066 & & 0.000 & & 1.000 & & 0.000 & & & & & \\
\hline $\mathrm{Ca}$ & 0.068 & & 0.837 & & 0.000 & & & & 0.000 & & & & & \\
\hline $\mathrm{Ce}(+3)$ & 0.273 & & 0.056 & & 0.046 & & & & 0.254 & & & & & \\
\hline Gd & 0.244 & & 0.084 & & $\begin{array}{l}0.040 \\
0.000\end{array}$ & & & & $\begin{array}{l}0.254 \\
0.237\end{array}$ & & & & & \\
\hline $\mathrm{Hf}$ & 0.000 & & $\begin{array}{l}0.004 \\
0.000\end{array}$ & & 0.522 & & & & $\begin{array}{l}0.237 \\
0.000\end{array}$ & & & & & \\
\hline$U(+4)$ & 0.000 & & 0.002 & & 0.098 & & & & 0.031 & & & & & \\
\hline$U(+6)$ & 0.471 & & 0.000 & & 0.334 & & & & $\begin{array}{l}.031 \\
0.423\end{array}$ & & & & & \\
\hline Sum & 1.055 & & 1.045 & & 1.000 & & 1.000 & & 0.945 & & & & & \\
\hline Charge & 4.509 & & 2.231 & & 4.622 & & 2.000 & & 4.133 & & & & & \\
\hline $\mathrm{Ti}$ & 1.501 & & 0.937 & & 1.283 & & 0.965 & & 1.585 & & & & & \\
\hline Hf & 0.290 & & 0.011 & & 0.214 & & 0.023 & & 0.269 & & & & & \\
\hline $\mathrm{Mg}$ & 0.153 & & 0.000 & & 0.498 & & & & 0.218 & & & & & \\
\hline Al & 0.001 & & 0.007 & & 0.005 & & 0.003 & & 0.000 & & & & & \\
\hline$\frac{m}{\text { Sum }}$ & 1.945 & & 0.955 & & 2.000 & & 0.991 & & 2.072 & & & & & \\
\hline Charge & 7.472 & & 3.813 & & 6.999 & & 3.962 & & 7.851 & & & & & \\
\hline Model Oxygen & 6.990 & & 3.022 & & 7.000 & & & & 7.000 & & & & & \\
\hline
\end{tabular}


Table C5. Microprobe compositions ( $\mathrm{wt} \%$ ) and structural formulae for a Ce-analog with $10 \mathrm{wt} \% \mathrm{MgO}$ added

\begin{tabular}{|c|c|c|c|c|c|c|c|c|}
\hline & 6.3 & 1350 & 6.3 & 1350 & $6-3$ & 1350 & $6-3$ & 1350 \\
\hline & Pyrochlore & std dey & Perovskite & & M22TiO4 & & MgTiO3 & std dev \\
\hline $\mathrm{MgO}$ & 1.85 & 0.11 & $\frac{1.73}{1.73}$ & 0.04 & $\begin{array}{r}\frac{w t \%}{49.68} \\
\end{array}$ & 0.14 & 33.59 & 0.27 \\
\hline $\mathrm{Al} 2 \mathrm{O} 3$ & 0.03 & 0.01 & 0.18 & 0.05 & 1.44 & 0.03 & 0.06 & 0.00 \\
\hline $\mathrm{CaO}$ & 12.04 & 0.12 & 30.45 & 0.25 & 0.06 & 0.08 & 0.15 & 0.02 \\
\hline $\mathrm{TiO} 2$ & 25.75 & 0.52 & 49.97 & 0.15 & 47.58 & 0.32 & 64.25 & 0.51 \\
\hline $\mathrm{CeO} 2$ & 9.07 & 0.31 & 7.36 & 0.10 & 0.00 & 0.00 & 0.00 & 0.00 \\
\hline $\mathrm{Gd} 2 \mathrm{O} 3$ & 9.08 & 0.20 & 8.29 & 0.44 & 0.00 & 0.00 & 0.00 & 0.00 \\
\hline $\mathrm{HfO} 2$ & 13.56 & 1.14 & 0.88 & 0.17 & 1.29 & 0.09 & 3.06 & 0.13 \\
\hline UO2 & 26.47 & 0.51 & 0.18 & 0.06 & 0.01 & 0.01 & 0.00 & 0.00 \\
\hline Total & 97.84 & & $99.04-$ & & 100.06 & & 101.13 - & \\
\hline $\mathrm{Mg}$ & 0.215 & 0.011 & 0.066 & 0.001 & 1.984 & 0.007 & 1.006 & 0.007 \\
\hline $\mathrm{Al}$ & 0.003 & 0.001 & 0.005 & 0.001 & 0.045 & 0.001 & 0.001 & 0.000 \\
\hline $\mathrm{Ca}$ & 1.009 & 0.011 & 0.830 & 0.003 & 0.002 & 0.002 & 0.003 & 0.000 \\
\hline $\mathrm{Ti}$ & 1.514 & 0.025 & 0.954 & 0.005 & 0.959 & 0.006 & 0.971 & 0.007 \\
\hline $\mathrm{Ce}$ & 0.260 & 0.007 & 0.069 & 0.001 & 0.000 & 0.000 & 0.000 & 0.000 \\
\hline Gd & 0.235 & 0.005 & 0.069 & 0.003 & 0.000 & 0.000 & 0.000 & 0.000 \\
\hline Hf & 0.303 & 0.027 & 0.007 & 0.001 & 0.010 & 0.001 & 0.018 & 0.001 \\
\hline$\underline{U}$ & 0.461 & 0.010 & 0.001 & 0.000 & 0.000 & 0.000 & 0.000 & 0.000 \\
\hline Catatom & 4.000 & 0.000 & 2.000 & 0.000 & 3.000 & 0.000 & 2.000 & 0.000 \\
\hline Oxygen & 6.527 - & & 3.033 & & 3.991 . & & 2.990 . & \\
\hline
\end{tabular}

$\begin{array}{ll}\mathrm{Ca} & 1.000 \\ \mathrm{Gd} & 0.000 \\ \mathrm{Ce}(+3) & 0.000\end{array}$

$\begin{array}{ll}\mathrm{Ce}(+3) & 0.000 \\ \mathrm{U}(+4) & 0.000\end{array}$

$\begin{array}{ll}\text { Sum } & 1.000 \\ \text { Charge } & 2.000\end{array}$

$\begin{array}{lllll}\mathrm{Mg} & 0.000 & 0.066 & 1.984 & 1.006 \\ \mathrm{Ca} & 0.009 & 0.830 & & \\ \mathrm{Ce}(+3) & 0.260 & 0.069 & & \\ \mathrm{Gd} & 0.235 & 0.069 & & \\ \mathrm{Hf} & 0.000 & 0.000 & & \\ \mathrm{U}(++4) & 0.000 & 0.001 & 1.984 & 1.006 \\ \mathrm{U}(+6) & 0.461 & 0.000 & 3.068 & \\ \text { Sum } & 0.964 & 2.206 & 0.959 & 0.971 \\ \mathrm{Charge} & 4.266 & 0.954 & 0.010 & 0.018 \\ \mathrm{Ti} & & 0.007 & 0.045 & 0.001 \\ \mathrm{Hi} & 1.514 & 0.000 & 1.014 & 0.990 \\ \mathrm{Mg} & 0.303 & 0.005 & 4.011 & 3.960 \\ \mathrm{Al} & 0.003 & 0.966 & & \end{array}$

Model Oxygen

6.987

3.032 
Table C6. Microprobe analyses of Ce-analog with 10 wi\% NiO

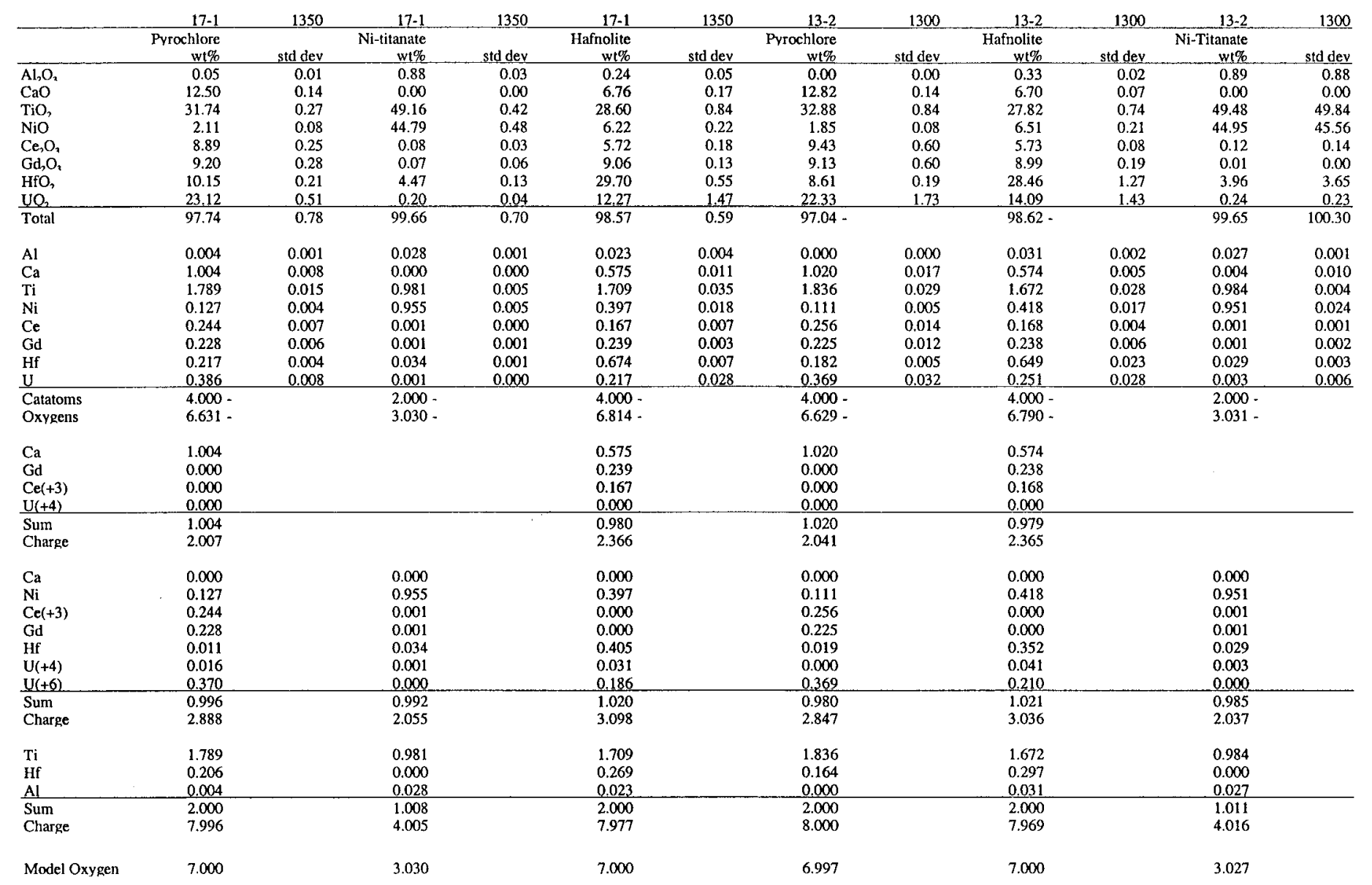


Table C7. Microprobe analyses of Ce-analog with $10 \mathrm{wt} \% \mathrm{CuO}$

\begin{tabular}{|c|c|c|c|c|c|c|c|c|}
\hline & $21-1$ & 1350 & $21-1$ & 1350 & $21-2$ & 1300 & $21-2$ & 1300 \\
\hline & Pyrochlore & & Rutile & & Pyrochlore & & Rutile & \\
\hline & $w 1 \%$ & std dev & $w t \%$ & std dev & wt\% & stad dev & $w t \%$ & std dev \\
\hline $\mathrm{Al}_{1} \mathrm{O}_{2}$ & 0.06 & 0.02 & 0.37 & 0.02 & 0.05 & 0.01 & 0.36 & 0.07 \\
\hline $\mathrm{CaO}$ & 12.23 & 0.10 & 0.02 & 0.03 & 12.74 & 0.09 & 0.02 & 0.03 \\
\hline TiO, & 33.77 & 0.28 & 77.53 & 0.32 & 33.11 & 0.32 & 79.99 & 0.99 \\
\hline $\mathrm{CuO}$ & 1.64 & 0.08 & 0.12 & 0.01 & 1.14 & 0.04 & 0.10 & 0.02 \\
\hline $\mathrm{Ce}_{2} \mathrm{O}_{2}$ & 8.39 & 0.34 & 0.04 & 0.02 & 8.93 & 0.21 & 0.04 & 0.03 \\
\hline $\mathrm{Gd}, \mathrm{O}_{2}$ & 10.02 & 0.18 & 0.00 & 0.00 & 10.04 & 0.32 & 0.00 & 0.00 \\
\hline HfO, & 12.03 & 0.76 & 19.03 & 0.41 & 9.83 & 0.28 & 16.78 & 0.63 \\
\hline $\mathrm{wO}_{2}$ & 22.30 & 0.42 & 1.26 & 0.12 & 24.35 & 0.38 & 1.57 & 0.39 \\
\hline Total & 100.44 & & 98.37 & & 100.18 & & $98.87-$ & \\
\hline $\mathrm{Al}$ & 0.005 & 0.002 & 0.007 & 0.000 & 0.004 & 0.000 & 0.006 & 0.001 \\
\hline $\mathrm{Ca}$ & 0.960 & 0.009 & 0.000 & 0.000 & 1.006 & 0.005 & 0.000 & 0.001 \\
\hline $\mathrm{Ti}$ & 1.861 & 0.008 & 0.903 & 0.003 & 1.835 & 0.014 & 0.914 & 0.006 \\
\hline $\mathrm{Cu}$ & 0.091 & 0.005 & 0.001 & 0.000 & 0.063 & 0.002 & 0.001 & 0.000 \\
\hline $\mathrm{Ce}$ & 0.225 & 0.008 & 0.000 & 0.000 & 0.241 & 0.005 & 0.000 & 0.000 \\
\hline Gd & 0.243 & 0.004 & 0.000 & 0.000 & 0.245 & 0.007 & 0.000 & 0.000 \\
\hline Hf & 0.252 & 0.015 & 0.084 & 0.002 & 0.207 & 0.006 & 0.073 & 0.003 \\
\hline$\underline{U}$ & 0.364 & 0.007 & 0.004 & 0.000 & 0.399 & 0.007 & 0.005 & 0.001 \\
\hline Catatoms & $4.000-$ & & 1.000 & & $4.000-$ & & $1.000-$ & \\
\hline Oxygen & $6.713-$ & & $1.995-$ & & 6.686 & & $1.995-$ & \\
\hline $\mathrm{Ca}$ & 0.960 & & & & 1.006 & & & \\
\hline $\mathrm{Gd}$ & 0.040 & & & & 0.000 & & & \\
\hline $\mathrm{Ce}(+3)$ & 0.000 & & & & 0.000 & & & \\
\hline $\mathrm{U}(+4)$ & 0.000 & & & & 0.000 & & & \\
\hline Sum & 1.000 & & & & 1.006 & & & \\
\hline Charge & 2.040 & & & & 2.011 & & & \\
\hline $\mathrm{Ca}$ & 0.000 & & & & 0.000 & & & \\
\hline $\mathrm{Cu}$ & 0.091 & & & & 0.063 & & & \\
\hline $\mathrm{Ce}(+3)$ & 0.225 & & & & 0.241 & & & \\
\hline Gd & 0.204 & & & & 0.245 & & & \\
\hline $\mathrm{Hf}$ & 0.117 & & & & 0.046 & & & \\
\hline$U(+4)$ & 0.077 & & & & 0.112 & & & \\
\hline$U(+6)$ & 0.287 & & & & 0.287 & & & \\
\hline Sum & 1.000 & & & & 0.994 & & & \\
\hline Charge & 3.103 & & & & 3.078 & & & \\
\hline $\mathrm{Ti}$ & 1.861 & & 0.903 & & 1.835 & & 0.914 & \\
\hline $\mathrm{Hf}$ & 0.134 & & 0.084 & & 0.161 & & 0.073 & \\
\hline $\mathrm{Al}$ & 0.005 & & 0.007 & & 0.004 & & 0.006 & \\
\hline & 2.000 & & 0.994 & & 2.000 & & 0.993 & \\
\hline Charge & 7.995 & & 3.968 & & 7.996 & & 3.965 & \\
\hline Model Oxygen & 7.000 & & 1.984 & & 6.973 & & 1.983 & \\
\hline
\end{tabular}


Table C8. Microprobe analyses of Ce-analog with $10 \mathrm{wt} \% \mathrm{ZnO}$

\begin{tabular}{|c|c|c|c|c|c|c|c|c|}
\hline & $22-1$ & 1350 & $22-1$ & 1350 & $22-2$ & 1300 & $22-2$. & 1300 \\
\hline & Pyrochlore & & Rutile & & Pyrochlore & & Hafnolite & \\
\hline & & std dev & $w t \%$ & sidd dev & & std dev & wt\% & std dev \\
\hline $\mathrm{Al}_{1} \mathrm{O}_{2}$ & 0.10 & 0.04 & 0.48 & 0.05 & 0.00 & 0.00 & 0.34 & 0.05 \\
\hline $\mathrm{CaO}$ & 12.39 & 0.32 & 0.06 & 0.06 & 14.16 & 0.15 & 7.95 & 0.22 \\
\hline $\mathrm{TiO}_{2}$ & $34.2 \mathrm{t}$ & 0.21 & 78.79 & 0.67 & 37.26 & 0.22 & 40.00 & 1.19 \\
\hline $\mathrm{ZnO}$ & 0.34 & 0.02 & 0.00 & 0.00 & 2.25 & 0.11 & 7.63 & $\begin{array}{l}1.19 \\
0.39\end{array}$ \\
\hline $\mathrm{Ce}, \mathrm{O}_{2}$ & 8.66 & 0.26 & 0.06 & 0.05 & 9.00 & 0.16 & 6.53 & 0.21 \\
\hline $\mathrm{Gd}, \mathrm{O}_{3}$ & 10.06 & 0.37 & 0.00 & 0.00 & 7.73 & 0.08 & 8.60 & 0.45 \\
\hline HfO, & 12.10 & 1.03 & 19.00 & 0.34 & 4.78 & 0.32 & 18.89 & 0.58 \\
\hline UO, & 22.07 & 0.64 & 1.69 & 0.28 & 24.24 & 0.22 & $\begin{array}{l}11.94 \\
\end{array}$ & 0.82 \\
\hline Total & 99.92 & 0.37 & 100.08 & 0.49 & $99.41-$ & & 101.90 & \\
\hline Al & 0.008 & 0.003 & 0.009 & 0.001 & 0.000 & 0.000 & 0.028 & 0.004 \\
\hline $\mathrm{Ca}$ & 0.979 & 0.022 & 0.001 & 0.001 & 1.056 & 0.008 & 0.588 & 0.010 \\
\hline $\mathrm{Ti}$ & 1.898 & 0.012 & 0.902 & 0.004 & 1.950 & 0.003 & 2.077 & 0.045 \\
\hline $\mathrm{Zn}$ & 0.018 & 0.001 & 0.000 & 0.000 & 0.116 & 0.006 & 0.389 & $\begin{array}{l}0.019 \\
0.019\end{array}$ \\
\hline $\mathrm{Ce}$ & 0.234 & 0.006 & 0.000 & 0.000 & 0.229 & 0.004 & 0.165 & 0.005 \\
\hline $\mathrm{Gd}$ & 0.246 & 0.010 & 0.000 & 0.000 & 0.178 & 0.002 & 0.197 & 0.011 \\
\hline $\mathrm{Hf}$ & 0.255 & 0.022 & 0.083 & 0.002 & 0.095 & 0.006 & 0.372 & 0.011 \\
\hline $\mathrm{U}$ & 0.362 & 0.010 & 0.006 & 0.001 & 0.375 & 0.004 & 0.184 & 0.013 \\
\hline Catatoms & $4.000-$ & & 1.000 & & 4.000 & & $4.000-$ & \\
\hline Oxygen & $6.759-$ & & 1.995 - & & $6.625-$ & & 6.828 . & \\
\hline $\mathrm{Ca}$ & 0.979 & & & & 1.056 & & 0.588 & \\
\hline Gd & 0.021 & & & & 0.000 & & 0.197 & \\
\hline $\mathrm{Ce}(+3)$ & 0.000 & & & & 0.000 & & 0.165 & \\
\hline$U(+4)$ & 0.000 & & & & 0.000 & & 0.000 & \\
\hline Sum & 1.000 & & & & 1.056 & & 0.950 & \\
\hline Charge & 2.021 & & & & 2.111 & & 2.263 & \\
\hline $\mathrm{Al}$ & 0.000 & & & & 0.000 & & 0.028 & \\
\hline $\mathrm{Ca}$ & 0.000 & & & & 0.000 & & 0.000 & \\
\hline $\mathrm{Cu}$ & 0.018 & & & & 0.116 & & 0.389 & \\
\hline $\mathrm{Ce}(+3)$ & 0.234 & & & & 0.229 & & 0.000 & \\
\hline $\mathrm{Gd}$ & 0.225 & & & & 0.178 & & 0.000 & \\
\hline $\mathrm{Hf}$ & 0.161 & & & & 0.046 & & 0.372 & \\
\hline $\mathrm{U}(+4)$ & 0.121 & & & & 0.000 & & 0.012 & \\
\hline $\mathrm{U}(+6)$ & 0.241 & & & & 0.375 & & 0.172 & \\
\hline Sum & 1.000 & & & & 0.944 & & 0.945 & \\
\hline Charge & 3.264 & & & & 2.763 & & 2.829 & \\
\hline Ti & 1.898 & & 0.902 & & 1.950 & & 2.077 & \\
\hline $\mathrm{Hf}$ & 0.094 & & 0.083 & & 0.049 & & 0.000 & \\
\hline Al & 0.008 & & 0.009 & & 0.000 & & 0.000 & \\
\hline Sum & 2.000 & & 0.993 & & 2.000 & & 2.077 & \\
\hline Charge & 7.992 & & 3.964 & & 8.000 & & 8.308 & \\
\hline Model Oxygen & 7.000 & & 1.982 & & 7.000 & & 7.000 & \\
\hline
\end{tabular}


Table C9. Microprobe analyses of Ce-analog with $10 \mathrm{w} \% \mathrm{Cr}_{2} \mathrm{O}_{3}$

\begin{tabular}{|c|c|c|c|c|c|c|c|c|c|c|c|c|}
\hline & $18-1$ & 1350 & $18-1$ & 1350 & $18-1$ & 1350 & $18-2$ & 1300 & $18-2$ & 1300 & $-18-2$ & -1300 \\
\hline & Pyrochlore & & Hafnolite & & rutile & & Pyrochlore & & Hafnolite & & Rutile & \\
\hline & wt\% & std dev & wt\% & stddev & w1\% & std dev & wt\% & std dev & w1\% & std dev & wt\% & std dev \\
\hline$\overline{\mathrm{Al}, \mathrm{O}_{2}}$ & 0.07 & 0.01 & 0.57 & 0.02 & 0.10 & 0.03 & 0.09 & 0.04 & 0.56 & 0.02 & 0.07 & 0.04 \\
\hline $\mathrm{CaO}$ & 12.99 & 0.12 & 9.52 & 0.13 & 0.25 & 0.43 & 1291 & 0.045 & 958 & 0.02 & 0.07 & 0.04 \\
\hline TiO, & 31.60 & 0.18 & 29.79 & 0.41 & 62.75 & 2.79 & 31.48 & 0.50 & 29.93 & 0.57 & 62.44 & 1.07 \\
\hline $\mathrm{Cr}_{2} \mathrm{O}_{3}$ & 1.88 & 0.10 & 5.76 & 0.33 & 8.51 & 0.87 & 1.84 & 0.31 & 5.84 & 0.24 & 8.49 & 0.09 \\
\hline $\mathrm{Ce}, \mathrm{O}_{2}$ & 9.78 & 0.20 & 3.59 & 0.11 & 0.23 & 0.26 & 9.93 & 0.34 & 3.54 & 0.09 & 0.16 & 0.07 \\
\hline $\mathrm{Gd}, \mathrm{O} 3$ & 10.48 & 0.15 & 7.42 & 0.47 & 0.18 & 0.35 & 10.61 & 0.45 & 7.63 & 0.63 & 0.07 & 0.12 \\
\hline $\mathrm{HfO}$, & 8.98 & 0.35 & 34.46 & 1.60 & 14.20 & 0.92 & 9.39 & 3.09 & 34.57 & 2.24 & 13.23 & 0.63 \\
\hline Uo, & 24.41 & $\begin{array}{l}0.29 \\
\end{array}$ & 9.29 & 0.50 & 11.97 & $\begin{array}{l}.739 \\
1.39\end{array}$ & 23.96 & 1.17 & $\begin{array}{r}9.17 \\
9.19\end{array}$ & 0.67 & 12.97 & 0.57 \\
\hline Total & 100.18 & & 100.41 . & & 98.20 - & & $100.21-$ & & 100.84 & & 97.61 - & \\
\hline $\mathrm{Al}$ & 0.006 & 0.001 & 0050 & 0.002 & 0.002 & 0.001 & 0.008 & 0.003 & 0.049 & 0.002 & 0001 & 0001 \\
\hline $\mathrm{Ca}$ & 1.025 & 0.008 & 0.763 & 0.011 & 0.004 & 0.007 & 1.020 & 0.029 & 0.763 & 0.009 & 0.003 & 0.002 \\
\hline $\mathrm{Ti}$ & 1.751 & 0.009 & 1.672 & 0.017 & 0.771 & 0.019 & 1.746 & 0.028 & 1.674 & 0.022 & 0.774 & 0.009 \\
\hline $\mathrm{Cr}$ & 0.109 & 0.006 & 0.341 & 0.019 & 0.110 & 0.013 & 0.107 & 0.018 & $\begin{array}{l}1.0 .44 \\
0.343\end{array}$ & 0.014 & 0.111 & 0.002 \\
\hline $\mathrm{Ce}$ & 0.264 & 0.005 & 0.098 & 0.003 & 0.001 & 0.001 & 0.268 & 0.010 & 0.096 & 0.002 & 0.001 & 0.000 \\
\hline Gd & 0.256 & 0.004 & 0.183 & 0.011 & 0.001 & 0.002 & 0.259 & 0.011 & 0.188 & 0.015 & 0.000 & 0.001 \\
\hline Hf & 0.189 & 0.007 & 0.739 & 0.039 & 0.066 & 0.005 & 0.198 & 0.064 & 0.734 & 0.052 & 0.062 & 0.003 \\
\hline u & 0.400 & 0.005 & 0.155 & 0.008 & 0.044 & 0.006 & 0.393 & 0.021 & 0.152 & 0.010 & 0.048 & 0.002 \\
\hline $\begin{array}{l}\text { Catatoms } \\
\text { Oxygen }\end{array}$ & $\begin{array}{l}4.000- \\
6.657-\end{array}$ & & $\begin{array}{l}4.000 \\
6.902-\end{array}$ & & $1.000-$ & & $\begin{array}{l}4.000- \\
6.658-\end{array}$ & & $\begin{array}{l}4.1 .12 \\
6.8008 \\
6.898\end{array}$ & & $\begin{array}{l}0.040- \\
1.040-\end{array}$ & \\
\hline
\end{tabular}

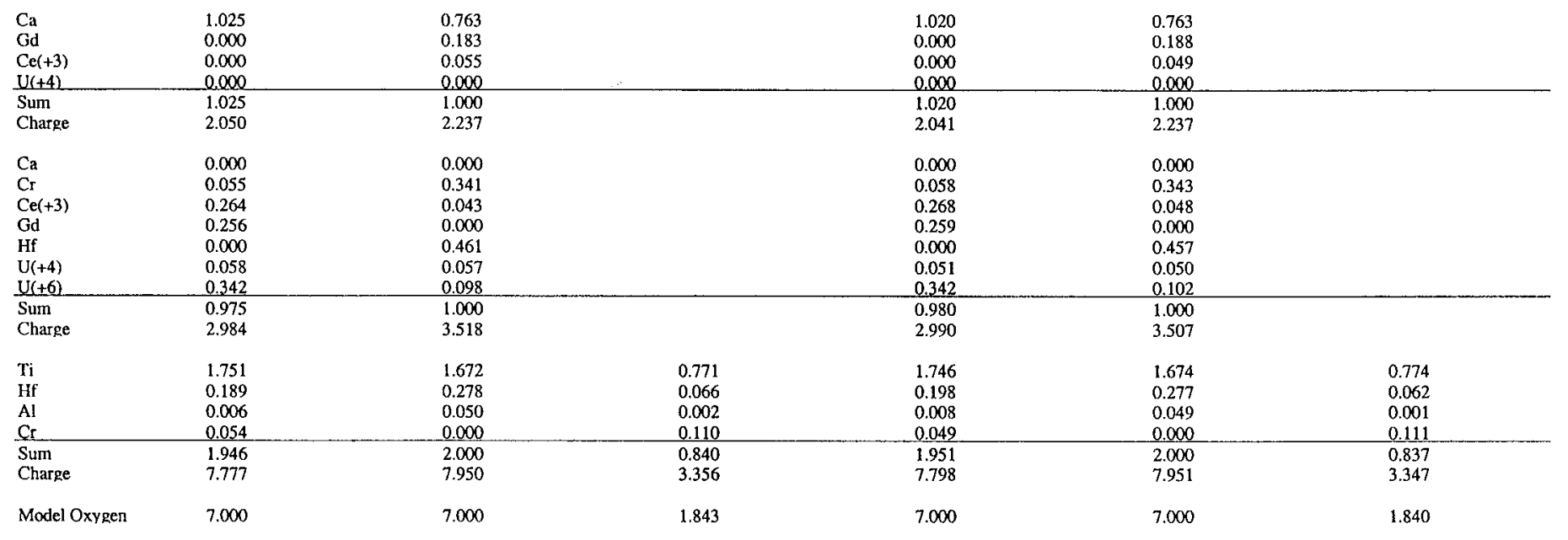


Table Cl0. Microprobe analyses of Ce-antalog with $10 \mathrm{wt} \% \mathrm{FeAl}_{2} \mathrm{O}_{4}$

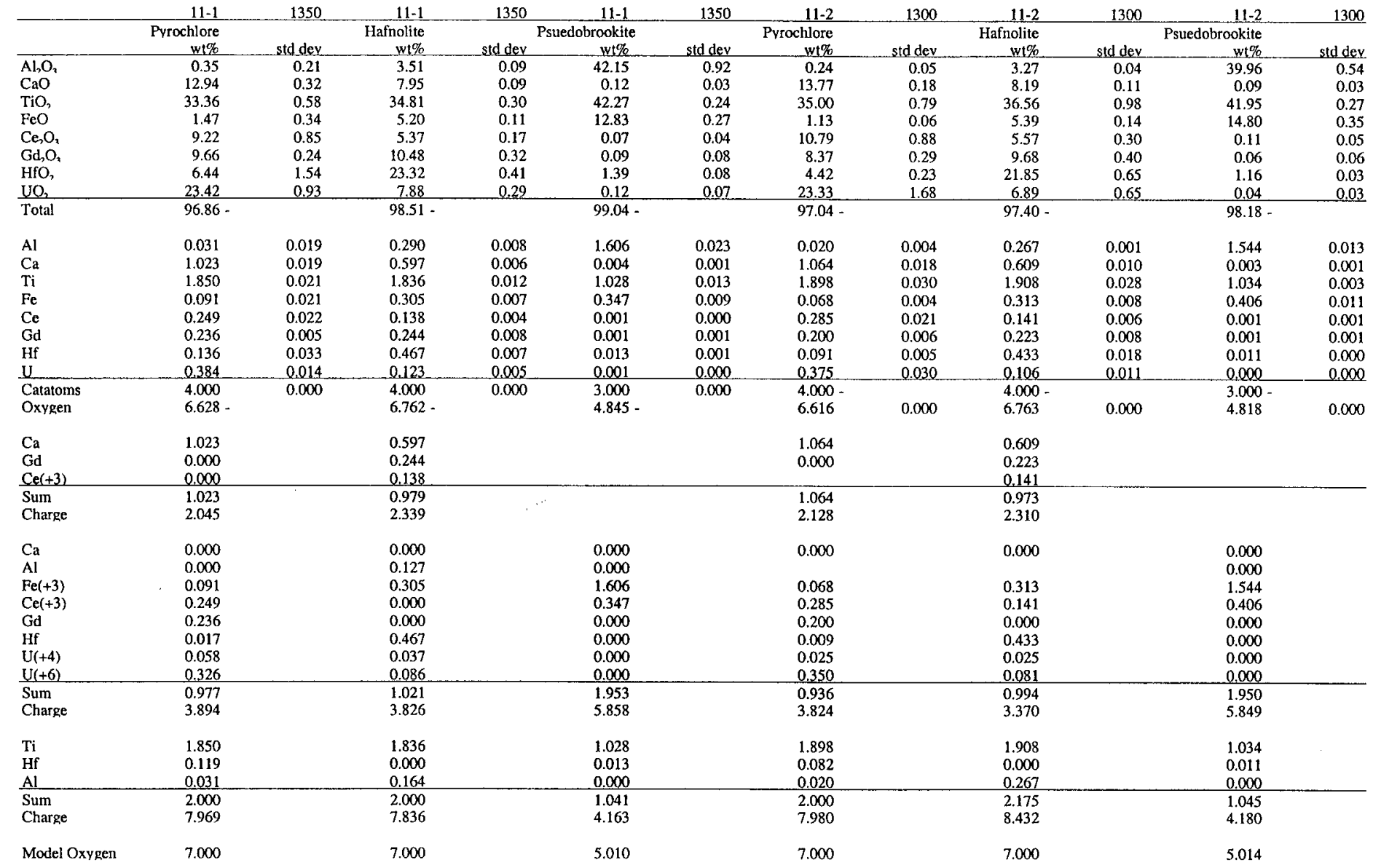


Table C11. Microprobe analyses of Ce-analog with $10 \mathrm{wt} \% \mathrm{MgAl}_{2} \mathrm{O}_{4}$

\begin{tabular}{|c|c|c|c|c|c|c|c|c|c|c|}
\hline & $12-1$ & 1350 & $12-1$ & 1350. & $12-2$ & 1300 & $12-2$ & 1300 & $12-2$ & 1300 \\
\hline & $\begin{array}{r}\text { Pyrochlore } \\
w 1 \%\end{array}$ & $\mathrm{std} d e v$ & $\begin{array}{c}\text { Psuedobrookite } \\
\text { w1\% }\end{array}$ & & $\begin{array}{r}\text { Pyrochlore } \\
\text { wt\% }\end{array}$ & std dev & $\begin{array}{c}\text { Psuedobrookite } \\
\text { wt\% }\end{array}$ & & Hafnolite & \\
\hline $\mathrm{MgO}$ & 0.83 & 0.07 & 9.67 & 0.38 & 0.74 & 0.09 & 10.13 & 0.19 & 1.48 & 0.06 \\
\hline $\mathrm{Al}, \mathrm{O}_{2}$ & 0.31 & 0.03 & 28.50 & 4.20 & 0.24 & 0.01 & 26.50 & 1.33 & 2.49 & 0.43 \\
\hline $\mathrm{CaO}$ & 12.47 & 0.19 & 0.36 & 0.47 & 12.98 & 0.36 & 0.21 & 0.08 & 8.80 & 0.42 \\
\hline $\mathrm{TiO}_{2}$ & 34.39 & 0.64 & 58.24 & 4.06 & 34.50 & 0.76 & 60.39 & 0.71 & 31.54 & 0.63 \\
\hline $\mathrm{Ce}_{2} \mathrm{O}_{2}$ & 9.37 & 0.39 & 0.27 & 0.33 & 9.37 & 0.45 & 0.08 & 0.07 & 4.71 & 0.34 \\
\hline $\mathrm{Gd}_{2} \mathrm{O}_{3}$ & 9.04 & 0.44 & 0.00 & 0.00 & 8.65 & 0.28 & 0.08 & 0.03 & 8.79 & 0.94 \\
\hline $\mathrm{HfO}$ & 7.56 & 0.15 & 3.28 & 0.26 & 6.32 & 0.22 & 3.04 & 0.13 & 30.59 & 1.53 \\
\hline UO, & 22.57 & 1.36 & 0.11 & 0.04 & 23.95 & 1.54 & 0.12 & 0.08 & 12.46 & 1.15 \\
\hline Total & 96.53 & & 100.44 & & 96.74 - & & 100.55 & & 100.86 & \\
\hline $\mathrm{Mg}$ & 0.091 & 0.008 & 0.464 & 0.025 & 0.081 & 0.010 & 0.488 & 0.013 & 0.162 & 0.005 \\
\hline Al & 0.027 & 0.002 & 1.078 & 0.131 & 0.020 & 0.001 & 1.008 & 0.040 & 0.216 & 0.042 \\
\hline $\mathrm{Ca}$ & 0.982 & 0.013 & 0.012 & 0.015 & 1.017 & 0.020 & 0.007 & 0.003 & 0.693 & 0.024 \\
\hline $\mathrm{Ti}$ & 1.901 & 0.031 & 1.411 & 0.124 & 1.899 & 0.020 & 1.467 & 0.029 & 1.743 & 0.007 \\
\hline $\mathrm{Ce}$ & 0.252 & 0.010 & 0.003 & 0.004 & 0.251 & 0.009 & 0.001 & 0.001 & 0.127 & 0.008 \\
\hline $\mathrm{Gd}$ & 0.220 & 0.010 & 0.000 & 0.000 & 0.210 & 0.007 & 0.001 & 0.000 & 0.214 & 0.020 \\
\hline $\mathrm{Hf}$ & 0.159 & 0.003 & 0.030 & 0.003 & 0.132 & 0.004 & 0.028 & 0.001 & 0.642 & 0.036 \\
\hline$\underline{U}$ & 0.369 & 0.023 & 0.001 & 0.000 & 0.390 & 0.030 & 0.001 & 0.001 & 0.204 & 0.016 \\
\hline $\begin{array}{l}\text { Catatoms } \\
\text { Oxygen }\end{array}$ & $\begin{array}{l}4.000= \\
6.678 \text {. }\end{array}$ & & $\begin{array}{l}3.000- \\
4.983 .\end{array}$ & & $\begin{array}{l}6.662- \\
4.000-\end{array}$ & & $\begin{array}{l}5.000- \\
3.000-\end{array}$ & & $\begin{array}{l}6.867- \\
4.000-\end{array}$ & \\
\hline Oxygen & $6.678-$ & & 4.983 . & & 4.000 - & & $3.000-$ & & $4.000-$ & \\
\hline $\mathrm{Ca}$ & 0.982 & & & & 1.017 & & & & 0.693 & \\
\hline Gd & 0.018 & & & & 0.000 & & & & 0.214 & \\
\hline $\operatorname{Ce}(+3)$ & 0.000 & & & & 0.000 & & & & 0.093 & \\
\hline Sum & 1.000 & & & & 1.017 & & & & 0.907 & \\
\hline Charge & 2.018 & & & & 2.035 & & & & 2.027 & \\
\hline $\mathrm{Ca}$ & 0.000 & & & & 0.000 & & & & 0.000 & \\
\hline $\mathrm{Al}$ & 0.000 & & 1.078 & & 0.000 & & 1.008 & & 0.000 & \\
\hline Mg & 0.091 & & 0.464 & & 0.081 & & 0.488 & & 0.162 & \\
\hline $\mathrm{Ce}(+3)$ & 0.252 & & 0.000 & & 0.251 & & 0.000 & & 0.033 & \\
\hline $\mathrm{Gd}$ & 0.202 & & 0.000 & & 0.210 & & 0.000 & & 0.000 & \\
\hline $\mathrm{Hf}$ & 0.086 & & 0.000 & & 0.051 & & 0.000 & & 0.601 & \\
\hline$U(+4)$ & 0.047 & & 0.000 & & 0.052 & & 0.000 & & 0.204 & \\
\hline$U(+6)$ & 0.322 & & 0.000 & & 0,338 & & 0.000 & & 0.000 & \\
\hline Sum & 1.000 & & 1.543 & & 0.983 & & 1.495 & & 1.000 & \\
\hline Charge & 4.009 & & 0.928 & & 3.985 & & 0.975 & & 3.643 & \\
\hline $\mathrm{Ti}$ & 1.901 & & 1.411 & & 1.899 & & 1.467 & & 1.743 & \\
\hline $\mathrm{Hf}$ & 0.073 & & 0.030 & & 0.081 & & 0.028 & & 0.041 & \\
\hline $\mathrm{Al}$ & 0.027 & & 0.000 & & 0.020 & & 0.000 & & 0.216. & \\
\hline Sum & 2.000 & & 1.442 & & 2.000 & & 1.495 & & 2.000 & \\
\hline Charge & 7.973 & & 5.766 & & 7.980 & & 5.978 & & 7.784 & \\
\hline Model Oxygen & 7.000 & & 4.965 & & 7.000 & & 4.989 & & 6.867 & \\
\hline
\end{tabular}


Table C12. Microprobe analyses of Ce-analog with 10 wt\% $\mathrm{CaAl}, \mathrm{O}$

\begin{tabular}{|c|c|c|c|c|c|c|c|c|c|c|c|c|c|c|c|c|}
\hline & $13-1$ & 1350 & $13-1$ & 1350 & $13-1$ & 1350 & $13-2$ & 1300 & $13-2$ & 1300 & $13-2$ & 1300 & $13-2$ & 1300 & $13-2$ & 1300 \\
\hline & $\begin{array}{c}\text { Pyrochlore } \\
w 1 \%\end{array}$ & std dev & $\begin{array}{l}\text { Hafnolite } \\
w 1 \%\end{array}$ & std dev & $\begin{array}{l}\text { CTA } \\
\text { w1\% }\end{array}$ & std dey & $\begin{array}{l}\text { Pyrochlore } \\
\text { wt\% }\end{array}$ & $\operatorname{std} d e y$ & Hafnolite & stc dev & CTA & std dev & Rutile & & Corundum & std dev \\
\hline $\mathrm{Al}, \mathrm{O}_{4}$ & 0.32 & 0.09 & 3.47 & 0.74 & 57.64 & 0.37 & 0.20 & 0.01 & $\begin{array}{r}-W 1 \% \\
3.73\end{array}$ & 0.17 & 57.64 & $\begin{array}{c}\mathrm{sedev} \\
0.37\end{array}$ & $\begin{array}{l}w \% \\
1.10\end{array}$ & stadev & $\begin{array}{r}\mathrm{wt} \% \\
99.08\end{array}$ & $\frac{\text { stddev }}{1.31}$ \\
\hline $\mathrm{CaO}$ & 14.78 & 0.17 & 11.37 & 0.94 & 5.86 & 0.08 & 14.84 & 0.09 & 11.04 & 0.15 & 5.86 & 0.08 & 0.22 & 0.01 & 0.08 & 0.05 \\
\hline TiO, & $36.4 \mathrm{I}$ & 0.39 & 37.01 & 0.63 & 30.36 & 0.10 & 35.93 & 0.19 & 36.74 & 0.29 & 30.36 & 0.10 & 87.43 & 0.45 & 0.30 & 0.11 \\
\hline $\mathrm{Ce}_{\mathrm{O}} \mathrm{O}_{2}$ & 8.50 & 0.17 & 3.62 & 1.23 & 5.33 & 0.13 & 8.75 & 0.23 & 2.98 & 0.31 & 5.33 & 0.13 & 0.08 & 0.04 & 0.06 & 0.01 \\
\hline $\mathrm{Gd}, \mathrm{O}_{2}$ & 7.79 & 0.19 & 6.54 & 0.53 & 0.87 & 0.06 & 7.81 & 0.21 & 6.52 & 0.24 & 0.87 & 0.06 & 0.06 & 0.04 & 0.02 & 0.03 \\
\hline Hfo, & 6.97 & 0.77 & 28.23 & 4.92 & 1.31 & 0.14 & 5.70 & 0.16 & 31.37 & 1.20 & 1.31 & 0.14 & 8.93 & 0.26 & 0.16 & 0.02 \\
\hline $\mathrm{UO}_{2}$ & 22.62 & 0.59 & 8.79 & 3.34 & 0.15 & 0.09 & 23.66 & 0.27 & 7.18 & 1.03 & 0.15 & 0.09 & 2.37 & 0.04 & 0.06 & 0.02 \\
\hline $\begin{array}{l}\text { Total } \\
\end{array}$ & 97.38 - & & 99.04 & & 101.52 & & $96.88-$ & & 99.55 & 0.52 & 101.52 & & 100.19 & & $09.76-$ & \\
\hline Al & 0.027 & 0.007 & 0.284 & 0.062 & 8.178 & 0.030 & 0.017 & 0.001 & 0.305 & 0.013 & 8.184 & 0.020 & 0018 & 0.000 & 1.993 & 0.002 \\
\hline $\mathrm{Ca}$ & 1.125 & 0.015 & 0.846 & 0.067 & 0.755 & 0.011 & 1.139 & 0.006 & 0.821 & 0.013 & $\begin{array}{l}8.184 \\
0.755\end{array}$ & 0.010 & 0.003 & $\begin{array}{l}0.000 \\
0.000\end{array}$ & $\begin{array}{l}1.993 \\
0.001\end{array}$ & $\begin{array}{l}0.002 \\
0.001\end{array}$ \\
\hline $\mathrm{Ti}$ & 1.945 & 0.012 & 1.932 & 0.015 & 2.748 & 0.015 & 1.936 & 0.008 & 1.917 & 0.013 & 2.757 & 0.017 & 0.934 & 0.001 & 0.004 & 0.001 \\
\hline $\mathrm{Ce}$ & 0.221 & 0.005 & 0.092 & 0.031 & 0.235 & 0.005 & 0.229 & 0.006 & 0.076 & 0.008 & 0.233 & 0.002 & 0.000 & 0.000 & 0.000 & 0.000 \\
\hline Gd & 0.183 & 0.005 & 0.151 & 0.012 & 0.035 & 0.002 & 0.185 & 0.005 & 0.150 & 0.006 & 0.034 & 0.002 & 0.000 & 0.000 & 0.000 & 0.000 \\
\hline Hf & 0.141 & 0.015 & 0.560 & 0.100 & 0.045 & 0.005 & 0.116 & 0.003 & 0.621 & 0.022 & 0.035 & 0.002 & 0.036 & 0.001 & 0.001 & 0.000 \\
\hline$\underline{U}$ & 0.358 & 0.011 & 0.136 & 0.051 & 0.004 & 0.002 & 0.377 & 0.003 & 0.111 & 0.016 & 0.004 & 0.001 & 0.007 & 0.000 & 0.000 & 0.000 \\
\hline Catatoms & 4.000 & 0.000 & 4.000 & 0.000 & 12.000 & 0.000 & 4.000 & 0.000 & 4.000 & 0.000 & 12.000 & 0.000 & 1.000 & 0.000 & 2.000 & 0.000 \\
\hline oxygen & 6.660 & 0.014 & 6.891 & 0.058 & 19.021 & 0.008 & 6.645 - & & 6.914 - & & & & 1.987. & & 3.002 - & \\
\hline $\begin{array}{ll}\mathrm{Ca} \\
\mathrm{Gd}\end{array}$ & 1.000 & & 0.846 & & & & 1.000 & & 0.821 & & & & & & & \\
\hline Sum & 1.000 & & 0.996 & & & & $\frac{0,000}{1.000}$ & & $\frac{0.150}{0.971}$ & & & & & & & \\
\hline Charge & 2.000 & & 2.143 & & & & 2.000 & & 2.091 & & & & & & & \\
\hline $\mathrm{Ca}$ & 0.125 & & 0.000 & & 0.755 & & 0.139 & & 0.000 & & 0.755 & & & & & \\
\hline $\mathrm{Ce}(+3)$ & 0.221 & & 0.092 & & 0.235 & & 0.229 & & 0.076 & & 0.233 & & & & & \\
\hline Gd & 0.183 & & 0.000 & & 0.035 & & 0.185 & & 0.000 & & 0.034 & & & & & \\
\hline $\mathrm{Hf}$ & 0.113 & & 0.560 & & 0.000 & & 0.106 & & 0.621 & & 0.000 & & & & & \\
\hline $\mathrm{U}(+4)$ & 0.018 & & 0.027 & & 0.004 & & 0.096 & & 0.025 & & 0.004 & & & & & \\
\hline $\mathrm{U}(+6)$ & 0.340 & & 0.109 & & 0.000 & & 0.281 & & 0.086 & & 0.000 & & & & & \\
\hline Sum & 1.000 & & 0.788 & & 1.029 & & 1.037 & & 0.808 & & 1.025 & & & & & \\
\hline Charge & 4.026 & & 3.276 & & 2.335 & & 4.016 & & 3.327 & & 2.323 & & & & & \\
\hline $\mathrm{Ti}$ & 1.945 & & 1.932 & & 2.748 & & 1.936 & & 1.917 & & 2.757 & & 0.934 & & & \\
\hline Hf & 0.028 & & 0.000 & & 0.045 & & 0.047 & & 0.000 & & 0.035 & & 0.080 & & & \\
\hline Al & 0,027 & & 0.284 & & 8.178 & & 0.017 & & 0.305 & & 8.184 & & 0.018 & & 1.993 & \\
\hline Sum & 2.000 & & 2.216 & & 10.972 & & 2.000 & & 2.222 & & 10.975 & & 2.000 & & 2.000 & \\
\hline Charge & 7.973 & & 8.581 & & 35.708 & & 7.983 & & 8.582 & & 35.718 & & 3.947 & & 3.947 & \\
\hline Model Oxygen & 7.000 & & 7.000 & & 19.022 & & 7.000 & & 7.000 & & 19.021 & & 2.055 & & 2.990 & \\
\hline
\end{tabular}


Table C!3. Mircoprobe compostions for Ce-analog with $\mathrm{MoO}$

\begin{tabular}{|c|c|c|c|c|c|c|}
\hline & P229 & 1350 & P229 & 1350 & P229 & 1350 \\
\hline & $\begin{array}{r}\text { Pyrochlore } \\
\text { wit\% } \\
\end{array}$ & & $\begin{array}{r}\text { Brannerite } \\
\text { wt } \%\end{array}$ & std dev & $\begin{array}{r}\text { Ca-Mo } \\
\text { wt\% }\end{array}$ & std dev \\
\hline $\mathrm{Al}_{2} \mathrm{O}_{2}$ & 0.00 & 0.00 & 0.00 & 0.00 & 0.00 & 0.00 \\
\hline $\mathrm{CaO}$ & 12.62 & 0.09 & 1.25 & 0.06 & 26.60 & 0.11 \\
\hline TiO, & 30.70 & 0.21 & 39.73 & 0.47 & 0.12 & 0.05 \\
\hline $\mathrm{MoO}_{2}$ & 1.73 & 0.13 & 0.08 & 0.04 & 70.21 & 0.39 \\
\hline $\mathrm{Ce}, \mathrm{O}_{3}$ & 7.38 & 0.10 & 9.02 & 0.33 & 0.92 & 0.03 \\
\hline $\mathrm{Gd}, \mathrm{O}_{2}$ & 9.85 & 0.38 & 8.17 & 0.16 & 0.81 & 0.04 \\
\hline $\mathrm{HfO}$, & 11.02 & 0.17 & 7.44 & 0.43 & 0.19 & 0.06 \\
\hline $\mathrm{UO}_{2}$ & 20.39 & 0.37 & 27.84 & 0.34 & 0.07 & 0.02 \\
\hline Total & 93.70 & & $93.53-$ & & 98.91 & \\
\hline Al & 0.000 & 0.000 & 0.000 & 0.000 & 0.000 & 0.000 \\
\hline $\mathrm{Ca}$ & 1.061 & 0.006 & 0.088 & 0.004 & 0.973 & 0.001 \\
\hline $\mathrm{Ti}$ & 1.812 & 0.010 & 1.966 & 0.011 & 0.003 & 0.001 \\
\hline Mo & 0.057 & 0.004 & 0.002 & 0.001 & 1.001 & 0.002 \\
\hline $\mathrm{Ce}$ & 0.212 & 0.003 & 0.217 & 0.008 & 0.011 & 0.000 \\
\hline $\mathrm{Gd}$ & 0.256 & 0.010 & 0.178 & 0.002 & 0.009 & 0.000 \\
\hline $\mathrm{Hf}$ & 0.247 & 0.003 & 0.140 & 0.009 & 0.002 & 0.001 \\
\hline$\underline{U}$ & 0.356 & 0.006 & 0.408 & 0.003 & 0.001 & 0.000 \\
\hline Catatoms & $\begin{array}{l}4.000- \\
6762-\end{array}$ & & $\begin{array}{l}3.000 \\
5716\end{array}$ & & $2.000-$ & \\
\hline Oxygen & $6.762-$ & & 5.716 - & & $4.017-$ & \\
\hline $\mathrm{Ca}$ & 1.000 & & & & & \\
\hline $\mathrm{Mo}+6)$ & 0.000 & & & & & \\
\hline Gd & 0.000 & & & & & \\
\hline $\mathrm{Ce}(+3)$ & 0.000 & & & & & \\
\hline$U(+4)$ & 0.000 & & & & & \\
\hline Sum & 1.000 & & & & & \\
\hline Charge & 2.000 & & & & & \\
\hline $\mathrm{Ca}$ & 0.061 & & 0.088 & & & \\
\hline $\mathrm{Mo}(+6)$ & 0.000 & & 0 & & 0 & \\
\hline $\mathrm{Ce}(+3)$ & 0.212 & & 0.217 & & 0.011 & \\
\hline $\mathrm{Gd}$ & 0.256 & & 0.178 & & 0.009 & \\
\hline $\mathrm{Hf}$ & 0.115 & & 0.108 & & 0.002 & \\
\hline$U(+4)$ & 0.118 & & 0.124 & & 0 & \\
\hline $\mathrm{U}(+6)$ & 0.238 & & 0.284 & & 0.001 & \\
\hline Sum & 1.000 & & 1.000 & & 0.996 & \\
\hline Charge & 3.173 & & 3.144 & & 2.017 & \\
\hline $\mathrm{Ti}$ & 1.812 & & 1.966 & & 0.003 & \\
\hline $\mathrm{HF}$ & 0.132 & & 0.031 & & 0 & \\
\hline Al & 0.000 & & 0.000 & & 0.000 & \\
\hline Mo( +6$)$ & 0.057 & & 0.002 & & $\begin{array}{l}1.001 \\
\end{array}$ & \\
\hline Sum & 2.000 & & 2.000 & & 1.004 & \\
\hline Charge & 7.774 & & 7.991 & & 0.013 & \\
\hline Model Oxygen & 7.000 & & 6.000 & & 4.018 & \\
\hline
\end{tabular}




\section{Table C14. Microprobe analyses of Ce-analog with WO,}

\begin{tabular}{|c|c|c|c|c|c|c|c|c|}
\hline & P232 & 1350 & $\mathrm{P} 232$ & 1350 & $\mathrm{P} 232$ & 1350 & P232 & 1350 \\
\hline & Pyrochlore & & B rannerite & & $\mathrm{Ca} \cdot \mathrm{w}$ & & Rutile & \\
\hline & & std der & & std dev & $\mathrm{wt} \%$ & std dev & wt & std dev \\
\hline $\mathrm{Al}_{2} \mathrm{O}_{3}$ & 0.00 & 0.00 & 0.00 & 0.00 & 0.00 & 0.00 & 0.05 & 0.01 \\
\hline $\mathrm{CaO}$ & 12.19 & 0.08 & 1.14 & 0.03 & 18.55 & 0.07 & 0.07 & $\begin{array}{l}0.01 \\
0.03\end{array}$ \\
\hline $\mathrm{TiO}_{2}$ & 26.90 & 0.29 & 39.01 & 0.36 & 0.27 & 0.05 & 67.53 & 0.64 \\
\hline $\mathrm{Ce}_{2} \mathrm{O}_{3}$ & 6.15 & 0.17 & 9.32 & 0.32 & 0.86 & 0.03 & 0.16 & 0.15 \\
\hline $\mathrm{Gd}_{2} \mathrm{O}_{3}$ & 8.09 & 0.19 & 8.64 & 0.14 & 0.84 & 0.03 & 0.14 & 0.06 \\
\hline $\mathrm{HfO}_{2}$ & 7.12 & 0.18 & 7.76 & 0.63 & 0.33 & 0.02 & 26.52 & 0.54 \\
\hline $\mathrm{WO}_{3}$ & 14.37 & 0.09 & 1.50 & 0.17 & 73.99 & 0.24 & 0.83 & 0.15 \\
\hline $\mathrm{UO}_{2}$ & 19.28 & 0.33 & 26.69 & 0.26 & 0.17 & 0.05 & 1.27 & 0.33 \\
\hline Total & 94.09 & & 94.05 . & & $95.01-$ & & 96.56 - & \\
\hline $\mathrm{Al}$ & 0.000 & 0.000 & 0.000 & 0.000 & 0.000 & 0.000 & 0.001 & 0.000 \\
\hline $\mathrm{Ca}$ & 1.083 & 0.008 & 0.081 & 0.002 & 0.994 & 0.003 & 0.001 & 0.000 \\
\hline $\mathrm{Ti}$ & 1.676 & 0.015 & 1.940 & 0.009 & 0.010 & 0.002 & 0.859 & 0.004 \\
\hline $\mathrm{Ce}$ & 0.187 & 0.005 & 0.226 & 0.007 & 0.016 & 0.001 & 0.001 & 0.001 \\
\hline $\mathrm{Gd}$ & 0.222 & 0.006 & 0.189 & 0.003 & 0.014 & 0.000 & 0.001 & 0.000 \\
\hline Hf & 0.168 & 0.004 & 0.146 & 0.013 & 0.005 & 0.000 & 0.128 & 0.002 \\
\hline w & 0.309 & 0.002 & 0.026 & 0.003 & 0.959 & 0.004 & 0.004 & 0.001 \\
\hline $\mathbf{U}$ & 0.355 & 0.005 & 0.393 & 0.001 & 0.002 & 0.001 & 0.005 & 0.001 \\
\hline Catatoms & 4.000 & & 3.000 . & & $2.000-$ & & 1.000 & \\
\hline Oxygen & 7.021 & & 5.737 & & 3.950 - & & 2.001 - & \\
\hline
\end{tabular}

$\begin{array}{ll}\mathrm{Ca} & 1.000\end{array}$

$\begin{array}{ll}\mathrm{W}(+6) & 0.000 \\ \mathrm{Gd} & 0.000 \\ \mathrm{Ce}(+3) & 0.000\end{array}$
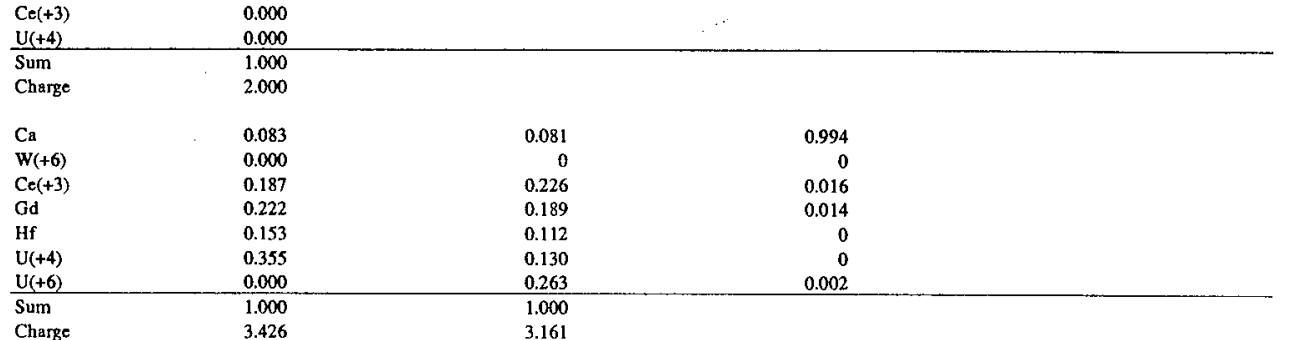

\begin{tabular}{lllll}
$\mathrm{Ti}$ & 1.676 & 1.940 & 0.010 & 0.859 \\
$\mathrm{Hf}$ & 0.015 & 0.035 & 0.005 & 0.128 \\
$\mathrm{Al}$ & 0.000 & 0.000 & 0.000 & 0.001 \\
$\mathrm{~W}(+6)$ & 0.309 & 0.026 & 0.999 & 0.004 \\
\hline Sum & 2.000 & 2.000 & 0.974 & 0.992 \\
Charge & 8.558 & 7.974 & 2.937 & 3.964 \\
& & & 3.952 & 1.987
\end{tabular}


Table C15. Microorobe analyses ( $\mathrm{w} t \%$ ) and structural formulae for the Ce-analog with $10 \mathrm{wt} \% \mathrm{P}, \mathrm{O}$, added

\begin{tabular}{|c|c|c|c|c|c|c|c|c|c|c|c|c|c|c|}
\hline & $2-1$ & $1300 \mathrm{C}$ & $2-1$ & $1300 \mathrm{C}$ & $2-1$ & $1300 \mathrm{C}$ & $2-1$ & $1300 \mathrm{C}$ & $2-2$ & $1400 \mathrm{C}$ & $2-2$ & $1400 \mathrm{C}$ & $2-2$ & $1400 \mathrm{C}$ \\
\hline & Brannerite & & Rutile & & Whitlockite & & P-Glass & & Brannerite & & Rutile & & P-Glass & \\
\hline $\mathrm{Al}, \mathrm{O}_{2}$ & wt\% & std dev & w1\% & std dev & $\mathrm{wt} \%$ & std dev & $\mathrm{wt} \%$ & std dev & $\mathbf{w t} \%$ & std dev & $w t \%$ & std dev & & std dev \\
\hline $\begin{array}{l}\mathrm{P}, \mathrm{O} \text {, } \\
\mathrm{P}\end{array}$ & 0.46 & 0.43 & 0.07 & $\begin{array}{l}0.01 \\
0.03\end{array}$ & $\begin{array}{r}0.00 \\
40.26\end{array}$ & 0.00 & $\begin{array}{r}0.00 \\
3677\end{array}$ & 0.00 & 0.00 & 0.00 & 0.00 & 0.00 & 0.01 & 0.02 \\
\hline $\mathrm{CaO}$ & 2.39 & 0.70 & 0.29 & 0.07 & 41.26 & $\begin{array}{l}0.94 \\
1.56\end{array}$ & $\begin{array}{l}30.11 \\
29.99\end{array}$ & $\begin{array}{l}2.30 \\
0.38\end{array}$ & $\begin{array}{l}0.00 \\
1.39\end{array}$ & 0.00 & 0.00 & 0.00 & $\begin{array}{l}37.96 \\
30.42\end{array}$ & 0.81 \\
\hline $\mathrm{TiO}$, & 40.63 & 2.00 & 72.82 & 1.49 & 1.60 & 2.17 & 0.74 & 0.19 & 40.72 & 0.58 & 69.52 & 0.65 & 0.21 & 0.30 \\
\hline $\mathrm{CeO}_{2}$ & 7.61 & 0.57 & 0.10 & 0.03 & 7.75 & 0.33 & 17.78 & 0.21 & 6.80 & 0.17 & 0.08 & 0.02 & 16.96 & 0.32 \\
\hline $\mathrm{Gd}, \mathrm{O}_{3}$ & 7.19 & 0.53 & 0.08 & 0.06 & 7.80 & 0.52 & 13.75 & 0.37 & 8.16 & 0.20 & 0.14 & 0.06 & 14.15 & 0.31 \\
\hline $\mathrm{HfO}_{2}$ & 7.79 & 0.39 & 26.09 & 1.58 & 0.30 & 0.31 & 0.31 & 0.12 & 8.77 & 0.36 & 29.15 & 0.61 & 0.32 & 0.13 \\
\hline $\mathrm{UO}_{2}$ & 31.65 & 1.66 & 1.33 & 0.25 & 1.10 & 1.22 & 0.36 & 0.18 & 31.42 & 0.64 & 1.41 & 0.07 & 0.24 & 0.16 \\
\hline Total & 97.74 - & & 100.85 & & $100.06-$ & & 99.70 & & 97.27 & & $100.36-$ & & 100.26 - & \\
\hline Al & 0.001 & 0.001 & 0.001 & 0.000 & 0.000 & 0.000 & 0.000 & 0.000 & 0.000 & 0.000 & 0.000 & 0.000 & 0.001 & 0.003 \\
\hline $\mathrm{P}$ & 0.024 & 0.023 & 0.001 & 0.000 & 4.805 & 0.084 & 4.162 & 0.164 & 0.000 & 0.000 & 0.000 & 0.000 & 4.248 & 0.047 \\
\hline $\mathrm{Ca}$ & 0.161 & 0.050 & 0.005 & 0.001 & 6.233 & 0.217 & 4.301 & 0.136 & 0.096 & 0.003 & 0.001 & 0.001 & 4.308 & 0.029 \\
\hline $\mathrm{Ti}$ & 1.916 & 0.073 & 0.869 & 0.009 & 0.170 & 0.231 & 0.074 & 0.018 & 1.968 & 0.008 & 0.856 & 0.004 & 0.021 & 0.006 \\
\hline $\mathrm{Ce}$ & 0.167 & 0.014 & 0.001 & 0.000 & 0.381 & 0.018 & 0.831 & 0.020 & 0.152 & 0.003 & 0.000 & 0.000 & 0.783 & 0.017 \\
\hline Gd & 0.150 & 0.012 & 0.000 & 0.000 & 0.365 & 0.023 & 0.610 & 0.026 & 0.174 & 0.004 & 0.001 & 0.000 & 0.620 & 0.015 \\
\hline Hf & 0.139 & 0.008 & 0.118 & 0.008 & 0.012 & 0.012 & 0.012 & 0.005 & 0.161 & 0.005 & 0.136 & 0.003 & 0.012 & 0.005 \\
\hline U & 0.442 & 0.021 & 0.005 & 0.001 & 0.034 & 0.038 & 0.011 & 0.006 & 0.449 & 0.004 & 0.005 & 0.000 & 0.007 & 0.005 \\
\hline Catatt & $3.000-$ & & $1.000-$ & & 12.000 & & 10.000 & & $3.000-$ & & 1.000 & & $10.000-$ & \\
\hline Oxyg & $5.776-$ & & $1.995-$ & & 19.987 & & 17.475 & - & $5.817-$ & & $1.999-$ & & $17.505-$ & \\
\hline
\end{tabular}

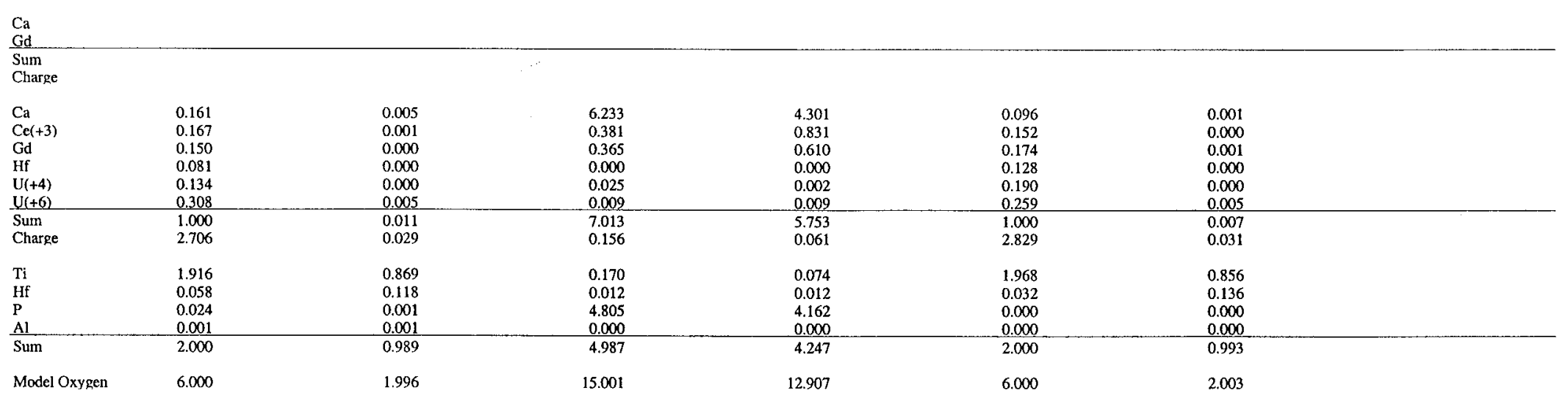


Table C15. Microprobe analyses $(w t \%)$ and structural formulae for the Ce-analog with $10 \mathrm{w} 1 \% \mathrm{P}, \mathrm{O}$, added

\begin{tabular}{|c|c|c|c|c|c|c|c|c|}
\hline & $2-3$ & $1350 \mathrm{C}$ & $2-3$ & $1350 \mathrm{C}$ & $2-3$ & $1350 \mathrm{C}$ & $2-3$ & $1350 \mathrm{C}$ \\
\hline & Brannerite & & Rutile & & whitlockite & & P-glass & \\
\hline & & std dev & wt $\%$ & sid dev & $\mathrm{wt} \%$ & stddev & & std dev \\
\hline $\mathrm{Al}_{2} \mathrm{O}_{2}$ & 0.01 & 0.01 & 0.00 & 0.00 & 0.00 & 0.00 & 0.00 & 0.00 \\
\hline $\mathrm{P}_{2}, \mathrm{O}_{4}$ & 0.24 & 0.59 & 0.12 & 0.11 & 40.95 & 1.02 & 37.40 & 2.05 \\
\hline $\mathrm{CaO}$ & 1.97 & 0.42 & 0.45 & 0.10 & 42.32 & 0.26 & 29.78 & 0.33 \\
\hline TiO, & 40.99 & 0.69 & 69.34 & 1.50 & 0.28 & 0.22 & 0.83 & 0.40 \\
\hline $\mathrm{CeO}$ & 6.53 & 0.58 & 0.27 & 0.15 & 7.15 & 0.46 & 17.23 & 0.90 \\
\hline $\mathrm{Gd}_{2} \mathrm{O}_{2}$ & 7.52 & 0.18 & 0.19 & 0.03 & 7.10 & 0.34 & 13.78 & 0.31 \\
\hline $\mathrm{HFO}$ & 8.08 & 0.53 & 28.70 & 0.65 & 0.06 & 0.10 & 0.47 & 0.04 \\
\hline UQ, & 32.41 & 1.24 & 1.77 & 0.83 & 0.27 & 0.24 & 0.20 & 0.19 \\
\hline Total & 97.75 . & & $100.84-$ & & 98.14 & & $99.69-$ & \\
\hline Al & 0.000 & 0.001 & 0.000 & 0.000 & 0.00 & 0.00 & 0.000 & \\
\hline P & 0.013 & 0.031 & 0.002 & 0.001 & 4.89 & 0.08 & 4.223 & 0.141 \\
\hline $\mathrm{Ca}$ & 0.133 & 0.028 & 0.008 & 0.002 & 6.39 & 0.07 & 4.258 & 0.094 \\
\hline $\mathrm{Ti}$ & 1.950 & 0.044 & 0.848 & 0.006 & 0.03 & 0.02 & 0.083 & 0.039 \\
\hline $\mathrm{Ce}$ & 0.144 & 0.012 & 0.002 & 0.001 & 0.35 & 0.02 & 0.803 & 0.050 \\
\hline Gd & 0.158 & 0.004 & 0.001 & 0.000 & 0.33 & 0.01 & 0.610 & 0.024 \\
\hline $\mathrm{Hf}$ & 0.146 & 0.010 & 0.133 & 0.004 & 0.00 & 0.00 & 0.018 & 0.002 \\
\hline U & 0.456 & 0.020 & 0.006 & 0.003 & 0.01 & 0.01 & 0.006 & 0.006 \\
\hline Catatoms & $3.000-$ & & $1.000-$ & & 12.00 & 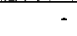 & $10.000-$ & \\
\hline Oxygen & 5.794 - & & $1.992-$ & & 19.89 & . & 17.548 - & \\
\hline
\end{tabular}

\begin{tabular}{llll}
$\begin{array}{l}\text { Ca } \\
\text { Gd }\end{array}$ & & \\
\hline Sum & & & \\
Charge & & & \\
Ca & 0.133 & 0.008 & 6.390 \\
Ce(+3) & 0.144 & 0.002 & 0.352 \\
Gd & 0.158 & 0.001 & 0.332 \\
Hf & 0.109 & 0.000 & 0.000 \\
U(+4) & 0.178 & 0.001 & 0.000 \\
U(+6) & 0.278 & 0.005 & 7.008 \\
\hline Sum & 1.000 & 0.017 & 0.050 \\
Charge & 2.816 & 0.036 & 0.030 \\
& 1.950 & 0.848 & 0.002 \\
Ti & 0.037 & 0.133 & 4.886 \\
Hf & 0.013 & 0.002 & 0.000 \\
P & 0.000 & 0.000 & 4.918 \\
Al & 2.000 & 0.983 & 19.89
\end{tabular}


Table C16. Microprobe analyses of $\mathrm{Ce}$-analog with $10 \mathrm{wt} \% \mathrm{SiO}$,

\begin{tabular}{|c|c|c|c|c|c|c|c|c|c|c|c|c|}
\hline & $10-1$ & 1350 & $10-1$ & 1350 & $10-1$ & 1350 & $10-2$ & 1300 & $10-2$ & 1300 & $10-2$ & 1300 \\
\hline & Brannerite & & Rutile & & Glass & & Brannerite & & Glass & & Hafnon & \\
\hline & $w t \%$ & std der & $w 1 \%$ & std dey & $\mathrm{wt} \%$ & std dev & wt\% & std dev & wt\% & std dev & wt & std dev \\
\hline$\overline{\mathrm{Al}_{2} \mathrm{O}_{2}}$ & 0.00 & 0.00 & 0.05 & 0.00 & 0.23 & 0.01 & 0.01 & 0.01 & 0.46 & 0.02 & 0.00 & 0.00 \\
\hline $\mathrm{SiO}_{2}$ & 0.00 & 0.00 & 0.00 & 0.00 & 15.21 & 0.07 & 0.00 & 0.00 & 24.88 & 0.50 & 16.57 & 1.75 \\
\hline $\mathrm{CaO}$ & 1.09 & 0.05 & 0.03 & 0.01 & 10.83 & 0.19 & 1.22 & 0.27 & 23.80 & 0.14 & 0.22 & 0.16 \\
\hline $\mathrm{TiO}$ & 40.55 & 0.27 & 73.18 & 0.65 & 32.40 & 0.20 & 40.64 & 0.32 & 32.95 & 0.34 & 1.75 & 1.49 \\
\hline $\mathrm{Ce}, \mathrm{O}_{3}$ & 8.46 & 0.19 & 0.03 & 0.03 & 7.96 & 0.09 & 10.38 & 0.32 & 0.84 & 0.09 & 1.09 & 0.56 \\
\hline $\mathrm{GdO}_{3}$ & 9.22 & 0.23 & 0.00 & 0.00 & 5.98 & 0.18 & 9.12 & 0.16 & 2.16 & 0.10 & 1.13 & 0.71 \\
\hline $\mathrm{HfO}$, & 9.25 & 0.27 & 25.27 & 0.45 & 8.99 & 0.15 & 6.66 & 0.59 & 12.21 & 0.75 & 73.28 & 3.99 \\
\hline UO, & 29.53 & 0.38 & 0.98 & 0.07 & $\begin{array}{r}15.07 \\
\end{array}$ & 0.39 & 28.14 & $\begin{array}{l}0.80 \\
\end{array}$ & 0.19 & 0.02 & $\begin{array}{l}1.99 \\
\end{array}$ & 1.57 \\
\hline Total & 98.11 & & $99.54-$ & & 96.65 & & $96.17-$ & & $97.50-$ & & 96.03 & \\
\hline $\mathrm{Al}$ & 0.000 & 0.000 & 0.001 & 0.000 & 0.043 & 0.001 & 0,001 & 0,000 & 0.068 & 0,003 & 0.000 & 0000 \\
\hline $\mathrm{Si}$ & 0.000 & 0.000 & 0.000 & 0.000 & 2.443 & 0.013 & 0.000 & 0.000 & 3.100 & 0.044 & 0.411 & 0.035 \\
\hline $\mathrm{Ca}$ & 0.074 & 0.003 & 0.000 & 0.000 & 1.864 & 0.032 & 0.084 & 0.019 & 3.178 & 0.028 & 0.006 & 0.004 \\
\hline $\mathrm{Ti}^{\mathrm{i}}$ & 1.945 & 0.009 & 0.880 & 0.002 & 3.914 & 0.022 & 1.956 & 0.012 & 3.088 & 0.028 & 0.033 & 0.029 \\
\hline $\mathrm{Ce}$ & 0.198 & 0.005 & 0.000 & 0.000 & 0.468 & 0.005 & 0.243 & 0.007 & 0.038 & 0.004 & 0.010 & 0.005 \\
\hline $\mathrm{Gd}$ & 0.195 & 0.005 & 0.000 & 0.000 & 0.318 & 0.009 & 0.194 & 0.004 & 0.089 & 0.004 & 0.009 & 0.006 \\
\hline $\mathrm{Hf}$ & 0.169 & 0.006 & 0.115 & 0.002 & 0.412 & 0.008 & 0.122 & 0.011 & 0.435 & 0.028 & 0.519 & 0.019 \\
\hline u & 0.419 & 0.004 & 0.003 & 0.000 & 0.539 & 0.013 & 0.401 & 0.010 & 0.005 & 0.001 & 0.011 & 0.009 \\
\hline Cata & $3.000-$ & & 1.000 & 0.000 & 10.000 & 0.000 & 3.000 & 0.000 & 10.000 & 0.000 & 1.000 & 0.000 \\
\hline Oxy & 5.729 & & 1.999 & & 17.722 & & 5.697 & & 16.725 & & 1.984 & \\
\hline
\end{tabular}

$\mathrm{Ca}$

\begin{tabular}{|c|c|c|c|c|c|c|}
\hline $\begin{array}{l}\text { Sum } \\
\text { Charge }\end{array}$ & & & & & & \\
\hline $\mathrm{Ca}$ & 0.074 & & 1864 & 0.084 & 3.178 & \\
\hline $\mathrm{Ce}(+3)$ & 0.198 & & $\begin{array}{l}0.468 \\
0.048\end{array}$ & $\begin{array}{l}0.084 \\
0.243\end{array}$ & 0.038 & \\
\hline $\mathrm{Gd}$ & 0.195 & & $\begin{array}{l}0.318 \\
0.318\end{array}$ & $\begin{array}{l}0.243 \\
0.194\end{array}$ & $\begin{array}{l}0.038 \\
0.089\end{array}$ & \\
\hline Hf & 0.114 & & $\begin{array}{l}0.418 \\
0.412\end{array}$ & $\begin{array}{l}0.194 \\
0.079\end{array}$ & $\begin{array}{l}0.089 \\
0.435\end{array}$ & \\
\hline$U(+4)$ & 0.170 & & 0.539 & 0.152 & 0.005 & \\
\hline$U(+6)$ & $\begin{array}{r}0.249 \\
\end{array}$ & & 0.000 & $\begin{array}{l}0.132 \\
0.249\end{array}$ & 0.000 & \\
\hline Sum & $\frac{1.2000}{1.000}$ & & 3.600 & $\frac{0.647}{1.000}$ & 3.745 & \\
\hline Charge & 4.000 & & 4.000 & 4.000 & 4.000 & \\
\hline $\mathrm{Ti}$ & 1.945 & 0.880 & 3.914 & 1.956 & 3.088 & 0.033 \\
\hline $\mathrm{Hf}$ & 0.055 & 1.119 & 0.000 & 0.043 & 0.000 & 1.967 \\
\hline $\mathrm{Al}$ & 0.000 & 0.001 & 0.043 & 0.001 & 0.068 & 0.000 \\
\hline Si & 0.000 & 0.000 & 2.443 & 0.000 & 3.100 & 0.411 \\
\hline Sum & 2.000 & 2.000 & $\frac{2.403}{2.000}$ & 2.000 & $\frac{3.100}{2.000}$ & \\
\hline Charge & 7.992 & 7.992 & 7.992 & 7.992 & 7.992 & 7.992 \\
\hline Madel Oxygens & 5.978 & 4.000 & & 5.946 & & 4.000 \\
\hline
\end{tabular}


Table C17. Microprobe analyses of Ce-analog with $10 \mathrm{wt} \% \mathrm{NaAlSiO}$

\begin{tabular}{|c|c|c|c|c|c|c|c|c|c|c|c|c|c|c|}
\hline 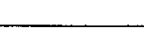 & 15.1 & 1350 & $15-1$ & 1350 & $15-1$ & 1350 & $15-2$ & 1300 & $15-2$ & 1300 & $15-2$ & 1300 & $15-2$ & 1300 \\
\hline & Pyrochlore & & Hafnolite & & Glass & & Pyrochlore & & Hafnolite & & Rutile & & glass & \\
\hline & & std dev & $\mathrm{wt} \%$ & std dev. & $w+\%$ & std dev & wt\% & std dev & $\mathrm{w} t \%$ & std dev. & wt\% & std dev & wt\% & std dev \\
\hline $\mathrm{Na}, \mathrm{O}$ & 0.99 & 0.07 & 0.56 & 0.04 & 4.01 & 0.39 & 1.04 & 0.07 & 0.71 & 0.07 & 0.02 & 0.03 & 4.77 & 0.76 \\
\hline $\mathrm{Al}_{1} \mathrm{O}_{2}$ & 0.15 & 0.04 & 2.59 & 0.19 & 8.79 & 1.53 & 0.11 & 0.01 & 2.66 & 0.42 & 0.69 & 0.02 & 19.24 & 0.85 \\
\hline $\mathrm{SiO}$ & 0.05 & 0.01 & 0.57 & 0.06 & 15.43 & 2.60 & 0.01 & 0.02 & 0.72 & 0.27 & 0.22 & 0.03 & 35.25 & 1.42 \\
\hline $\mathrm{CaO}$ & 11.24 & 0.13 & 8.85 & 0.19 & 6.39 & 1.19 & 11.61 & 0.09 & 9.39 & 0.36 & 0.09 & 0.02 & 6.32 & 0.29 \\
\hline TiO, & 33.70 & 0.20 & 33.57 & 0.26 & 42.94 & 3.72 & 34.08 & 0.22 & 34.91 & 0.40 & 80.66 & 0.40 & 22.98 & 1.97 \\
\hline $\mathrm{Ce}_{2} \mathrm{O}_{2}$ & 9.16 & 0.11 & 3.52 & 0.34 & 4.00 & 1.16 & 9.69 & 0.16 & 3.84 & 0.87 & 0.06 & 0.01 & 1.08 & 0.33 \\
\hline $\mathrm{Gd}, \mathrm{O}$ & 9.99 & 0.22 & 7.73 & 0.07 & 1.77 & 1.23 & 9.07 & 0.22 & 7.21 & 0.26 & 0.12 & 0.06 & 0.41 & 0.28 \\
\hline $\mathrm{HfO}_{2}$ & 10.26 & 0.42 & 34.23 & 1.75 & 5.94 & 0.88 & 7.90 & 0.21 & 32.97 & 3.92 & 14.84 & 0.14 & 3.09 & 0.24 \\
\hline UO, & .23 .17 & 0.33 & 7.57 & 1.16 & 9.99 & 2.90 & 24.81 & 0.21 & 8.27 & 2.39 & 2.04 & 0.09 & 5.55 & 1.00 \\
\hline Total & 98.71 - & & 99.19 - & & 99.27 & & $98.32-$ & & $100.67-$ & & $98.72-$ & 0.07 & $98.69-$ & 1.61 \\
\hline $\mathrm{Na}$ & 0.141 & 0.010 & 0.080 & 0.006 & 0.987 & 0.051 & 0.148 & 0.009 & 0.098 & 0.009 & 0.000 & 0.001 & 0.982 & 0.133 \\
\hline Al & 0.013 & 0.004 & 0.223 & 0.016 & 1.309 & 0.158 & 0.010 & 0.001 & 0.222 & 0.033 & 0.012 & 0.000 & $\begin{array}{l}2.416 \\
2.416\end{array}$ & 0.087 \\
\hline $\mathrm{Si}$ & 0.004 & 0.001 & 0.041 & 0.004 & 1.950 & 0.226 & 0.001 & 0.001 & 0.050 & 0.019 & 0.003 & 0.000 & 3.756 & 0.116 \\
\hline $\mathrm{Ca}$ & 0.888 & 0.007 & 0.693 & 0.015 & 0.881 & 0.219 & 0.912 & 0.005 & 0.711 & 0.034 & 0.001 & 0.000 & 0.722 & 0.043 \\
\hline $\mathrm{Ti}$ & 1.868 & 0.011 & 1.844 & 0.018 & 4.100 & 0.197 & 1.879 & 0.010 & 1.856 & 0.019 & 0.911 & 0.001 & 1.842 & 0.165 \\
\hline $\mathrm{Ce}$ & 0.247 & 0.003 & 0.094 & 0.009 & 0.190 & 0.067 & 0.260 & 0.004 & 0.100 & 0.024 & 0.000 & 0.000 & 0.042 & 0.014 \\
\hline Gd & 0.244 & 0.005 & 0.187 & 0.002 & 0.078 & 0.059 & 0.220 & 0.005 & 0.169 & 0.008 & 0.001 & 0.000 & 0.015 & 0.010 \\
\hline $\mathrm{Hf}$ & 0.216 & 0.009 & 0.714 & 0.033 & 0.218 & 0.046 & 0.165 & 0.004 & 0.665 & 0.074 & 0.064 & 0.000 & 0.094 & 0.009 \\
\hline$\underline{U}$ & 0.380 & 0.005 & 0.123 & 0.019 & 0.288 & 0.102 & 0.405 & 0.003 & 0.130 & 0.039 & 0.007 & 0.000 & 0.132 & 0.026 \\
\hline $\begin{array}{l}\text { Catatoms } \\
\text { oxygen }\end{array}$ & $\begin{array}{l}4.000- \\
6.648-\end{array}$ & & $\begin{array}{l}4.000- \\
6.935=\end{array}$ & & $\begin{array}{l}10.000- \\
16.851-\end{array}$ & & $\begin{array}{l}4.000- \\
6.621\end{array}$ & & $\begin{array}{l}4.000- \\
6.897=\end{array}$ & & $\begin{array}{l}1.000- \\
1.991-\end{array}$ & & $\begin{array}{l}10.000- \\
16.569-\end{array}$ & \\
\hline $\mathrm{Na}$ & 0.141 & & 0.080 & & & & 0.148 & & 0.098 & & & & & \\
\hline $\mathrm{Ca}$ & 0.888 & & & & & & 0.912 & & 0.711 & & & & & \\
\hline Gd & 0.000 & & 0.187 . & & & & 0.000 & & 0.169 & & & & & \\
\hline Sum & 1.029 & & 0.960 & & & & 1.060 & & 0.978 & & & & & \\
\hline Charge & 1.917 & & 2.028 & & & & 1.972 & & 2.027 & & & & & \\
\hline $\mathrm{Ca}$ & 0.000 & & 0.000 & & & & 0.000 & & 0.000 & & & & & \\
\hline Al & 0.000 & & 0.068 & & & & & & 0.077 & & & & & \\
\hline $\mathrm{Ce}(+3)$ & 0.247 & & 0.094 & & & & 0.260 & & 0.100 & & & & & \\
\hline Gd & 0.244 & & 0.000 & & & & 0.220 & & 0.000 & & & & & \\
\hline $\mathrm{Hf}$ & 0.096 & & 0.714 & & & & 0.054 & & 0.665 & & & & & \\
\hline$U(+4)$ & 0.021 & & 0.000 & & & & 0.025 & & 0.000 & & & & & \\
\hline$U(+6)$ & 0.359 & & 0.123 & & & & 0.380 & & 0.130 & & & & & \\
\hline Sum & 0.967 & & 0.999 & & & & 0.939 & & 0.972 & & & & & \\
\hline Charge & 3.020 & & 3.507 & & & & 2.897 & & 3.349 & & & & & \\
\hline $\mathrm{Ti}$ & 1.868 & & 1.844 & & & & 1.879 & & 1.856 & & 0.911 & & & \\
\hline Hf & 0.120 & & 0.000 & & & & 0.111 & & 0.000 & & 0.064 & & & \\
\hline Al & 0.013 & & 0.156 & & & & 0.010 & & 0.145 & & 0.012 & & & \\
\hline Sum & 2.000 & & 2.000 & & & & 2.000 & & 2.000 & & 0.987 & & & \\
\hline Charge & 7.987 & & 7.844 & & & & 7.990 & & 7.856 & & 3.936 & & & \\
\hline Model Oxygen & 7.000 & & 6.976 & & & & 7.000 & & 6.927 & & 1.968 & & & \\
\hline
\end{tabular}


Table C18. Microprobe analyses of $\mathrm{Ce}$-analog with $20 \mathrm{wt} \% \mathrm{NaAlSiO}_{1}$

\begin{tabular}{|c|c|c|c|c|c|c|c|c|c|c|c|c|}
\hline & $16-1$ & 1350 & $16-1$ & 1350 & $16-1$ & 1350 & $16-2$ & 1300 & $16-2$ & 1300 & $16-2$ & 1300 \\
\hline & Pyrochlore & & Glass & & Hafnolite & add dev & Pyrochlore & & Hafnolite & & Glass & std dey \\
\hline $\mathrm{Na}, \mathrm{O}$ & $\begin{array}{l}-w 6 \% \\
1.12\end{array}$ & $\frac{0.08}{0.08}$ & $\frac{\mathrm{w} t \%}{4.67}$ & $\frac{\mathrm{sedev}}{0.44}$ & $\frac{w t \%}{0.66}$ & $\frac{s i d \text { dev }}{0.10}$ & $\frac{w t \%}{1.26}$ & $\begin{array}{r}\text { std dev } \\
0.07\end{array}$ & $\frac{w+\%}{0.95}$ & $\begin{array}{r}\text { std dev } \\
0.11\end{array}$ & $\frac{w 1 \%}{6.36}$ & $\begin{array}{r}\text { std dev } \\
0.89\end{array}$ \\
\hline $\mathrm{Al}, \mathrm{O}$, & 0.11 & 0.01 & 9.72 & 0.30 & 2.49 & 0.17 & 0.10 & 0.01 & 2.91 & 0.80 & 15.27 & 0.49 \\
\hline $\mathrm{SiO}$ & 0.08 & 0.01 & 17.18 & 0.31 & 0.58 & 0.07 & 0.09 & 0.07 & 2.09 & 1.81 & 27.93 & 0.80 \\
\hline $\mathrm{CaO}$ & 10.55 & 0.11 & 7.41 & 0.24 & 8.61 & 0.24 & 10.98 & 0.11 & 8.81 & 0.16 & 4.80 & 0.67 \\
\hline TiO, & 31.97 & 0.24 & 33.01 & 0.50 & 31.71 & 0.18 & 34.47 & 0.21 & 35.82 & 0.60 & 29.80 & 0.74 \\
\hline $\mathrm{Ce}_{2} \mathrm{O}_{3}$ & 9.77 & 0.21 & 4.32 & 0.23 & 3.56 & 0.56 & 10.11 & 0.20 & 3.08 & 0.21 & 1.60 & 0.38 \\
\hline $\mathrm{GdO}_{2}$ & 10.90 & 0.22 & 2.52 & 0.31 & 8.13 & 0.42 & 9.43 & 0.22 & 6.81 & 0.38 & 1.00 & 0.27 \\
\hline HFO, & 11.67 & 0.31 & 6.46 & 0.16 & 35.50 & 2.18 & 7.88 & 0.20 & 34.16 & 1.84 & 3.63 & 0.27 \\
\hline $\mathrm{UO}_{2}$ & 21.71 & 2.06 & 12.54 & 0.44 & 7.27 & 1.48 & 23.31 & 0.25 & 6.05 & 0.40 & 7.88 & 0.80 \\
\hline Total & 97.88 & 1.90 & 97.83 & 0.65 & 98.50 & 0.96 & 97.64 - & & $100.69-$ & & $98.26-$ & \\
\hline $\mathrm{Na}$ & 0.163 & 0.013 & 1.167 & 0.098 & 0.096 & 0.015 & 0.179 & 0.009 & 0.127 & 0.015 & 1.374 & 0.155 \\
\hline $\mathrm{Al}$ & 0.010 & 0.001 & 1.479 & 0.037 & 0.219 & 0.015 & 0.009 & 0.001 & 0.234 & 0.057 & 2.010 & 0.042 \\
\hline $\mathrm{Si}$ & 0.006 & 0.001 & 2.217 & 0.029 & 0.043 & 0.005 & 0.006 & 0.005 & 0.141 & 0.117 & 3.121 & 0.055 \\
\hline $\mathrm{Ca}$ & 0.852 & 0.005 & 1.024 & 0.037 & 0.688 & 0.014 & 0.862 & 0.008 & 0.649 & 0.026 & 0.574 & 0.075 \\
\hline $\mathrm{Ti}$ & 1.812 & 0.013 & 3.203 & 0.056 & 1.780 & 0.005 & 1.899 & 0.010 & 1.853 & 0.079 & 2.506 & 0.103 \\
\hline $\mathrm{Ce}$ & 0.270 & 0.006 & 0.204 & 0.012 & 0.097 & 0.015 & 0.271 & 0.005 & 0.078 & 0.007 & 0.066 & 0.016 \\
\hline $\mathrm{Gd}$ & 0.272 & 0.006 & 0.108 & 0.014 & 0.201 & 0.010 & 0.229 & 0.005 & 0.155 & 0.013 & 0.037 & 0.010 \\
\hline Hf & 0.251 & 0.008 & 0.238 & 0.008 & 0.756 & 0.046 & 0.165 & 0.004 & 0.671 & 0.053 & 0.116 & 0.011 \\
\hline$\underline{U}$ & 0.364 & 0.033 & 0.360 & 0.016 & 0.121 & 0.024 & 0.380 & 0.005 & 0.093 & 0.007 & 0.196 & 0.023 \\
\hline $\begin{array}{l}\text { Catatoms } \\
\text { oxygen }\end{array}$ & $\begin{array}{l}4.000= \\
6.628=\end{array}$ & & $\begin{array}{l}10.000- \\
16.330-\end{array}$ & & $\begin{array}{l}4.000- \\
6.910-\end{array}$ & & $\begin{array}{l}4.000- \\
6.615-\end{array}$ & & $\begin{array}{l}4.000- \\
6.928 \text { - }\end{array}$ & & $\begin{array}{l}10.000 \\
16.308-\end{array}$ & \\
\hline $\mathrm{Na}$ & 0.163 & & & & 0.096 & & 0.179 & & 0.127 & & & \\
\hline $\mathrm{Ca}$ & 0.852 & & & & 0.688 & & 0.862 & & 0.649 & & & \\
\hline Gd & 0.000 & & & & 0.201 & & 0.000 & & 0.155 & & & \\
\hline Sum & 1.015 & & & & 0.985 & & 1.041 & & 0.931 & & & \\
\hline Charge & 1.867 & & & & 2.075 & & 1.903 & & 1.890 & & & \\
\hline $\mathrm{Ca}$ & 0.000 & & & & 0.000 & & 0.000 & & 0.000 & & & \\
\hline $\mathrm{Al}$ & 0.000 & & & & 0.000 & & 0.000 & & 0.000 & & & \\
\hline $\mathrm{Ce}(+3)$ & 0.270 & & & & 0.097 & & 0.271 & & 0.078 & & & \\
\hline $\mathrm{Gd}$ & 0.272 & & & & 0.000 & & 0.229 & & 0.000 & & & \\
\hline $\mathrm{Hf}$ & 0.073 & & & & 0.756 & & 0.072 & & 0.671 & & & \\
\hline$U(+4)$ & 0.000 & & & & 0.000 & & 0.000 & & 0.000 & & & \\
\hline$U(+6)$ & 0.364 & & & & 0.121 & & 0.380 & & 0.093 & & & \\
\hline Sum & 0.979 & & & & 0.974 & & 0.952 & & 0.841 & & & \\
\hline Charge & 3.010 & & & & 3.678 & & 2.929 & & 3.195 & & & \\
\hline $\mathrm{Ti}$ & 1.812 & & & & 1.780 & & 1.899 & & 1.853 & & & \\
\hline $\mathrm{Hf}$ & 0.178 & & & & 0.000 & & 0.093 & & 0.000 & & & \\
\hline $\mathrm{Al}$ & 0.010 & & & & 0.219 & & 0.009 & & 0.234 & & & \\
\hline Sum & 2.000 & & & & 1.998 & & 2.000 & & 2.087 & & & \\
\hline Charge & 7.990 & & & & 7.774 & & 7.991 & & 8.113 & & & \\
\hline Model Oxygen & 6.979 & & & & 6.945 & & 6.982 & & 6.738 & & & \\
\hline
\end{tabular}


Table C19. Microprobe analyses of Ce-analog with $10 \mathrm{wt} \% \mathrm{CaO}$

\begin{tabular}{|c|c|c|c|c|c|c|c|c|c|c|c|c|}
\hline & $9-1$ & 1300 & $9-1$ & 1300 & $9-2$ & 1400 & $9-2$ & 1400 & $9-3$ & 1350 & $9-3$ & 1350 \\
\hline & $\begin{array}{r}\text { Pyrochlore } \\
\text { wt\% }\end{array}$ & std dev & $\begin{array}{r}\text { Perovskite } \\
\text { wt } \%\end{array}$ & std dev & $\begin{array}{r}\text { Pyrochlore } \\
\text { wt } \%\end{array}$ & & $\begin{array}{r}\text { Perovskite } \\
\text { wt\% }\end{array}$ & & $\begin{array}{l}\text { Pyrochlore } \\
\text { wt \% }\end{array}$ & std dev & $\begin{array}{l}\text { Perovskite } \\
\text { wt\% }\end{array}$ & std dev \\
\hline $\mathrm{Al}, \mathrm{O}$ & 0.03 & 0.01 & 0.53 & 0.14 & 0.00 & 0.00 & $\frac{1.00}{0.00}$ & 0.00 & 0.03 & 0.01 & 0.46 & 0.07 \\
\hline $\mathrm{CaO}$ & 14.51 & 0.31 & 33.26 & 0.51 & 15.05 & 0.14 & 32.17 & 0.20 & 14.44 & 0.46 & 32.38 & 0.51 \\
\hline TiO, & 26.93 & 1.01 & 53.85 & 0.63 & 27.99 & 0.36 & 54.49 & 0.24 & 26.88 & 1.07 & 53.66 & 0.32 \\
\hline $\mathrm{CeO}$ & 7.70 & 0.22 & 5.07 & 0.68 & 7.38 & 0.10 & 6.37 & 0.55 & 7.28 & 0.41 & 6.07 & 0.44 \\
\hline $\mathrm{Gd}, \mathrm{O}$, & 7.27 & 0.22 & 6.75 & 0.79 & 7.61 & 0.13 & 5.62 & 0.93 & 7.34 & 0.20 & 5.76 & 0.55 \\
\hline $\mathrm{HfO}$ & 15.65 & 2.43 & 1.27 & 0.30 & 13.33 & 0.81 & 0.69 & 0.41 & 17.08 & 2.71 & 1.66 & 0.75 \\
\hline $\mathrm{UO}_{2}$ & 25.51 & 0.95 & 0.25 & 0.06 & 26.84 & 0.29 & 0.02 & 0.04 & 24.60 & 1.88 & 0.09 & 0.10 \\
\hline Total & 97.61 - & & 100.98 . & & 98.19 - & & $99.36-$ & & $97.64-$ & & 100.09 & \\
\hline $\mathrm{Al}$ & 0.003 & 0.001 & 0.016 & 0.004 & 0.000 & 0.000 & 0.000 & 0.000 & 0.003 & 0.001 & 0.014 & 0.002 \\
\hline $\mathrm{Ca}$ & 1.205 & 0.009 & 0.876 & 0.009 & 1.236 & 0.006 & 0.863 & 0.004 & 1.205 & 0.024 & 0.865 & 0.009 \\
\hline $\mathrm{Ti}$ & 1.580 & 0.038 & 0.997 & 0.007 & 1.614 & 0.015 & 1.026 & 0.004 & 1.580 & 0.037 & $\begin{array}{l}1.006 \\
000\end{array}$ & 0.010 \\
\hline $\mathrm{Ce}$ & 0.210 & 0.004 & 0.046 & 0.006 & 0.207 & 0.003 & 0.058 & 0.005 & 0.210 & 0.014 & 0.055 & 0.004 \\
\hline Gd & 0.192 & 0.004 & 0.054 & 0.006 & 0.194 & 0.004 & 0.047 & 0.008 & 0.192 & 0.008 & 0.048 & 0.004 \\
\hline $\mathrm{Hf}$ & 0.385 & 0.059 & 0.009 & 0.002 & 0.292 & 0.018 & 0.005 & 0.003 & 0.385 & 0.063 & 0.012 & 0.005 \\
\hline$\underline{U}$ & 0.425 & 0.011 & 0.001 & 0.000 & 0.458 & 0.005 & 0.000 & 0.000 & 0.425 & 0.027 & 0.001 & 0.001 \\
\hline $\begin{array}{l}\text { Catatoms } \\
\text { Oxygen }\end{array}$ & $\begin{array}{l}4.090 \\
6.593-\end{array}$ & 0.000 & $\begin{array}{l}2.000 \\
3.066 \text { - }\end{array}$ & 0.000 & $\begin{array}{l}4.000- \\
6.564-\end{array}$ & & $\begin{array}{l}2.000- \\
3.084\end{array}$ & & $\begin{array}{l}4.000 \\
6.593 .\end{array}$ & 0.000 & $\begin{array}{l}2.000 \\
3.077\end{array}$ & 0.000 \\
\hline $\begin{array}{l}\mathrm{Ca} \\
\mathrm{Gd}\end{array}$ & $\begin{array}{l}1.000 \\
0.000\end{array}$ & & & & $\begin{array}{l}1.000 \\
0.000 \\
\end{array}$ & & & & $\begin{array}{l}1.000 \\
0.000\end{array}$ & & & \\
\hline Sum & 1.000 & & & & 1.000 & & & & 1.000 & & & \\
\hline Charge & 2.000 & & & & 2.000 & & & & 2.000 & & & \\
\hline $\mathrm{Ca}$ & 0.205 & & 0.876 & & 0.236 & & 0.863 & & 0.205 & & 0.865 & \\
\hline $\mathrm{Ce}(+3)$ & 0.210 & & 0.046 & & 0.207 & & 0.058 & & 0.210 & & 0.055 & \\
\hline Gd & 0.192 & & 0.054 & & 0.194 & & 0.047 & & 0.192 & & 0.048 & \\
\hline $\mathrm{Hf}$ & 0.106 & & 0.009 & & 0.106 & & 0.005 & & 0.106 & & 0.012 & \\
\hline $\mathrm{U}(+4)$ & 0.294 & & 0.001 & & 0.422 & & 0.000 & & 0.294 & & 0.001 & \\
\hline $\mathrm{U}(+6)$ & 0.131 & & 0.000 & & 0.036 & & 0.000 & & 0.131 & & 0.000 & \\
\hline Sum & 1.031 & & 0.987 & & 1.031 & & 0.974 & & 1.031 & & 0.980 & \\
\hline Charge & 4.000 & & 2.097 & & 4.000 & & 2.062 & & 4.000 & & 2.088 & \\
\hline $\mathrm{Ti}$ & 1.580 & & 0.997 & & 1.614 & & 1.026 & & 1.580 & & 1.006 & \\
\hline Hf & 0.417 & & 0.000 & & 0.386 & & 0.000 & & 0.418 & & 0.000 & \\
\hline Al & 0.003 & & 0.016 & & 0,000 & & 0.000 & & 0.003 & & 0.014 & \\
\hline Sum & 2.000 & & 1.013 & & 2.000 & & 1.026 & & 2.000 & & 1.020 & \\
\hline Charge & 7.992 & & 4.035 & & 7.992 & & 4.106 & & 7.992 & & 4.065 & \\
\hline Model Oxygen & 7.000 & & 3.066 & & 7.000 & & 3.084 & & 7.000 & & 3.077 & \\
\hline
\end{tabular}


Table $\mathrm{C} 20$ Microprobe analyses (wt\%) and structural formulae for the Ce-analog with 10wt\% $\mathrm{CaF}_{2}$

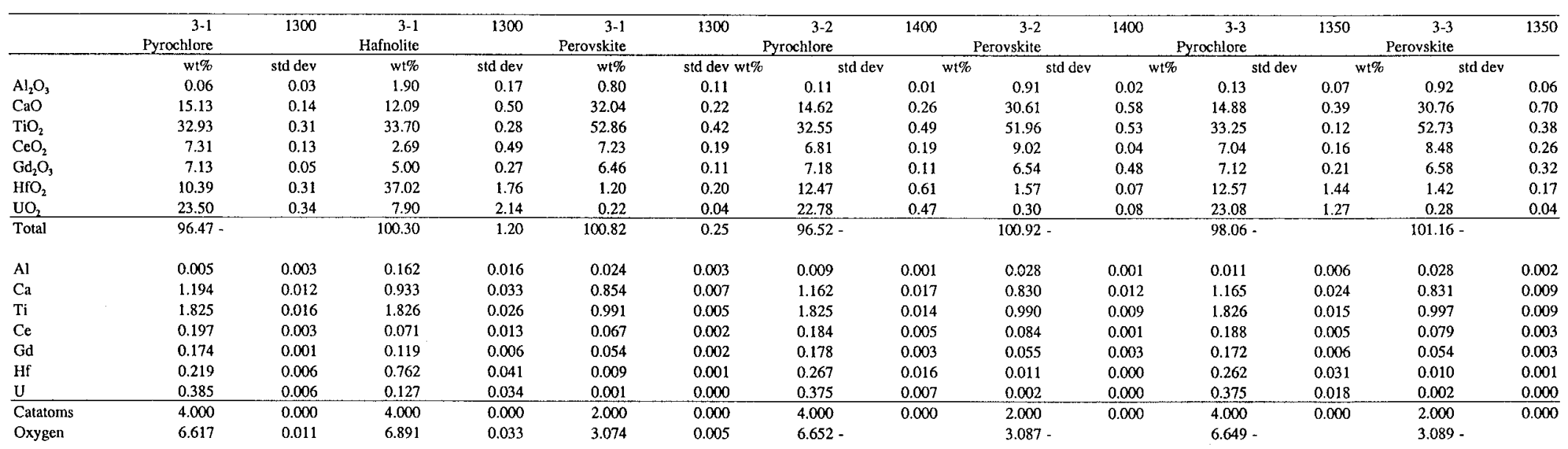

\begin{tabular}{|c|c|c|c|c|}
\hline $\begin{array}{l}\mathrm{Ca} \\
\mathrm{Gd} \\
\end{array}$ & $\begin{array}{l}1.000 \\
0.000\end{array}$ & $\begin{array}{l}0.933 \\
0.067\end{array}$ & $\begin{array}{l}1.000 \\
0.000\end{array}$ & $\begin{array}{l}1.000 \\
0.000\end{array}$ \\
\hline Sum & 1.000 & 1.000 & 1.000 & 1.000 \\
\hline Charge & 2.000 & 2.067 & 2.000 & 2.0 \\
\hline
\end{tabular}

\begin{tabular}{|c|c|c|c|c|c|c|c|}
\hline $\mathrm{Ca}$ & 0.194 & 0.000 & 0.854 & 0.162 & 0.830 & 0.165 & 0.831 \\
\hline $\mathrm{Ce}(+3)$ & 0.197 & 0.071 & 0.067 & 0.184 & 0.084 & 0.188 & 0.079 \\
\hline Gd & 0.174 & 0.053 & 0.054 & 0.178 & 0.055 & 0.172 & 0.054 \\
\hline Hf & 0.106 & 0.750 & 0.009 & 0.106 & 0.011 & 0.106 & 0.010 \\
\hline $\mathrm{U}(+4)$ & 0.117 & 0.018 & 0.001 & 0.038 & 0.002 & 0.037 & 0.002 \\
\hline $\mathrm{U}(+6)$ & 0.268 & 0.109 & 0.000 & 0.337 & 0.000 & 0.338 & 0.000 \\
\hline Sum & 1.057 & 1.000 & 0.985 & 1.005 & 0.982 & 1.031 & 0.976 \\
\hline Charge & 4.004 & 4.094 & 2.110 & 4.009 & 2.129 & 4.011 & 2.108 \\
\hline $\mathrm{Ti}$ & 1.825 & 1.826 & 0.991 & 1.825 & 0.990 & 1.826 & 0.997 \\
\hline Hf & 0.170 & 0.012 & 0.000 & 0.166 & 0.000 & 0.163 & 0.000 \\
\hline $\mathrm{Al}$ & 0.005 & 0.162 & 0.024 & 0.009 & 0.028 & 0.011 & 0.028 \\
\hline Sum & 2.000 & 2.000 & 1.015 & 2.000 & 1.018 & 2.000 & 1.024 \\
\hline Charge & 7.995 & 7.838 & 4.038 & 7.991 & 4.044 & 7.989 & 4.070 \\
\hline Model Oxygen & 7.000 & 7.000 & 3.074 & 7.000 & 3.087 & 7.000 & 3.089 \\
\hline
\end{tabular}


Table C21. Microprobe analyses of Ce-analog with $10 \mathrm{wt} \% \mathrm{MnO}_{2}$

\begin{tabular}{|c|c|c|c|c|c|c|c|c|}
\hline & $20-1$ & 1350 & $20-1$ & 1350 & $20-2$ & 1300 & $20-2$ & 1300 \\
\hline & Pvrochlore & & Perovskite & & Pyrochlore & & Perovskite & \\
\hline & & std dev & $w t \%$ & $s i d d v$ & $w t \%$ & $s t d d v$ & & std dev \\
\hline $\mathrm{Al}_{1} \mathrm{O}_{2}$ & 0.12 & 0.01 & 0.79 & 0.05 & 0.16 & 0.00 & 0.89 & 0.05 \\
\hline $\mathrm{CaO}$ & 9.16 & 0.06 & 29.39 & 0.24 & 9.35 & 0.08 & 29.62 & 0.25 \\
\hline TiO, & 33.66 & 0.10 & 51.15 & 0.43 & 33.85 & 0.13 & 51.13 & 0.23 \\
\hline $\mathrm{MnO}$ & 7.36 & 0.21 & 4.74 & 0.08 & 7.52 & 0.16 & 5.33 & 0.10 \\
\hline $\mathrm{Ce}_{2} \mathrm{O}_{2}$ & 6.93 & 0.11 & 5.12 & 0.16 & 7.25 & 0.22 & 4.33 & 0.14 \\
\hline $\mathrm{Gd}, \mathrm{O}_{2}$ & 7.75 & 0.18 & 7.73 & 0.30 & 7.58 & 0.17 & 7.82 & 0.17 \\
\hline HFO, & 10.64 & 0.30 & 1.26 & 0.07 & 10.40 & 0.19 & 1.06 & 0.10 \\
\hline $\mathrm{UQ}_{2}$ & 20.54 & 0.27 & 0.15 & 0.04 & 20.14 & 0.29 & 0.20 & 0.04 \\
\hline Total & 96.14 . & & 100.32 & & 96.24 - & & 100.37 . & \\
\hline Al & 0.010 & 0.001 & 0.023 & 0.002 & 0.014 & 0.000 & 0.026 & 0.001 \\
\hline $\mathrm{Ca}$ & 0.724 & 0.006 & 0.790 & 0.004 & 0.733 & 0.007 & 0.791 & 0.004 \\
\hline $\mathrm{Ti}$ & 1.868 & 0.008 & 0.965 & 0.004 & 1.863 & 0.006 & 0.958 & 0.004 \\
\hline $\mathrm{Mn}$ & 0.460 & 0.011 & 0.101 & 0.002 & 0.466 & 0.008 & 0.113 & 0.002 \\
\hline $\mathrm{Ce}$ & 0.187 & 0.003 & 0.047 & 0.002 & 0.194 & 0.005 & 0.040 & 0.001 \\
\hline Gd & 0.189 & 0.004 & 0.064 & 0.003 & 0.184 & 0.004 & 0.065 & 0.001 \\
\hline $\mathrm{Hf}$ & 0.224 & 0.006 & 0.009 & 0.000 & 0.217 & 0.004 & 0.008 & 0.001 \\
\hline u & 0.337 & 0.005 & 0.001 & 0.000 & 0.328 & 0.005 & 0.001 & 0.000 \\
\hline Cata & $4.000-$ & & 2.000 & & $4.000-$ & & $2.000-$ & \\
\hline Oxy & $6.623-$ & & $3.042-$ & & 6.605 - & & $3.032-$ & \\
\hline
\end{tabular}

\begin{tabular}{|c|c|c|c|c|}
\hline $\mathrm{Ca}$ & 0.724 & & 0.733 & \\
\hline Gd & 0.189 & & 0.184 & \\
\hline $\mathrm{Ce}(+3)$ & 0.087 & & 0.083 & \\
\hline$U( \pm 4)$ & 0.000 & & 0.000 & \\
\hline Sum & $\frac{1.000}{1.000}$ & & 1.000 & \\
\hline Charge & 2.276 & & 2.267 & \\
\hline $\mathrm{Ca}$ & 0.000 & 0.790 & 0.000 & 0.791 \\
\hline Mn & 0.460 & 0.101 & 0.466 & 0.113 \\
\hline $\mathrm{Ce}(+3)$ & 0.100 & 0.047 & 0.111 & 0.040 \\
\hline $\mathrm{Gd}$ & 0.000 & 0.064 & 0.000 & 0.065 \\
\hline $\mathrm{Hf}$ & 0.102 & 0.000 & 0.094 & 0.000 \\
\hline $\mathrm{U}(+4)$ & 0.000 & & 0.000 & \\
\hline $\begin{array}{r}(+4) \\
U(+6)\end{array}$ & 0.337 & 0.001 & 0.328 & 0.001 \\
\hline$\frac{U(1+0)}{\text { Sum }}$ & 1.000 & 1.003 & $\frac{1.320}{1.000}$ & 1.008 \\
\hline Charge & 2.643 & 2.118 & 2.628 & 2.120 \\
\hline $\mathrm{Ti}$ & 1.868 & 0.965 & 1.863 & 0.958 \\
\hline $\mathrm{Hf}$ & 0.122 & 0.009 & 0.123 & 0.008 \\
\hline $\mathrm{Al}$ & 0.010 & 0.023 & 0.014 & \\
\hline Sum & 2.000 & 0.997 & 2.000 & 0.992 \\
\hline Charge & 7.990 & 3.966 & 7.986 & 3.942 \\
\hline Model Oxygen & 6.960 & 3.043 & 6.933 & 3.033 \\
\hline
\end{tabular}


Table C22. Microprobe Analyses of Ce-analog with $10 \mathrm{wt} \% \mathrm{Gd}_{2} \mathrm{O}_{3}$

\begin{tabular}{|c|c|c|c|c|c|c|c|c|c|c|c|c|}
\hline & $14-1$ & 1350 & $14-1$ & 1350 & $14-1$ & -1350 & $14-2$ & 1300 & $.14-2$ & 1300 & $14-2$ & 1300 \\
\hline & Pyrochlore & & Brannerite & & Rutile & & Pyrochlore & & Brannerite & & Rutile & \\
\hline & & std dev. & $w t \%$ & std dev & $\mathrm{wt} \%$ & std dev & $w t \%$ & std dev & $\mathrm{wt} \%$ & std dev & w1\% & std dev \\
\hline $\mathrm{Al}_{\mathrm{A}, \mathrm{O}_{2}}$ & 0.07 & 0.01 & 0.27 & 0.02 & 0.39 & 0.04 & 0.06 & 0.01 & 0.28 & 0.09 & 0.33 & 0.04 \\
\hline $\mathrm{CaO}$ & 11.35 & 0.05 & 0.98 & 0.05 & 0.09 & 0.04 & 12.00 & 0.11 & 1.09 & 0.20 & 0.11 & 0.05 \\
\hline TiO, & 33.21 & 0.28 & 40.94 & 0.25 & 80.75 & 2.51 & 33.54 & 0.65 & 41.02 & 0.60 & 79.19 & 1.35 \\
\hline $\mathrm{Ce}, \mathrm{O}_{3}$ & 6.81 & 0.21 & 7.32 & 0.31 & 0.11 & 0.01 & 7.13 & 0.36 & 7.28 & 0.97 & 0.09 & 0.02 \\
\hline $\mathrm{Gd}_{2} \mathrm{O}_{2}$ & 16.62 & 0.47 & 11.31 & 0.31 & 0.26 & 0.09 & 17.01 & 0.28 & 11.87 & 0.29 & 0.11 & 0.10 \\
\hline $\mathrm{HFO}$, & 9.88 & 0.34 & 6.15 & 0.53 & 17.37 & 1.85 & 10.13 & 0.76 & 5.40 & 0.61 & 18.83 & 1.39 \\
\hline Uo, & 19.29 & 0.26 & 30.19 & 0.42 & 1.93 & 0.40 & 20.02 & 0.67 & 30.11 & 0.42 & 1.62 & 0.13 \\
\hline Total & 97.23 & & 97.15 & & 100.88 & & $99.89-$ & & $97.05-$ & & 100.28 & \\
\hline Al & 0.007 & 0.001 & 0.020 & 0.002 & 0.007 & 0.001 & 0.005 & 0.001 & 0.021 & 0.007 & 0.006 & 0.001 \\
\hline $\mathrm{Ca}$ & 0.930 & 0.004 & 0.067 & 0.003 & 0.001 & 0.001 & 0.957 & 0.012 & 0.074 & 0.014 & 0.002 & 0.001 \\
\hline $\mathrm{Ti}$ & 1.908 & 0.012 & 1.963 & 0.005 & 0.909 & 0.012 & 1.877 & 0.023 & 1.961 & 0.014 & 0.904 & 0.008 \\
\hline $\mathrm{Ce}$ & 0.191 & 0.006 & 0.171 & 0.007 & 0.001 & 0.000 & 0.194 & 0.010 & 0.169 & 0.021 & 0.000 & 0.000 \\
\hline Gd & 0.421 & 0.011 & 0.239 & 0.007 & 0.001 & 0.000 & 0.420 & 0.006 & 0.250 & 0.007 & 0.001 & 0.001 \\
\hline $\mathrm{Hf}$ & 0.216 & 0.008 & 0.112 & 0.009 & 0.074 & 0.009 & 0.215 & 0.015 & 0.098 & 0.012 & 0.082 & 0.007 \\
\hline $\mathrm{U}$ & 0.328 & 0.004 & 0.428 & 0.007 & 0.006 & 0.001 & 0.332 & 0.013 & 0.426 & 0.008 & 0.005 & 0.000 \\
\hline Catatoms & 4.000 & 0.000 & $\begin{array}{l}3.000 \\
571\end{array}$ & 0.000 & 1.000 & 0.000 & 4.000 & 0.000 & 3.000 & 0.000 & 1.000 & 0.000 \\
\hline oxygen & $6.761-$ & & $5.718-$ & & 1.994 & & 6.733 - & & $5.706-$ & & 1.995 . & \\
\hline $\begin{array}{l}\mathrm{Ca} \\
\mathrm{Gd}\end{array}$ & $\begin{array}{l}0.930 \\
0.070\end{array}$ & & & & & & $\begin{array}{l}0.957 \\
0.043\end{array}$ & & & & & \\
\hline Sum & 1.000 & & & & & & 1.000 & & & & & \\
\hline Charge & 2.070 & & & & & & 2.043 & & & & & \\
\hline $\mathrm{Ca}$ & 0.000 & & 0.146 & & 0.001 & & 0.000 & & 0146 & & & \\
\hline $\mathrm{Ce}(+3)$ & 0.191 & & $\begin{array}{l}0.140 \\
0.171\end{array}$ & & 0.001 & & 0.194 & & $\begin{array}{l}0.140 \\
0.169\end{array}$ & & & \\
\hline $\mathrm{Gd}$ & 0.351 & & 0.157 & & 0.001 & & 0.377 & & 0.157 & & & \\
\hline $\mathrm{Hf}$ & 0.106 & & 0.095 & & -0.006 & & 0.106 & & 0.080 & & & \\
\hline$U(+4)$ & 0.039 & & 0.103 & & 0.000 & & 0.083 & & 0.065 & & & \\
\hline $\begin{array}{r}U(+6) \\
\end{array}$ & 0.289 & & 0.325 & & 0.006 & & $\begin{array}{l}0.249 \\
0.249\end{array}$ & & 0.361 & & & \\
\hline Sum & 0.975 & & 1.042 & & 1.042 & & 1.009 & & 1.042 & & & \\
\hline Charge & 3.937 & & 4.005 & & 4.005 & & 3.961 & & 4.005 & & & \\
\hline $\mathrm{Ti}$ & 1.908 & & 1.963 & & 0.909 & & 1.877 & & 1.961 & & 0.904 & \\
\hline $\mathrm{Hf}$ & 0.085 & & 0.017 & & 0.080 & & 0.118 & & 0.018 & & 0.080 & \\
\hline Al & 0.007 & & 0.020 & & 0.007 & & 0.005 & & 0.021 & & 0.006 & \\
\hline Sum & 2.000 & & 2.000 & & 2.000 & & 2.000 & & 2.000 & & 2.000 & \\
\hline Charge & 7.993 & & 7.970 & & 3.947 & & 7.995 & & 7.970 & & 3.947 & \\
\hline Total Oxygen & 7.000 & & 6.000 & & 2.000 & & 7.000 & & 6.000 & & 1.977 & \\
\hline
\end{tabular}


Table C23. Microprobe analyses of Ce-analog with $10 \mathrm{wt} \% \mathrm{Ga}_{2} \mathrm{O}_{3}$

\begin{tabular}{|c|c|c|c|c|c|c|c|c|c|c|c|c|}
\hline & $19-1$ & 1350 & $19-1$ & 1350 & $12-1$ & 1350 & $19-2$ & 1300 & $19-2$ & 1300 & 19.2 & 1300 \\
\hline & $\begin{array}{l}\text { Pyrochlore } \\
\text { wt } \%\end{array}$ & & Hafnolite & & Galonite & & Pyrochlore & & Hafnolite & & "Galonite" & \\
\hline$\overline{\mathrm{Al}}, \mathrm{O}_{2}$ & 0.01 & 0.01 & $\begin{array}{l}\mathrm{Wr} \% \\
0.24\end{array}$ & sider & $\begin{array}{l}1.6 \\
1.16\end{array}$ & $\frac{s t a d e r}{0.02}$ & $\begin{array}{l}\mathrm{wc} \% \\
0.04\end{array}$ & $\frac{-3 t d \mathrm{dev}}{0.01}$ & 0.30 & $\frac{\text { std dev }}{0.01}$ & 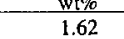 & 0.04 \\
\hline $\mathrm{CaO}$ & 14.25 & 0.11 & 8.18 & 0.09 & 7.21 & 0.20 & 15.04 & 0.13 & 8.40 & 0.15 & 7.67 & 0.11 \\
\hline $\mathrm{TiO}_{2}$ & 34.45 & 0.18 & 35.54 & 0.99 & 40.81 & 0.35 & 34.88 & 0.50 & 34.71 & 0.61 & 33.72 & 0.31 \\
\hline $\mathrm{Ga}_{2} \mathrm{O}_{3}$ & 2.14 & 0.13 & 12.96 & 0.24 & 34.89 & 0.68 & 2.36 & 0.12 & 14.68 & 0.19 & 41.28 & 0.37 \\
\hline $\mathrm{Ce}_{2} \mathrm{O}_{2}$ & 9.51 & 0.37 & 5.30 & 0.25 & 5.82 & 0.29 & 10.44 & 0.84 & 5.90 & 0.19 & 4.76 & 0.17 \\
\hline $\mathrm{Gd}, \mathrm{O}_{2}$ & 8.84 & 0.26 & 10.31 & 0.34 & 0.95 & 0.09 & 6.90 & 0.21 & 9.17 & 0.55 & 2.34 & 0.08 \\
\hline $\mathrm{HfO}$ & 4.76 & 0.13 & 19.14 & 0.67 & 0.70 & 0.10 & $\begin{array}{r}3.10 \\
2680\end{array}$ & 0.17 & 17.26 & $\begin{array}{l}0.46 \\
0.58\end{array}$ & 3.53 & 0.09 \\
\hline$\frac{\mathrm{UO}_{2}}{\text { Total }}$ & $\begin{array}{r}26.25 \\
100.20\end{array}$ & 0.18 & $\frac{8.29}{99.95}$ & 0.58 & $\begin{array}{r}7.24 \\
98.78-\end{array}$ & 0.53 & $\frac{26.80}{99.56-}$ & 0.98 & $\frac{10.67}{101.09-}$ & 0.58 & $\frac{3.88}{98.80-}$ & 0.11 \\
\hline $\mathrm{Al}$ & 0001 & 0001 & 0.020 & 0001 & 0.082 & 0901 & 0.003 & 0.001 & 0.025 & 0.001 & 0115 & \\
\hline $\mathrm{Ca}$ & 1.087 & 0.009 & 0.618 & 0.007 & 0.465 & 0.012 & 1.134 & 0.010 & 0.627 & 0.009 & 0.496 & 0.007 \\
\hline $\mathrm{Ti}$ & 1.845 & 0.004 & 1.883 & 0.030 & 1.849 & 0.016 & 1.845 & 0.014 & 1.820 & 0.024 & 1.529 & 0.011 \\
\hline $\mathrm{Ga}$ & 0.097 & 0.006 & 0.586 & 0.007 & 1.347 & 0.024 & 0.106 & 0.006 & 0.656 & 0.010 & 1.596 & 0.015 \\
\hline $\mathrm{Ce}$ & 0.248 & 0.009 & 0.137 & 0.005 & 0.128 & 0.007 & 0.269 & 0.020 & 0.151 & 0.004 & 0.105 & 0.003 \\
\hline $\mathrm{Gd}$ & 0.209 & 0.006 & 0.241 & 0.008 & 0.019 & 0.002 & 0.161 & 0.005 & 0.212 & 0.012 & 0.047 & 0.002 \\
\hline $\mathrm{Hf}$ & 0.097 & 0.003 & 0.385 & 0.018 & 0.012 & 0.002 & 0.062 & 0.004 & 0.344 & 0.010 & 0.061 & 0.002 \\
\hline$\underline{U}$ & 0.416 & 0.003 & 0.130 & 0.010 & 0.097 & 0.007 & 0.420 & 0.018 & 0.166 & 0.010 & 0.052 & 0.002 \\
\hline $\begin{array}{l}\text { Catatoms } \\
\text { Oxyouen }\end{array}$ & $\begin{array}{l}4.000- \\
6635-\end{array}$ & & $4.000-$ & & $\begin{array}{l}4.000- \\
6.746-\end{array}$ & & $\begin{array}{l}4.000- \\
6.597-\end{array}$ & & $\begin{array}{l}4.000- \\
6851-\end{array}$ & & $\begin{array}{l}4.000- \\
6573-\end{array}$ & \\
\hline & 6.635 - & & $6.890-$ & & & & & & $6.851-$ & & $6.3 / 3$ & \\
\hline $\mathrm{Ca}$ & 1.000 & & 0.618 & & 0.465 & & 1.000 & & 0.627 & & 0.496 & \\
\hline $\mathrm{Ga}$ & 0.000 & & 0.000 & & 0.290 & & 0.000 & & 0.000 & & 0.252 & \\
\hline Gd & 0.000 & & 0.241 & & 0.019 & & 0.000 & & 0.212 & & 0.047 & \\
\hline $\mathrm{Ce}(+3)$ & 0.000 & & 0.137 & & 0.128 & & 0.000 & & 0.151 & & 0.105 & \\
\hline$\frac{U(+4)}{c}$ & 0.000 & & 0.000 & & 0.097 & & 0,000 & & 0.000 & & 0.052 & \\
\hline Sum & 1.000 & & 0.996 & & 1.000 & & 1.000 & & 0.990 & & 0.951 & \\
\hline Charge & 2.000 & & 2.369 & & 1.761 & & 2.000 & & 2.343 & & 1.655 & \\
\hline $\mathrm{Ca}$ & 0.087 & & 0.000 & & 0.000 & & 0.134 & & 0.000 & & 0.000 & \\
\hline $\mathrm{Ga}$ & 0.040 & & 0.586 & & 1.000 & & 0.017 & & 0.656 & & 1.000 & \\
\hline $\mathrm{Ce}(+3)$ & 0.248 & & 0.000 & & 0.000 & & 0.269 & & 0.000 & & 0.000 & \\
\hline Gd & 0.209 & & 0.000 & & 0.000 & & 0.161 & & 0.000 & & 0.000 & \\
\hline Hf & 0.000 & & 0.289 & & 0.000 & & 0.000 & & 0.188 & & 0.000 & \\
\hline $\mathrm{U}(+4)$ & 0.051 & & 0.020 & & 0.000 & & 0.017 & & 0.017 & & 0.000 & \\
\hline $\mathrm{U}(+6)$ & 0.365 & & 0.110 & & 0.000 & & 0.403 & & 0.149 & & 0.000 & \\
\hline Sum & 1.000 & & 1.004 & & 1.000 & & 1.000 & & 1.010 & & 1.000 & \\
\hline Charge & 2.964 & & 3.322 & & 3.000 & & 2.883 & & 3.235 & & 3.000 & \\
\hline $\mathrm{Ti}$ & 1.845 & & 1.883 & & 1.849 & & 1.845 & & 1.820 & & 1.529 & \\
\hline Hf & 0.097 & & 0.097 & & 0.012 & & 0.062 & & 0.155 & & 0.012 & \\
\hline $\mathrm{Al}$ & 0.001 & & 0.020 & & 0.082 & & 0.003 & & 0.025 & & 0.115 & \\
\hline $\begin{array}{l}\mathrm{Al} \\
\mathrm{G}_{2}\end{array}$ & 0.057 & & 0.000 & & 0.057 & & 0.089 & & 0.000 & & 0.344 & \\
\hline Sum & 2.000 & & 2.000 & & 2.000 & & 2.000 & & 2.000 & & 2.000 & \\
\hline Charge & 7.770 & & 7.980 & & 7.690 & & 7.639 & & 7.975 & & 6.510 & \\
\hline Model Oxygen & 7.000 & & 7.000 & & 6.746 & & 7.000 & & 7.000 & & 6.476 & \\
\hline
\end{tabular}


Table C24. Mircoprobe analyses of Ce-Analog with $\mathrm{Nb}_{2} \mathrm{O}_{3}$

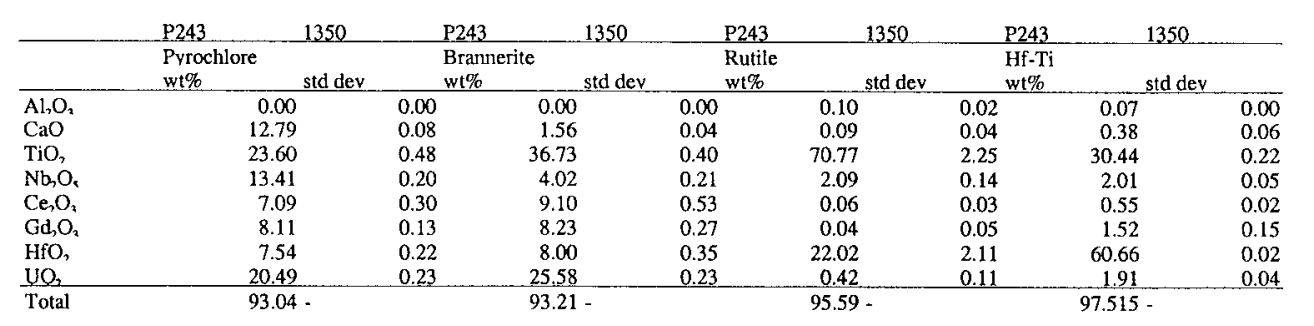

\begin{tabular}{lllllllll}
$\mathrm{Al}$ & 0.000 & 0.000 & 0.000 & 0.000 & 0.002 & 0.000 & 0.004 & 0.000 \\
$\mathrm{Ca}$ & 1.107 & 0.012 & 0.111 & 0.003 & 0.002 & 0.001 & 0.019 & 0.003 \\
$\mathrm{Ti}$ & 1.434 & 0.020 & 1.836 & 0.009 & 0.875 & 0.012 & 1.071 & 0.007 \\
$\mathrm{Nb}$ & 0.490 & 0.008 & 0.121 & 0.006 & 0.016 & 0.001 & 0.042 & 0.001 \\
$\mathrm{Ce}$ & 0.210 & 0.008 & 0.221 & 0.012 & 0.000 & 0.000 & 0.009 & 0.000 \\
$\mathrm{Gd}$ & 0.217 & 0.002 & 0.181 & 0.006 & 0.000 & 0.000 & 0.024 & 0.002 \\
$\mathrm{Hf}$ & 0.174 & 0.005 & 0.152 & 0.006 & 0.104 & 0.011 & 0.811 & 0.000 \\
$\mathrm{U}$ & 0.368 & 0.005 & 0.378 & 0.004 & 0.002 & 0.000 & 0.020 & 0.000 \\
\hline Catatoms & $4.000-$ & & $3.000-$ & & $1.000-$ & & $2.000-$ & \\
Oxygen & $6.924-$ & & $5.748-$ & & $2.005-$ & & $3.984-$
\end{tabular}

\begin{tabular}{|c|c|c|c|c|}
\hline $\begin{array}{l}\mathrm{Ca} \\
\mathrm{Gd}\end{array}$ & $\begin{array}{l}1.000 \\
0.000\end{array}$ & & & \\
\hline $\begin{array}{l}\text { Su } \\
\text { Sum } \\
\text { Charpe }\end{array}$ & $\begin{array}{l}0.000 \\
1.000 \\
2000\end{array}$ & & & \\
\hline $\mathrm{Ca}$ & 0.107 & 0111 & & 0010 \\
\hline Ti & 0.000 & 0.000 & & 0.071 \\
\hline $\mathrm{Nb}$ & 0.000 & 0.000 & & 0.042 \\
\hline $\mathrm{Ce}(+3)$ & 0.210 & 0.221 & & 0.009 \\
\hline $\mathrm{Gd}$ & 0.217 & 0.181 & & 0.024 \\
\hline $\mathrm{Hf}$ & 0.097 & 0.108 & & 0.811 \\
\hline $\mathrm{U}(+4)$ & 0.349 & 0.315 & & 0.015 \\
\hline $\mathrm{U}(+6)$ & 0.019 & 0.063 & & 0.005 \\
\hline Summ & 1.000 & $\frac{0.000}{1.00}$ & & $\frac{0.995}{0.995}$ \\
\hline Charge & 3.397 & 3.502 & & 3.468 \\
\hline $\mathrm{Ti}$ & 1.434 & 1.836 & 0.875 & 1.000 \\
\hline $\mathrm{Hf}$ & $\begin{array}{l}1.434 \\
0.076\end{array}$ & $\begin{array}{l}1.030 \\
0.044\end{array}$ & $\begin{array}{l}0.15 \\
1.107\end{array}$ & $\begin{array}{l}1.000 \\
0.000\end{array}$ \\
\hline $\mathrm{Nb}$ & 0.490 & 0.121 & 0.016 & 0.000 \\
\hline $\mathrm{Al}$ & 0.000 & 0.000 & 0.002 & 0.004 \\
\hline Sum & 2.000 & 2.000 & $\frac{0.000}{2.000}$ & 1.004 \\
\hline Charge & 8.490 & 8.121 & 8.014 & 4.011 \\
\hline Model Oxygens & 7.000 & 6.000 & 4.007 & 4.002 \\
\hline
\end{tabular}

